Latvijas Universitātes Žurnāls
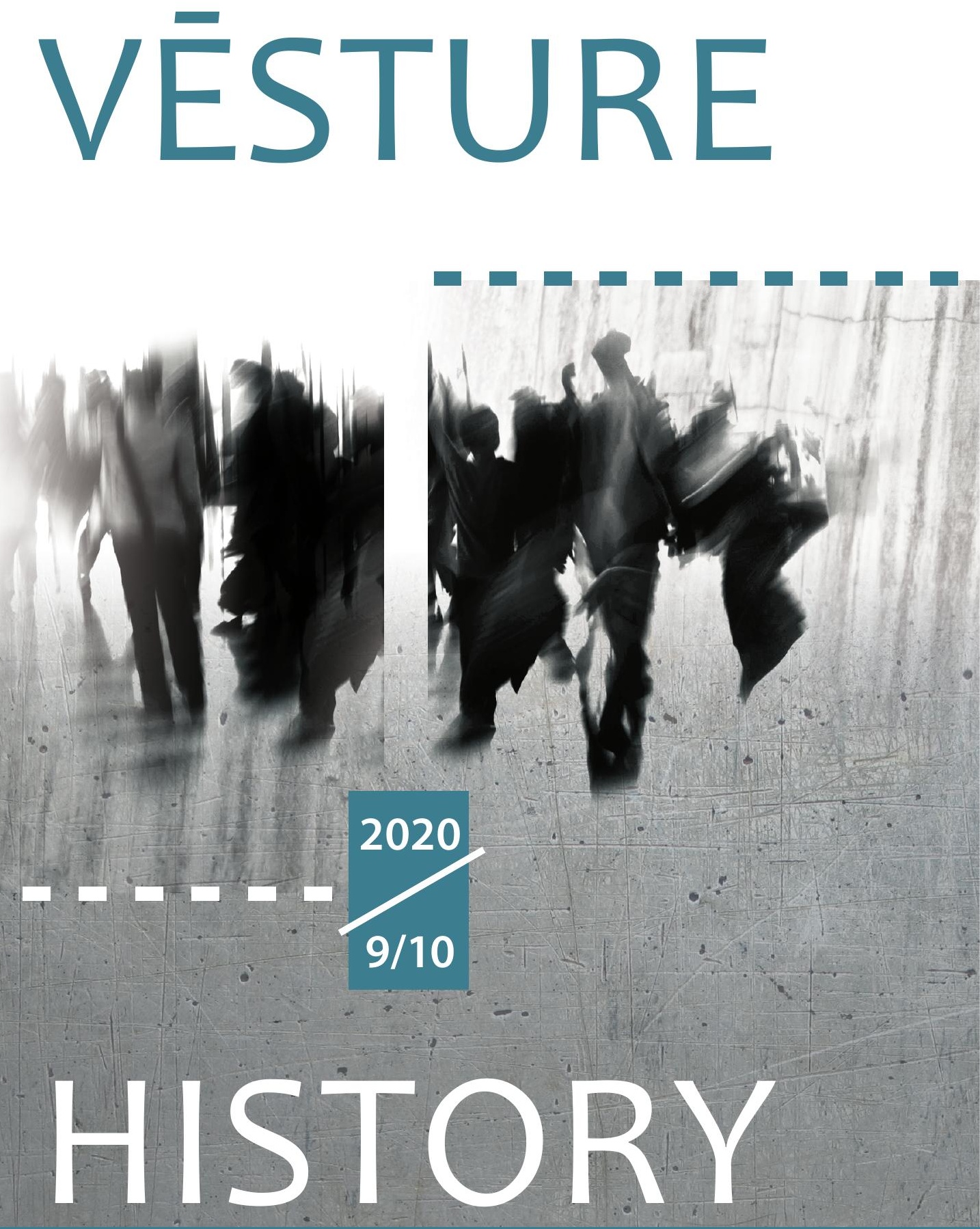

Journal of the University of Latvia 
Latvijas Universitātes Žurnāls

\section{VËSTURE}

Journal of the University of Latvia

HISTORY 



\section{Latvijas Universitātes Žurnāls}

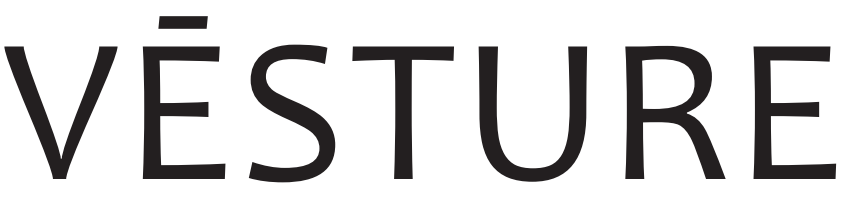

Journal of the University of Latvia

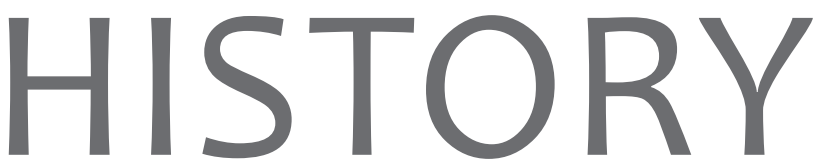


Dibinātājs

Latvijas Universitāte

Reğistrācijas numurs 90000076669

"Latvijas Universitātes Žurnāls. Vēsture" ir žurnāla "Latvijas Vēsture. Jaunie un Jaunākie Laiki" turpinājums. Šis laidiens ir minētā žurnāla 104./105. numurs.

Galvenais redaktors Jānis Taurēns - Dr. hist., LU Vēstures un filozofijas fakultātes asociētais profesors

Redakcijas kolēéija:

Ammons Českins - Ph. D., Glāzgovas Universitātes Sociālo un politisko zinātṇu skolas lektors Centrāleiropas un Austrumeiropas studijās

Inesis Feldmanis - Dr. habil. hist., LU Filozofijas un socioloğijas institūta vadošais pētnieks

Anderss Frejmarks - Ph. D., Linneja Universitātes Mākslu un humanitāro zinātṇu fakultātes asociētais profesors (Zviedrija)

Aleksandrs Ivanovs - Dr. hist., Daugavpils Universitātes Humanitārās fakultātes profesors

Ēriks Jēkabsons - Dr. hist., LU Vēstures un filozofijas fakultātes profesors

Valda Kḷava - Dr. hist., LU Vēstures un filozofijas fakultātes asociētā profesore, VFF dekāne

Samuels Kruizinga - Ph. D., Amsterdamas Universitātes docents mūsdienu vēsturē

Andris Levāns - Dr. hist., LU Vēstures un filozofijas fakultātes asociētais profesors

Mati Laurs - Ph. D., Tartu Universitātes Mākslu un humanitāro zinātṇu fakultātes profesors

Alans Marejs - Ph. D., Līdsas Universitātes Mākslu fakultātes vecākais pasniedzējs

Silviu Miloiu - Dr. habil. hist., Valahijas Universitātes profesors, Rumānijas Ziemeḷu un Baltijas studiju asociācijas prezidents

Torbens K. Nìlsens - Ph. D., Olborgas Universitātes Sociālo zinātņu fakultātes asociētais profesors Andrijs Rukkass - Dr. hist., Tarasa Ševčenko Kijevas Nacionālās universitātes Vēstures fakultātes asociētais profesors

Inese Runce - Dr. hist., LU Filozofijas un socioloǵijas institūta vadošā pētniece

Aivars Stranga - Dr. habil. hist., LU Vēstures un filozofijas fakultātes profesors

Andris Šnē - Dr. hist., LU Vēstures un filozofijas fakultātes asociētais profesors

Jānis Taurēns - Dr. hist., LU Vēstures un filozofijas fakultātes asociētais profesors

Jons Vaičenonis - Dr. hist., Vītauta Dižā Universitātes Humanitāro zinātṇu fakultātes profesors

Bredlijs Vudvorts - Ph. D. , Nūheivenas Universitātes Mākslu un zinātnu koledžas asociētais profesors Antonijs Zunda - Dr. habil. hist., LU Filozofijas un socioloğijas institūta vadošais pētnieks

No 2016. gada "Latvijas Universitātes Žurnāls. Vēsture" ir iekḷauts EBSCO datubāzēe "Central \& Eastern European Academic Source".

Literārā redaktore Gita Kḷaviña

Angḷ valodas teksta redaktore Andra Damberga

Maketētāja Andra Liepiña

Vāka dizainu veidojusi Baiba Lazdiṇa

Adrese

"Latvijas Universitātes Žurnāls. Vēsture"

LU Vēstures un filozofijas fakultāte

Telefons: + 37167034992

Aspazijas bulvāris 5, Rīga, Latvija, LV-1585

Visi žurnāla raksti ir recenzēti.

Pārpublicēšanas gadījumā nepieciešama Latvijas Universitātes aț̣auja.

Citējot atsauce uz izdevumu obligāta.

Par publicēšanai nepieņemtiem manuskriptiem redakcija paskaidrojumus nesniedz.

Par žurnālā ievietoto citātu atbilstību oriǵinālam atbild autori.

Žurnāla interneta vietne:

https://www.apgads.lu.lv/izdevumi/brivpieejas-izdevumi/

zurnali-un-periodiskie-izdevumi/vesture-history/

ISSN 2500-9621

(C) Latvijas Universitāte, 2020

https://doi.org/10.22364/luzv.9.10 
Established by

University of Latvia

Registration No. 90000076669

"Journal of the University of Latvia. History" is a continuation of the journal "History of Latvia.

Modern and Contemporary Period". The current journal is the $104^{\text {th }} / 105^{\text {th }}$ volume of the series.

General Editor Jānis Taurēns - Dr. hist., Associate Professor at the Faculty of History and Philosophy, University of Latvia

Editorial Board:

Ammon Cheskin - Ph. D., Lecturer in Central and East European Studies, School of Social and Political Sciences, University of Glasgow

Inesis Feldmanis - Dr. habil. hist, Leading Researcher, Institute of Philosophy and Sociology, University of Latvia

Anders Fröjmark - Ph. D., Associate Professor, Faculty of Arts and Humanities, Linnaeus University (Sweden)

Aleksandrs Ivanovs - Dr. hist., Professor, Faculty of Humanities, University of Daugavpils

Ẽriks Jēkabsons - Dr. hist., Professor, Faculty of History and Philosophy, University of Latvia

Valda Kl lava - Dr. hist., Associate Professor, Faculty of History and Philosophy, University of Latvia, Dean of the Faculty of History and Philosophy, University of Latvia

Samuël Kruizinga - Ph. D., Assistant Professor in Contemporary History, University of Amsterdam Mati Laur - Ph. D., Professor, Faculty of Arts and Humanities, University of Tartu

Andris Levāns - Dr. hist., Associate Professor, Faculty of History and Philosophy, University of Latvia Silviu Miloiu - Dr. habil. hist., Professor, University of Valachia, President, Romanian Association for Baltic and Nordic Studies

Alan Murray - Senior Lecturer, Faculty of Arts, University of Leeds

Torben K. Nielsen - Ph. D., Associate Professor, Faculty of Social Sciences, University of Aalborg

Andrij Rukkas - Dr. hist., Faculty of History, Taras Shevchenko National University of Kyiv

Inese Runce - Dr. hist., Leading Researcher, Institute of Philosophy and Sociology, University of Latvia

Aivars Stranga - Dr. habil. hist., Professor, Faculty of History and Philosophy, University of Latvia

Andris Šnē - Dr. hist., Associate Professor, Faculty of History and Philosophy, University of Latvia

Jānis Taurēns - Dr. hist., Associate Professor, Faculty of History and Philosophy, University of Latvia

Jonas Vaičenonis - Dr. hist., Professor, Faculty of Humanities, Vytautas Magnus University

Bradley Woodworth - Ph. D., Assisstant Professor, College of Arts and Sciences, University of New Haven

Antonijs Zunda - Dr. habil. hist., Leading Researcher, Institute of Philosophy and Sociology, University of Latvia

"Journal of the University of Latvia. History" since 2016 is included in EBSCO database Central \& Eastern European Academic Source.

Literary editor Gita Kḷavina

English language editor Andra Damberga

Layout Andra Liepina

Cover design Baiba Lazdina

Address

"Journal of the University of Latvia. History"

Faculty of History and Philosophy, University of Latvia

Tel.: + 37167034992

Aspazijas bulvāris 5, Riga, Latvia, LV-1585

All the papers published in the present volume have been subjected to the blind peer review.

No part of the volume may be reproduced in any form without the written permision of the publisher.

When quoting, the reference to the original publication is mandatory.

Editorial board does not provide commentary regarding articles rejected for publication.

Correspondence of the quotes published in the current journal to the original texts is the responsibility of authors.

Free access:

https://www.apgads.lu.lv/izdevumi/brivpieejas-izdevumi/

zurnali-un-periodiskie-izdevumi/vesture-history/

(C) University of Latvia, 2020

ISSN 2500-9621

https://doi.org/10.22364/luzv.9.10 


\section{Saturs / Contents}

\section{Redaktora sleja}

Editorial

\section{Raksti}

Articles

\section{Vija Stikāne}

Sievietes karos un militāros konfliktos Livonijā no 13. gadsimta

līdz 17. gadsimta sākumam

Women in Wars and Military Conflicts in Livonia from $13^{\text {th }}$ Century

Until Beginning of the $17^{\text {th }}$ Century

\section{Raimonds Cerūzis}

Kopīgās tendences Latvijas Universitātes un Latvijas Republikas vēsturē starp pasaules kariem

Common Trends Shared By the University of Latvia and the Republic

of Latvia Between the World Wars

\section{Dāvis Beitlers}

Iekḷaušanās. Dažas epizodes Latvijas jūrnieku profesionālajās

gaitās trimdā Rietumos. I dạ̣a

The Integration. A Few Episodes of the Professional Ways of Latvian

Seamen in the Western Exile. Part 1

\section{Yuri Slezkine}

The Good People: Loyalty and Betrayal in Moscow's

House of Government, 1937-1938

Labie laudis: lojalitāte un nodevība PSRS Valdïbas namā

1937.-1938. gadā

\section{Ilze Vaivode}

Tūrisma organizācija Latvijas PSR: Latvijas republikāniskās tūrisma padomes darbība 20. gadsimta 60. gados Organisation of Tourism in Latvian SSR: Activity of Republican Tourism Council of Latvia in 1960s 


\section{Eginhards Volāns}

Latvijas un Krievijas 1998. gada attiecību krīze:

cēloṇi un norise

Crisis in Latvian-Russian Relations in 1998:

Causes and Progress

\section{Vēstures avoti}

Historical Sources

\section{Ėriks Jēkabsons, Edmunds Trumpa}

Situācija Liepājā 1919. gada martā: Lietuvas tirdzniecības un rūpniecības ministra Jona Šimkus ziņojums

Situation in Liepāja in March 1919: Report by Minister of Commerce and Industry of Lithuania Jonas Šimkus

\section{Recenzijas}

Reviews

\section{Jānis Taurēns}

Latvijas diplomāti par mūsu ārpolitikas simtgadi

Recenzija par grāmatu: Mārtiņš Drēgeris (sast.). Latvijas diplomātijas gadsimts. Latvijas diplomātijas un ārlietu dienesta pirmais gadsimts (1919-2019)

diplomātu esejās. Rīga 2020. 606 lpp. ISBN 978-9934-0-8820-9

\section{Ziṇas par autoriem}





\section{Redaktora sleja / Editorial}

Ceḷu pie lasītājiem atradis kārtējais mūsu žurnāla numurs. Globālās pandēmijas apstākḷ̆os, kad arhīvi kādu laiku nav bijuši pieejami pētniekiem, esam sagatavojuši sešus akadēmiskus rakstus un vēstures avota publikāciju.

Žurnāla jaunajā numurā atspogulojas hronologijas un problēmu ziṇā plaša tematika, tas veltìts periodam no viduslaikiem Livonijas zemēs līdz 20. gadsimta beigām, tematikas ziṇā skarta gan sieviešu vēstures problemātika, gan cilvēku rīcība ekstrēmās situācijās, gan ikdienas dzìve un diplomātiskā vēsture.

Medieviste Vija Stikāne pievēršas sievietes lomai viduslaiku un agro jauno laiku konfliktos. Bieži vien tiek aizmirsts, ka sievietes un bērni karadarbības laikā cieš visvairāk. Autore pievērsusies dažādiem šìs problēmas aspektiem.

Vēsturnieks Raimonds Cerūzis aplūko kopīgās tendences Latvijas Universitātes (LU) un visas valsts liktenī periodā starp abiem pasaules kariem. Procesi, kas ietekmē valsti, atstāja iespaidu arī uz Universitātes likteni. Savukārt Universitāte kā valsts intelektuālās dzīves centrs nenoliedzami ietekmēja republikas likteni. Autors ir kritisks pret autoritārisma tendenču iespaidu LU dzīvē. Liela vieta rakstā atvēlēta personībām Universitātē. Daudziem no šiem cilvēkiem bija svarīga loma visas valsts vēsturē.

Vēsturnieka Dāvja Beitlera pētījumā skarta problēma par Latvijas jūrnieku integrāciju pēckara Rietumu tautsaimniecībā, pētot zinātniski aktuālo latviešu trimdas problēmu Rietumos. Latviešu jūrnieku apṇēmība strādāt un integrēties strauji augošajā ASV un Eiropas ekonomikā sadūrās ar dažādām problēmām un šḳēršliem, piemēram, darba tirgus aizsardzību Rietumu valstīs.

Vēsturniece Ilze Vaivode raksta par tūrisma organizāciju okupētajā Latvijā un par problēmām, ko tā radīja. Nav šaubu, ka jebkura personību attīstoša aktivitāte bija lietderīga un kliedēja padomju dzīves pelēcību, tomēr tūrisma organizācija cieta no visām padomju režīmam raksturīgajām problēmām, piemēram, vēlamā uzdošanas par esošo. Atsevišḳu padomju varas un pārvaldes struktūru izpēte ir svarīga, lai atklātu plašāku ainu par šì režīma darbības principiem, būvējot vēstures zinātnes māju no pamatiem.

ASV vēsturnieks no Kalifornijas Universitātes Bērkli Jurijs Sḷozkins žurnālam iesniedzis pārstrādātu nodalu no savas Prinstonā publicētās grāmatas par Valdības namu Maskavā. Tas bija vesels nomenklatūras dzīvokḷu komplekss ar neskaitāmām palīgtelpām un iespējām iemītniekiem. Staḷina represiju kulminācijas laikā nama iemītnieku privileǵētā 
dzīve sadūrās ar bezprecedenta krīzi: arestiem un nāvessodiem. Iekšlietu tautas komisariāta (NKVD) mašīnas jeb "melnie kraukḷi" kḷuva par biežiem viesiem namā. Autors norāda, ka apmēram 800 nama iemītnieku un nenoskaidrots skaits darbinieku tika izraidīti no saviem apartamentiem un apsūdzēti dažādos noziegumos. 344 iemītnieki, cik zināms, tika sodīti ar nāvi nošaujot, pārējiem piespriests dažāda veida un ilguma ieslodzījums. Tas bija pārbaudījums eksistenciālā līmeni, kas lika daudziem ieskatīties sevī un uzdot jautājumu - kāds cilvēks es esmu.

Vēsturnieks Eginhards Volāns raksta par vienu no nopietnākajām politiskajām krīzēm - gadsimta beigu Latvijas un Krievijas attiecību krīzi, kuras konteksts bija Latvijas eiroatlantiskās integrācijas process, kuru Krievijas vara nesekmīgi centās aizkavēt ar diplomātisku un politisku spiedienu, cenšoties izmantot Latvijas iekšpolitiskās problēmas.

Ēriks Jēkabsons un Edmunds Trumpa sagatavojuši izdošanai nepublicētu vēstures avotu - Lietuvas tirdzniecības un rūpniecības ministra Jona Šimkus ziņojumu par situāciju Liepājā 1919. gada martā. Ziņojumā minēti militārie un ekonomiskie aspekti tālaika Latvijā, kad savijās un sadūrās visdažādākās kaimiņvalstu un lielvalstu intereses, skarta arī Latvijas valdības sociālās un nacionālās bāzes problēma. Jons Šimkus bija pirmais Lietuvas valstsvīrs, kurš tikās ar Kārḷa Ulmaṇa vadīto valdību Liepājā.

Jānis Taurēns 
Raksti

Articles 



\title{
Sievietes karos un militāros konfliktos Livonijā no 13. gadsimta līdz 17. gadsimta sākumam
}

\section{Women in Wars and Military Conflicts in Livonia from $13^{\text {th }}$ Century Until Beginning of the $17^{\text {th }}$ Century}

\author{
Vija Stikāne, Dr. hist. \\ Īpaši aizsargājamā kultūras pieminekḷa Turaidas muzejrezervāts \\ direktora vietniece zinātniskā darbā \\ Turaidas iela 10, Siguldas novads, Sigulda, LV-2150 \\ E-pasts:vija.stikane@turaida-muzejs.Iv
}

Dažādu kārtu Livonijas sievietes karu un konfliktu laikā atradās aizsargājamā pozīcijā. Aktīva rīcība vai atriebība kara laikā piedēvēta zemākas kārtas sievietēm, kuras nelietoja ieročus. Livonijā karojošās puses uzskatīja sievietes par daḷu no kara laupijjuma, viņas varēja izmantot kā kīilnieces, darbaspēku vai kā konkubīnes, bet agro jauno laiku sākumā arī pieprasīt par gūsteknēm izpirkumu. Vienlaikus sieviešu nogalināšana un izvarošana kara apstākḷıs bija viena no apsūdzībām pretiniekam, lai to parādītu negatīvā gaismā, nereti ìpaši uzsverot vardarbību pret grūtniecēm.

Atslēgvārdi: sievietes, kari, gūsteknes, Livonija, viduslaiki, agrie jaunie laiki.

During the various wars of the medieval and early modern Livonia, women were subjected to guardianship because of their gender. Women did not fight; they did not use weapons nor defended themselves. Active action or revenge during the war was attributed to lower-ranking women. In wars, the children and women of enemies were captured as prisoners by local people - Baltic and Finnic peoples, by the crusaders, and by the Orthodox Christian Pskovians and Novgorodians, as well as the neighbouring Lithuanians, in the $17^{\text {th }}$ century - by Polish and Swedish warriors. It was allowed to ask for ransom until the early modern period. In medieval times, both Christians and pagans respected the lives of women and children in wartime. The lower-ranking women taken captive in wars became enslaved, serving as labourers or concubines. At the same time, killing or raping of women, or violence against pregnant women in wartime was one of the charges showing the enemy in bad light, which served as a part of propaganda to unite the forces to fight.

Keywords: women, wars, captives, Livonia, middle ages, early modern period. 


\section{levads}

Kara tēma ir saistīta ar daudziem un dažādiem aspektiem. Tas ir stāsts par kaujiniekiem un nekarojošiem civiliedzīvotājiem, par uzvarām un sakāvi brutālā cīniņā un diplomātiskā frontē, par nogalināšanu un pakḷaušanu, kara cēloṇiem un sekām, spēju mobilizēt sabiedrību, slēgt savienības, sadzīvot ar pakḷaušanās sekām. Lai kā attīstītos cilvēce un civilizācija, arī mūsdienās joprojām nav svešs priekšstats, ka karošana var būt likumīga, bet taisnīguma panākšana ar spēka metodēm ir viens no valstu, kopienu, tautu līdzāspastāvēšanas pamatprincipiem un ka arī kara upuriem, sieviešu un bērnu ciešanām var būt attaisnojums. Daḷā pasaules mūsdienās nepastāv nāves sods, un arī militāros konfliktos ir vēlme iztikt bez civiliedzīvotāju upuriem. Uz starptautiskām konvencijām balstīta izpratne par kara noziegumiem paredz civiliedzīvotāju aizsardzību un humānisma principu ievērošanu. Šīs starptautiskās sistēmas saknes tiešā un netiešā veidā tiek meklētas vispārcilvēciskās vērtībās, bet jo īpaši kristīgajā morālē, ietverot gan Rietumu, gan Austrumu kristietību. ${ }^{1}$ Kristīgajā Rietumeiropā gan ar kara tiesību, gan ar dievišķā miera (latīnu val. Pax Dei, vācu val. Gottesfrieden) iedzīvināšanu laicīgajā likumdošanā ${ }^{2}$ centās pasargāt karā neiesaistītos civiliedzīvotājus, arī sievietes, no karu negatīvajām sekām. Eiropas historiogrāfijā sieviešu iesaiste militāros konfliktos Rietumeiropā viduslaikos un agrajos jaunajos laikos ir pētìta visai daudz, tai skaitā par sievietēm un citiem "civilistiem" kā kara upuriem, taču Latvijas historiogrāfijā apkopojošu pētîjumu trūkst.

Šajā rakstā izvirzìts mērḳis apkopot rakstīto avotu ziņas no 13. gadsimta līdz 17. gadsimta sākumam par dažādu kārtu sieviešu lomu karadarbībā un konfliktos, par piedalīšanos aizsardzības organizēšanā un finansēšanā, kā arī aplūkot informāciju par sievietes aktīvu un pasīvu piedalīšanos militāros konfliktos. Jāatzīst, ka daudzo Livonijas karu analīze prasa pilnīgāku izpēti un daudz plašāku kontekstu nekā tikai Latvijas vai Livonijas (mūsdienu Latvijas un Igaunijas teritorija) viduslaiku un agro jauno laiku vēsture. Lai arī Livonijas sieviešu loma karos un konfliktos parādīta no dažādiem aspektiem un ziņas ir visai neviendabīgas, tomēr kopsaucējs ir - sieviete un karš.

\section{Sabiedrības virsslāṇa sievietes militāros konfliktos un matrimoniālos darijumos}

Provansiešu izcelsmes benediktiešu mūks Onorē Bonē (Honoré Bonet, ap 13401410) ap 1387. gadu atzīmēja, ka no kara tiesību viedokḷa sievietēm nevajadzētu piedalīties karā, pat ja viņas ir stipras, bagātas un māk apieties ar ieročiem. Ar to viņš zināmā mērā konstatēja situāciju Rietumeiropā - karadarbībā aktīvi mēdza iesaistīties dažas valdnieces. Viṇas patstāvīgi vai kopā ar kādu gimenes vīrieti vadīja savu vasaḷu karspēku, pašas cīnījās kaujas laukā ar ieročiem rokās. Tas atbilda vinu kārtas piederībai, audzināšanai, deva iespēju izpausties kareivīgam raksturam. ${ }^{3}$

Livonijā ilgus gadsimtus zemeskungu vidū nebija ǵimenes cilvēku - Vācu ordeña Livonijas mestrs, Rīgas bīskaps, arhibīskaps un citi bīskapi bija pakḷauti celibātam. Livonijas veidošanās laikā 13. gadsimtā vēl parādās informācija par vietējo maztautu valdnieci saistībā ar militārām norisēm. Hronists Indrikikis zina stāstīt, ka 1209. gadā, ieņemot Jersiku,

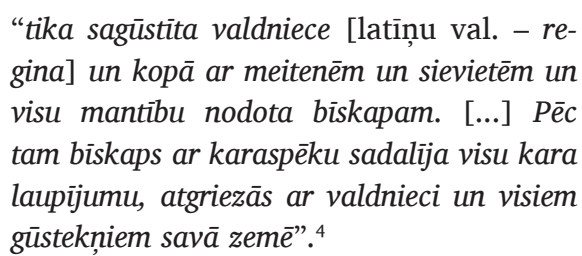


Hronikā latīṇu valodā lietotais vārds "regina", lai arī to nevar automātiski tulkot kā "karaliene" šā vārda izpratnē, kādu tobrīd lietoja Rietumeiropā, liecina par sievieti sabiedrības hierarhijas pašā virsotnē. Viṇas gūsts kḷuva par galveno iemeslu, kādēl miera noteikumus Jersikas Visval$\operatorname{dim}$ (Wyssewalde, Vissewalde, Wiscewolodus rex de Gercike) vēlāk diktēja Rīgas bīskaps. Viena no prasībām, lai atgūtu mieru un kīilnieci sievu, bija atteikšanās no savienības ar pagāniem. Šì prasība nozīmēja aizliegumu sadarboties ar sievas radiem - lietuviešiem. Jersikas Visvaldis, iespējams, bija piederīgs pareizticībai, savukārt viña sievas tēvs bija nekristītais lietuviešu augstmanis Daugerūts (Daugeruthe, Dangeruthe, ?-1214) 5 no Nalsenes zemes. ${ }^{6}$ Indrikia hronika apliecina Daugerūta piederību pagāniskajai ticībai, kā arī noturīgu militāru savienību ar lietuviešiem - dažkārt Jersikas Visvaldis vadīja apvienoto latgaḷu un lietuviešu karaspēku. ${ }^{7}$

Jersikas Visvalža sievas vārds, personības raksturojums un dzīves gaitas nav zināmas, taču var izdarīt dažus vispārīgus vērtējumus. Austrumeiropā un Baltijas jūras reǵionā 13. gadsimta sākumā precības apvienoja valdošo dinastiju gimenes, dibinot varas tīklojumu un dzimtu alianses, kas nostiprināja zemeskunga varu iepretī dzimtas aristokrātijas varai. ${ }^{8}$ Precības gandrīz vienmēr nozīmēja arī militāru sadarbību, kas stiprināja divu dzimtu spēku. Skandināvijā ap 11.-13. gadsimtu laulību rezultātā nodibinātie sakari pakāpeniski ieguva lielāku nozīmi nekā asinsradniecības saites, jo tie labāk kalpoja valdnieku politiskajām interesēm un l̦āva slēgt izdevīgas savienības. ${ }^{9}$ Jersikas valdnieka militārā savienība ar lietuviešiem, jādomā, balstījās galvenokārt uz precībās iegūtajiem sakariem, kas minēti Indriḳa hronikā, lai arī nevar izslēgt asinsradniecību. Spriežot pēc Indriķa hronikas, Jersikas Visvaldis pēc miera slēgšanas un vasaļattiecību dibināšanas ar Rīgas bīskapu turpināja sadarboties ar sievastēvu un lietuviešiem, sniedzot "padomu un palīdzību" (consilium et auxilium), kas noderēja par ieganstu atkārtotam krustnešu iebrukumam Jersikā (1214). ${ }^{10}$

Citas vietējo maztautu virsslāņa sievietes Indriķa hronikā nav ne minētas, ne sauktas vārdā. Domājams, vin̄ām nebija politiskas ietekmes, un tādu viṇām nepieškīira arī hronikas autors - piemēram, Pleskavas knaza Vladimira meita, kura tika izprecināta Rīgas bīskapa brālim Teodoriham no Bukshevdenas (Theodericus de Bekeshovede), nav saukta vārdā. Saradošanās noveda pie īslaicīgas savienības starp krustnešiem un kṇazu, kurš 1212./1213. gadā tika padzìts no Pleskavas. ${ }^{11}$ Jādomā, ka ar izraidīšanu pleskavieši protestēja pret militāro savienību, kas izveidojās precību rezultātā. Pleskavas kṇaza savienība ar krustnešiem nebija ilga, un sākotnējās draudzības saites starp Pleskavas kṇazu un vina znotu vairākās kaujas epizodēs bija no svara, taču pēc 1214. gada vini cīnījās kā naidnieki. ${ }^{12}$

Šis skopās ziņas par sievietēm sabiedrības hierarhijas virsotnē Baltijas jūras austrumkrastā papildina ziņas par valdnieci Ziemeḷigaunijā, kuras darbības raksturo, iespējams, maksimālās sieviešu iespēju robežas politiskajā un arī militārajā darbībā Baltijas jūras regionā 13. gadsimta otrajā pusē. Dāṇu karaḷa Kristofa atraitne Margarēte (1259-1282) līdz 1264. gadam nepilngadīgā dēla vārdā pildīja reǵentes funkcijas dāṇu karalistē, savukārt no 1262. līdz 1282. gadam tieši pārvaldīja dāṇiem piederošo Ziemeḷigauniju, lietojot personisko zìmogu un titulu "Margarēte, no Dieva dāṇu un slāvu karaliene, Igaunijas kundze" (Margareta, Dei Gratia Danorum Sclavorumque regina, domina Estoniae). ${ }^{13}$ Pēc vēsturnieka Paula Johansena (1901-1965) domām, Margarētes pavēle saistībā ar gatavošanos militārai sadursmei bija nozīmīgs solis Tallinas attīstībā: 1265. gada rudenī visiem pilsētas 
iedzīvotājiem - gan Olava draudzei piederīgajiem skandināvu pārceḷotājiem, gan vācu Nikolaja draudzei un augstdzimušajiem - bija kopā jānostiprina pilsētas apkārtmūris. ${ }^{14}$ Tas lika pamatus Tallinas aizsardzības spējām daudzu gadsimtu garumā. Margarētes iniciatīva pilsētas aizsardzības stiprināšanā sakṇojas vinas pieredzē valdošo g̛imeṇu cīṇās un tiešã militārā darbībā Jitlandes pussalā. Izmantojot Lundas arhibīskapa un pāvesta kūrijas atbalstu, Margarēte atraitnes statusā ne tikai iesaistījās diplomātiskos konfliktos un karos par savu un sava dēla varas saglabāšanu, bet pati vadīja karaspēku kaujā. ${ }^{15}$ Valdniece dāṇu zemēs jau 13. gadsimtā kḷuva leǵendāra, un hronikās viṇa dēvēta par "Melno Grietu" vai "Margarētu - zirgu", jo vinai piemitušas lielas spējas panākt iecerēto. ${ }^{16}$ Iespējams ka viņas kareivīguma skaidrojumā nav mazsvarīga viñas izcelsme Margarēte bija pomoriešu un obodrību knazu pēctece. ${ }^{17}$

Turpinot stāstu par dižciltīgām un bagātām sievietēm Livonijas teritorijā 14.16. gadsimtā, liekas log̣iski meklēt ziņas par Livonijas bīskapiju bruṇniecības dāmu aktivitātēm. Diemžēl publiskā sfērā šīs sabiedrības virsslān,a un karotāju kārtas sievietes darbojās maz. Viṇām, atškirībā no dažu Rietumeiropas zemju dižciltīgajām, ${ }^{18}$ nebija pilnīgas tiesiskas lēņspējas, lai varētu iesaistīties zemes pārvaldē un vadīt karaspēku. Saskaṇā ar Livonijas bruṇinieku tiesībām vienīgi atraitne - dēlu māte - varēja pildìt dienestu vai izvēlēties aizbildni, kurš to darīs viṇas vietā līdz dēlu pieaugšanai. ${ }^{19}$ Ziṇas par sievietēm, kas Livonijā personīgi pildītu lēṇu karadienestu senjora labā, autorei nav zināmas. Daži izlēņojumi apakšvasaliem liecina, ka pat atrast aizbildni ši pienākuma veikšanai krīzes situācijā varēja būt sarežgìiti. Tā Johana Rozena (Johann von Rosen) apakšvasaļa atraitne 1569. gadā sakarā ar nespēju pildīt lēna dienestu karalaukā atdeva lēni kungam. ${ }^{20}$
16. gadsimta otrajā pusē Livonijā atkal var runāt par zemes kundzēm - hercogienēm: Livonijas kara (1558-1582) rezultātā Livonijas garīgo zemeskungu pārvaldītās teritorijas tika sekularizētas un sadalītas starp kaimiņzemju monarhiem, veidojot vairāk vai mazāk no kaimiņzemju karaliem atkarīgas hercogistes. Livonijas sabrukuma laikā par zviedru, poḷu lietuviešu vai krievu princešu pūru noderēja Livonijas teritorijas, kuras bija jāaizstāv vai arī jāiekaro.

1561. gada decembrī Zviedrijas karalis Ēriks XIV (Erik XIV, 1533-1577) piedāvāja Rīgas arhibīskapa koadjutoram Mēklenburgas Kristofam (Christoph von Mecklenburg, 1537-1592) precēties ar savu māsu Elizabeti (1549-1597), kura pēc diviem vai trim gadiem sasniegtu precību vecumu. Līgavas pūrs bija Rīgas arhibīskapijas teritorija, bet precību nosacijums hercoga Kristofa vasal̨a zvērests Zviedrijas karalim, kurš tiktu dots pēc arhibīskapijas pakḷaušanas. Tika sastādīts un parakstīts laulību līgums. Zviedrijas karalis piedāvāja militāru palīdzību līgavas pūra atkarošanā, jo šajā laikā daḷa arhibīskapijas teritorijas jau bija Polijas-Lietuvas pārvaldē. Starpvalstu attiecības gan turpinājās neatkarīgi no iepriekšminētajām precībām, un iecerēto ne Zviedrijas karalis, ne Mēklenburgas Kristofs nepanāca. ${ }^{21}$

Viena no ievērojamākajām sievietēm 13.-16. gadsimta Livonijā bija pirmā Kurzemes un Zemgales hercogiene Mēklenburgas Anna (1533-1602) (minētā Kristofa māsa), kuras precības ar Gothardu Ketleru (Gotthard Kettler, 1517-1587) bija kara un politikas daḷa. Kāzas tika organizētas četrus gadus, un karadarbība iespaidoja gan precību, gan arī kāzu norisi. Jau sākotnējā vienošanās par precību organizēšanu starp Kurzemes un Prūsijas hercogiem 1563. gadā notika kara nometnē, bet pirms kāzām līgava un augstie viesi Kēnigsbergā ilgi gaidīja, jo līgavainis nevarēja ierasties karadarbības dēḷ. ${ }^{22}$ Pēc kāzām jaunā 
sieva pašrocīgi rakstīja vēstules slepenrakstā Prūsijas hercogam (1566), iespējams, ziņojot savam labvēlim par militāro notikumu gaitu Livonijā, t. i., spiegoja. ${ }^{23}$

Karadarbību Livonijā ietekmēja vairāku kaimiņzemju princešu precības un pūrs. Poḷu princeses Katrīnas Jagelones (Katarzyna Jagiellonka, 1526-1583) kāzas ar Somijas hercogu Johanu (Johan III Vasa, 1537-1592) 1562. gadā veicināja poḷu un zviedru attiecību saasināšanos. Polijas-Lietuvas karalis savam jaunajam svainim uz astoṇiem gadiem ieḳîlāja vairākas Livonijas pilis un novadus - Paidi, Helmi, Karksi, Tarvastu, Burtniekus, Trikātu, Ērógemi un Rūjienu. Tos Johans cerēja pievienot Somijai un izveidot no Zviedrijas neatkarīgu hercogisti, taču neveiksmīgi. Zviedrijas karalis Ēriks XIV 1563. gadā san,ēma Johanu un viņa sievu gūstā un okupēja minētos pilsnovadus, sākot zviedru un poḷu savstarpējo karu. ${ }^{24}$

Krievijas cara Ivana IV Bargā brālēna meitas Marijas Vladimirovnas Starickas (Maria Vladimirovna of Staritsa, 15601597/1612) precības ar pretendentu uz Livonijas mantojumu Sāremā-Lēnemā, Kurzemes un Tallinas bīskapu, Šlēsvigas-Holšteinas hercogu Magnusu (1540-1583) bija garants politiskai un militārai sadarbībai. ${ }^{25}$ Magnuss pieñēma Krievijas cara Ivana IV Bargā sūtṇu priekšlikumu 1570. gada vasarā, sadarbības un precību rezultātā iegūstot titulu "Livonijas karalis" (latīnu val. Divines Gratia Rex Livoniae Dominus Esthoniae at Littiae), ko viņš lietoja no 1570. līdz 1577. gadam. ${ }^{26}$ Tomēr Magnuss jau pēc četriem gadiem kopā ar sievu aizbēga uz bijušo Kurzemes bīskapiju, bet Maskavas cara Ivana IV Bargā vadītais karaspēks Livonijā 1577. gada karagājienā nežēlīgi atriebās pilsētniekiem un augstmaniem, kas bija zvērējuši Magnusam uzticību. ${ }^{27}$ Pēc vīra nāves 1583. gadā atraitni M. Staricku poḷu valdnieks Stefans Batorijs un kardināls Radivils zināmā mērā izmantoja kā ḳīlnieci diplomātiskās sarunās ar Krievzemes caru, un vina atgriezās Krievzemē. ${ }^{28}$

\section{Sieviešu loma karu finansēšanā}

Livonijā pirmā sievietēm uzliktā nodeva bija saistīta tieši ar karu. Vispārējo kontribūciju (gemeine Contributionn) un zirgu dienestu (Rossdienst) saskaṇā ar 1559. gada 25. jūlija landtāga lēmumu nācās maksāt visiem zemniekiem, tai skaitā sievietēm. Lai ordenis varētu bruņoties un nolīgt karakalpus, saimniekam bija jāmaksā viena mārka, saimniecei - pusmārka, kalpiem, kalponēm, bērniem no 12 gadu vecuma viens vērdiṇš (1/4 mārkas). ${ }^{29}$ Kā norādījis hronists Johans Renners (1525-1583), arī pilsētnieces maksāja šo ārkārtas kara nodevu. ${ }^{30}$ Individuālas kara nodevas sievietēm Livonijā bija jauna parādība, tāpat kā visā Baltijas jūras regionā, jo parasti sieviešu tiesiskā ierobežošana publiskajā sfērā, pastāvot dzimumaizbildniecībai, nozīmēja arī ierobežotus pienākumus, kurus vinuu vietā pildīja aizbildnis. Livonijas zemnieki īpašus kara nodokḷus (meistergeld, herrmeistergeld) maksāja ordeņa kasē no 15 . gadsimta sākuma, kad vien ordenis gatavojās "lielam karam", ${ }^{31}$ bet 16. gadsimta beigās un 17. gadsimta sākumā karavīru uzturēšanai tika vākta t. s. "zirgu nauda" un staciņš, kuru nomaksā sievietes bija iesaistītas netieši. ${ }^{32}$ Dižciltīgas sievietes kara kontribūcijas maksāšanā tika iesaistītas jau pēc Livonijas sabrukuma - individuāli aprēḳinātu kara nodevu ievāca lietuviešu-poḷu valdība 1590. gadā, attiecinot to ne tikai uz zemniekiem, bet arī uz muižniekiem, vinuu sievām un meitām. ${ }^{33}$

Efektīvu aizsardzību militāru konfliktu gadījumā veidoja lielākās Livonijas pilsētas. Sieviešu mantošanas tiesības un īpašumtiesības Livonijas pilsētās bija spēcīgas, un finansiāli neatkarīgām sievietēm bija jāpiedalās kopīgā pilsētu aizsardzības sistēmas 
nodrošināšanā. Rīgas un Tallinas aizsargmūru būvēšanā un uzturēšanā iesaistījās arī namīpašnieces (atraitnes), maksājot īpašus nodokḷus un izbūvējot drošas mūra dzīvojamās un noliktavu ēkas. ${ }^{34}$ Sievietes testamentos novēlēja naudu un līdzekḷus aizsardzībai - k̦ieǵeḷus aizsargmūra celtniecībai. ${ }^{35} 16$. gadsimtā Livonijas lielākajās pilsētās sieviešu bagātības, kas veidojās galvenokārt kā plašo mantošanas tiesību realizācija, bija ievērojamas, tomēr bagātas pilsētnieces, atškirīibā no vīriešiem, nemaksāja visas ar nekustamu īpašumu saistītās nodevas pilsētas kasē, tai skaitā militārām vajadzībām. Bagātā Tallinas tirgotāja Hansa Potgetera atraitne 1525 . gadā, pretstatā vienlīdz turīgiem vīriešiem, bija atbrīvota no visām tiešajām nodevām (Scho $\beta$, Wacke, Rutergeld, Sacharwerk) (klaušas pilsētas celtniecības darbos), un tas raisīja citu pilsētnieku neapmierinātību. Arī naudas ziedojumi pilsētas kasē un sešu vīriešu bruṇu komplektu dāvinājums pilsētai situāciju mainīja maz. ${ }^{36}$ Tātad līdz ar sieviešu mantošanas tiesību un īpašumtiesību nostiprināšanos viduslaikos un jauno laiku sākumā virziens individuālu nodokḷu virzienā bija logisks, tomēr visai lēns.

\section{Livonijas sieviešu aktīva iesaiste militārās aktivitātēs}

Baltijas jūras reǵionā ir dažas epizodes, kas krusta karu laikā rāda sievietes cīnāmies un aizstāvoties. ${ }^{37}$ Indriḳa hronikā pieminētas Rīgas vācu sievietes, kuras ar Dieva palīdzību aizstāvas pret kuršu uzbrukumu 1210. gadā, kā arī sāmsaliešu sagūstītās jerviešu sievietes - kristietes, kuras 1220. gadā kaujas laikā "izlēca laukā" un ar rungām sita jau sakautos pagānus sāmsaliešus, saukdamas: "Lai sit tevi kristiešu dievs!"38 Livonijas Atskaṇu hronikā minēts pamācošs gadijjums par Karkus novada krodzinieku igauni, kurš pierunāja savu sievu palīdzēt nosist kādu vācieti. Sieviete to arī izdarīja, lietojot cirvi, bet vēlāk vin,as jaundzimušajam bijušas tādas pašas rētas kā nobendētajam. ${ }^{39}$ Hermanis no Vartberges stāstā par 1343. gada igauṇu Jurğu nakts sacelšanos min satrakojušās sievietes (latīṇu val. - furiose mulieres), kuras nežēlīgi nogalināja vāciešus. ${ }^{40}$

J. Renners 16. gadsimtā, pamatojoties uz Bartolomeja Honekes jeb t. s. jaunāko atskanu hroniku, par Jurğu nakts sacelšanos 1343. gadā raksta, ka nevācu sievietes nosita vācu sievietes un bērnus. Savukārt, aprakstot Livonijas karu, minēta epizode par kādu nevācu meiteni no Ērǵ̀emes, kura, atriebdama mātes nāvi, 1560. gadā sekoja krievu karavīriem un sašautos nosita ar bomi. ${ }^{41}$ Rīgas patrimoniālajā apgabalā zemnieces 1578. gadā izrēkininājušās ar aplaupītājiem - nosita un pabāza tos zem ledus. ${ }^{42}$ Savukārt krievu sievietes pievienojās karaspēkam jau pašā Livonijas kara sākumā, piemēram, livoniešu aplenktajā Ringenā 1558. gada augustā aktīvi piedalījās aizsardzībā. ${ }^{43}$ 1581. gadā, zviedriem aplencot Hāpsalu, krievi dusmas izgāzuši uz zemniekiem, kuri bija devušies pie viņiem uz pili patverties. Kāda krievu sieviete ar savām rokām nožņaugusi septiṇus bērnus. ${ }^{44}$

Daži karu apraksti satur informāciju par sievietēm ziņotājām un spiedzēm. 1343. vai 1345 . gadā igauṇu nemiernieki, paslēpušies maisos ar labību, centās iekḷūt Vīlandes cietoksnī un to ieņemt. Kāda sazvērnieka māte, gribēdama nosargāt savu dēlu, viņus nodeva pils aizstāvjiem. Šì epizode, iespējams, balstās uz kādu vācu leǵendu, nevis patiesu notikumu. ${ }^{45}$ Domājams, ka pavisam reālas sievietes spiedzes bijušas Tallinā, kur pilsētas fogts 1458. gadā atzīmēja, ka Alhaida un Magdalēna par spiegošanu apcietinātas. ${ }^{46}$ Vācu ordeña uzticības persona 1502. gada februārī bija kāda sieviete, kura aizbēga no Pleskavas uz Tērbatu un livoniešus informēja par potenciālā krievu iebrukuma detal̦ām. ${ }^{47}$ Par Livonijas 
kara laiku vairākkārt atrodamas norādes, ka krievu karaspēks izmantoja sievietes kā spiedzes. 1560. gada februārī krievi sarunāja divas nevācietes izspiegot Ērǵemes pili, ${ }^{48}$ savukārt šĩ gada beigās krievu karaspēka nometnes vadītājs pie Paides nolīga kādu sievieti, lai uzzinātu, vai Rīga, Cēsis un Rauna var pretoties ienaidniekam. Vina spiegoja visai plašā apgabalā - Cēsīs, L̦audonā, Dzērbenē, Siguldā, Gulbenē, Rēzeknē, Rīgā. Sagādātās ziņas vēstīja, ka Cēsis un Rauna gatavojas aizstāvēties, bet Rēzeknes karakalpi dosies uz Cēsīm. Rīgā viṇa dzirdējusi, ka neviens nespēs pretoties un visi livonieši bēgšot. ${ }^{49}$ Arī vēlāk Poḷu-zviedru kara laikā (1601-1629) ir minēti gadījumi ar izspiegotājām, piemēram, aplenktajā Paides garnizonā kāda dižciltīga sieviete sūtījusi rakstiskus ziṇojumus, kurus pārtvēra, un pēc nopratināšanas viṇu sodīja ar nāvi, galvu uzspraužot uz mieta (pāḷa)..$^{50}$

No informācijas apkopojuma vērojams, ka sievietes militārā darbībā nepiedalījās, bet nevācu sievietes retos gadījumos vērsās pret pretinieku ar l,oti vienkāršiem palīgrīkiem, kurus pat nevar dēvēt par ieročiem. Jādomā, ka ieroču sievietēm nemaz nebija un viņas nebija apmācītas tos lietot. Dažas sievietes kara laikā izmantoja savas valodu zināšanas un iespēju brīvi pārvietoties, komunicējot ar dažādās valodās runājošiem karavīriem, pilsētu un piḷu iemītniekiem, lai vāktu kara vešanai noderīgu informāciju un tādējādi gūtu labumu. Piek̦eršanas gadījumā "vājais dzimums" tika sodīts ar lielu bardzību.

\section{Karagūsteknes un vardarbības upuri}

Nereti sievietēm karadarbība nesa gūsteknes vai kīlnieces likteni, nāvi, fiziskas ciešanas, seksuāla rakstura vardarbību. Pastāv pieṇēmums, ka Rietumeiropā viduslaikiem raksturīgie lokālie kari nebūt negāja rokrokā ar lielu vardarbību pret, mūsdienu valodā runājot, civiliedzīvotājiem, tajā skaitā ar sieviešu izvarošanu. ${ }^{51}$ Karu aprakstos tikai viduslaiku izskaṇā 15. gadsimtā parādās vairāk detaḷu, kas stāsta arī par karavīru vardarbību pret sievietēm kā laupī̌sanas kara sastāvdaḷu, piedēvējot vardarbību jeb īpašu nežēlību atškirīgām reliǵiskajām, etniskajām un sociālajām grupām..$^{52}$ Uzmanību saista pētījumi, kas apgalvo, ka viduslaiku beigās (15.-16. gs.) vācvalodīgajā Eiropas daḷā "spēles noteikumu maiṇa" dažkārt noveda pie nenormāla vardarbības potenciāla izlaušanās. ${ }^{53}$ Tomēr tiek uzdoti jautājumi par vardarbības uztveri un leg̣itīmo vardarbību kara laikā, jo, iespējams, tikai viduslaiku beigās tika izgaismoti karavīru ieradumi, kas reizēm pat nenonāca hronistu redzeslokā kā pārāk ierasti un ikdienišḳi, un mainījās ne tik daudz vardarbība, cik sankcionētas vai nesankcionētas vardarbības izpratne. ${ }^{54}$ Vēlajos viduslaikos tiek meklētas saknes Rietumu civilizācijas jēdzienam "kara noziegums", kas ieguva arī starptautisku kontekstu. ${ }^{55}$

Livonijā vairāku gadsimtu garumā militārie konflikti bija bieži un dažādi, un atškirīga varēja būt izpratne par taisnīgu karu, kas noteica iecietību vai tieši pretēji - pat rituālu vardarbību. Sirojumu karš, ticības jeb krusta karš ar teritorijas pakḷaušanu, lokāls atriebības karš - katrā bija iespējams savs modelis, kā tika veidotas attiecības ar pretinieka puses civiliedzīvotājiem.

Te nepieciešams noskaidrot, kāda bija sievietes dzīvības un goda vērtība saskanāā ar mums zināmajām liecībām par tiesību vēsturi. Livonijas tiesību normas atspogulojas 13.-16. gadsimta bruṇinieku, pilsētnieku un zemes (paražu) jeb zemnieku tiesībās. Visu sabiedrības kārtu tiesības balstījās uz dzimumaizbildniecību un par sievietes nogalināšanu, kā arī izvarošanu paredzēja augstāko soda mēru pakarot vai nocērtot galvu. ${ }^{56}$ Tātad ne tikai sievietes dzīvība, bet arī gods miera laikā tika vērtēts augstu. Livonijas zemes jeb zemnieku 
tiesībās, kas balstījās uz vietējām paražu tiesībām, atrodamas netiešas norādes uz palielinātiem sodiem par sieviešu sišanu un ievainošanu mājās, bet kaimiņzemēs pastāvēja dubults sods par sievietes apkaunojumu vārdos un darbos (sišana, zagšana un nogalināšana), īpaši mājās. Tas bija raksturīgi 14.-17. gadsimta baltu tautu parašu tiesībām. Palielināti sodu maksājumi par sievietes ievainošanu bija paredzēti Lietuvā, prūšu zemēs, kā arī kaimiṇu apgabalos - Mazovijā, Mazpolijā, tie piemēroti tiesu praksē arī Ziemeḷkrievijā - Novgorodas zemes Dvinskas rajonā (mūsdienās Arhangeḷskas apgabala dala) 13.-16. gadsimtā, bet tagadējās Baltkrievijas teritorijā (Grodṇas, Brestas zemes tiesās) līdz 17. gadsimtam. ${ }^{57}$ Mežainajā reǵionā ar visai skarbu klimatu apdzīvotības blīvums bija salīdzinoši neliels. Sabiedrību raksturoja augsta sieviešu mirstība fertilajā vecumā, ${ }^{58}$ un bija pamats vērtēt sievietes dzīvību augstu, kas, jādomā, visvairāk bija saistīts ar mātes lomu, taču arī sieviešu ieguldījums naturālajā saimniecībā bija liels, ipaši pārtikas, apgèrbu un citu resursu sagatavošanā, kas bija darbietilpīgs process.

Livonijas karu aprakstos raksturīga parādība ir karagūstekņi kā kara laupījuma daḷa. Karagūstekṇu statuss bija saistīts ar izcelšanos, un dzimtas, gimenes vai citu piederīgo pienākums un gods bija doties sievietes un bērnus glābt, izpirkt vai atriebt. Tā ǵimenes locekḷu un brālību biedru - vīriešu un sieviešu - izpirkšana no pagānu gūsta minēta Livonijas pilsētu gilžu statūtos. ${ }^{59}$ Pastāvēja nostādne, ka kristietis nedrīkst paverdzināt kristieti, arī karagūstekni, taču varēja prasīt izpirkumu.

Bagātās sievietes no ietekmīgām ğimenēm 13.-14. gadsimtā, nonākušas karagūstā, kḷuva galvenokārt par kīlniecēm, par kurām varēja iegūt nozīmīgu politisku labumu vai izpirkumu. ${ }^{60}$ Kiilnieces bija Jersikas Visvalža sieva ar pavadonēm, arī lietuviešu dižciltīgo gimenes locekles. ${ }^{61}$ Lietuvieši savstarpējos karagājienos 13. gadsimtā sagūstītās pretinieku sievietes izmantoja kā kīlnieces, pat ja viṇas bija radinieces. Tā Polockas ievēlētā knaza Daumanta sagūstītā Gerdeña sieva bija Daumanta tante Jevpraksija. ${ }^{62}$ Līdzīgi arī ordeṇbrāḷi 1377. gadā kā izcilu laupījumu vērtēja lietuviešu bajāra Kantalga sievu un gimeni un dižciltīgā Villegales sievu ar bērniem. ${ }^{63}$

Visai daudz ziņu par livoniešu gūstīšanu un izvešanu uz ienaidnieka zemēm ir 16. gadsimtā un 17. gadsimta sākumā. Livonijas kara laikā Livonijas vācieši lielā skaitā nonāca Maskavā, kur dižciltīgajiem bija iespēja sagaidīt izpirkumu, dzīvojot kopā ar ğimenēm. ${ }^{64}$ Livonijas hronikās arvien uzsvērts, ka gūstā tika vesti vācieši, īpaši vācu sievietes no pilsētām un pilīm. ${ }^{65}$ Daudzi Livonijas vācieši no pilsētām kḷuva par dienesta l̦audīm un zvērēja uzticību caram, palika Krievzemē arī pēc kara beigām, citiem bija iespēja atgriezties pēc Ivana Bargā nāves 1584. gadā. Maskavā gūstekņi no Narvas un Tērbatas patriciešu ǵimenēm atradās vēl 1599. gadā, un vairāki vīrieši bija dienesta l̦aužu vidū. ${ }^{66}$ Krievu karaspēks uz Maskavas kṇazisti aizveda Livonijas austrumdalas bagāto vasaḷu gimenes locekḷus un daudzus ilgstoši turēja gūstā, piemēram, Bērzaunes un Kalsnavas īpašnieka Heinriha Tìzenhauzena (Heinrich von Tiesenhausen, ap 1520-1600) gimeni. Savā testamentā (1591) H. Tīzenhauzens izklāstīja, ka viṇa sieva un pieci bērni tika sagūstīti krievu karagājiena laikā 1577. gada augustā, no tiem trīs bija meitas - Elizabete, Margareta un Barbara. Viṇa sieva gūstā pavadīja 10 gadus, līdz vīrs vinu un jaunāko meitu Margaretu izpirka no gūsta par ievērojamu summu. Divi bērni gūsta laikā mira, savukārt 1593. gadā bezvēsts pazudis jau 17 gadus skaitījās dēls, bet krievu gūstā joprojām tika turēta meita Barbara. ${ }^{67}$

Arī 17. gadsimta sākumā savu vērtību saglabāja bagātu gimeņu sievietes, par kurām varēja iegūt izpirkumu. Poḷu pusē 
dienošais Oto Dēnhofs 1604. gada 10. oktobrī kara nometnē pie Paides rakstīja zviedru karavadonim Ēriksonam lūgumu atbrīvot sava mirušā brāla Kristofera atraitni, kura šajā laikā turēta gūstā Zviedrijā. O. Dēnhofs cerēja vinu samainīt pret citu gūstekni vai pret izpirkumu. ${ }^{68}$

Zemāko un mazturīgāko slāņu karagūsteknes ticamākais liktenis bija saistīts ar kalpību. Tā varēja būt gan individuāla, ja vinuu pārdeva, gan kolektīva, ja sievieti pārvietoja kopā ar citiem karagūstekṇiem un nomitināja kādā vietā kā atkarīgo l,aužu grupas locekli. 13. gadsimtā Indriḳa un Atskaņu hronikā sastopama formula veiksmīgam sirojumam: vīriešus nonāvē, sievietes un bērnus aizved gūstā. Šādi siroja gan vietējo maztautu pārstāvji - baltu un somugru tautas, gan krusta karotāji, gan arī lietuvieši un pareizticīgie pleskavieši un novgorodieši. Vienlaikus par formulu varētu apzīmēt arī gūstekṇu pārvietošanu neatkarīgi no dzimuma: vienā barā ar lopiem vai sasietus dzina karagūstekṇus - vīriešus, sievietes, bērnus. ${ }^{69}$ Dažkārt ir attēlota arī sagūstìto gūstekṇu, nereti tieši sieviešu, atbrīvošana. ${ }^{70}$

Indriķis savā hronikā par gandrīz nepārtrauktajām militārajām sadursmēm 13. gadsimta sākumā sirojumus min bieži, un tikpat bieži sastopama formula par kara laupijjumu, kas veiksmes gadījumā bija arī no ienaidnieka zemes pārvestās gūsteknes, jo meitenes "karaspēks šajās zemēs mēdz vienīgās saudzēet". ${ }^{71}$ Sieviešu gūstīšana hronikā minēta desmitiem reižu. Tikai dažreiz Indriḳis min sieviešu nogalināšanu, to saistot ar konkrētiem apstākḷiem - jaunkristìtie Beverīnas un Tālavas latgaḷi jeb leti, tikko pieṇēmuši katoḷu ritu, nogalināja arī pagānu sievietes. Varētu šķist, ka viņi atmet veco laiku paradumus un ar pilnu degsmi vēršas pret pagāniem, bet Indrikisis to skaidro citādi: "leti [...] ir nežēlìgāki par citām tautām un neprot kā evangéēlija kalps žēlot otru kalpu".72 Cits gadījums minēts saistībā ar Tērbatas aplenkšanu, pirms kuras krustnešu vadonis un fogts, dižciltīgs un bagāts vīrs Frēdelhelms aicināja uz pretinieka iebaidīšanu: "visās pilīs, ko livvemnieki lìdz šim iekarojuši, ienaidnieki taču vienmēr paturējuši savu dzìvību un brīvìbu", un pēc iebrukuma "tūdal sāka apkaut tautu, kā vìriešus, tā arī dažas sievietes, un nesaudzēja viñus... [...] Pēc tam viñi pañēma krievu ieročus, drēbes, zirgus un visu kara laupijumu, kas bija pilī, kā arī pāri palikušās sievietes un bērnus". ${ }^{73}$ Atskaņu hronikā pretinieka sieviešu nogalināšana minēta vairākkārt, attiecinot to kā uz pagāniem igauṇiem un lietuviešiem, tā arī uz krustnešiem un ordeña bruniniekiem. ${ }^{74} \mathrm{Ja}$ sievietes bija patvērušās kādā cietoksnī un cietoksnis tika ienemts triecienā, tad vin̄ām žēlsirdība nepienācās. Vecākajā Atskaṇu hronikā precizēts, kāda vecuma bērni un kādas sievietes tika saudzētas: Dzintares pilī ordeņbrāḷi pēc aplenkuma 1261. gadā saudzēja tikai dažas kuršu sievietes, kuras pašas lūdza par savu dzīvību. Netika nogalināti bērni, jaunāki par 11 gadiem. ${ }^{75}$ Krustnešu attieksme sakṇojās krusta karu ideologijā, ${ }^{76}$ un pie Ziemeḷu krusta karu būtības piederēja kristiešu vardarbība pret pretiniekiem kopumā, ietverot arī vardarbību pret kristiešiem. ${ }^{77}$ Paralēles saistībā ar sieviešu dzīvības nesaudzēšanu īpašos apstākḷos var saskatīt Brēmenes zemeskungu krusta karā pret Štēdingas zemnieku republiku Lejassaksijā. Nemiernieki tika deklarēti par ķeceriem, pāvests akceptēja krusta karu. 1234. gadā krustneši Brēmenes arhibīskapa vadībā saskaṇā ar Erfurtes annālēm nogalināja visus pilsētas aizstāvjus, ieskaitot sievietes un bērnus. ${ }^{78}$

13. gadsimta Livonijas hronikās uzsvērta gūstekṇu ieguves vieta: sievietes, bērni, lopi nereti tika sagrābti mājās jeb ciemos. Dažkārt viṇi paspēja patverties koka pilīs. Te var vērst uzmanību uz juridisko saturu, ko Livonijas paražu tiesībās ietvēra termins "mājās". Sievietes dzīvība saskaṇā ar 
paražu tiesību principiem bija īpaši aizsargājama. Livonijas zemes tiesībās nepastāvēja juridiskas normas, kas īpašu aizsardzību nodrošinātu sievietēm, taču vairākas normas attiecās tieši uz lauku ḷaužu ievainošanu mājās. ${ }^{79}$

Tātad formula veiksmīgam sirojumam - vīriešus nonāvē, sievietes un bērnus aizved gūstā - varētu tikt skatīta zināmā mērā pozitīvā gaismā: karotāji saudzēja sievietes dzīvību. Motīvi tam, iespējams, nebija loti cēli, jo sievietes un bērni nereti tika uzskaitīti vienā rindā ar citu kara laupījumu: zirgiem, mājlopiem, apgēērbu. Kara laupijjuma aprakstos 13. gadsimta beigu un 14. gadsimta Livonijas hronikās pārvietotie gūstekṇi bija kā sievietes, tā vīrieši, un dzīvības saudzēšana bija saistīta ar vēlmi gūstekņus izmantot kā atkarīgu darbaspēku. Verdzības (drellības), bet no 15. gadsimta beigām dzimtbūšanas pastāvēšana veicināja gūstekṇu tvarstǐšanu sirojumu laikā.

Pastāv viedoklis, ka liela skaita karagūstekṇu pārvietošana bija raksturīga antīkajai pasaulei, bet līdz ar kristietības izplatību šì paraža Rietumeiropā izzuda. ${ }^{80}$ Agrajos viduslaikos Eiropā kara laupijums ietvēra civiliedzīvotājus, un gūsteknes tika vērtētas augstāk par gūstekņiem vīriešiem. ${ }^{81}$ No pretinieka zemes pārvestās gūsteknes, tāpat kā agro viduslaiku germāṇu un 11.-12. gadsimta rietumslāvu un skandināvu sabiedrībā, tika pārdotas, dāvinātas, ņemtas par konkubīnēm, retāk par sievām, kā arī par kalponēm jeb mājas verdzenēm atkarībā no sievietes izcelsmes. ${ }^{82}$ Livonijā un kaimiṇvalstīs sirojumu jeb laupīšanas kari, kā arī karagūstekṇu pārvietošana bija raksturīga ilgstoši. Gan pagāni, gan Romas un griek̦u katoḷi vienlaikus respektēja sieviešu un bērnu dzīvību kara laikā, bet uzskatīja tos par labu kara laupījumu. ${ }^{83}$ Sieviešu gūstīšana un atkalatbrīvošana Austrumeiropas daḷas mežu joslā tiek skaidrota kā būtisks sirojumu karu struktūrelements gadsimtiem ilgi jau pirms Livonijas izveidošanās. ${ }^{84}$ Kristīgo hronistu acīs šāds karošanas veids tika vērtēts dažādi, gan uzsverot saudzējošu attieksmi pret dzīvību, gan kā atriebības karš, kura laikā nogalināti visi pretinieku puses vīrieši, un te var saskatīt saistību ar Vecās Derības sižetiem par atriebību. ${ }^{85}$ Sirojošajām pusēm sieviešu un bērnu dzīvības saudzēšanas princips bija labi zināms, un tas varēja būt viens no elementiem, kas ierobežoja vardarbību un novērsa pārāk liela cilvēku skaita nogalināšanu. ${ }^{86}$

Karagūstekṇu deportēšana bija raksturīga Vācu ordenim. 13. gadsimta beigās Kursā un Zemgalē ordeṇa brāli kā kara laupījumu "sveikus un veselus" vai "labi sargātus" veda vīrus, sievas, meitas, bērnus un zirgus, kā arī vēršus no Grobiṇas, Mežotnes un Dobeles uz Kuldīgu, no Sidrabes uz Jelgavu, zemgaḷus uz Rīgu. ${ }^{87}$ Abu dzimumu gūstekṇu pārvietošana piederēja pie Vācu ordeņa kara taktikas arī Prūsijā un Žemaitijā, kā rezultātā līdz 15. gadsimta sākumam tika iznīcināti vairāki senie varas centri, lieli novadi palika gandrīz tukši. Vēsturnieks Svens Ekdāls (Sven Ekdahl) uzskata, ka ordenis karošanas veidu, kuram raksturīgs liels skaits pārvietotu karagūstekṇu, pārṇēma no vietējām Austrumbaltijas tautām kā šeit jau pirms 13. gadsimta plaši lietotu praksi, to vēl attīstot. Ordenis izmantoja gūsteknus kā darbaspēku, veicinot ordeña saimniecisko uzplaukumu, īpaši 14. gadsimtā. ${ }^{88}$ Gūstekṇi tika vesti uz Livoniju gan no Lietuvas, gan no tuvējām pareizticīgo zemēm. Viens no ordeṇa iedzivotāju pārvietošanas mērḳiem cita starpā varēja būt pierobežas zonas attīrišana no iedzīvotājiem, lai to būtu ērtāk aizstāvēt, cits iemesls - iedzīvotāju bojāeja sērgu un karu dēḷ un nepieciešamība pēc darbarokām. Ordenis pārdeva gūstekṇus un gūsteknes līdz 15. gadsimta pirmajai pusei un savās muižās izmantoja viṇu darbu. ${ }^{89} \mathrm{Uz}$ pārdotajiem gūstekņiem attiecināms vārds "drellis". Viduslejasvācu valodā minēts īpašs nosaukums: līdzās dreḷliem bija arī drevel, drellyne - aizvestās karagūsteknes. ${ }^{90}$ 
Livonijā ne tikai ordenis, bet arī citi zemeskungi, pilsētas un vasaḷi zināmā mērā profitēja no gūstekṇiem. ${ }^{91}$ Pilsētās karagūsteknes nokḷuva ne tikai tieši no kara lauka, bet arī ar tirgotāju starpniecību. Vitebskas kṇazam 1300. gadā tika iesniegta Rīgas rātes sūdzība, kuru atveda Rīgas pilsoṇi: netālu no Vitebskas Rīgas pilsonim, kurš brauca pirkt gūsteknes, uzbruka un vinu aplaupīja. ${ }^{92}$ Jādomā, ka tirgotāja mērkis bija svešzemju (nekristītās?) gūsteknes ne tikai pirkt, bet arī pārdot, tai skaitā Livonijā. Savukārt Tallinas pilsoṇa Ludekes Vildes mājās 1375. gadā bija pirkta sieviete, kura kalpoja šim tirgotājam un viņa sievai. Narvas fogts rakstijja Tallinas rātei: pārdotās sievietes vīrs bija kḷuvis par kristieti un tagad esot loti noderīgs. Līdz ar to Narva pieprasīja Tallinas pilsonim jeb viņa prombūtnes gadījumā viņa laulātajai draudzenei atdot jaunkristītajam vīram sievu, par ko solījās dot naudu vai vietā divas citas nebrīvas sievietes. ${ }^{93}$

Dažkārt rakstos īsi minēts, ka kara laupījumu, arī sievietes un bērnus, sadalīja pa kvotām, un karagājiena dalībnieki saṇēma savu daḷ. Tā 1375. gadā Livonijas mestrs atgriezās no Lietuvas un sadalīja 15 abu dzimumu karagūstekṇus. ${ }^{94}$ Karagūsteknes nonāca arī vietējo tautu karotāju saimniecībās. Tautasdziesmās minētās leišu meitas velētājas, malējiṇas, maizes cepējas, kā raksta Arveds Švābe (1888-1859), varētu būt tautas atminas par sirojuma kariem un t. s. ordeña laikiem. ${ }^{95}$ Jāatceras, ka darbi mājsaimniecībā bija laikietilpīgi un fiziski smagi, un graudu malšana rokas dzirnavās varēja būt pat simbols verdziski grūtam sieviešu darbam, kas akcentēts aprakstos par Svētās zemes krusta kariem. ${ }^{96}$ Arī rīdzinieki bija pazīstami ar šo simbolu, kad apgalvoja, ka 1298. gadā vācu ordeņbrāḷi sagūstìto pretinieku sievas gluži kā verdzenes piespieda malt ar rokām. ${ }^{97}$ Vienlaikus t. s. mājas vergu statuss Livonijā varēja būt līdzīgs kā Novgorodā vai lietuviešu augstmaṇu ǵimenēs, un verdzība visumā nebija Livonijas ekonomikas stūrakmens. ${ }^{98}$

Livonijā drellības ierobežošana notika 15. gadsimta sākumā, vēlāk nekā Skandināvijā, ${ }^{99}$ savukārt kaimiņzemē Lietuvas lielkunigaitijā karagūstekṇu liktenis tika atvieglots 15. gadsimta vidū. Tika noteikts, ka pirkts karagūsteknis varēja kḷūt brīvs bez saimnieka piekrišanas, ja bija kristietis, ko pārdeva ebreji vai tatāri. Bērni, kas piedzimuši "pirktai sievietei", strādāja sava kunga labā septinus gadus un tad kḷuva brīvi. ${ }^{100}$ Maskavas kṇazistē savukārt 15. gadsimtā tika tiesiski pamatots, ka ir valsts un privātie gūstekṇi, un privātos gūstekņus drīkstēja pārdot vai izmantot kā mājas vergus. 16. gadsimtā pastāvēja likumdošanas akti, kas atgādināja, ka kristiešus nav vēlams pārdot par vergiem, taču pareizticīgo zemēm iekarojumu rezultātā 16. gadsimtā tika pievienotas teritorijas, kur pastāvēja verdzība. Maskavas lielkņaza dienesta ļaudīm musulmaņiem 16. gadsimta otrajā pusē pienācās daḷa no karagūstekņiem kā atalgojums, ${ }^{101}$ savukārt Livonijas karagājienā 1577. gadā cara karaspēkā bija ne tikai tatāri, bet arī vergu tirgotāji no Osmaņu impērijas. ${ }^{102}$

Vienlaikus ar karagūstekņu vešanu uz Livoniju notika arī cilvēku izvešana uz kaimiņu zemēm. Cilvēku gūstǐšana kā raksturīga iezīme visai ilgi piedēvēta livoniešu kaimiņiem lietuviešiem gan kā pagāniem, gan arī jau kristiešu statusā un nereti arī gadījumos, kad lietuvieši bija kādas Livonijas partijas militārie sabiedrotie. Aizvesto cilvēku skaits un apraksts ir dažāds - nereti minot tikai vispārīgi, ${ }^{103}$ citreiz nosaucot konkrētus skaitḷus, piemēram, 1334. gadā ap 2000-2600 cilvēku. ${ }^{104}$ Gūstekṇu pārvietošana saskaņā ar Vācu ordeṇa herolda Magdeburgas Vīganta hroniku lietuviešiem bijusi raksturīga arī Lietuvas un Prūsijas pierobežā, turklāt Kuršu kāpās vietējie iedzīvotāji - vīri, sievas un bērni - pēc padošanās esot pat bijuši spiesti pien,emt 
lietuviešu reliǵiju. ${ }^{105}$ Pleskavas hronikā lietuviešu karavīri arī kā algotṇi raksturoti kā potenciāli bīstami sievu un meitu aizvedēji (1340). ${ }^{106}$

Sieviešu ņemšanu gūstā jeb iedzīvotāju pārvietošanu ar vai bez ǵimenēm praktizēja arī livoniešu austrumu kaimiṇi - pareizticīgie novgorodieši un pleskavieši. Novgorodas hronika, runājot par kariem, lieto raksturīgo formulu par sieviešu un bērnu gūstīšanu un pārvešanu no karagājiena. 1066. gadā Novgoroda tika ienemta "ar visām sievietēm un bērniem”; 1130. gadā kṇazs Vsevolods ar novgorodiešiem devās uz somugru zemi (Chjud' zimß) un no karagājiena pārveda sievietes un bērnus; 1200. gadā karaspēks no Lukiem Latgalē mājās atrada 40 vīrus, tos nogalināja, bet sievietes un bērnus aizveda; 1210. gadā kṇazs karagājienā uz Rjazaṇu paṇēma sievietes un bērnus, bet pilsētu nodedzināja. ${ }^{107}$ Arī daudzus gadsimtus vēlāk pleskaviešu hronists ar lepnumu rakstīja par 1480./1481. gada ziemas karagājienu uz Livoniju: "atveda gūstā lielu daudzumu vīriešu, sieviešu, jaunavu un mazu bērnu, zirgu un lopu". ${ }^{108}$ Kādā aprakstā par pleskaviešu un to sabiedroto maskaviešu sirojumu 1501. gada novembrī pat minēts, ka sirotājiem bijuši 1600 suṇu, kas dzina pēdas mežos sabēgušajiem zemniekiem. ${ }^{109}$ Savukārt hronists Rusovs par šo iebrukumu rakstija:

“[...] ar sievām, jaunavām un maziem bērniem krievi apgājās tā, kā tas nav dzirdēts pat par turkiem. Krievi bija šini laikā ap 40000 cilvēku noslepkavojuši un aizveduši gūstā." 110

Lai arī šajā gadījumā aizvesto iedzīvotāju skaits var būt pārspīlēts, ${ }^{111}$ tas sasaucas ar vēlākajām visai plašajām gūstekṇu izvešanām uz austrumiem 16. gadsimtā. Vai karagūsteknes palika kaut kur Pleskavas apvidū, vai tika pārdotas tālāk, nav zināms, bet fakts par lokālu dzīvesvietu minēts ordeṇa dokumentācijā - 1495. gadā no tuvējām zemēm Livonijā ieradās divas pārbēdzēju ǵimenes, kuras atveda uz pleskaviešu zemi gūstā aizvestas nevācu sievietes un izteica vēlmi tās bez atlīdzības atdot viṇu ğimenēm. ${ }^{112}$

Livonijas kara laikā Maskavas cara karaspēks no Livonijas un arī Lietuvas izveda daudz gūstekṇu. ${ }^{113}$ Krievu vēsturnieki runā par vairākām mērḳtiecīgi realizētām Livonijas vāciešu deportācijām 1558.1560., 1564.-1565., 1577.-1578. gadā. ${ }^{114}$ Daḷa gūstekṇu kḷuva par tatāru kara laupījuma daḷu un nonāca vergu tirgū musulmaṇu zemēs. Sievietēm un vīriešiem no Livonijas bija sava pārdošanas cena. ${ }^{115}$ Sākotnējo Maskavas lielkṇaza uzbrukumu mērḳis 1558.-1561. gadā bija nevis teritorijas iekarošana, bet gan zemes izsirošana, postošs uzbrukums, pēc kura piedāvāt sarunas, ${ }^{116}$ un sagūstītos veda uz Pleskavu, Novgorodu, Vladimiru, Kostromu un citām vietām. ${ }^{117} 16$. gadsimta 70 . gados livonieši uz tatāru zemēm tika pārvesti caur Maskavu. ${ }^{118}$ Šajā laikā Livonijas hronikas īpaši uzsver vardarbību pret sievietēm karadarbības laikā, tā izpaudās gan kā nogalināšana un seksuāli uzbrukumi, gan aizvešana gūstā. Livonijas mestra sekretārs Zolomons Hennings (Salomon Henning, 1528-1589) aprakstīja uzbrukumu Tērbatai un Narvai 1558. gadā, norādot, ka daḷu sagūstìto sieviešu kā lopus aizveda izpriecām, daḷu pārdošanai uz tatāru zemēm. ${ }^{119}$ Rusovs uzskaita vai visu Livonijas sabiedrību - karotājus, zemniekus, sievietes, jaunavas, bērnus, kalpus, kalpones, kurus aizveda gūstā, un sievietes bija spiestas pret pašu gribu dzīvot ar maskaviešiem un tatāriem kopdzīvi. ${ }^{120}$ Līdzīgi un vēl skarbāki novērojumi un secinājumi atrodami dāņu diplomāta Jēkaba Ulfelda (Jacob Ulfeldt, 1535-1593) aprakstā. Viṇš pie Tveras satikās ar tatāriem, kuri 1578. gadā atgriezās no Livonijas karagājiena ar daudziem gūstekṇiem. ${ }^{121}$ Gūstekṇi bija daḷa no kara laupījuma, kas 
pienācās Maskavas cara karaspēka dalībniekiem, un tika izmantoti kā atkarīgi kalpi, mājas kalpi un kalpones. Piemēram, Livonijas kara gūstekne, jauna sieviete, tika dota līdzi pūrā augstdzimušai krievu līgavai. ${ }^{122}$ Tāpat gūstekṇi tika arī nometināti kā atkarīgie zemnieki tatāru zemēs. ${ }^{123}$

Vienlaikus Livonijas kara laikā rakstos ir sastopamas dažas sūdzības par livoniešu sabiedrotajiem lietuviešiem, kuri gūstījuši zemnieces. Prūsijas hercoga sūtṇi un pilnvarnieki Livonijā 1563. gadā rakstīja hercogam, ka no Polijas-Lietuvas karaḷa l̦audīm draudot tādas pašas briesmas kā no ārzemju jeb krievu ienaidniekiem. Viṇi k,erot un aplaupot nabaga laudis un vinu sievas un bērnus sūtot strādāt uz saviem īpašumiem Lietuvā. ${ }^{124}$ Līdzīgi arī Tallinas rāte 1567. gadā rakstīja Minskas kastelānam, polı augstmanim un Daugavpils hauptmanim, ka poḷu (un lietuviešu) karaspēks laupa un dedzina, kā arī no zemniekiem aizved bērnus, īpaši meitenes. ${ }^{125}$

Galu galā var minēt arī zviedru ìstenoto deportāciju Livonijas teritoriālajās robežās Poḷu-zviedru kara laikā: 1612. gadā zviedru karspēks, ielauzies dān,iem piederošajā Sāremā, centās vai visus zemniekus aizvest gūstā, lai tos nometinātu viņiem piederošajā Lēnemā jeb Vīkas novadā. ${ }^{126}$

\section{Vardarbība un atriebība}

Raksturojot sieviešu situāciju kara apstākḷos, uzmanību saista vardarbības izpausmes pret "vājo dzimumu", kas laikabiedros izraisīja īpašu sašutumu un šausmas. Livonijas vēstures avotos netrūkst norāžu par demonstratīvi nežēlīgu mocīšanu, sieviešu izvarošanu, grūtnieču un jaundzimušo uzšķēršanu. Tie ir stāsti, kas raksturīgi ne tikai Livonijai, bet ir sastopami teritoriāli un hronolog̣iski plašā tvērumā Rietumu latīṇu kristiešu rakstītajās hronikās. To mērḳis bija gan veidot pamācošu vai sensacionālu stāstu, gan dramatizēt situāciju, lai pamatotu taisnīgu karu (nereti - tā kā hronikas ir garīdznieku rakstītas - pret kristiešu ienaidniekiem). Aprakstot igaunu 1343. gada sacelšanos, Bartolomeja Honekes hronikā un vēlāk Rennera Livonijas vēsturē uzsvērts, ka igauṇi nogalināja vai gribēja nogalināt visus vāciešus līdz mazgadīgajiem, visas vācu sievietes, bērnus, mūḳenes, vācu jaunavas, sievas, kalpus, kalpones, dižciltīgos un vienkāršos, jaunus un vecus vāciešus, sita pie krusta kādu zēnu. ${ }^{127}$ Vartberges Hermanis raksta:

"Viṇi [vāciešu] bērnus trieca pret akmeñiem vai iemeta ūdenī un - ko jākaunas teikt - sievietes uzškērda ar zobeniem, un no vinu miesām izkritušos bērnus pārdūra ar škêpiem." 128

Vartberge savā darbā bija pilnīgs ordeņa apologèts, diezgan brīvi manipulējot ar faktiem par Livonijas vēsturi, ${ }^{129}$ un no viņa teiktā ir skaidrs, ka Vācu ordenim vajadzēja iejaukties un glābt kristiešus - ne tikai no igauniem, bet arī no vinu kungiem dān,iem. Vienlaikus jāatzīmē, ka gan Honekes, gan Vartberges aprakstītās mežonības epizodes rod l,oti konkrētas paralēles detal̦u aprakstos Rietumeiropas 12. gadsimta historiogrāfijā, kā arī stāstos par svēto karu Palestīnā, Simtgadu karu, Žakēriju, angḷu un skotu cīnām. ${ }^{130}$ Šajā aspektā Livonijas hronikas daḷeji turpina Eiropas viduslaiku hroniku tradīciju, kur vardarbība pret sievietēm kara laikā pamatā bija tabu tēma, bet, ja tomēr aprakstīta, tad piedēvēta pagāniem, barbariem, musulmaņiem. ${ }^{131}$ Kopīgais šiem aprakstiem - kara nepieciešamības un taisnīguma pamatojums. Arī Dusburgas Pētera hronikā (1326) ar šādu argumentāciju pamatoja Vācu ordeña misijas nepieciešamību Prūsijā. ${ }^{132}$

Atriebības kara tēma citā ideologiskā griezumā izskan Vācu ordeña herolda Marburgas Vīganda hronikā (1394): igauṇu 
1343. gada sacelšanās bija taisnīga atriebība par sieviešu izvarošanu. Vācu bruṇinieki un vasal̦i apkaunoja igauņu sievas, izvaroja meitas, atņēma viņiem îpašumu un izturējās pret tiem kā pret vergiem. ${ }^{133}$ Hronika parāda laikmetam raksturīgu uzskatu par tiešu saistību starp vīriešu godu un sieviešu apkaunojumu, kā arī tiesības un pienākumu nodarījumu atriebt, lai gan vin,a iespējamajā avotā - Honekes hronikā - igauṇu uzsāktā kara iemesli netiek tieši saistīti ar "sieviešu jautājumu". ${ }^{134}$

Honekes hronikā par tirāniju dēvēts pleskaviešu iebrukums Gaujienas novadā 1341. gadā, ko raksturo sagūstīto sieviešu nogalināšana, izvarošana, krūšu nogriešana. Šajā hronikā tirāniska rīcība piedēvēta arī livoniešiem pilsoṇu kara laikā starp ordeni un Rīgu (1297-1330): rīdzinieki ne tikai nodedzinājuši Daugavgrīvas miestu, kur mira daudzas sievietes ar maziem bērniem rokās, bet arī metuši sievietes, bērnus un vīriešus alus gatavošanas pannās. Līdzīgs nodarījums - Tērvetes miesta nodedzināšana kopā ar ordeņa brāliem, vīriešiem, sievietēm, bērniem - piedēvēts lietuviešiem (1346). ${ }^{135}$

15. gadsimtā un 16. gadsimta sākumā sieviešu aizstāvība kā arguments taisnīgas cinnas pamatojumam tika izmantots Vācu ordeña Livonijas atzara apologijā, lai konsolidētu spēkus karam pret austrumu kaimiņiem. Livonijas mestra vēstulē virsmestram 1480. gada 25. martā pleskaviešu un vinu sabiedroto uzbrukums aprakstīts ar visdrūmākajām detạ̄ām: krievi (pleskavieši), kuri sabiedrojās ar tatāriem, esot uzšķērduši grūtnieces un nedzimušos zīdaiņus sprauduši uz mietiem. Viṇi nogriezuši sievietēm krūtis, nogalinājuši, izvarojuši, aizveduši tās gūstā, arī jaunavas. ${ }^{136}$ Līdzīgos izteicienos krievu karagājienu Livonijā apraksta Lībekas rātes hronikas autors, attiecinot krievu uzbrukumu uz 1480. gadu un traktējot to kā Dieva sodu orden,a kungiem par Rīgas arhibīskapa un domkungu sagūstīšanu. ${ }^{137}$ No pētījumiem par "krievu briesmu" atspoguḷojumu Vācu ordeņa retorikā secināms, ka austrumu kaimiņa apsūdzību Livonijas zemeskungi aktīvi izmantoja kā politisku instrumentu gan starptautiskajā, gan Livonijas iekšpolitiskajā diskursā, t. i., ar tēmu manipulēja. ${ }^{138}$ Pie "krievu briesmām" piederēja arī vardarbība pret Rietumu kristiešiem, ìpaši pret sievietēm un bērniem.

Var minēt, ka vienlaikus ar ordeña retoriku sieviešu aizstāvība parādās kā viens no argumentiem pareizticīgo "taisnīgam karam" pret livoniešiem. Pleskavas hronika 1480.-1481. gada notikumus attēlo kā svēto karu pret senseniem ienaidniekiem. Pleskaviešiem bija jāaizsargā sava zeme un jāatriebjas "pagāniem vāciešiem" par kristiešu asiṇu izliešanu, jāaizstāv sievas un bērni, kuri tiek vesti gūstā. Pleskavas hronikas fiksē daudzus savus un livoniešu sirojumus iepriekšējos gados un gadsimtos, akcentējot sieviešu gūstīšanu kā gandrīz pašsaprotamu karu sastāvdaḷu, bet par šo karagājienu 1480. gada februārī-martā teikts, ka pleskavieši nogalināja daudzus Livonijas vìriešus, sievietes un bērnus, "un Dievs vienmēr palìdzēja lielkņaza vojevodām un pleskaviešiem, un viñi atriebās vāciešiem divdesmitkārtigi vai vairāk". Vienlaikus pareizticīgais hronikas rakstītājs nejūsmoja par sirošanu, baznīcu izlaupīšanu, izvarošanu un sieviešu un vīriešu gūstišanu, kas piedēvēta pleskaviešu sabiedrotajiem Maskavas kṇaza brāliem Andrejam un Borisam. ${ }^{139}$

Livonijas kara laikā tatāru un maskaviešu sirojumu apraksti bija pārpilni ar vardarbības ainām pret livoniešiem, arī vācu sievietēm, ar izvarošanu, nogalināšanu, mocīšanu. Vardarbības apraksti veicināja sabiedroto un jaunu zemes kungu meklēšanu kaimiņu karalistēs, nevis vēlmi padoties Maskavas lielkṇaza varai. Maskavas lielkṇaza argumentācija par taisnīgu karu pret Livoniju 16. gadsimta vidū un otrajā pusē neietvēra "sieviešu jautājumu", 
bet gan izvirzīja centrā nodevību un līgumu neievērošanu, ${ }^{140}$ kā arī pareizticīgo cinnu pret k̦eceriem (luterāṇiem) - Livonijas vāciešiem. ${ }^{141}$

Ja uzdod jautājumu, vai un kā mainījās karošanas veids un kā mainījās karotāju attieksme pret civiliedzīvotājiem jauno laiku sākumā, jāatzīmē, ka Livonijas kara sākotnējos sirojumos nebija būtiski jaunu iezīmju. 1558.-1559. gadā karagājienā galvenais krievu karapulks lēni virzijjās ienaidnieka teritorijā no tradicionālās karaspēka pulcēšanās vietas Pleskavā, uz visām pusēm sūtot nelielas jātnieku vienības. Tās varēja bez kādiem ierobežojumiem sirot, postīt, ņemt gūstekṇus, dedzināt un laupīt. Šāda sirojuma mērḳis nebija teritorijas iekarošana. Būtisks bija kara laupījums, kā arī pretinieka iebaidīšana. ${ }^{142}$ Vardarbība sirojuma laikā tātad bija leǵitīma, akceptēta, taču tā tāda bija, jādomā, arī iepriekšējos sirojuma karos, jo daudzus gadsimtus karagājieni tika raksturoti īsi - "laupīja un dedzināja". Jauns akcents livoniešu aprakstos par ìpaši nežēlīgu karavīru attieksmi pret sievietēm ir tatāru un maskaviešu klātbūtne, ${ }^{143}$ kas lika arī novgorodiešu karaspēkam darboties "efektīvāk". ${ }^{144}$ Livonijas kara vēlākajos posmos Kazaņas un citu dienesta tatāru klātbūtne Livonijas karagājienos kḷuva vēl pamanāmāka. Izpratne par īpašām kristiešiem raksturīgām patvēruma vietām vai sabiedrības grupām, kuras vajadzētu saudzēt, viniiem bija sveša. Tā garīdznieks Brakels apraksta notikumu Sāremā krievu iebrukuma laikā 1576. gadā. Zemnieki, viṇu sievas un bērni centās no maskaviešu uzbrukuma paglābties Pihu baznīcas tornī, bet ienaidnieki ar zobenu un uguni visu izpostīja, netaupot ne grūtnieces, ne bērnus. ${ }^{145}$ Dionīsija Fabrīcija hronikā maskaviešu karaspēkā minēti "skiti un barbari”, kuri nogalināja dižciltīgos, izvaroja viņu sievas un meitas. ${ }^{146}$ Jērnes hronikā ir vairāki apraksti ne tikai par sieviešu izvarošanu, grūtnieču uzšķēršanu u. c., pie tam, aprakstot Aizkraukles ieņemšanu 1577. gadā, ziņots, ka karaspēka vadītājs krievu lielkṇazs lika tatāriem sievietes dižciltīgo acu priekšā izvarot un pēc tam vilkt pa zemi. ${ }^{147}$ Aizkraukles iekarošana arī Reinholda Heidenšteina aprakstā attēlota vienkāršākiem vārdiem - sievietes atdeva kā gūsteknes tatāriem. ${ }^{148}$ To var skaidrot arī visai racionāli kā kara laupijuma daḷas izmaksu. ${ }^{149}$ Tāpat daudz detaḷu par karagājieniem ir Rennera hronikā, kas reizi pa reizei karagājiena aprakstos izcel kādas īpašas darbības pret sievietēm, piemēram, Ēróemē pēc pils ienemšanas 1560. gadā tika pakārtas vairākas sievietes, bet Vecpērnavā vairākas vācu sievietes tika pakārtas kokos, un vinu apgēerbu rotājumi no sudraba un zelta norauti. ${ }^{150}$ Vēl cits faktors ir saistīts ar Maskavas cara Ivana IV Bargā metodēm valsts pārvaldē, kas Krievzemē pēc 1564. gada paredzēja gan plašas iedzīvotāju deportācijas, gan teroru un vardarbību pret daudzām iedzīvotāju grupām. 1577. gada karagājiena laikā cars uzskatīja Livoniju par jau iekarotu, savu teritoriju, un vardarbība bija vērsta pret padotajiem, īpaši tika sodītas pilsētas un pilis, kuras bija zvērējušas uzticību "Livonijas karalim" Magnusam. ${ }^{151}$

Pat ja pienem, ka maskaviešu piedēvētajā mežonībā varētu būt daḷa sava laika stereotipu un apraksti ir pārspīlēti, nav šaubu, ka 16.-17. gadsimta kari bija nežēlīgi, un karaspēka darbības pretinieka iebaidīšanai ietvēra sankcionētu kara vardarbību sirojuma laikā, zemes izpostǐšanu, kā arī ienaidnieka sieviešu pazemošanu un seksuālu vardarbību. Vispārzināmās kara ainas kḷuva par argumentu cīṇai, bēgšanai vai arī kolektīvai pašnāvībai, kas Cēsīs aprakstīta saistībā ar 1577. gada notikumiem Rennera, Rusova, Heninga hronikās, kā arī krievu avotos, jo pilsētas aizstāvji labāk uzspridzinājās, nevis nonāca Maskavas cara gūstā. ${ }^{152}$ Arheolog̣iskie atradumi Cēsu pilsdrupās ir unikāla liecība par kara 
notikumiem un rāda arī vairāku jaunu sieviešu bojāeju kādā no pils pagrabiem, ticamākais, krievu karaspēka uzbrukuma laikā. Viṇu nāvi palīdz datēt monētu atradumi. ${ }^{153}$

Livonijas sabiedrības virsslānī tieši vardarbība pret vācu un dižciltīgajām sievietēm izraisīja šausmas, un vācu sieviešu nogalināšana, ievainošana, jo īpaši izvarošana, tika attēlota kā mežonība, barbarisms, kas vērsts pret Rietumu kristietēm. Iespējams, te vērojams iespaids arī no germāṇu tautu morāles un ticējumiem. Varbūt der atcerēties Johana Agrikolas vārdus: "Kas apkauno jaunavu, mirst sliktā nāve "? Vai arī itāḷ humānista Pikolomini (Aeneas Silvius Piccolomini, ? -1464), vēlākā pāvesta Pija II, apgalvojumu, ka vācu karavīri, atškiirībā no citām tautībām, esot pārliecināti, ka izvarošana ir milzīgs grēks, tādēḷ pēc pilsētu iekarošanas Itālijā sievietes nepiedzīvoja seksuālu vardarbību. ${ }^{155}$ Katrā ziṇā viduslaikos un vēl 16. gadsimtā, piemērojot īpašus miesas sodus sievietēm, darbojās vācu pilsētnieku un laucinieku māṇticība par sieviešu ķermeņa apgānīšanas sekām, pat ja tas no mūsdienu viedokḷa ir zināms paradokss. Piemēram, dzīvas noziedznieces ierakšana zemē, noslīcināšana, sadedzināšana tika uzskatīta par sievietēm piemērotiem sodiem, jo tad k̦ermenis pēc nāves nenonāca publiskai apskatei. Dažādu vācu tiesību hronikas stāsta par gadījumiem, kad pilsētās pirmo reizi sievietēm piemēroja nāves sodu pakarot. Kad 1584. gadā Nirnbergā tika pakārtas divas sievietes, kuru līki, kā jau ierasts, atradās pie karātavām ilgāku laiku, tas bija sensacionāls un pirmreizējs notikums. ${ }^{156}$ Vienlaikus jāatzīmē, ka viduslaiku un agro jauno laiku cilvēkiem izpratne par taisnīgu vardarbību bija ikdiena. Tā uzduršana uz mieta jeb pāḷa viduslaikos piederēja pie visai izplatītiem soda veidiem, ko dažviet vācu zemēs attiecināja arī uz sievieti, savukārt zīdaiṇu nogalināšana un krūšu nogriešana visai detalizēti attēlota šā laika sakrālajā mākslā. Piemēram, ainas ar svētās Barbaras, Katrīnas, Agates mocīšanu baznīcu altārgleznojumos bija īpaši populāras vācu pilsētās Baltijas jūras reǵionā un liecina par šo mākslas darbu autoru un arī to skatītāju pārliecību par nekristiešu rīcību pret patiesām kristietēm, ar kurām asociēja vācu sievietes. ${ }^{157}$

Livonijas kara laikā arī zemnieku mežonība raksturota ar vēršanos pret dižciltīgām vācu sievietēm. Rusovs stāsta, ka 1560. gadā zemnieki Harjumā un Lēnemā nogalinājuši dižciltīgas sievietes, un arī Livonijas mestra Ketlera vēstulē poḷu karalim 1560. gada 8. oktobrī teikts, ka igauņu zemnieki esot dažus muižniekus nokāvuši, daudz rētu iecirtuši pat dažām sievietēm (matronis); savukārt hercogs Magnuss 1560. gada 13. oktobrī Kuresārē Dānijas karalim raksta:

“mūsu pašu [...] zemnieki ir jau paspējuši nosist dažus no muižniekiem [...]; viñi ari nežēligā kārtā nokāvuši sievas, jaunavas un bērnus un trakojuši, un plosijjušies [...]". ${ }^{158}$

Vardarbība pret sievietēm un argumenti par labāku aizstāvību Livonijā aktualitāti ieguva 17. gadsimta sākumā polemikā starp zviedru un poḷu pusēm, kuras aicināja livoniešus uz cīṇu vai arī mudināja mainīt politisko piederību. Ārkārtīga nežēlība, tai skaitā pret dižciltīgajām vācu sievietēm, tika piedēvēta poļu-lietuviešu karapulkiem. Livoniešu ziņojumā zviedru karalim 1599.-1602. gadā apgalvots, ka 1601. gadā, poḷu-lietuviešu karaspēkam karaḷa Sigismunda III (Zygmunt III Waza) vadībā ejot caur Kurzemi, tika izpostīti 16 Kurzemes hercogistes iecirkṇi, īpaši vēršoties pret vācu muižniekiem. Kāda 80-gadīga sieviete tikusi mocīta, daudzus vīriešus izgèrba kailus, citus pa pusei ieraka zemē un tad sāka apšaudīt. Izvarošana esot kḷuvusi par tik pašsaprotamu parādību, ka karavīri to neuzskatījuši par grēku, bet ar to pat lielījušies. Dižciltīgus laudis bieži 
piesēja pie staba, to sievas un bērnus viņu acu priekšã izvaroja; dažiem viṇi pat nenovēlēja nāvi, pēc kuras tie būtu ilgojušies, bet palaida valāa ar nogrieztām ausīm un degunu. Vidzemē savukārt kopā ar poliiem karojuši arī tatāri, kuri atkal vainoti sieviešu, bērnu, grūtnieču nogalināšanā dažādos veidos, bet arī poḷi esot nogalinājuši bērnus un sievietes veidā, kam var piedēvēt rituālas vardarbības raksturu: 1601. gadā Daugavā esot noslīcināti ap 2000 iedzīvotāju, tai skaitā daudz mazu bērnu, tiem iepriekš nocērtot rokas. ${ }^{159}$

Zviedru hercoga Kārḷa (1550-1611) aicinājumā padoties zviedru kundzībai 1601. gada 3. martā poḷi un lietuvieši apvainoti sieviešu un bērnu sagūstīšanā, izvarošanā un nogalināšanā gímenes vīriešu acu priekšā, ko var uzskatīt par klaju zviedru propagandu, taču pat Polijas-Lietuvas valdniekam simpatizējoši autori bija spiesti konstatēt karaspēka vardarbību. ${ }^{160}$ Dionīsijs Fabrīcijs, kurš savā hronikā cildina Žečpospoḷitas karaspēka uzvaras, tomēr norāda ne tikai uz zviedru vardarbīgu izturēšanos pret Livonijas sievietēm (dižciltīgām un nebrīvajām) bet arī uz poḷu-lietuviešu karaspēka varmācību un laupišanu. Savstarpējā sarakstē starp Livonijas kārtām un zviedru, kā arī poḷu sūtniiem par padošanos 1601. gadā vācu un nevācu sieviešu aizsardzība pret varmākām ir viens no pamata argumentiem. Rīgas rātes un amatvīru atbildē poḷu virsniekam Jirgenam Fārensbaham (Jürgen von Fahrensbach, 1551-1602), kurš aplenca pilsētu 1601. gadā, nevēlēšanās padoties poḷiem tika pamatota arī ar viņu piekopto sieviešu izvarošanu. Tāpat Rēzeknes dižciltīgo vēlme padoties zviedriem balstījās uz poḷu nežēlību: Rēzeknes stārasts niknumā esot nositis 11 zemniekus līdz ar sievām un bērniem, un arī Tērbatas bruṇniecības pārstāvji rakstā hercogam
Kārlim 1602. gada jūnijā apgalvoja, ka poḷi bijuši ìpaši nežēlīgi pret zemniekiem, viṇu sievām un bērniem. Tomēr ir arī apvainojumi zviedriem: poḷi uzsaukumā livoniešiem ap 1602. gada februāri aicināja pasargāt sievietes un bērnus, pret kuriem zviedru karavīri izturoties nežēlīgi. ${ }^{161}$

Par sievietēm kā kriminālu noziegumu upuriem un arī par civilistiem kā kara upuriem Rietumeiropas viduslaiku un agro jauno laiku militāros konfliktos ir daudz pētījumu, kuri nonāk pie visai dažādiem secinājumiem saistībā ar karu un sievietēm kā upuriem. Var domāt, ka, zaudējot aizbilstamās statusu, sieviete arvien vairāk parādījās publiskās vietās, iesaistījās konfliktos, tāpēc pieauga informācija par nogalinātām un izvarotām sievietēm. Sievietes tika biežāk sodītas par pastrādātajiem noziegumiem, dažādos krimināla rakstura konfliktos 17.-18. gadsimtā būtiski pieauga sieviešu kā vardarbības upuru skaits. Iespējams, mainījās morāles pamatnostādnes par sievietes dzīvības saudzēšanu un dažādu vēstures avotu autoru nostāja vardarbības attēlošanā. Agrāk to vairāk noklusēja, bet jauno laiku sākumā pat īpaši izcēla, smeḷot sižetus ne tikai no Vecās Derības, bet arī antīkajām teikām, vēsturnieku Hērodota (ap 480.-425. p. m. ē.), Tita Livija (64./59. g. p. m. è. - 12/17) u. c. darbiem, kuros līdzīgi kā 16. gadsimta beigās un 17. gadsimtā kādas teritorijas iekarošana un pakḷaušana nozīmēja tās attīrīšanu no nevēlamiem iedzīvotājiem (nogalināšana) un jaunas tautas radīšanu, izvarojot iekarotās zemes sievietes. Sievietes saudzēšana miera un kara laikā - vai tās pamats būtu Dieva miers un kristīgā morāle vai tradicionālajai tautas kultūrai un paražu tiesībām raksturīgā sievietes tiesiskā aizstāvība - vairs nepastāvēja pat idealizēta stāsta variantā. 


\section{ATSAUCES UN SKAIDROJUMI}

${ }^{1}$ JAN HOLLING. Internationaler Strafgerichtshof und Verbrechensprävention. Berlin 2016, S. 7-8.

${ }^{2}$ HeINZ-GÜNTHER Stobbe. Religion, Gewalt und Krieg: Eine Einführung (Theologie und Frieden). Stuttgart 2010, S. 245.

${ }^{3}$ James Michael Illston. 'An Entirely Masculine Activity?' Women and War in the High and Late Middle Ages Reconsidered. Canterbury 2009, p. 43; KAREN HAGEMANN. Militär, Krieg und Geschlechterverhältnisse. Untersuchungen, Überlegungen und Fragen zur Militärgeschichte der Frühen Neuzeit. In: Klio in Uniform. Probleme und Perspektiven einer modernen Militärgeschichte der Frühen Neuzeit. Ed. Ralf Pröve. Cologne, Vienna 1997, S. 35-88; SiLKE TAMMEN. Gewalt im Bilde: Ikonographien, Wahrnehmungen, Aestisierungen. In: MANUEL BRAUN, CoRNELIA HERBERICHS (Hg.). Gewalt im Mittelalter: Realitäten - Imaginationen. München 2005, S. 307-340; StоввE, Religion, Gewalt und Krieg, S. 245.

${ }^{4}$ Indriķa hronika / Heinrici Chronicon. Tulk. Ābrams Feldhūns, koment. Ēvalds Mugurēvičs. Rīga 1993 (turpmāk - IH), XIII, 4.

${ }^{5} \mathrm{IH}, \mathrm{XVII}, 3$.

${ }^{6}$ EdVARDAS GudAviČIUS. Lietuvos istorija. I tomas: Nou seniausių laikų iki 1569 metų. Vilnius 1999, p. 35.

${ }^{7}$ IH, VII, 5; XIII, 4.

${ }^{8}$ NiLS Blomkvist. The Discovery of the Baltic. The Reception of a Catholic Word-System in the European North (AD 1075-1225). Leiden, Boston 2005, p. 774.

${ }^{9}$ TORE NYBERG. Skandinavien im Ostseeraum in der Zeit vom 12. bis 14. Jahrhundert. In: Die Christianisierung Litauens im mitteleuropäischen Kontext. Materialien zur internationalen wissenschftlichen Konferenz gewidmet dem 750. Jubiläumsjahr der Taufe des Mindaugas, König von Litauen. Vilnius, Museum für angewandte Kunst, am 26. und 27. September 2001. Vilnius 2005, S. 37-60, hier S. 49; William URBAN. The fronter Thesis and the Baltic Crusade. In: Crusade and conversion on the Baltic frontier, 1150-1500. Ed. by Alan Murray. Burlington 2001, pp. 50-51.

${ }^{10} \mathrm{IH}, \mathrm{XVIII}, 4$.

${ }^{11} \mathrm{IH}, \mathrm{XV}, 13$; XVI, 7; XVII, 4, 6; XVIII, 1, sk. arī 3. piezīmi 356. lpp.

${ }^{12} \mathrm{IH}, \mathrm{XXVIII,} 8$.

${ }^{13}$ Liv-, Esth- und Curländisches Urkundenbuch nebst Regesten. Hrsg. von Friedrich Georg von Bunge. Abt. I, Bd. 1. Reval 1853, Nr. 390.

${ }^{14}$ Ibidem, Nr. 468; 469; PAUl JOHANSEN. Nordische Mission, Revals Gründung und die Schwedensiedlung in Estland. Stockholm 1951, p. 36; ARTUR VASSAR. Istorija Estonskoj SSR v treh tomah. Tom 1: S drevneis'ih vremj'on do serediny 19 veka. Tallinn 1961, s. 214.

${ }^{15}$ IBEN Fonnesberg-Schmidt. The Popes and the Baltic Crusades 1147-1254. Leiden, Boston 2007, p. 287.

${ }^{16}$ Heinrich Unverhau. Margarethe Sambiria von Pomerellen. In: Neue Deutsche Biographie 16, 1990, S. 157. Pieejams: http://www.deutsche-biographie.de/ppn137338767.html (skatīts 10.06.2015.).

${ }^{17}$ EDVARD RYMAR. Rodowód książąt pomorskich. Gdańsk 2003, pp. 75-76; ALEKSANDER MAJKOWSKI. Historia Kaszubów. Gdańsk 1991, p. 133.

${ }^{18}$ SANita Osipova. Viduslaiku tiesību spogulis. Rīga 2004, 127. lpp.; SHULAMith ShahAR. The Fourth Estate: A History of Women in the Middle Ages. London, New York 2003, p. 128.

${ }^{19}$ FrIEDRICH GEORG vON BUNGE (Hg.). Altlivlands Rechtsbücher. Leipzig 1879, S. 17, 22, 25, 29 , $32,38,61-64,66,78$.

${ }^{20}$ ASTAF TRANSEHE. Stadtbürger als Lehnsleute des livländischen Adels. Jahrbuch für Geneologie, Heraldik und Sphragistik 1899. Mitau 1901, S. 1-19, hier S. 19. 
${ }^{21}$ AleXANDeR BeRgegrüN. Herzog Christoph von Mecklenburg, letzter Koadjutor des Erzbistums Riga. Ein Beitrag zur livländischen und mecklenburgischen Geschichte. Reval 1898, S. 183-185. Var minēt, ka Kristofs galu galā apprecēja šo sievieti, tiesa, pēc krietna laika un jau pavisam citā statusā - kā atraitnis un Raceburgas bīskapijas pārvaldnieks.

${ }^{22}$ Theodor Kallmeyer (Hg.). Salomons Henning's Lifflendische Churlendische Chronica von 1554 bis 1590 und Bericht in Religionssachen. Riga 1857, S. 54.

${ }^{23}$ Herzog Albrecht von Preußen und Livland (1565-1570). Regesten aus dem Herzoglichen Briefarchiv. Bearb. von Stefan Hartmann. Köln, Weimar, Wien 2008 (Veröffentlichungen aus den Archiven Preußischer Kulturbesitz, 63), Nr. 3429, 3438-3439.

${ }^{24}$ EdGARS DunSDORFS, ARNOLDS SPEKKE. Latvijas vēsture 1500-1600. [Stokholma] 1964, 156. lpp.

${ }^{25}$ ANDRIS ZEL̦ENKovs. Dānijas prinča Magnusa (1540-1583) darbība Livonijā. In: Latvijas Kara muzeja gadagrāmata. Rìga 2000, 15.-30. lpp.

${ }^{26}$ VAlENTIN JANin (ed.). Jerome Horsey. Sapiski o Rossii. Moskva 1990, s. 179; DunSDorfs, SPEKKE, Latvijas vēsture 1500-1600, 160. lpp.

${ }^{27}$ TAtJAna Oparina. Probl'ema istoc'nikov deportacij livonskih plennikov v Rossiji. In: Baltijskij vopros v konce XV-XVI v. Moskva 2010, s. 239-268, here s. 246.

${ }^{28}$ KALlmeYeR, Salomons Henning's Lifflendische Churlendische Chronica, S. 90; JANIN, Jerome Horsey, s. 94-96. Marija esot teikusi angḷu diplomātam Horsejam, ka vinu tur gūstā un cer izmantot dižciltīgās asinis, it kā vina būtu kāda êgiptiešu dieviete.

${ }^{29}$ FrIEDRICH BIENEMANN (Hg.). Briefe und Urkunden zur Geschichte Livlands in den Jahren 1558-1562. Aus inländichen Archiven. Bd. 3. Riga 1868, S. 117-123, Nr. 470-472.

30 Richard Hausmann, Konstantin HÖHLbaum (Hg.). Johann Renner's Livländische Historien (1582). Göttingen 1876, S. 247-249.

${ }^{31}$ INDRIĶIS ŠTERNS. Latvijas vēsture 1290-1500. Rīga 1997, 395. lpp.

${ }^{32}$ VIJA STIKĀNE. Lauku sabiedrības sieviete sabiedriskajā sfērā viduslaikos un jauno laiku sākumā. In: Latvijas Vēstures Institūta Žurnāls 2001, Nr. 4, 63.-83. lpp.

${ }^{33}$ ARVEDS ŠVĀBE (izd.). Vidzemes saimniecības vēstures avoti 1553-1618. Rīga 1941, 46. lpp.

${ }^{34}$ LEONID ARBusow (Hg.). Liv-, Est- und Curländisches Urkundenbuch. Abt. 2, Bd. 1. 1494 Ende Mai - 1500. Riga, Moskau 1900, Nr. 468.

${ }^{35}$ August von BulmeRINCQ. Zwei Kämmerei Register der Stadt Riga. Ein Beitrag zur Deutschen Wirtschaftsgeschichte. Leipzig 1902, S. 156, 190.

${ }^{36}$ Alfred Ritscher. Reval an der Schwelle zur Neuzeit. Teil 1: Von Vorabend der Reformation bis zum Tode Wolters von Plettenberg (1510-1535). Bonn 1998, S. 232.

${ }^{37}$ Sk. ari: RASA MAZEIKA. Nowhere was the Fragility of their Sex Apparent: Women Warriors in the Baltic Crusade Chronicles. In: AlAN MurRAy (ed.). From Clermont to Jerusalem: The Cursades and Crusader Societies 1095-1400. Turnhout 1998, pp. 229-248.

${ }^{38} \mathrm{IH}, \mathrm{XXIII}, 9$.

${ }^{39}$ Atskaņu hronika / Livländische Reimchronik. Tulk. Ēvalds Mugurēvičs, Ēvalda Mugurēviča un Kaspara Kḷaviņa komentāri. Rīga 1998 (turpmāk - AH), 1933., 1279.-1331. rinda.

${ }^{40}$ Vartberges Hermaņa Livonijas hronika. Ēvalda Mugurēviča tulkojums, priekšvārds, komentāri. Rìga 2005, 80.-81. lpp.

${ }^{41}$ Konstantin HÖLbaum (Hg.). Die jungere Livländische Reimchronik des Bartholomeus Hoeneke 1315-1348. Leipzig 1872, S. 20; HAUSMANN, HÖHLBAuM, Johann Renner's Livländische Historien, S. 87; DUNSDORFS, SPEKKE, Latvijas vēsture 1500-1600, 140. lpp.

${ }^{42}$ ARNOLDS SPEKKE. Daži veci tiesu protokoli par zemnieku nemieriem 1586. un 1586. g. In: Izglïtības Ministrijas Mēnešraksts 1932, Nr. 2, 102.-104. lpp., šeit 104. lpp.

${ }^{43}$ VitaliJ PenskoJ. Oc'erki istoriji Livonskoj voiny: ot Narvy do Fellina, 1558-1561. Moskva 2017, s. 82. 
${ }^{44}$ GeORg FrIEDRICH vON Bunge (Hg.). Monumenta Livoniae Antiqua. Sammlung Chroniken, Berichten, Urkunden und andern Schriftlichen Denkmalen und Aufsätzen. Bd. 1. Th. Hiärn's Ehst-, Lyf- und Lettländische Geschichte. Riga, Dorpat, Leipzig 1835, S. 332.

${ }^{45}$ VASSAR, Istorija Estonskoj SSR v treh tomah, s. 244; SUlEv VAHTRE. Die Darstellung des Estenaufstandes 1343 bis 1345 in Deutschordenschroniken. In: BERNHARD JAHNIG, KLAUS Militzer (Hg.). Aus der Geschichte Alt-Livlands. Festschrift fur Heinz von zur Muhlen zum 90. Geburtstag. Münster 2004, S. 55-69. Pēc līdzīga stāsta izskatās arī Atskaṇu hronikā minētā epizode, kur aprakstīta laba pagānsieva Emme. Viņa ar vīra ațauju gājusi pie gūstekṇiem Vīlandes pilī un metusi viniem ar akmen,iem. Taču akmeņos bijis ēdiens, kas l̦āvis gūstekṇiem izdzīvot (AH, 777.-798. rinda).

${ }^{46}$ Eugen von NottBeck. Die alte Criminalchronik Revals. Reval 1884, S. 49.

47 AlbeRt BAuer (Hg.). Akten und Rezesse der livändischen Ständetage. Bd. 2, Lief. 1. 1460-1467. Riga 1934, S. 160, Nr. 230; sk. arī: MARINA BESSUDNOVA. Deistvija razvedyvatel'noj sluz'by Livonskovo ordena v predelah russkh zemel' na rubez' XV-XVI vekob. In: Baltijskij vopros v konce XV-XVI v. Moskva 2010, s. 17-19, here s. 27.

${ }^{48}$ DUNSDORFS, SPEKKE, Latvijas vēsture 1500-1600, 139. lpp.

${ }^{49}$ FrIEDRICH BIENEMANN (Hg.). Briefe und Urkunden zur Geschichte Livlands in den Jahren 1560-1561. Aus in ländichen Archiven. Bd. 4. Riga 1873, Nr. 715.

50 Ēvalds MugurĒvičs (izd.). Dionīsija Fabrīcija Livonijas vēsture / Dionysii Fabricii Livonicae Historiae. Rìga 2016, 219. lpp.

${ }^{51}$ JULIA KNÖDLER. Vergewaltigung und Krieg im Mittelalter. Themenschwepunkt Krieg im Mittelalter. Hg. von Arbeitskreiz Militärgeschichte e. V. Jg. 10. 2005, Nr. 2, S. 22-26; HANNELORE ZUG TUCCI. Kriegsgefangenschaft im Mittelalter. Probleme und erste Forschungsergebnisse. In: Krieg im Mittelalter. Hg. von Hans-Henning Kortüm. Berlin 2001, S. 127.

${ }^{52}$ KNÖDLER, Vergewaltigung und Krieg, S. 22-26.

${ }^{53}$ LEOPOLD AUER. Formes des Krieges im abendländiscen Mittelalter. In: MANFRIED RAUCHENSTEINER, ERWIN A. SCHMidL (Hg.). Formen des Krieges. Vom Mittelalter zum "LowIntensity-Conflict". Gratz 1991, S. 17-43, hier S. 19, 28.

${ }^{54}$ GABRIELA SignORI. Frauen, Kinder, Greise und Tyrannen. Geschlecht und Krieg in der Bilderwelt des späten Mittelalters. In: KLAus SchreINer (Hg.). Bilder, Texte, Rituale. Wirklichkeitsbezug und Wirklichkeitskonstruktion politisch-rechtlicher Kommunikationsmedien in Stadt- und Adelsgesellschaft des späten Mittelalters. Berlin 2000, S. 139-164.

${ }^{55}$ HOLLING, Internationaler Strafgerichtshof und Verbrechensprävention, S. 7-8. Karalis Rihards II Anglijā 1386. gadā apsūdzēja savus karavīrus vardarbībā pret sievietēm un garīdzniekiem, dzīvojamo māju dedzināšanā un baznīcu aplaupišanā. Apsūdzētos sodīja ar nāvi. Savukārt par brutalitāti pret iedzīvotājām militāra konflikta laikā, arī par izvarošanu un pavēlēm nogalināt iedzìvotājus 1474. gadā starptautiskā kara tiesa Braizahā pie Reinas notiesāja Pēteri fon Hāgenbahu.

${ }^{56}$ Sk. ViJA STIKĀNE. Sievietes tiesiskais statuss viduslaikos un jauno laiku sākumā. In: Latvijas Vēstures Institūta Žurnāls 2002, Nr. 4, 35.-55. lpp.

${ }^{57}$ MARIA KoczersKA. Recht der Frau, Ostmitteleuropa. In: Lexicon des Mittelalters. Hg. u. Berater ROBERT-HENRY BAUTIER. Bd. IV. München, Zürich 1989, Kolumne 861-864; INGĖ LUKŠAITĖ. Ob obyc'aje dvojnovo vykupa za z'ens'c'inu po Litovskomu pravu. In: Sovetskaja Etnografija. Tom. 2. Moskva 1968, s. 114-120.

${ }^{58}$ GUNITA ZARIN̦A. Latvijas iedzīvotāju paleodemogrāfija 7. g. t. pr. Kr. - 1800. g. Rīga 2009, 78. , 82. lpp.

${ }^{59}$ Piem.: Liv-, Esth- und Curländisches Urkundenbuch nebst Regesten. Abt. I, Bd. 1, Nr. 242; ANTI SELART. Slavery in the Eastern Baltic in the $12^{\text {th }}-15^{\text {th }}$ Centuries. In: SIMONETA CAVACIOCCHI (ed.). Schiavitu e servaggio nell'economia europea secc. XI-XVIII [Serfdom and Slavery in the Europan Economu $11^{\text {th }}-18^{\text {th }}$ centuries]. Firence [2014], pp. 351-364, here p. 356. 
${ }^{60}$ EnN TARVEL. Gesellschaftsstruktur in Estland zu Beginn des 13. Jahrhunderts. In: The Feudal peasant in the Eastern and Northern Europe. Tallin 1983, S. 157.

${ }^{61}$ Par ordeņbrāḷ ķīniekiem saukti lietuviešu bērni, sievietes, pat lopi (AH, 3032.-3035. rinda).

${ }^{62}$ VAlentina OHotnikova (ed.). Skazan'ija o Davmonte. In: Biblioteka literatury Drevn'ei Rusi. Tom 6. XIV - seredina XV veka. Sanktpeterburg 1999, s. 56-63, here s. 57.

${ }^{63}$ Vartberges Hermana Livonijas hronika, 113., 116. lpp.

${ }^{64}$ MAKSIM MoISEev. Prisoners of Livonian War in the East: peoples and fates. In: Vēsture: avoti un cilvēki. XXI. Daugavpils 2018, pp. 261-267; OpARINA, Probl'ema istoc'nikov deportacij livonskih plennikov, s. 239-268.

${ }^{65}$ Piem.: Hausmann, HöHlbaum, Johann Renner's Livländische Historien, S. 230; BalthasaR Russouw. Chronica der Provintz Lyfflandt. Barth 1584, S. 123.

${ }^{66}$ ANNA HoROs'KEVIC'. Rossija v sisteme mez'dunarodnyh otnos'enij seredeny XVI v. Moskva 2003, s. 215-223, 230-257, 407-408, 417-420.

67 ŠVĀBE, Vidzemes saimniecības vēstures avoti, 319., 333. lpp.

${ }^{68}$ PAUl VON UNGERN-STERnBERG (Hg.). Urkunden zur Geschichte des swedisch-polnischen Krieges aus den Jahren 1600-1627. In: Sitzungsberichte der Gesellschaft für Geschichte und Altertumskunde der Ostseeprovinzen Russlands zu Riga 1912. Riga 1912, S. 172-204, hier S. 186, Nr. 11.

${ }^{69}$ IH, XI, 5; XII, 6; XVI, 8 u. c.; AH, 906.-910.,1487.-1489., 4126.-4128., 4251.-4271., 4707.-4713., 5961., 6837., 7289.-7295., 9165.-9167. rinda.

${ }^{70}$ Piem.: IH, XXIII, 9.

${ }^{71} \mathrm{IH}, \mathrm{XII}, 6$.

${ }^{72} \mathrm{IH}, \mathrm{XII}, 6$; XVIII, 5.

${ }^{73} \mathrm{IH}$, XXVIII, 5-6.

${ }^{74} \mathrm{AH}, 1269 .-1275$. (igauņi pret letiem un līviem), 1452.-1456. (lietuvieši pret igauņiem un letiem), 1665.-1667. (krustneši pret sāmsaliešiem), 3315.-3319. (bruninieki pret lietuviešiem), 3762.-3764. (sembieši pret Klaipēdas aizstāvjiem), 4251.-4271. (livoniešu apvienotie spēki līvi, leti, kurši, ordeņbrāḷi - pret žemaišiem, akcentējot, ka nogalina tos, kurus nevar paṇemt līdzi kā gūstekṇus), 7046.-7050. (krustneši ien̦em kuršu Kretingas pili), 8040.-8044. (ordeņbrāli pret zemgaḷu Mežotnes pili), 9148.-9164. (ordeņbrāḷi pret zemgaḷu Dobeles pili), 11255.-11256. (ordeņbrāli pret neapbrunotiem Sidrabes zemgaliem) rinda.

${ }^{75}$ AH, 5966.-5975., 6875., 8034.-8038., 11600. rinda.

${ }^{76}$ Šādu jautājumu uzdod vairāki autori, īpaši Džons Džilingems, Alans Marijs. Sk. referāta tēzes: TORBEN KJERSGAARD NIELSEN. Women and Children as Victims of the Baltic Crusades - a case of 'ritual Violence'? International Medieval Congress, Leeds, Juli 2017.

77 BuRnam W. REYnolds. The Prehistory of the Crusades Misionary War and the Baltic Crusades. London, New York 2016, p. $162 \mathrm{ff}$.

${ }^{78}$ Jens SchmeYers. Die Stedinger Bauernkriege. Wahre Begebenheiten und geschichtliche Betrachtungen. Lemwerder 2004, S. 136, 171.

79 STIKĀNE, Sievietes tiesiskais statuss, 35.-55. lpp.

${ }^{80}$ HANNELORE Zug TUCCI. Kriegsgefangene. In: Lexicon des Mittelalters. Hrg. von Robert-Henri Bautlier, Robert Auty, Norman Angermann. Bd. 5. München 1991, Kolumne 1528.

81 John Gillingham. Women, children and the profits of war. In: JANET L. NELSON, SUSAN REYNOLDS, SUSAN M. JOHNS (eds.). Gender and historiography: Studies in the earlier middle ages in honour of Pauline Stafford. London 2012, pp. 61-75.

${ }^{82}$ Thorsten CAPelle. Beute. In: Reallexikon der Germanischen Altertumskunde. Bd. 2. Berlin, New York 1976, S. 323-331. 
${ }^{83}$ Sven EKDAHL. Christianisierung - Siedlung - Litauerreise: Die Christianisierung Litauens als Dilemma des Deutschen Ordens. In: VydAS DolinsKAS (ed.). Die Christianisierung Litauens im mitteleuropäischen Kontext. Materialien zur internationalen wissenschftlichen Konferenz gewidmet dem 750. Jubiläumsjahr der Taufe des Mindaugas, König von Litauen. Vilnius, Museum für angewandte Kunst, am 26. und 27. September 2001. Vilnius 2005, S. 189-205, hier S. $192-193$.

${ }^{84}$ IGOR FroyANOv. Rabstvo i dannicestvo u vostocnih slavjan. Sanktpeterburg 1996, s. 35.

${ }^{85}$ HANS-HENNIG KORTÜM. Kriege und Krieger 500-1500. Stuttgart 2010, S. 243-244; CHRISTOPHER Allmand. War and the Non-Combatant in the Middle Ages. In: MAurice KeEN (ed.). Medieval Warfare: A History. New York 1999, p. 271.

${ }^{86}$ Šādus rituālus vācu viduslaiku karu tradīcijās sk.: GERD ALTHOF. Schranken der Gewalt. Wie gewalttätig war das "finstere Mittelalter"? In: HORST BRUNNER (Hg.). Der Krieg im Mittelalter und in der frühen Neuzeit: Gründe, Begründungen, Bilder, Bräuche, Recht. Wiesbaden 1999, S. 1-24, hier S. 4; NORBERT OHLER. Krieg und Frieden im Mittelalter. München 1997, S. 278.

${ }^{87}$ AH, 6875., 8034.-8038., 11603.-11606. rinda.

${ }^{88}$ EKDAHL, Cristianisierung - Siedlung - Litauerreise, S. 192-193.

${ }^{89}$ Vilho NitTemaA. Die undeutsche Frage in der Politik der livländischen Städte im Mittelalter. Helsinki 1949, p. 44; KLAuss Milicers. Vācu ordeña vēsture. Rīga 2009, 131. lpp.

${ }^{90}$ FrIEdRICH BRUNS (Hg.). Die Chroniken der niedersächsischen Städte: Lübeck. Bd. 5, Teil 1. Leipzig 1911 (Chroniken der deutschen Städte, Bd. 31), S. 244; JAKOB GOTTLIEB LEONHARD NAPIERSKY (Hg.). Die Ouellen des Rigischen Stadtrechts bis zum Jahr 1673. Riga 1876, S. 39.

${ }^{91}$ Tā Koknesē bruṇinieku un Rīgas arhibīskapa vasal̦u Tīzenhauzenu pilī 1382. gadā bijis "gūstekṇu tornis", ko mantinieki nolēma lietot kopīgi; Tartu bīskapijas muižās dreḷıi minēti 1386., 1417. gadā, ordeña vasaḷa Tiepeles muižā - 1419. gadā (HERMAN VON BRUINING, NiKOLAUS BuSCH (Hg.) Livländische Güterurkunden. 1207-1500. Bd. 1. Riga 1908, Nr. 113, 119, 197, 210).

${ }^{92}$ KARL EdUARD NAPIERSKi (Hg.). Russich - livländische Urkunden. St. Petersburg 1868, S. 25-28, Nr. XLIX.

${ }^{93}$ Liv-, Esth- und Curländisches Urkundenbuch nebst Regesten. Hrsg. von Friedrich Georg von Bunge. Bd. 3. I. Nachträge zu den zwei ersten Bänden. II. Fortsetzung von 1368-1393. Reval 1857, Nr. 1111.

${ }^{94}$ Vartberges Hermaņa Livonijas hronika, 107. lpp.

${ }^{95}$ KRIŠJĀNIS BARONS, HENRIJS VISENDORFS. Latvju dainas (turpmāk - LD). 1. sēj. Jelgava 1894, Nr. 7514 (malējiṇa (LD 3843,1); krieviete, kas maizi cep (LD 8118); ARVEDS ŠvĀBE. Kara dziesmas. Latviešu tautas dziesmas. 10. sēj. Kopenhāgena 1956, 373.-378. lpp.

${ }^{96}$ Illston, 'An Entirely Masculine Activity?, p. 99.

${ }^{97}$ Franciska no Moliano izmeklēšanas protokols 1312. gadā / Franciscus de Moliano conscriptio inquisitionis testium 1312. Liecinieku nopratināšana par notikumiem Livonijā 13.-14. gadsimta mijā. Tulk. un koment. Ēvalds Mugurēvičs. Rīga 2010, 231. lpp.

${ }^{98}$ SELART, Slavery in the Eastern Baltic, p. 357.

${ }^{99}$ Ibidem, pp. 351-364; ŠTERnS, Latvijas vēsture 1290-1500, 592. lpp.; RUTH MAZO KARRAS. Slavery and Society in Medieval Scandinavia. New Haven, London 1988, pp. 73-75.

${ }^{100}$ VlAdiMIR Pic'ETA. Obrazcovan'ije belarusskovo naroda. In: Voprosy istorii 1946, Nr. 5-6, s. 3-29.

${ }^{101}$ MoIseEv, Prisoners of Livonian War, pp. 261-267.

102 OpARINA, Probl'ema istoc'nikov deportacij livonskih plennikov, s. 248.

${ }^{103}$ Ibidem, s. 333.

${ }^{104}$ HöLBAUM, Die jungere Livländische Reimchronik, S. 33; Vartberges Hermaṇa Livonijas hronika, 84., 85. lpp. 
105 TheOdoR HiRsch (Hg.). Die Chronik Wigands von Marburg. In: Scriptores rerum Prussicarum. Bd. 2. Leipzig 1863, S. 453-662, hier S. 550.

${ }^{106}$ ARSENiJ NASONOv (red.). Psovskije letopisi. Vypusk vtoroj. Moskva 1955, s. 25.

${ }^{107}$ ARSENIJ NASONOv (red.). Novgorodskaja pervaja l'etopis stars'ego i mlads'ego izvodov. Moskva 1950, s. 4, 45, 74.

${ }^{108}$ NASONOV, Psovskije letopisi, s. 61-62.

${ }^{109}$ LeONid ARbusow (Hg.) Akten und Rezesse der livändischen Ständetage. Bd. 3. 1494-1535. Riga 1910, S. 19, 61, § 21.

${ }^{110}$ Russouw, Chronica der Provintz Lyfflandt, S. 46.

${ }^{111}$ BAUER, Akten und Rezesse, Nr. 230; ARBUSOw, Akten und Rezesse, Nr. 15, 19, 20.

112 BESSUdnova, Deistvija razvedyvatel'noj sluz'by, s. 27.

113 PENSKOJ, Oc'erki istoriji Livonskoj voiny, s. 97-101.

${ }^{114}$ OPARINA, Probl'ema istoc'nikov deportacij livonskih plennikov, s. 267.

${ }^{115}$ MoIseEv, Prisoners of Livonian War, pp. 261-267; OpARINA, Probl'ema istoc'nikov deportacij livonskih plennikov, s. 239-268.

116 PENSKOJ, Oc'erki istoriji Livonskoj voiny, s. 97-101.

117 NASONOV, Psovskije letopisi, s. 24.

${ }^{118}$ MoISEEV, Prisoners of Livonian War, pp. 261-267.

119 KALLMEYeR, Salomons Henning's Lifflendische Churlendische Chronica, S. 31, 32.

${ }^{120}$ Russouw, Chronica der Provintz Lyfflandt, S. 123.

${ }^{121}$ MoIseEv, Prisoners of Livonian War, p. 261.

122 OpArina, Probl'ema istoc'nikov deportacij livonskih plennikov, s. 250.

${ }^{123}$ ANDREJ BEL'JAKOV. Uc'astije mes'c'erskih tatar v Livonskoj voine. In: ALEKSANDR FIL'USKIN (ed.). Baltijskij vopros v konce XV-XVI v. Moskva 2010, s. 227-238, here s. 237; PENSKOJ, Oc'erki istoriji Livonskoj voiny, s. 101, 119.

${ }^{124}$ Herzog Albrecht von Preußen und Livland (1560-1564), Nr. 3142.

125 GotTHARD HANSEN (Hg.). Regesten aus zwei Missivbüchern des XVI. Jahrhunders im Revaler Stadt-Archiv. Reval 1895, Nr. 261.

${ }^{126}$ JĀNIS ZUTIS. Vidzeme kā poḷu un zviedru cīṇas objekts. Rīga 1949, 118. lpp.

${ }^{127}$ HausmanN, HöHLbaum, Johann Renner's Livländische Historien, S. 89; Vartberges Hermaṇa Livonijas hronika, 79. lpp., HÖlBAUM, Die jungere Livländische Reimchronik, S. 20.

${ }^{128}$ Vartberges Hermaņa Livonijas hronika, 79.-80. lpp.

${ }^{129}$ Piemēram, Rīgas dibināšana tika piedēvēta Zobenbrāḷu ordenim, ne Rīgas bīskapam.

${ }^{130}$ SignORI, Frauen, Kinder, Greise und Tyrannen, S. 139-164; KoRTÜM, Kriege und Krieger, S. 243.

${ }^{131}$ NATASHA R. Hodgson. Women, Crusading and the Holy Land in Historical Narrative. Woodbidge 2007, p. 96; KRISTIN SKотTKI. Christen, Muslime und der Erste Kreuzzug. Die Macht der Beschreibung in der mittelalterlichen und modernen Historiographie. Münster, New York 2015, S. 368; OHLER, Krieg und Frieden, S. 274.

132 Vera Matuzova (ed.). Petr iz Dusburga. Hronika zeml'i Prusskoj. Moskva 1997, s. 17-18. Hronikā aprakstīta nekristīto prūšu vardarbība poḷu zemēs: vīrieši tika nogalināti, bet sievietes un bērni aizvesti mūžīgā verdzībā. Gadījās, ka grūtnieces nespēja pārējiem sekot, un tad prūši viņas nogalināja. Prūši esot izrāvuši zīdaiṇus no mātes rokām un nereti nogalinājuši, uzsēdinot tos uz mieta.

${ }^{133}$ HIRSCH, Die Chronik Wigands, S. 505.

${ }^{134}$ Vācieši esot igauṇus mocỉjuši, n̦ēmuši k̦īlniekus, postijjuši viṇu zemi, un par smagu darbu viṇiem nepietika pat maizes. HöLBAUM, Die jungere Livländische Reimchronik, S. 23. 
${ }^{135}$ HöLbaum, Die jungere Livländische Reimchronik, S. 12, 3, 33.

${ }^{136}$ KARL HEINRICH VON BUSSE. Die Feldzüge der Russen in Livland und der Livländer in Russland um das Jahr 1480: Blosse Zusammenstellung von Auszügen aus Chroniken und anderen Geschichtswerken, und von Urkunden, die Sache erläutern (Der Gesellschaft vorgelegt in ihrer Versammlung am 8. Oktober 1847). In: Mittheilungen aus der livländischen Geschichte. Bd. 4, Heft 1. Riga 1847, S. 88-147, hier S. 127-131; ŠTERNS, Latvijas vēsture 1290-1500, 410. lpp.

${ }^{137}$ BRUNS, Die Chroniken der niedersächsischen Städte, S. 243-245.

138 PAUl SRODECKI. "Murus et atemurale pollens et propugnaculum tocius christianitatis." Der Traktatenstreit zwischen dem Deutschen Orden und dem Königreich Polen auf dem Konstanzer Konzil. In: Schweizerische Zeitschrift für Religions- und Kulturgeschichte 2015, Nr. 109, S. 47-65, hier S. 53; MATthiAs ThUMSER. Antirussische Propaganda in der 'Schönen Historie von wunderbaren Geschäften der Herren zu Livland mit den Russen und Tataren'. In: MATTHIAS THUMSER (Hg.). Geschichtsschreibung im mittelalterlichen Livland. Berlin [u. a.] 2011, S. 144; MADIS MAASING. Infidel Turks and Schismatic Russians in Late Medieval Livonia. In: CoRdeLIA He $\beta$, Jonatan AdAMs (ed.). Fear und Loathing in the North: Jews and Muslims in Medieval Skandinavia and the Baltic Region. Berlin, Boston 2015, pp. 346-388; ANTI SELART. Switching the tracks: Baltic cruasades against Russia in the fifteenth century. In: NORMAN HOULSEY (ed.). The Cruasade in the Fifteenth Century: Converting and competing cultures. London, New York 2017, pp. 17ff.

${ }^{139}$ NASONOV, Psovskije letopisi, s. 61-62, 248.

${ }^{140}$ ALEKSANDR FIL'USKIN. Izobretaja pervuju voinu Rossiji i Evropy: Baltijskije voiny vtoroj polovyny XVI v. Glazami sovremennikov i potomkov. Bulanin 2013, s. 112-127, 153.

${ }^{141}$ Ibidem; REINHARD FRÖTSCHNER. Der Livländische Krieg (1558-1582/83) - ein Glaubenskrieg des Moskauer Zartums? Der Krieg im Spiegel der zeitgenössischen offiziellen Moskauer Historiographie. In: BRUNNER, Der Krieg im Mittelalter, S. 373-394.

${ }^{142}$ PenskoJ, Oc'erki istoriji Livonskoj voiny, s. 97.

${ }^{143}$ MugurĒVIČs, Dionīsija Fabrīcija Livonijas vēsture, 173., 177. lpp. (arī skiti un barbari, 157. lpp., arī poḷu sabiedrotie kazaki un tatāri, 203. lpp.).

${ }^{144}$ Ibidem, 123. lpp.

145 MARTIN LindE. Das "Christlich Gesprech" des Tilman Brakel: Untersuchungen zum Weltbild und Geschichtsvertändnis. München 1998, S. 79.

${ }^{146}$ MugurĒVIČs, Dionīsija Fabrīcija Livonijas vēsture, 157., 177. lpp.

147 Bunge, Monumenta Livoniae Antiqua, S. 315.

148 REINHOld Heidens'tein. Zapiski o Moskovskoj voin'e (1578-1582). Sanktpetersburg 1889, s. 4.

${ }^{149}$ BEL'JAKOV. Uc'astije mes'c'erskih tatar, s. 237.

150 Hausmann, HöHlbaum, Johann Renner's Livländische Historien, S. 311, 331.

151 OPARINA, Probl'ema istoc'nikov deportacij livonskih plennikov, s. 245.

152 Ibidem, s. 246.

${ }^{153}$ IEVA OSE. The Livonian War (1558-1583) and the Ruination of Castles, in Particular Kirchholm and Wenden. In: Rainer AtZbach, LaRs MeldgaARd SASS Jensen, Leif Plith Lauritsen (eds.). Castles at War. Bonn 2015, pp. 75-86, here pp. 80-85.

${ }^{154}$ ERNST SCHUBERT. Räuber, Henker, arme Sünder. Verbrechen und Strafe im Mittelalter. Darmstadt 2007, S. 212.

${ }^{155}$ KORTÜM, Kriege und Krieger, S. 241.

156 PETER SCHUSTER. Eine Stadt vor Gericht. Recht und Alltag im spätmittelalterlichen Konstanz. Padeborn, München, Wien, Zürich 2000, S. 223-225.

157 UWE ALBRECHT. Vom wechselvollen Umgang mit Bildern. Ein spätgotischen Katharinenzyklus wird wieder entdeckt. In: KrISTA Kodres, MERIKA KurISOo (eds.). Art and the Church. Religious 
Art and Architecture in the Baltic Region in the $13^{\text {th }}-18^{\text {th }}$ Centuries. Tallin 2008, S. 68-81, here S. 72, 80; TAMMEN, Gawalt im Bilde, S. 321-322.

158 CARL SCHIRREN (Hg.). Quellen zur Geschichte des Untergangs livländischer Selbständigkeit. Bd. 4. In: Archiv für die Geschichte Liv-, Est- und Curlands. Neue Folge. Bd. 4. Reval 1864, Nr. 72.

${ }^{159}$ AleXANDER BERgEgRÜN (Hg.). Eine livländische Relation über die Ereignisse in Livland aus der Zeit von 1599-1602. Mittheilungen aus der livländischen Geschichte. Bd XVII, 1. Riga 1900, S. 97-164, hier S. 121; S. 144, S. 146 (Augstroze); S. 151-153 u. c.

${ }^{160}$ RoBert Frost. Confessionalization and the Army in the Polish-Lithuanian Commonwealth 1550-1667. In: Konfessionalisierung in Ostmitteleuropa: Wirkungen des religiösen Wandels im 16. und 17. Jahrhundert in Staat, Gesellschaft und Kultur. Hg. von Joachim Bahlcke und Arno Strohmeyer. Stuttgart 1999, S. 139-159, hier S. 154; ZuTIS, Vidzeme kā poḷu un zviedru cinnas objekts, 99.-100. lpp.

${ }^{161}$ FriedRICH BiEnEMAN (Hg.). Zur Geschichte der livl. Ritter- und Landschaft 1600-1602. Briefe und Aktenstücke. In: Mitteilungen aus dem Gebiete der Geschichte Liv-, Est- und Kurlands. Bd. 17. Riga, Leipzig 1900, S. 463-600, hier S. 501, 502, 524, 560, 569.

\section{SUMMARY}

The article summarizes and explains the written sources of information about Livonian women's different estates of connection with hostilities in the context of regional history, provides the analysis of the aspects pertaining to military alliancebuilding and war funding. It focusses on testimonies of contemporaries about violence against women, on women as victims of war. Territorially and chronologically the study covers the contemporary Latvian and Estonian territory, starting with the beginning of the $13^{\text {th }}$ century and formation of Livonia to the split of territory as a result of the PolishSwedish War (1600-1629).

Firstly, the hierarchical society that overlays the role of women in the military sphere is analysed, focusing on certain individuals - Jersika ruler (Lat. - regina), that was captured in 1209 by crusaders led by bishop of Riga, as well as Danish king's wife and Estonian Margaret Sambiria, who as a regent organized and led troops in Denmark, and issued administrative acts in North Estonia, including those about the defense wall of Tallin. From the $14^{\text {th }}$ century to the mid-16 ${ }^{\text {th }}$ century, Livonia had a theocratic system of government. The article analyses the role of highest-ranking women during the Livonian war (1558-1582). The last Livonian Master Kettler was able to establish a dynasty and dukedom by marrying Mecklenburg Duchess Anna, while the Archbishop of Riga coadjutor Mecklenburg Duke Christoph in his hopes for Swedish princess' dowry and landlord status proved unsuccessful. Also, the administrator of Duke of SchleswigHolstein and several Livonian bishops Magnus (1540-1583) entered a political marriage with the Moscow Grand Duke's relative Maria Vladimirovna Staricka, however, it did not lead to far-reaching consequences. When viewing the connections with war in case of the upper-class Livonian females including knights/vassals, it can be concluded that throughout the period under consideration, they belonged to the "weaker sex" and personally did not participate in the wars, with the exception of the Danish Royal widow Margaret in the second half of the $13^{\text {th }}$ century, which highlighted the dynamic development of the status of queens at this time, when the status of widow in particular, was supported by the curia of Pope. Moreover, in the $16^{\text {th }}$ century during the collapse of 
Livonia, when the timely land domination was re-formed, an important role was acquired by dower (also imaginary territories) diplomatic and military alliances, that were formed as a result of matrimonial communication, but it was not the determining factor in transnational relations.

Looking at the testimony of women's active involvement in hostilities and military field, as well as information regarding Livonian women as victims of war violence, it must be noted that the majority of the historical testimonies are precursory stories with rather low reliability, which retell captivating, interesting occurrences or horrifying details, and reflects a standpoint of one side of the parties, with various arguments seeking to justify righteousness of narrator's or source's own actions, whilst portraying the enemy in the worst light.

This article summarizes the information about women's active involvement in several episodes of the war. It is noted that lower class women in rare cases turn against an opponent with rage resorting to very simple additional tools, as well as spying. It can be concluded that women did not use weapons, presumably, did not know how to use them and were not trained. Angry behaviour in state of affect or revenge were attributed to the lower class, but not to German women. Women were involved in organizing the defense with specific duties. City women, mostly widows, directly participated in enforcement of the defense walls, and their contribution during the war paid off the largest cities - Riga and Tallinn were the safest refuge in war turmoil of the late $16^{\text {th }}$ century and the early $17^{\text {th }}$ century.

In the section "War victims of violence" it was attempted to understand the numerous news in medieval and early modern period chronicles, which represent wars in Livonia in uniform formulas and women are allocated the role of a passive victim - mainly prisoner of war. The Chronicles in Livonia and in its neighbouring countries perpetuate the formula for successful foray: men are killed, women and children taken into captivity. The Crusaders from the West, newly baptized, heathens, as well as Orthodox believers all respected women and children's lives during the war, and also considered them a good commodity. Until the very beginning of the $17^{\text {th }}$ century, women a were part of war loot, used to receive a ransom or exploited as maids. Low-ranking and non-baptized war prisoners were bought and sold in manor houses, in the cities for hard daily work, although this type of servitude and also a massive transfer of prisoners of war in Livonia was limited at the beginning of the $15^{\text {th }}$ century.

Both Christians and pagans respected the lives of women and children in wartime. The foundation for sparing women's lives probably was not based solely in the Christian morality, but also in the conceptions and customary rights of the local people in the region, which included increased penalties for beatings, humiliation, and killing of women compared to the same offences against correspondingly ranking men. The principle is only partially reflected in Livonia legal codification and judicial practice; however, it is more typical of the Livonian neighbouring nations - Baltic (Lithuanian, Prussian) lands until the $16^{\text {th }}$ century, also known from north-western Russia's judicial practice.

Wars descriptions dating back to the mid-14 ${ }^{\text {th }}$ century, but especially those of the $16^{\text {th }}$ and $17^{\text {th }}$ centuries contain sexual violence descriptions against Livonian German women and the cruelty against infants and pregnant women, which referred to the beginning of the Estonian Saint George's Night Uprising in 1343, then later to the Grand Duke of Moscow and Allied Tatar troops, whereas in the early $17^{\text {th }}$ century - to Polish 
troops. It can be seen that written historical sources about the war are almost always very partisan and ideological. They are trying to cast the opponents in bad light, usually assigning to them acts of violence against those who are not capable of defending themselves. At the same time, perhaps, some of the events have been withheld. Written sources of military conflicts during the Crusades (the $13^{\text {th }}$ century - Estonian uprising of 1343) in Livonia were created only in German cultural space or under the shelter of Christian church, thus reflecting one-sided view from the conquerors' position. Also, the subsequent war review in Livonia was dominated by the German Order's point of view, that perpetrated pagan or Orthodox believers' opponents as the enemies of all the western Christian world, against whom Order stood like a defensive wall. If historic sources are available from two warring parties from the $15^{\text {th }}$ century to the $17^{\text {th }}$ century, it shows that both sides believed that their war was fair and worthy of Christians (German Order rhetoric and Pskov Chronicles of the $15^{\text {th }}$ to the $16^{\text {th }}$ centuries, Polish and Swedish Livonians at the beginning of the $17^{\text {th }}$ century). Livonian chroniclers and writers, perhaps, were characterized by a strong self-identification, quite automatically inserting themselves as protectors of Christianity characters, in Biblical scenes - events, localizing accordingly. At the beginning of a modern era, descriptions of violence became more frequent, and it can be discerned as belonging to the reality of its own time and changes in warfare, as well as in the parallels found in other Western European chronicles, the Old Testament and scenes in ancient legends. The appeal to mobilize battles and protect women from the enemy was described in horrific, vividly coloured violence.

Livonia as a border area between Catholic Europe, until the $15^{\text {th }}$ century pagan Lithuania and Orthodox Russia existed almost always. At the beginning of the modern period, its territory was the object of fights between the major regions. Women for five centuries were part of military conflict, where they mostly had the role of victims. Only few upper-class women affected military processes, and the means to do so included their family ties. 


\title{
Kopīgās tendences Latvijas Universitātes un Latvijas Republikas vēsturē starp pasaules kariem
}

\author{
Common Trends Shared By the University of Latvia and \\ the Republic of Latvia Between the World Wars
}

\author{
Raimonds Cerūzis, Dr. hist. \\ Latvijas Universitātes Vēstures un filozofijas fakultātes asociētais profesors \\ Aspazijas bulvāris 5, Rīga, LV-1050 \\ E-pasts: Raimonds.Ceruzis@lu.lv
}

Rakstā aplūkota Latvijas akadēmiskās elites iesaiste nacionālās augstskolas (vēlākās Latvijas Universitātes) izveidē un attīstībā starp abiem pasaules kariem. Vēstures avoti liecina par ciešo kopsakaru starp augstskolas izveides un attīstības iezīmēm un kopīgo valsts vēsturi dažādās tās attīstības stadijās starpkaru periodā. Plašāk apskatīti tādi aspekti kā augstskolas nozīme jaunās valsts ideolog̣ijā, starpnacionālās attiecības, saimnieciski finansiālie aspekti, tostarp darbinieku darba apstākḷi un atalgojums, kā arī mācībspēku iesaiste politiskajās aktivitātēs gan parlamentārisma, gan autoritārisma posmā. Visi šie aspekti atspoguḷo atbilstošas tendences valstī kopumā. Īpaši izcelta atsevišḳu personību loma, jo augstskolas mācībspēki Latvijas valsts tapšanas laikā un autoritārisma periodā uzskatāmi par viedokḷu līderiem.

Atslēgvārdi: Rīgas Politehniskais institūts, Latvijas Augstskola, Latvijas Universitāte, starpnacionālās attiecības, vācbaltieši, politika, ideoloǵija, izglītība, pētniecība, studijas.

The article reflects on involvement of the Latvian academic elite in the establishment and development of the University of Latvia between the two world wars. Historical sources show a close connection between the features of the establishment and development of the university and the common history of the country at various stages of its development in the interwar period. The aspects such as the role of higher education in the ideology of the new state, interethnic relations, economic and financial aspects, including their wages and working conditions, and the involvement of academics in political activities during both the parliamentary and authoritarian stages are discussed in greater detail. All these aspects reflect the corresponding trends in the country. The role of individual personalities is especially highlighted, since the teaching staff of the university is considered to be the leader of opinion during the formation of the Latvian state and the period of authoritarianism. 
Keywords: Riga Polytechnical Institute, University of Latvia, international relations, interethnic relations, Baltic Germans, politics, ideology, education, research, study.

\section{Augstskolas un valsts attīstības sākumi}

Ideja par latviešu augstskolu dzima vēl pirms Latvijas Republikas proklamēšanas. Līdzīgi kā prasības pēc latviešu pašnoteikšanās, arī augstskolas vīziju latviešu inteliǵences aprindas aktīvi sāka apspriest pēc 1917. gada Februāra revolūcijas Krievijas impērijā. Šo ideju atbalstīja plašs spektrs latviešu politiķu - gan konservatīvāk orientētie, gan liberālās pilsoniskās aprindas, gan strādniecība un latviešu strēlnieki, kas simpatizēja sociāldemokrātiem un pat vēlākajiem lieliniekiem.

Valsts un pirmās augstskolas tapšanas gaita bija tiešām spraiga. Īsā laika posmā bija risinājušies daudzi un škietami haotiski notikumi, kas mainija Latvijas politiskās reālijas. Spilgti tas atainojās Rīgā esošās augstskolas piemērā - to par pamatu jaunas augstskolas izveidei izraudzijās visas varas. Proti, jau Pirmā pasaules kara pēdējās nedēḷās vācu okupācijas vara Rīgā uz Politehnikuma bāzes izveidoja Baltijas Tehnisko augstskolu (Baltische Technische Hochschule), tad Pētera Stučkas vadītā lielinieku padomju Latvijas valdība pārn̄ēma latviešu augstskolas ideju un ar 1919. gada 8. februāra dekrētu Politehnikuma vietā nodibināja Latvijas Augstskolu, savukārt Andrieva Niedras valdība pēc Rīgas atkarošanas no lieliniekiem 1919. gada 22. maijā atkal tajās pašās telpās atjaunoja vācu veidoto Tehnisko augstskolu, un visbeidzot sekoja Kārḷa Ulmaṇa Pagaidu valdības veidotās Latvijas Augstskolas atklāšana 28. septembrī. Neatkarības gados no šīs plejādes kā Latvijas Augstskolas (vēlākās
Latvijas Universitātes - LU) priekštece tika izslēgta lielinieku pasludinātā augstskola parasti to ignorēja kā īsi pastāvējušu anomāliju. Tās statusu, līdzīgi kā visus lielinieku sociālistiskos pārveidojumus, pamatoti uzskatīja par pretlikumīgu, tādu, kas grauj tiesiskumu un tradīcijas. ${ }^{1}$

Augstskola bija viens no svarīgākajiem jaunās valsts kultūras, ideologijas un noteikti arī politikas izaicinājumiem. Pat nosaukuma meklējumi - vai mācību iestāde saucama par augstskolu vai universitāti - bija liels ideoloǵisks izaicinājums. Vēl ìsi pirms jaunā nacionālā augstskola vēra durvis studentiem, tās izveides komisijas vadītājs filozofs Pauls Dāle 1919. gada 12. septembra sēdē ierosināja to saukt par Latvijas Universitāti. Tomēr pret šādu tagad pašsaprotamu un ierastu nosaukumu izveidojās asa opozīcija, redzamākie tās pārstāvji bija agronoms un nākamais Lauksaimniecības fakultātes dekāns Jānis Bergs un teologs, vēlākais Filologijas un filozofijas fakultātes dekāns Kārlis Kundziņš. Viṇi uzskatīja, ka mācību iestādes nosaukums jāveido pēc iespējas latviskāks, proti, jāsaglabā apzīmējums "augstskola" un jāizvairās no internacionālā vārda "universitāte". Diskusija noslēdzās ar to, ka nolēma jautājumu nodot presei, lai ar tās palīdzību nosaukuma apspriešanā iesaistītu sabiedrību. ${ }^{2}$ Nekāda publiska diskusija gan nesekoja, tā vietā komisijas vairākums vienojās par nosaukumu Latvijas Augstskola. ${ }^{3}$ Bija vajadzīgi vēl trīs gadi, lai akadēmiskā elite atbrīvotos no aizspriedumiem un izškirtos par nosaukumu Latvijas Universitāte, kas saglabājies līdz mūsdienām. 1923. gada 28. martā Latvijas Republikas Saeima apstiprināja augstskolas Satversmi ar jauno nosaukumu. Ar vārdu kombināciju "Latvijas Universitāte" valsts netieši monopolizēja visu augstāko izglītību, neatstājot vietas citām universitāšu tipa augstskolām. Te jāatceras, ka Eiropā vispārpieņemtā prakse bija universitātes saukt pilsētu, nevis valstu 
vārdos. Tālaika Latvijas valstsvīru un akadēmiskās elites skatījumā bija būtiski uzsvērt, ka šì ir jaunās valsts universitāte un, ja radīsies citas, tās būs pakārtotas. Vēlāk LU akadēmiski zinātniskais pārākums izpaudās attieksmē pret jaunajām augstākās izglītības iestādēm, vispirms - Jelgavas Lauksaimniecības akadēmiju, bet jo īpaši cittautiešu veidotajām privātajām augstskolām, piemēram, Rīgas Herdera institūtu un Krievu universitātes zinātṇu institūtu. ${ }^{4}$

Augstskolas izveides tiesiskais pamats bija Pagaidu valdības 1919. gada 2. augusta lēmums par bijušā Rīgas Politehniskā institūta reorganizācijas komisijas izveidi, kas vēlāk pārtapa jaunās nacionālās augstskolas organizācijas komisijā. Sākotnēji process bija pilnīgā Politehnikuma mācībspēku kontrolē. Darba valoda komisijā bija krievu, jo kopš totālās rusifikācijas Krievijas impērijas augstskolās šì bija valoda, kurā saprasties spēja visi. Protokolus rakstīja gan krieviski, gan latviski, privātas sarunas sākotnēji bieži notika vāciski. Komisija sastāvēja no latviešiem un vāciešiem. Latvieši bija k̦īmiķis Pauls Valdens, agronoms Paulis Lejiňš, mašīnbūves inženieris Kārlis Rezevskis un ekonomists Frīdrihs Brēdermanis, kurš pildīja komisijas sekretāra atbildīgos pienākumus, bet vācieši - k̦īmiḳis Voldemārs Fišers (Woldemar Fischer), arhitekts Vilhelms fon Strīks (Wilhelm von Stryk), mehānikas inženieris Pauls fon Denfers (Paul Denffer), ārsts un anatoms Alfreds Zommers (Alfred Sommer), biologs Teodors (Fjodors) fon Buholcs (Theodor Bucholtz), vēsturnieks un geogrāfs Alfreds fon Hedenštrēms (Alfred von Hedenström) un būvinženieris Edgars Jakobijs (Edgar Jakoby). ${ }^{5}$ Kā redzams, stipri jūtams Politehnikuma mantojums - vairākumā bija eksakto zinātṇu pārstāvji, gara zinātṇu pārstāvjus no Tērbatas Universitātes tikpat kā nejuta.

Svarīgi zināt, ka pat latviskas izcelsmes komisijas dalībnieki bija konservatīvi un cieši ieauguši vāciskajā akadēmiskajā vidē, ippaši tas sakāms par P. Valdenu, kurš vadīja tikai pirmās komisijas sēdes (par viṇu sk. arī turpmāk). ${ }^{6}$ Pats P. Valdens atklāti politikā iesaistīties nevēlējās, bet to pašu nevar teikt par viņa kolēgiem. Starp komisijas dalībniekiem bija pavisam nesenajos vācu laikos politiski aktīvas personas. Tā, piemēram, agronomu P. Lejiṇu, vēlāko LU Lauksaimniecības fakultātes dekānu, ar vācu okupācijas varu saistīja viṇa vecākais brālis, pazīstamais ārsts Kārlis Morics Lejiņš. 1917. gada nogalē viņš bija iesaistījies vācu organizētās tautas pārstāvniecības darbā, kuras mērkiis bija izveidot Zemes padomi, kas vēlāk apstiprinātu vāciešu, latviešu un igaunu kopīgu "Baltijas valsts” projektu. Šo Vācijas un vācbaltiešu aristokrātijas politisko iniciatīvu vadīja vācbaltiešu izglītotais sabiedrības virsslānis. Respektablākie pārstāvji nāca no Tērbatas Universitātes un Rīgas Politehnikuma akadēmiskajām aprindām - studentu korporācijām. To vidū īpaši izcēlās korporācija Livonia, kuras biedri Ādolfs Pilars fon Pilhaus (Adolf Konstantin Jakob Pilar von Pilchau) un Heinrihs fon Strīks (Heinrich Eduard Karl von Stryk) Pirmā pasaules kara izskaņā bija nominēti par šīs valsts pagaidu valdības redzamākajiem pārstāvjiem. ${ }^{7}$ Vācu aktivitātēs bija līdzdarbojies arī ekonomists un vēlākais teologs F. Brēdermanis. Savu saistību ar izveidoto Zemes padomi viņš Latvijas proklamēšanas dienā tūlīt pat steidza presē apstrīdēt, kaut gan nenoliedza, ka tās pasākumos piedalījies. ${ }^{8}$ Bez šiem Politehnikuma reorganizācijas komisijas dalībniekiem topošās augstskolas saimē redzamu vietu ieņēma arī no jauktas latviešu un vācu vides nākušais nākamais LU Arhitektūras fakultātes dekāns, profesors un pazīstamais arhitekts Eižens Laube (Eugen Laube), kurš, tobrīd vēl būdams Politehnikuma docents, bija iesaistījies šo vācu plānu realizācijā un kḷuvis par Zemes padomes locekli. ${ }^{9}$ Starp citu, vēlāk F. Brēdermanis un E. Laube vēlreiz kopīgi izmēgénāja laimi 
politikā, startējot Satversmes sapulces vēlēšanās sarakstā no mācītāju un akadēmisko aprindu veidotās Kristīgās nacionālās partijas. ${ }^{10}$ Abu mēgóninājums atkārtoti iesaistīties politikā nevainagojās panākumiem.

Pēc Rīgas pakḷaušanas Pirmā pasaules kara laikā vācu okupācijas vara īpaši cerēja, ka vietējās akadēmiskās aprindas veicinās vācu varas nostiprināšanos. Ar tādu domu jau 1917. gada 8. decembrī Mazajā gildē uz plaši reklamētu sanāksmi bija pulcējušies apmēram 400 akadēmisko aprindu delegāti, lielākoties Rīgas Politehnikuma, bet arī Tērbatas Universitātes pasniedzēji, beidzēji un studenti, lai lūgtu Vācijas valdību uz mūžìgiem laikiem Rīgu un visu Baltiju iekḷaut Vācijas impērijas sastāvā. ${ }^{11}$ Akadēmiskā elite Pirmā pasaules kara gados sevi bija publiski pozicionējusi kā Vācijai lojālu un vācu plānus atbalstošu. Tagad politiskā situācija bija mainījusies, bija jāpielāgojas jaunajai realitātei, dažiem to izdarìt bija viegli, citiem grūti vai pat neiespējami, jo nebija pieņemama K. Ulmaņa Pagaidu valdības politiskā platforma. Pirms Latvijas proklamēšanas piedzīvotās politiskās neveiklības akadēmiskā elite tomēr turpmāk centās aizmirst un publiski vairs necilāt. Tā noteikti bija augstu vērtējama akadēmiski izglìtotas un tolerantas sabiedrības iezīme.

Latvijas Augstskolas izveide jau 1919. gada augusta otrajā pusē nonāca latviešu vairākuma rokās. Konservatīvo vāciešu īpatsvars reorganizācijas komisijā mazinājās. 1919. gada septembrī tajā līdzdarbojās virkne jaunpienācēju, to starpā turpmākajos gados pazīstamie Universitātes mācībspēki inženieris Pēteris Nomals, arhitekti E. Laube un Ernests Štālbergs, k̦īmiķis Mārtinšs Prīmanis, teologs K. Kundziņš u. c. ${ }^{12}$ Daudzi bija politiski aktīvi, viņus iedvesmoja iesaiste jaunās nacionālās augstskolas izveidē. Augstskolas tapšanas apstākḷi gan vairāk rāda pārmantojamību, nevis jaunā radīšanu. Jaunais slēpās idejā par nacionālo augstskolu, kur gatavotu valstij noderīgus speciālistus un mācības notiktu latviski, bet tās praktiskais izpildījums balstījās uz veco augstākās izglītības tradīciju. Līdztekus akadēmiski zinātniskajam mantojumam izteikta pārmantojamība no Rīgas Politehnikuma laikiem bija vērojama administrācijā un lietvedībā. Te faktiski nenotika nekādas izmaiņas. Kad 28. septembrī Latvijas Augstskola oficiāli vēra durvis, joprojām ienācēju augstskolā sagaidīja tas pats impozantais, krāšņā uniformā tērptais šveicars, imperatora jātnieku pulka gvardes bijušais kavalērists Pēteris Miḳelsons, kurš te bija strādājis kopš 1900. gada un turpināja šo darbu līdz pat 1935. gadam. ${ }^{13}$

Augstskolas kanceleja jeb sekretariāts un tā personālsastāvs tāpat bija maz mainījies. Sekretariātu vadīja latvietis Aleksandrs Valdmanis, kurš Politehnikuma kancelejā bija sācis strādāt jau 1889. gadā ${ }^{14}$ (turpat strādāja arī viṇa sieva). Vinšs turpināja vadìt sekretariātu gan Pirmā pasaules kara laikā, gan P. Stučkas valdīšanas mēnešos 1919. gadā, ${ }^{15}$ gan Latvijas Republikas un okupācijas laikā, līdz pat emigrācijai uz Vāciju 1944. gadā, kad bija sasniedzis cienījamu 70 gadu vecumu. Apbrīnojamās amata uzticības dēḷ (A. Valdmanis burtiski esot dzīvojis augstskolā) viņš bija tik pieredzes bagāts administrācijas jautājumos, ka vinuu respektēja visas varas un vecākās paaudzes akadēmiskais personāls. Turklāt A. Valdmanis konsekventi norobežojās no politikas, tādēl represīvās varas vin̄ā nesaredzēja pretinieku. Universitātes vadība vēlāk ierosināja A. Valdmanim piešķirt Triju Zvaigžņu ordeni par LU administrēšanu kara apstākḷos 1919. gada rudenī, tomēr, iespējams, tieši A. Valdmaņa politiskā distancētība un vāciskais tēls bija cēlonis, kādēl viņš apbalvojumu tā arī nesaṇēma. ${ }^{16} \mathrm{~K}$. Ulmaṇa autoritārisma gados LU iekšienē gan bija jūtama zināma kurnēšana par rektorāta (sekretariāta) un iestādes "pelēkā kardināla” A. Valdmaṇa škiietamo vāciskumu, kurš 
gímenē ar sievu sarunājies vāciski un, nen,emot vērā labo atalgojumu, pilnīgi nemaz nav pievērsies iestādes reprezentācijai uz ārieni. Darbu augstskolā A. Valdmanis beidza tikai līdz ar vācu okupācijas karaspēka un civilās pārvaldes atkāpšanos no Rīgas 1944. gada oktobrī. ${ }^{17}$ Zīmīgi un pamācoši ir tas, ka sekretariāts pildīja visas (!) augstskolas administrācijas funkcijas. Studentu skaits LU salīdzinājumā ar Politehnikuma laikiem bija pieaudzis, bet sekretariāta darbinieku skaits pat samazinājies. Kā augstskolas vadībai daudzkārt ziņoja sekretariāta darbinieki, viṇi tikuši galā ar pienākumiem, tikai pateicoties ilggadējai pieredzei. Situācijas ilustrācijai 1930. gadā LU bija 8570 studentu, bet sekretariātā - tikai 14 darbinieki. Tiešām apbrīnojama darba organizētība, kas nav iedomājama mūsdienās. Toreiz LU sekretariāts veica visu darbu studentu lietās, kā arī LU Padomes, dekānu padomes, rektorāta un citās lietās. Protams, sekretariāts regulāri sūdzējās par pārslodzi un prasīja darbinieku skaitu palielināt vismaz par 3-4 darbiniekiem. ${ }^{18}$

Līdzịgi kā valstī kopumā tās pastāvēšanas pirmajos gados, arī augstskolas darbības priekšnoteikums bija finansējums. Akadēmiskajās aprindās vispārzināms bija Rīgas Politehniskā institūta saimnieciskās veiksmes stāsts. Pirms darbības apturēšanas institūtam bija nauda, obligācijas, vērtspapīri un citas vērtības 869262,50 rublıu apmērā. ${ }^{19}$ Savukārt visa kapitāla lielums, ieskaitot nekustamo īpašumu, bija 2571 058,29 rubḷi - visnotal iespaidīga summa. ${ }^{20}$ Sākotnēji bija cerības, ka līdzekl̦us izdosies atgūt un tas būs "starta kapitāls" augstskolai. Drīz nacionālās augstskolas veidotāji bija spiesti piedzīvot smagu vilšanos, jo prāvie finanšu līdzekḷi kara un juku laikos bija zuduši. Daudzie stipendiju fondi un dāvinājumi bija jāpasludina par slēgtiem, jo līdzekḷi tajos nebija atgūstami. ${ }^{21}$ Tādēl 1919.-1920. gadā finanšu resursu trūkuma dēl personālā pat bija jūtama bezcerīga nolemtība. Pamatu izaugsmei saredzēja jaunatnes vēlmē studēt (proti, ar to saistītajās studiju maksās), kas kḷuva par raksturīgu tālaika sabiedrības iezīmi.

Visas varas, kas lielajā juku gadā 1919. gadā - valdīja Rīgā (lielinieki, vācieši utt.), bija plānojušas izsludināt studentu uzṇemšanu. Tai bija jānotiek septembrī. K. Ulmaņa Pagaidu valdība šo mērḳi turpināja īstenot. Pieprasījums pēc augstākās izglītības bija liels, prasība par latviešu inteliǵences vairošanu bija pašsaprotama, un valdīja pārliecība, ka tagad augstskolas durvis visiem nacionālajiem censoniem būs plaši atvērtas. Laika organizācijai bija pavisam maz, turklāt neviens nebija pilnīgi pārliecināts par militārpolitisko stabilitāti un valsts izredzēm - turpinājās brīvības cīṇas. Vispirms bija jāizlemj par kritērijiem studētgribētājiem. Kopumā saglabājās daudz iezīmju, kas piemita Krievijas impērijas laika kārtībai. Pirmais augstskolas rektors Ernests Felsbergs cara laika augstākās izglītības mantojuma iznīdēšanu studiju procesa organizēšanā pat pasludināja par vienu no svarīgākajiem darbības uzdevumiem. Uz Krievijas parauga balstītais obligāto priekšmetu lielais skaits, nepieciešamība pelnīt naudu studiju maksai, savā jomā vienīgā topošā speciālista atkarība no mazāk zinošiem profesoriem bija impērijas mantojums, ko viṇš vēlējās aizstāt ar Rietumeiropas liberālo augstākās izglītības pieredzi. ${ }^{22}$ Šādu uzdevumu varēja īstenot tikai ar atbilstošu akadēmisko personālu, bet tieši mācībspēku trūkums bija viena no galvenajām problēmām. Pēc lielinieku padzī̌anas no Rīgas 1919. gada vasarā augstskolas administrācijas pārstāvji konstatēja, ka par pasniedzējiem var noalgot tikai 14 štata pasniedzējus. Tie bija inženierisǵeologs Alvils Buholcs (Alwill Buchholtz), agronoms Vilhelms Burzians (Wilhelm Bursian), inženieris Oskars Hābermanis (Oskar Habermann), biologs Ernsts Hekels (Ernst Häckel), aizvēsturnieks un etnologs 
Fricis Henšels (Fritz Haensell), vēsturnieks un ġeogrāfs A. fon Hedenštrēms, inženieris Karls Heincs (Karl Heintz), arhitekts E. Laube, filologs Oskars Māzings jeb Maziņš (Oscar Masing), ${ }^{23}$ jurists Karls Šillings (Carl Schilling), statistiķis Burhards fon Šrenks (Burchard von Schrenck), filologs Alberts Fogts (Albert Vogt), arhitekts Eduards Veiss (Eduard Weiß), ${ }^{24}$ filologs Rūdolfs Cimmermanis (Rudolf Zimmermann), ${ }^{25}$ pieci ārštatnieki - kīmikis Maksimiliāns fon Glāzenaps (Maximilian von Glasenapp), veterinārmedikis Kārlis Kangro (Carl Kangro), valsts zinību speciālists Vilhelms Klumbergs (Wilhelm Klumberg), ${ }^{26}$ inženieris Georgs Nolteins (Georg Noltein), inženieris Voldemārs Vencelidess (Woldemar Wencelides) ${ }^{27}$ un seši asistenti. ${ }^{28}$ Protams, tas bija pieticīgs akadēmiskā personāla štats, turklāt absolūta vācu dominante, tomēr tieši šie cilvēki pelnījuši atzinību, jo vairums no viniiem kḷuva par pirmajiem Latvijas Augstskolas akadēmiskā personāla pārstāvjiem.

Svarīgs uzdevums bija atgūt pasaulē izklīdušos Latvijai piederīgos mācībspēkus un noteikt prasības akadēmiskajiem amatiem. Īpaši tas attiecās uz latviešiem. Prasības pasniedzēja amatam bieži bija visai pieticīgas, tas skaidrojams ar akadēmiskā personāla katastrofālo trūkumu. ${ }^{29}$ Sākums bija grūts un haotisks, bet jau 1921. gadā bija nokomplektēts mācībspēku pamatsastāvs - strādāja 48 profesori, 94 docenti, devin̄i privātdocenti, 19 lektori, 42 asistenti, bija izveidota un darbu sākusi centrālā bibliotēka. ${ }^{30}$ Turpmāk akadēmiskā personāla skaits turpināja augt, tā, piemēram, 1933. gadā jau bija 94 profesori un 160 asistenti. ${ }^{31}$

Līdzịgi kā mūsdienās, aktuāls jautājums bija motivējoša atalgojuma izmaksa, lai valsts augstskolai piesaistītu trūkstošo akadēmisko personālu. 1919. gada 9. septembra sēdē augstskolas veidotāji nolēma, ka sākotnēji noteiktā profesoru alga jāpalielina no 900 rubḷiem mēnesī lìdz
1200 rubḷiem, jo mācībspēku ieskatā algas lielums nebija konkurētspējīgs. Te gan jāteic, ka arī 1200 rublu lielais atalgojums pēckara inflācijas apstākḷıs bija pieticīgs. Sākotnēji augsti un reāli neizpildāmi bija arī pasniedzēju slodzes jeb nodarbinātības kritēriji. Tā, piemēram, bija noteikts, ka pilnas algas saṇemšanai jānovada sešas stundas nedēḷā - lekcijas vai praktiskās nodarbības. Profesoriem noteica algu par sešām stundām nedēḷā līdz 1200 rubḷiem mēnesī un par katru virsstundu 50 rubḷus nedēlāa . Docentiem paredzēja maksāt $3 / 4$ no profesoru algas, savukārt rektoram pie pasniedzēja algas nolēma papildus maksāt 600 rubḷu mēnesī utt. ${ }^{32}$

Vairākums augstskolas veidotāju ñēma vērā valsts smago saimniecisko realitāti un priekšstatos par atalgojumu bija pieticīgi. Tā, piemēram, K. Kundziņš, J. Bergs un S. Paegle pat bija pārliecināti, ka augstskolai jānodrošina pasniedzēji tādā apmērā, lai papildu darbs citviet nebūtu jāstrādā. İpaši to attiecināja uz papildu darbu valsts sektorā. Tādēl, nolēma, ka valsts dienestā strādājošie var augstskolā saṇemt tikai pusi algas. ${ }^{33}$ Ievērojami mazākas bija augstskolas sekretariāta darbinieku algas - vinuu pārziņā pēc darba uzsākšanas nonāca kopējā lietvedība, administrācija, visi nepabeigtie ar Politehnikuma pārņemšanu saistītie jautājumi utt. Augstskolas sekretariāta vadītājs A. Valdmanis 1920. gada augustā saṇēma 225 rubḷus mēnesī, vēl algoja tikai mašīnnrakstītāju un kurjeru. ${ }^{34}$

Lai saprastu, kāds bija augstskolas algu salīdzinošais apmērs, labs palīgs ir tālaika pārtikas produktu cenas. 1920. gada vasarā Rīgā viena mārcina $(0,453 \mathrm{~kg})$ rupjmaizes brīvajā tirgū bez pārtikas kartītes maksāja ap 2,5 rubliiem, mārciṇa cūkas spek̦a vai kartupeḷu - ap 5-6 rubl̦iem, mārciṇa kviešu miltu - ap 12 rubliem, mārcina sviesta - ap 27-30 rubliiem, bet importprece cukurs - pat vairākas reizes dārgāk par sviestu utt. ${ }^{35}$ Vēl jānem vērā, ka tobrīd 
Latvijā bija uzbangojusi pēckara pārvērtību izsauktā inflācija, pārtikas cenas kopš 1919. gada nogales bija palielinājušās vismaz divreiz. Tādējādi augstskolas samaksa drīzāk uzskatāma nevis par atalgojumu, bet gan darbu "par vēdera tiesu". Cenas laukos bija zemākas, bet rīdziniekiem tas neko nenozīmēja, jo tālāki braucieni bija retums. Droši var teikt, ka lielā mērā augstskolas izveide balstījās uz tās veidotāju entuziasmu un pašuzupurēšanos, līdzīgi kā tas notika arī Latvijas valsts izveides darbā.

Lielais pasniedzejju darba stundu skaits nedēẹā un ar to saistītā atalgojuma apjoms tika asi kritizēts jau kopš 1919.1920. gada. Visasāk to kritizēja pasniedzēji ar Eiropas augstskolu pieredzi. Sevišḳi izcēlās no Vācijas atbraukušais pazīstamais latviešu tautsaimniecības profesors un vēlākais politikịis Kārlis Balodis, kurš 1919. gada 23. septembra sēdē uzsvēra, ka ārzemēs profesoram prasa tikai divas lekciju stundas un vienu semināra stundu nedēḷā, tādēḷ arī Latvijā stundu skaita minimums būtu ievērojami pazemināms. ${ }^{36}$
Ilustrācijai ieskats Filolog̣ijas un filozofijas fakultātes darbinieku noslodzē 1920. gadā, kas, piemēram, bija krietni mazāka nekā Mehānikas fakultātē, kur bija daudz praktisko darbu (apm. 16 stundas nedēlāa). ${ }^{37}$

Jau tā samilzušajai atalgojuma problēmai un finanšu līdzekḷu nepietiekamībai kopš 1919. gada otrās puses klāt nāca bijušo Politehnikuma pasniedzēju, darbinieku, atraitņu vai citu pēcteču prasības par pabalstu un pensiju izmaksu. Bieži augstskolas veidotāji saņēma emocionālus iesniegumus par postu un trūkumu, kādā dzīvojušas redzamu universitātes profesoru atraitnes vai citi pēcteči. Ĺoti aktīvi pieprasīt Politehnikuma kādreiz pieškirtās privātās pensijas sāka mantinieki, atraitnes un bērni no Vācijas. Visbiežāk tie bija vācbaltieši, kas bija devušies emigrācijā pēc lielajām politiskajām pārvērtībām. Latvijas Augstskolai kā saistību pārnēemējai jau tā smagajā kara un pēckara laika finanšu situācijā pensiju izmaksa uzlika smagu slogu. 1920. gada iesākumā augstskolas

Tabula

Pamatdarbā Latvijas Augstskolā strādājošo pasniedzēju darba apjoms nedēḷā (noslodze) Filoloǵijas un filozofijas fakultātē 1920. gada rudens semestrī ${ }^{38}$

\begin{tabular}{|c|c|c|c|}
\hline Amats, vārds, uzvārds & $\begin{array}{l}\text { Vadito } \\
\text { nodarbỉbu } \\
\text { valoda }\end{array}$ & $\begin{array}{l}\text { Lekciju un/vai semināru nosaukums, ilgums } \\
\text { stundās }\end{array}$ & $\begin{array}{l}\text { Kopā } \\
\text { stundas } \\
\text { nedēḷā }\end{array}$ \\
\hline Doc. Leonīds Arbuzovs & Krievu & $\begin{array}{l}\text { Viduslaiku vēsture (4 st.), Vēstures seminārs } \\
\text { (2 st.) }\end{array}$ & 6 \\
\hline $\begin{array}{l}\text { Prof. (ar Mg. grādu) } \\
\text { Ernests Felsbergs }\end{array}$ & Latviešu & $\begin{array}{l}\text { Mākslas vēsture (2 st.), Ievads klasiskajā } \\
\text { filologijijā ( } 2 \text { st.), Griekijas vēsture (2 st.), Griekiu } \\
\text { autori (2 st.) }\end{array}$ & 8 \\
\hline Doc. Arnolds Spekke & Latviešu & $\begin{array}{l}\text { Spāņu literatūras vēsture (2 st.), Ievads romāṇu } \\
\text { filoloğijā ( } 2 \text { st.), Vakareiropas literatūras vēsture } \\
\text { (2 st.). }\end{array}$ & 6 \\
\hline Doc. Pēteris Zālīte & Latviešu & $\begin{array}{l}\text { Filozofijas vēsture (3 st.), Filozofijas seminārs } \\
\text { (2 st.) }\end{array}$ & 5 \\
\hline Prof. Jānis Endzelīns & Latviešu & $\begin{array}{l}\text { Latviešu valoda ( } 3 \text { st.), Slāvu valodas } \\
\text { salīdzinošais kurss ( } 3 \text { st.), Ģermāṇu pirmvaloda } \\
\text { (2 st.) }\end{array}$ & 8 \\
\hline
\end{tabular}


vadība gan apṇēmās maksāt līdz šim pieškirtās pensijas pensionētajiem darbiniekiem un atraitnēm samazinātā apmērā, ${ }^{39}$ tomēr drīz noteica, ka pensiju izmaksu regulēs speciāls likums. ${ }^{40}$

Apmēram divu gadu laikā pēc Neatkarības kara beigām atalgojuma sistēmu augstskolā izdevās sakārtot un padarīt taisnīgu un saprotamu. Tā, piemēram, 1922. gada rudenī rektora atalgojums pielīdzināts ministra biedra atalgojumam, profesori pielīdzināti 1. ierēdṇu kategorijai, kurus iecel Ministru kabinets, docenti - 4. kategorijai, kurus iecel resora priekšnieks utt., dekāni san̄ēma $30 \%$ no profesora algas plus 10 rubḷus par katru fakultātes studentu, fakultātes sekretārs - 25\% no profesora algas plus 2,5 rublius par katru studentu utt. ${ }^{41}$ Šì sistēma, kur augstskolas akadēmiskais personāls tika pielīdzināts valsts ierēdņiem, lāava vēlāk piešķirt valsts garantēto vecuma pensiju tiem, kas augstskolā vai citā valsts ierēdnim līdzvērtīgā amatā bija nostrādājuši vismaz 20 gadus. Lìdz okupācijai valsts garantētās vecuma pensijas attiecās uz visai šauru Latvijas iedzīvotāju daḷu, tādēḷ šāda iedzīvotāju grupa bija privilegèta.

Nesamērīgi augstu noteiktās pasniedzēju slodžu prasības 20. gados LU pakāpeniski samazināja un atalgojumu palielināja. Tas bija cieši saistīts ar vispārējo ekonomiskās situācijas uzlabošanos. Augstskola sāka izskaust mācībspēku daudzus gadus piekopto paralēlo nodarbinātību. Universitātes Padome 1925. gada 4. februārī pieņēma lēmumu, ka štata vieta augstskolā nav savienojama ar citu štata vietu valsts vai privātā dienestā uz pilnu darba laiku. Ar augstskolas Padomes piekrišanu bija atl̦auta blakus nodarbošanās, ja tā nav valsts darbs un ir saistīta ar mācībspēka specialitāti un netraucē darbam Universitātē. ${ }^{42}$

LU pasniedzēju personīgās lietas arhīvā liecina, ka jau 20. gadu beigās un 30. gadu sākumā profesori tomēr saṇēma Latvijas apstākḷiem l, loti labu atalgojumu. Tā, piemēram, Arhitektūras fakultātes dekāns, profesors un plaši pazīstamais arhitekts E. Laube par 1928. gadu bija atalgots ar 10 461,74 latiem (mēnesī vidēji 871 Ls), bet par 1930. gadu saṇēma 9461,84 Ls (mēnesī vidēji 788 Ls). ${ }^{43}$ Šāds atalgojums l̦āva ne tikai pilnvērtīgi pārtikt, bet arī iegādāties tālaika luksuspreces (gleznas, vērtslietas, radioaparātus, pat automobilus). Tā kā atalgojums bija saistîts arī ar valstī noteiktām valsts amatpersonu algu kategorijām, mācībspēki saṇēma līdzīgu atalgojumu, tas nemēdza atškirirties atseviškāa fakultātēs, un to nekādā veidā neietekmēja pasniedzēja tautība vai pavalstniecība. Tā, piemēram, Vācijas pavalstnieks, vācietis un LU ilggadējs teologijas profesors Imanuels Bencingers (Immanuel Benzinger) san̄ēma algu pēc 1. amatu grupas, kas 1930. gadā bija kopā 10368 Ls (mēnesī vidēji 864 Ls). ${ }^{44}$ Savukārt vēstures profesors vācbaltietis Leonīds Arbuzovs (Leonid Hans Nikolaus Arbusow) 1930. gadā saṇēma 8578,56 Ls (mēnesī vidēji 714 Ls). ${ }^{45}$ Turklāt jāatzīmē, L. Arbuzovs nebija pārlieku centīgs lektors, lekcijas 20. gadu nogalē joprojām lasīja krieviski, semestrī mēdza noturēt tikai vienu vai maksimāli divus nodarbību kursus un atseviškos gados kā zinātnisko sasniegumu norādīja tikai mazus šķirkḷus leksikonos vai dažas lapas apkopojošās grāmatās, kas izdotas ārpus Latvijas, toties devās zinātniskos komandējumos un savāca Latvijas vēsturei noderīgu materiālu Vatikāna arhīvā. ${ }^{46}$ Pasniedzēju atalgojums parasti spēja pilnībā nodrošināt viṇu gimenes. Profesoru atalgojums mēnesī bija pat 6-8 reizes lielāks nekā parastam rūpnīcas strādniekam. Profesoru un arī docentu sievas tādēḷ varēja nestrādāt algotu darbu - tā bija visai plaša parādība 30. gados. Solīdais atalgojums bija apliecinājums, ka LU augstu novērtē katru mācībspēku un viṇa sniegumu pat tajos gadījumos, kad mācībspēks vadīja tikai vienu lekciju kursu semestrī. 
Arī paši pasniedzēji bija lojāli savai darbavietai, nemēdza to pamest un strādāja l̦oti godprātīgi.

Liels saimniecisks ieguvums LU bija arhitekta un uzn̄ēmēja Kristapa Morberga pēcnāves novēlējums 1928. gadā. K. Morbergs novēlēja Universitātei astonuus namīpašumus Rīgas centrā un Jūrmalā, kā arī finanšu resursus. Latvijas apstākḷiem milzīgā dāvinājuma pārṇemšana un apsaimniekošana lika LU apgūt jaunas finansiālas un saimnieciskas ieman,as, kādas agrāk tai nebija vajadzīgas. Filantropa dāvināto īpašumu pārṇemšanā aktīvi iesaistījās viṇa atraitne vāciete Auguste Morberga, dzimusi Hartmane. Savukārt tūlīt pēc dāvinājuma saņemšanas uzradās vairāki K. Morberga radinieki un ǵimenes kalpotāji, kas lūdza ikmēneša pensijas no K. Morberga dāvinājuma (fonda). ${ }^{47}$

Saskaṇā ar mecenāta novēlējumu LU rīcībā nonāca arī prestižais viesnīcas "Roma" nams (saukta arī Hotel de Rome, Otrā pasaules kara laikā nams nodega, tagad tā vietā ir viesnīca "Rìga"). Tas uzskatāms par nozīmīgāko novēlējuma sastāvdaḷ. LU nolēma to iznomāt. 1930.-1931. gada mijā LU rīkoja sacensību (konkursu) par "Romas" viesnīcas un restorāna nomu. Vienlaicīgi ar nomnieka izvēli LU uzsāka arī vērienīgu viesnīcas pārbūvi. Būvdarbu kontroli uzṇēmās arhitekts, ilggadējais Arhitektūras fakultātes dekāns profesors E. Laube. ${ }^{48}$ Viesnīcas pārbūve sakrita ar vispasaules ekonomiskās depresijas periodu, tādēḷ projekta īstenošana ieilga, uz brīdi kḷuva pat bezcerīga. Krīzes iespaidā projekta finansēšanai nevarēja piekḷūt lielā filantropa uzkrātajam kapitālam. Kapitāls glabājās dažādās bankās, un visām bija radušās finanšu grūtības, tostarp sabrukumu piedzīvoja "Unionbanka" un dažādas savstarpējās kreditēšanas iestādes, kur mecenāts kādreiz bija ieguldījis naudu. Tādējādi apdraudēta bija visa K. Morberga novēlējuma finanšu līdzekḷu daḷa. Rīgas vācu prese, kas bija īpaši ieinteresēta viesnīcas jautājumā (viesnīcas un restorāni bija vācisks bizness, tāpēc arī "Romas" nomnieki Jirgensoni, būdami latvieši, saglabāja vācisku uzvārda transkripciju, lai turpinātu vēl pirms Pirmā pasaules kara popularitāti iemantojušā uzṇēmuma zīmola slavu), kritizēja LU par to, ka tā savu kapitālu nav glabājusi drošākā vietā, piemēram, Latvijas Bankā, ${ }^{49}$ bet augstskola attaisnojās, ka pats novēlētājs naudu ieguldījis šādos finanšu institūtos. ${ }^{50}$

Viesnīcas atklāšana pēc pārbūves 1932. gada 9. septembrī kḷuva par svarīgāko notikumu augstskolas dzīvē 1932. gadā un droši vien par nozīmīgāko saimniecisko notikumu visā tās pastāvēšanas vēsturē. Tās atklāšanu vadīja LU rektors Mārtiņš Bīmanis, piedalījās Valsts prezidents Alberts Kviesis, Ministru prezidents Margers Skujenieks, valdības ministri, ārvalstu diplomāti un citi sabiedrībā redzami l̦audis. Šī neapšaubāmi tobrīd bija lielākā, modernākā un prestižākā viesnīca valstī, līdz ar to tās atklāšana bija ievērojams notikums visas valsts dzīvē. Modernizācija un pārbūve skāra visas nama telpas, îpaši nozīmīga bija laikmetam atbilstošu vannas istabu izbūve viesnīcas 67 numuriņos, kā arī pirmā stāva restorāna Otto Schwarz un slavenā pagrabstāva restorāna-kroga "Romas pagrabs" (Romkeller) pārbūve. Viesnīcas numuriņu mēbeles un interjera priekšmeti gan vēl bija saglabājušies no iepriekšējiem laikiem un kādam varēja šḳist nolietoti vai bezgaumīgi. Liela nozìme "Romas" viesnīcas un restorānu spožajā slavā pirms un pēc renovācijas bija ši ğimenes uzṇēmuma ilggadējai valdes priekšsēdei Dorei Jirgensonei, kura, kā viesnīcas atklāšanas brīdī rakstỉja Rīgas vācu prese, bija lieluzņēmuma "smadzenes" un vienlaicīgi gastronomiski skolotā "dvēsele". ${ }^{51}$ Latviešu preses izdevumi savukārt cerīgi piebilda, ka restorāna saimnieki solījuši cenas turēt "piemērotas krīzes laikam". ${ }^{52}$ Jau pēc dažiem gadiem par viesnīcu teica, ka tā esot 
viena no labākajām Eiropā, līdzīgi arī tās restorāni, kas izceḷoties ar priekšzīmīgiem ēdieniem, grezno arhitektūru un interjeru franču karal̦a Ludviga XVI stilā. ${ }^{53}$ Tik tiešām, gan viesnīca, gan tās restorāni kḷuva par vietu, kur regulāri pulcējās valdības un dažādu organizāciju pārstāvji, notika diplomātiskas sarunas un vienošanās par līgumiem. Reizēm pat škita, ka "Romas" telpas monopolizējušas šo jomu, un, protams, LU varēja patiesi lepoties ar veiksmīgo saimniecisko darbību. Bija skaidri redzams, ka ienākumi par "Romas" viesnīcas apsaimniekošanu ḷauj vēl vairāk uzlabot atalgojumu Universitātē.

Svarīgs darījums LU notika 1940. gadā, līdzīgi kā viesnīcas "Roma” gadījumā, arī tam bija tālejoša nozīme augstskolas finanšu situācijas uzlabošanā. LU un K. Morberga fonds nolēma no Latvijas Kredītbankas iegādāties vācbaltiešu izceḷotāju atstāto viesnīcu Metropol (arī "Metropole", tagad viesnīca Astor), tādējādi kara apstākḷos ieguldot apdraudēto valūtu vērtīgā nekustamajā īpašumā. 1940. gada 18. martā LU un K. Morberga fonds nosūtīja attiecīgu pirkuma piedāvājumu Latvijas Kredītbankai, kuras pārzin̄ā bija nonākuši vācu īpašumi. 12. jūnijā, īsi pirms Latvijas okupācijas, Latvijas Kredītbankas direktors Andrejs Bērziņš deva savu piekrišanu darījumam. ${ }^{54}$ Ieñēmumus no viesnīcas apsaimniekošanas bija paredzēts izmaksāt mazturīgo un centīgo studentu stipendijām. ${ }^{55}$ Tāpat kā viesnīcu "Roma", arī Metropol LU vadītais K. Morberga novēlējuma fonds nodeva nomā A/S Ch. Jürgenson - Otto Schwarz, tikai šoreiz bez konkursa. ${ }^{56}$ Līdzšinējā veiksmīgā sadarbība un uzṇēmuma prestižs Eiropas mērogā padarīja alternatīvu meklēšanu par bezjēdzīgu.

Latvijas Augstskolas attīstība piedzīvoja līdzīgu saimniecisku izaugsmi, burtiski atspoguloja aktuālo valsts saimniecisko situāciju, ko diktēja gan pašmāju, gan starptautiskā situācija. Tādējādi augstskolas attīstībā labi vērojams gan pēckara saimnieciskās un finanšu krīzes iespaids, gan 20. gadu izaugsme, 30. gadu sākuma ekonomiskās krīzes iespaids un saimnieciska atkopšanās turpmākajos gados.

\section{Demokrātijas perioda sasniegumi un problēmas}

Tomēr daudz uzskatāmākas, pat sistemātiskas ir politiskās paralēles, kas sākas ar pašiem valsts pirmsākumiem. Baltijas Tehniskās augstskolas, vēlākie Latvijas Augstskolas studenti bija blakus latviešu politikiiem Tautas padomē, kad tā proklamēja Latvijas Republiku. Divas Rīgas latviešu studentu korporācijas "Selonija" un "Talavija" rūpējās par drošību Latvijas proklamēšanas laikā Rīgas Otrajā teātrī (tagad Nacionālais teātris). Savukārt nākamajā dienā, 1918. gada 19. novembrī, arhitektūras students, vēlākais brīvības cīnu dalībnieks, LU Filologijas un filozofijas fakultātes filozofijas absolvents ${ }^{57}$ un "Pērkonkrusta" organizācijas vadītājs, "Selonijas" biedrs Gustavs Celmiňš kopā ar savu korporācijas biedru Nikolaju Grundmani un citiem savas korporācijas biedriem pie tagadējās Latvijas Universitātes galvenās ēkas ieejas durvīm izkāra divus karogus, šūtus no teātrī izmantotā sarkanbaltsarkanā drapējuma. Tā bija pirmā reize, kad neatkarīgās valsts vēsturē pie kādas oficiālas iestādes vairākas dienas plīvoja Latvijas karogs. ${ }^{58}$ Dienu pēc Latvijas neatkarības pasludināšanas, vācu okupācijas karaspēkam vēl atrodoties Rīgā, G. Celmiņa vadībā no postamenta gāza arī vācu varas jaunizveidoto un latviešu nīsto vācu militārisma un spēka simbolu - no koka veidoto vācu "landšturma" (zemessardzes) karavīra monumentu, kas atradās laukumā pie tagadējās Rīgas apgabaltiesas. Studenti apsējuši virvi ap skulptūru, vilkuši to pa Rīgas ielām un kādā pagalmā sadedzinājuši, 
paturot koka šautenes galu kā trofeju, tādējādi Rīga un jaunā Latvija bija atbrīvojusies no okupācijas varas simbola, par kuru studentu aprindās klīdis ironisks skaitāmpantiņš: "Kas tika sists un nenosists, to tagad sargā landšturmists." ${ }^{59}$ Nedrīkst aizmirst arī par Rīgas studentu lielo atbalstu politiskām pārvērtībām 1918.-1920. gadā. Tā, piemēram, visas vācu studentu korporācijas jau 1918. gada novembra pirmajā pusē aktīvi iesaistījās vietējā karaspēka - zemessardzes (landesvēra) veidošanā un vēlāk Latvijas karaspēka sastāvā Neatkarības kara laikā (1918-1920) dedzīgi cīnījās ar lielinieku sarkano armiju. Līdzīgi arī latviešu studentu korporāciju veidotā Atsevišķā studentu rota bija viena no pirmajām Latvijas karaspēka vienībām un pašaizliedzīgi piedalījās cīṇās ar Latvijas pretiniekiem. Tās komandieris Artūrs Galindoms pēc LU Arhitektūras fakultātes beigšanas kḷuva pazīstams kā Baltijas valstīs pirmā modernā iepirkšanās centra - Armijas ekonomiskā veikala (tagad "Galerija Centrs") - un Latvijas Kara muzeja projektu autors.

Studenti un akadēmiskā vide tolaik bija intelektuālie līderi, kas pārējai sabiedrībai rādīja vajadzīgo politiskās attīstības virzienu. Nereti šis virziens ieņēma izteikti nacionālu nokrāsu un radīja domstarpības starp latvisko un vācisko. Tā bija raksturīga perioda iezīme, bet pēc brīvības cīnu beigām vairs nekad nenoveda pie bruṇotas sadursmes.

Politiskā attīstība savu zīmogu atstāja arī uz augstskolas vadību. Spilgts piemērs ir P. Valdens, kam nenoliedzami bija liela pieredze Rīgas Politehniskā institūta direktora amatā (1902-1906) un lieli nopelni kīmijā. Kara un juku gados pat bija grūti iedomāties citu augstskolas vadītāju vina vietā. Pat lielinieku režìms P. Valdenu 1919. gada 7. maijā iecēla par augstskolas vadītāju, un viņš paguva izpelnīties padomju preses uzslavas kā Latvijas Augstskolas "nopietnākais zinātnieks". ${ }^{60}$
Augstskolas vadītāja amatā viṇš palika arī vēlāk, kad A. Niedras Latvijas Pagaidu valdības provāciskie spēki 1919. gada 22. maijā lieliniekus bija padzinuši no Rīgas un atjaunoja vācu laiku Tehnisko augstskolu, bet 1919. gada 2. augustā K. Ulmaņa Pagaidu valdība viņu apstiprināja par Bijušā Rīgas Politehniskā institūta reorganizācijas komisijas vadītāju un par Latvijas Augstskolas faktisko pagaidu vadītāju, vēl vairāk - 4. augustā iecēla pat par Izglìtības ministrijas Zinātnes un augstskolas departamenta direktoru. ${ }^{61}$ 1919. gada 26. novembrī bijušā Rīgas Politehniskā institūta reorganizācijas komisijas (kopš 16. septembra - Latvijas Augstskolas organizācijas komisijas) priekšsēdētāja amatu no P. Valdena pārnēèma izglītības ministra Kārḷa Kasparsona ieceltais filozofs P. Dāle, kurš šo amatu pildīja līdz 1921. gada 1. jūlijam. ${ }^{62}$ Savukārt no Zinātnes un augstskolas departamenta direktora amata P. Valdenu valdība atbrīvoja tikai 1919. gada 29. decembrī, ${ }^{63}$ kaut gan faktiski visus Latvijā ieņemtos amatus viņš pārstāja pildìt jau 1919. gada 16. augustā, kad komandējuma aizsegā bija devies uz Vāciju pie sievas; uz Latvijas Augstskolas atvēršanu 28. septembrī viņš neieradās ${ }^{64}$ un drīz sāka strādāt Rostokas Universitātē.

Tā kā P. Valdens bija audzis un skolojies vāciskā vidē un ar to cieši saradis, pret savu, augstskolas un visas valsts latviskumu viņš bija vienaldzīgs. P. Valdena uzskati sakrita gan ar tradicionālo Baltijas vācu eliti, gan ar internacionāli noskaņotajiem latviešu lieliniekiem, kuri pret latvisku augstskolu izturējās skeptiski. Saskaņā ar laikabiedru liecībām viņš apšaubījis mazu nāciju kultūras pastāvēšanu un ironizējis par latviskas augstskolas iespēju, bieži pieminējis, ka kīmijā latviski rakstīt un lasīt nav iespējams. ${ }^{65}$ Zīmīgi arī, ka vinšs pārtrauca darbu jaunveidojamā augstskolā brīdī, kad Latvijas Republiku sāka apdraudēt Pāvela Bermonta-Avalova tā sauktā 
Rietumu brīvprātīgo armija (Zapadnaja dobrovol'cheska armija, Die Westrussische Befreiungsarmee) Kurzemē. Tajā laikā viens no pirmajiem augstskolas organizācijas projekta iniciatoriem, jau pieminētais teologs K. Kundziņš, pēc Bermonta uzbrukuma sastādīja paziņojumu ārvalstīm, kurā nosodīja šādu agresiju un lūdza atbalstu no pasaules zinātniskām aprindām. Šo uzsaukumu parakstīja gan Augstskolas organizācijas komisijas dalībnieki, gan citi mācībspēki, tostarp arī vācbaltieši, bet P. Valdena vārda starp parakstītājiem nebija. ${ }^{66}$ Tādā veidā P. Valdens netieši demonstrēja savu attieksmi pret notikumiem Latvijā. Izglītības ministrs K. Kasparsons rīkojumu par P. Valdena aizvietošanu ar P. Dāli izdeva 1919. gada 26. novembrī, t. i., nākamajā dienā pēc Pagaidu valdības apspriestās un Vācijai nosūtītās notas par karastāvokli abu valstu starpā. ${ }^{67}$

Pēc Otrā pasaules kara sarakstītajās atmin̄ās P. Valdens sevi pieskaitīja pie "bēgliem”, kas devušies uz Vāciju 1919. gada vasarā, lai glābtos no revolucionārajiem komunistiem. ${ }^{68}$ Tas nav patiesi, jo lielinieki tobrīd jau vairākus mēnešus atkāpās, bija piedzīvojuši sakāvi, un Latvijas teritorijas pilnīga atbrīvošana bija tuvāko nedēḷu jautājums, arī lielinieku popularitāte sabiedrībā jau bija strauji kritusi, turklāt lielinieki taču bija izraudzijjušies P. Valdenu arī par pašu veidotās augstskolas vadītāju. Savukārt 1924. gadā, aprakstot Latvijas Augstskolas dibināšanu, P. Dāle diplomātiski izvairīgi rakstīja, ka P. Valdens esot aizbraucis "zinātniskā komandējumā" uz Vāciju un "dažādu apstākḷ dēḷ neatgriezās vairs atpakal̦". ${ }^{69}$ Šis diplomātiskais formulējums iegājies arī Latvijas zinātnes vēstures pētījumos. $^{70}$ Situāciju skaidrāku nepadara arī tolaik Latvijas Preses biroja izplatītā ziņa, ka P. Valdens aizbraucis 1919. gada 16. augustā Izglītības ministrijas uzdevumā, proti, kā departamenta direktors (ierēdnis), lai “ārzemēs organizētu mācību lìdzekḷu savākšanu Latvijas Augstskolai”. ${ }^{71}$ Protams, tik sarežgìitos kara, juku un atbildīgu administratīvu uzdevumu apstākḷos "zinātnisks komandējums" vai "grāmatu vākšana” izklausās neticami. Visdrīzāk te ir runa par neapmierinātību ar P. Valdena attieksmi pret līdzšinējiem politiskajiem procesiem. Visai labā atmināa bija norises 1905. gada revolūcijas laikā. Tobrīd studenti vēlējās iesaistīties augstskolas pārvaldē, vinuus neapmierināja augstskolas vadības un daḷas pasniedzēju konservatīvisms, kā arī atbalsta trūkums revolucionārajai kustībai un iebildumi pret regulāru sanāksmju (politisko mītinuu) rīkošanu Politehnikuma telpās. ${ }^{72}$ 1905. gada janvāra pirmajā pusē studentu sanāksmes Politehnikuma telpās bija ikdienišḳa parādība. Direktora P. Valdena ierašanās uz kādu no nelegālajām sanāksmēm 1905. gada 14. janvārī studentus nemaz nenomierināja, tādēḷ lekciju lasī̌sana tika pārtraukta un institūta vadība neredzēja iespējas drīzumā atjaunot normālu mācību iestādes darbu. ${ }^{73}$ Vēlāk institūts atsāka darbu ierobežotā veidā, taču tikai uz neilgu laiku. Nemieru rezultātā augstskolu slēdza līdz 1906. gada augusta beigām.

Patiesībā revolūcija neizgaisa no akadēmiskās vides atminas visu starpkaru periodu - pārāk dramatiskas un spraigas bija šīs norises. Un, lai arī vairākums šī laika studentu bija dzimuši jau pēc revolūcijas, priekšteči mēdza krāšņi izstāstīt tālaika norises. Spilgts piemērs ir minētais Universitātes ilggadējais šveicars (durvju sargs un ne tikai) P. Miḳelsons. 1935. gadā viņš presei, piemēram, stāstīja, ka studenti uz augstskolas priekšniecību metuši pudeles ar smirdīgiem kịimiskiem šķidrumiem un Inženierzinātṇu fakultātē pat iesvieduši laboratorijā paštaisītu "bumbu". ${ }^{74}$ 1905. gada 28. oktobrī Latviešu Otrā teātra telpās (vēlāk - Jaunais Rīgas teātris) vispārējā studentu sanāksmē pulcējās ap 1000 studentu, vairākums pieprasīja atcelt 
no augstskolas direktora posteņa P. Valdenu kopā ar viņa palīgiem. ${ }^{75}$ Tã iespaidā jau tajā pašā dienā P. Valdens izvērstā iesniegumā lūdza augstskolas padomei atbrīvot vinuu no direktora amata, ${ }^{76}$ bet 1906 . gada 1. janvārī devās uz ārzemēm, pamatojot to ar ārstēšanos, bet patiesībā bēga no atriebības. ${ }^{77}$ Brīdī, kad veidojās Latvijas Augstskola, P. Valdens to atminējās kā nepamatotu studentu naida izpausmi, pēc gadiem gan atzina, ka revolucionāros musinātājus no augstskolas tomēr bija padzinis un tādēḷ sekojusi neapmierinātība. ${ }^{78}$ Patiesībā studentu atskaitīšana tolaik bija masveida parādība. Kopš 1902. gada augstskola l̦oti rūpīgi kontrolēja studentus, par politiski aktīvajiem vāca informāciju, ziṇoja drošības iestādēm utt. Dokumentācija bija P. Valdena akceptēta un parakstīta. ${ }^{79} \mathrm{Nav}$ brīnums, ka no studijām atskaitītajiem un viņu domubiedriem visu atlikušo mūžu, vēl ilgi starpkaru periodā, saglabājās naids pret augstskolas bijušo vadību un atsevišķiem mācībspēkiem.

Savukārt 1920. gada sākumā jaunāko "Valdena lietu" (toreiz tā to sāka saukt) izskatīja Latvijas Izglītības biedrības augstskolu sekcijā, kas atzina, ka pret P. Valdenu vērstie apvainojumi ir "netaktiski un neattaisnojami". ${ }^{80}$ Par to, ka P. Valdena aizbraukšana 1919. gadā tomēr bija politiski motivēta un "Valdena lietai" ir pamats, liecina asā vārdu apmaiņa avīzē "Latvijas Vēstnesis", kas izcēlās 1924. gadā. Šajā gadā saskan̄ā ar LU vadības aicinājumu P. Valdens ieradās Rīgā un Latvijas Universitātē nolasīja piecas vieslekcijas par moderno k̦īmiju. ${ }^{81}$ Polemika aizsākās ar to, ka 1919. gada notikumu aculiecinieks, latviskās augstskolas idejas aizstāvis, LU fizikas docents, vēlākais ilggadējais Matemātikas un dabaszinātṇu fakultātes dekāns Fricis Gulbis "Latvijas Vēstnesī” publicēja vienu un pēcāk atbildei otru rakstu, kuros pauda, ka P. Valdens apjūsmojis vācu karavīru ienākšanu Rīgā 1919. gada maijā un terora sākšanu pret latviešiem..$^{82}$ No Latvijas viņš 1919. gadā esot aizbraucis kopā ar naudu, kas viṇam uzticēta mācību materiālu iegādei, un san̄ēmis atalgojumu pat vēl pēc P. Bermonta sakāves, kaut gan tobrīd bija jau lūdzis Vācijas pavalstniecības pieškiršanu. "Valdens [...] aizbrauca apzinigi un ar nodomu [...] Latvijai un vinas augstskolai viňš nav ticējis [...]"83 Tā emocionāli rakstīja F. Gulbis; viṇa tuvs radinieks no mātes puses bija revolucionārs un viens no pirmajiem neatkarīgas Latvijas idejas aizstāvjiem Ernests Rolavs, kuru pēc bēgḷa gaitām vācbaltiešu muižnieki apcietināja, piekāva un nošāva 1907. gadā pie Grobinas. ${ }^{84}$

Pēc F. Gulbja rakstiem presē aizstāvēt P. Valdenu metās pazīstamais tautsaimniecības profesors un labs P. Valdena pazina no Vācijā pavadītā perioda - K. Balodis, kurš divos emocionālos rakstos apgalvoja, ka P. Valdens taču pat mācējis runāt latviski, bet uz Latvijas Augstskolas atvēršanu 1919. gada 28. septembrī neesot varējis no Vācijas ierasties slimības un līdzekḷu trūkuma dēl. ${ }^{85}$ Līdzīgi arī Latvijas pirmā ārlietu ministra Zigfrīda Annas Meierovica palīgs un labs K. Baloža draugs matemātiķis, praktizējošs diplomāts un pazīstamais žurnālists Henrijs Simsons noraidīja izskanējušos pārmetumus par P. Valdenam "trūkstošo nacionālismu" un cildināja viņa zinātniskos sasniegumus. ${ }^{86}$ Abu P. Valdena aizstāvju raksti gan jāuztver drīzāk kā viņu personīga simpātija un nekas vairāk, jo 1919. gadā viṇi nebija iesaistīti Latvijas Augstskolas izveidē un atradās ārzemēs (K. Balodis - Vācijā, bet H. Simsons - Lielbritānijā), tādēl par notikušo zināja maz. K. Balodis turpmāk iemantoja l,oti pretrunīgu slavu, jo mēdza dīvainā manierē paust visai juceklīgus uzskatus, bet H. Simsons vinuu pat varbūt pārspēja, par ko liecina vina pirmskara sarakstes paziņas Jāṇa Pliekšāna (Raiṇa) atstātās liecības par H. Simsona "nenormālību" un vēlākā ārstēšanās psihiatriskajā slimnīcā. ${ }^{87}$ 
P. Valdenam Latviju pametot un vāciskās elites ietekmei valstī sarūkot, 1919. gada izskaṇā iezīmējās konsekvence nacionālās augstskolas izveides virzienā. Vadību pārṇēmušais filozofs P. Dāle labāk apjauta humanitāro nozaru nepieciešamību jaunajā Latvijas valstī un jaunajai latviešu nācijai. Bez stipras humanitāras nozares nevarēja izveidot stabilu akadēmiski intelektuālu un patriotisku vidi gan augstskolā, gan valstī kopumā. Veidojot valsts augstskolu, īstenojās tas pats princips, kas valsts pārvaldē, - noteicošam bija jākḷūst demokrātiskajam vairākumam, proti, latviešiem. Latviešiem kā vairākumam bija nepieciešams uz valsts izglītību balstīts garīgo vērtību pamats. Brīdī, kad komisijas sastāvā sāka iezīmēties latviešu demokrātiskais vairākums, kḷuva skaidrs, ka Politehnikuma akadēmiskā struktūra būs krietni jāpaplašina humanitāro zinātṇu virzienā. Šajā jomā l,oti rosīgs bija tieši P. Dāle, kurš konsekventi iestājās par Filologijas un filozofijas fakultātes izveidi, kuras paspārnē varētu attīstìt tādas latviešiem nozīmīgas zinātṇu jomas kā vēsture, valodniecība, filozofija. ${ }^{88}$ Tāpat viņš aktīvi atbalstīja Teoloǵijas fakultātes izveidi. ${ }^{89}$ Arī šī joma bija ārkārtīgi svarīga un saistīta ar jaunās demokrātiskās valsts pamatprincipiem. Teoloǵijas fakultātes ietilpināšana augstskolā nozīmēja abu valsts lielāko kopienu - luterāṇu un katoḷu - zināmu savaldīšanu un tuvināšanu. Gan luterāṇu baznīca, gan katoḷi līdz tam brīdim bija atradušies vecās elites, tostarp muižniecības, kontrolē (muižnieku patronāts), turklāt arī šeit uzskatāmi iezīmējās vāciskā dominante. Abas kristīgās konfesijas pārstāvēja divas nosacìtas kultūrtelpas - luterāṇi bijušās Baltijas gubern,as, bet katoḷi Vitebskas guberṇu (Latgale) -, kuras ilgstoši bija savstarpēji noškirtas. Latvijas sabiedrība kopumā bija tradicionāli dievbijīga, tādēḷ akadēmiska kontrole pār reliğijas jomu bija svarīgs aspekts, lai stiprinātu politisku stabilitāti valstī. İpašs jautājums bija Latgales kulturālās autonomijas prasības, kuras uzturēja katoḷticīgās kopienas pārstāvji, redzamākie latgaliešu valodas un kultūras aizstāvji, politiķi un literāti Francis Trasuns un Francis Kemps. Tādēl Teolog̣ijas fakultātes izveidi varēja pieskaitīt pie pasākumiem Latgales separātisma novēršanai. Arī te atradās neapmierinātie. Visvairāk šādu fakultātes izveidi parlamentārās demokrātijas laikā kritizēja lielākais politiskais spēks - sociāldemokrāti. Vini pieprasīja reliǵijas pilnīgu izslēgšanu no valsts aprites, nesaredzēja tajā neko akadēmisku, tikai māṇticību, daudzkārt pieprasīja Teologijas fakultātes slēgšanu, tās likvidēšanu iekḷāva pat partijas 1930. gada programmā. ${ }^{90}$

LU akadēmiskā vide bija būtiska sastāvdaḷa starpkaru perioda Latvijas sabiedrības elitē, tādēḷ tai bija cieša saistība ar politiku, tikai par to mēdza visai maz runāt.

Parlamentārisma gados dạ̣a LU mācībspēku aktīvi iesaistījās lielajā politikā, bieži uznēmās izglītības ministra amatu. Par ministriem kḷuva filologijas profesors Juris Plāķis (no 1920. gada 12. jūnija līdz 1921. gada 26. aprīlim), vecākais ekonomikas docents Longīns Ausējs (ministrijas pārvaldnieks no 1921. gada 27. aprīḷa līdz 18. jūnijam), filolog̣ijas profesors Aleksandrs Dauge (no 1921. gada 19. jūnija līdz 1923. gada 26. janvārim), filologijas profesors Kārlis Straubergs (no 1924. gada 27. janvāra līdz 18. decembrim), filolog̣ijas profesors E. Felsbergs (no 1924. gada 19. decembra līdz 1925. gada 4. martam), kīmijas profesors Arvīds Kalniņš (no 1925. gada 5. marta lìdz 23. decembrim), inženierzinātṇu profesors Edmunds Ziemelis (no 1925. gada 24. decembra līdz 1926. gada 17. decembrim un no 1928. gada 2. decembra lìdz 1931. gada 4. decembrim), vēstures profesors Augusts Tentelis (no 1928. gada 23. janvāra līdz 1. decembrim). ${ }^{91}$ No 17 reizēm, kad biežo valdības krīžu dēḷ tika meklēti Izglītības 
ministrijas vadītāji, deviņas reizes tie tika atrasti LU mācībspēku aprindās. Kā redzams, lielākoties tie bija humanitāro nozaru pārstāvji, jo tieši vini tolaik vislabāk spēja formulēt nacionālās izglītības un zinātnes mērḳus un uzdevumus, citiem vārdiem - bija šīs jomas vadošie ideologi. Turklāt LU profesori bija visi trīs autoritārisma perioda izglītības ministri (teologíjas profesors - fakultātes dekāns Ludvigs Adamovičs, vēstures profesors - rektors A. Tentelis, kiīmijas profesors - dekāns, rektors Jūlijs Auškāps). Tādējādi nacionālās augstskolas autoritāte šajā laika posmā bija neapstrīdama izglītības politikas jomā, var pat teikt, ka autoritārisma perioda izglītības un zinātnes politika bija LU veidota. Daḷeji Alma Mater bija veidota pat visa autoritārisma ideolog̣ija Latvijā.

Latvijas Augstskolas un vēlākās LU pārstāvji l̦oti agri bija nonākuši varas pašā augstākajā līmenī, jo tie bija pieskaitāmi pie sākotnēji visai šaurā latviešu sabiedriski politiskā virsslān,a. Tā jau 1919. gada novembrī Augstskolas organizēšanas komiteja Tautas Padomes priekšsēdētāju Jāni Čaksti ievēlēja par jurisprudences profesoru. J. Čakste aktīvi līdzdarbojās augstskolas organizēšanā un lasīja lekcijas līdz 1922. gadam, kad Saeima vinuu izraudzījās Valsts prezidenta amatam. ${ }^{92}$ J. Čakste bija Demokrātiskā centra galvenā politiskā figūra. Tā bija partija, kurā apvienojās daudzi sabiedriski darbinieki. No šis partijas J. Čaksti 1920. gadā ievēlēja Satversmes sapulcē, kā arī 1. un 2. Saeimā. 1. Saeimā no šī paša saraksta ievēlēja toreizējo Latvijas Augstskolas rektoru E. Felsbergu, bet 3. un 4. Saeimā arī LU docentu biologu Kārli Kiršteinu..$^{93}$ Tomēr šis nebija vienīgais politiskais spēks, kas bija simpātisks akadēmiskajai elitei.

Vairāki LU mācībspēki pieslējās redzamā politiķa, jurista Arveda Berga Latviešu nacionālajai apvienībai, viṇa vadītais laikraksts "Latvis" bija asā opozīcijā spēcīgākajai Latvijas Sociāldemokrātiskajai strādnieku partijai un tās laikrakstam "Sociāldemokrāts". 1925. gada Rīgas domes vēlēšanu sarakstā no 90 šìs partijas kandidātiem desmitā daḷa bija prominenti LU docenti un profesori (L. Ausējs, J. Auškāps, Ernests Birkhans, Jānis Jankovskis, Arveds Leppiks, M. Prīmanis, K. Rezevskis, Vilis Vìtols, E. Zarinšs). Arī rektoram E. Felsbergam simpatizējuši A. Berga uzskati. ${ }^{94}$ No minētajiem ekonomikas docentam L. Ausējam izdevās kḷūt par 2. un 3. Saeimas deputātu.

Redzamu vietu politiķu vidū ieņēma pazīstamais tautsaimniecības un demogrāfijas profesors, pārtikas kartīšu sistēmas izgudrotājs K. Balodis. Viņš l,oti, varbūt pat vairāk nekā citi vina amata brāḷ no LU vēlējās iesaistīties politikā, īpaši viṇam rūpēja saimniecības attīstība. 1919. gadā pārbraucis Latvijā no Vācijas, viṇš iestājās Latvijas Sociāldemokrātiskajā strādnieku partijā, bet, nesaṇemdams atbalstu savām idejām, izveidoja pats savu mazpartiju Latvijas Darba savienību un tautas apvienību - un aktīvi turpināja paust kreisus ekonomiskus priekšstatus, tādēl iemantoja daudzus nelabvēḷus pilsoniskajās aprindās un arī LU akadēmiskajā vidē. ${ }^{95}$ Zināmas paralēles ar mūsdienām iezīmē šīs partijas devīze: "Mēs solām, jo zinām, ka spējam savus solijumus pildit!"96 1928. gada novembrī no šīs partijas K. Balodis bija ievēlēts par 3. Saeimas deputātu, bet pēc viña pēkšñās nāves šo amatu ieņēma kandidātu saraksta otrais numurs, vina draugs un svainis, bijušais "Mājas Viesa" un "Dienas Lapas" redaktors LU filozofijas profesors Pēteris Zālīte. ${ }^{97}$

No akadēmiskās vides nākušie politiķi bija visai atšḳirīgi no pārējiem deputātiem un ar savu mērenību un inteliǵenci bieži neiederējās skaḷajā, tirgum līdzīgajā Saeimas arēnā, kur daudzi tikai sāka apgūt demokrātijas pieredzi. Tāpat nevar teikt, ka no šiem politiķiem kāds būtu kḷuvis 
populārs sabiedrībā. Drīzāk sabiedrība saskatīja dažādas dīvainības, kas piemita politikā nonākušajiem profesoriem un docentiem un nekautrējās par tām pazoboties. Tā, piemēram, satīras žurnāls "Svari” LU rektoru E. Felsbergu, kurš 1924. gada rudenī bija izstājies no Demokrātiskā centra, divdomīgi sauca par "ekscentriki". ${ }^{98}$ Ipaši bieži prese mēdza pazoboties par jau pieminētajiem politiḳiem - profesoriem K. Balodi un P. Zālīti, kurus uztvēra kā nedalāmu politisku tandēmu, kas viens otru apstiprina un papildina. Tā, piemēram, "Svaros" lasām, ka deputāti "vismị̄āak lustējas ap prof. Balodi" - tikko profesors kāpj tribīnē, tā deputāti tūlin "pieñem valı̆gākas pozas un vinu sejām pārlido bezbēdīgs smaids - "Tūlin būs lustes!" vinu acis labsirdìgi saka". ${ }^{99} \mathrm{Kad}$ P. Zālīte deputāta amatā aizstāja savu mirušo svaini un kolēǵi K. Balodi, viņš kḷuva pat par sistemātisku zobgalību upuri. ${ }^{100}$

\section{Autoritārisma tendenču iespaidā}

Kopš autoritārisma nostiprināšanās 1934. gada maijā akadēmisko brīvību un demokrātiju uzskatos LU pakāpeniski sāka aizstāt autoritārs klišejisms, aizkulišu noslēpumainība, cenzūra un improvizēta pašdisciplīna. Iepriekš avīzēs un sanāksmēs plaši apspriestās LU problēmas vai personību konflikti vairs nepārtapa rakstītā vārda formā. Kulmināciju šīs pārvērtības škietami sasniedza 1937. gadā, kad K. Ulmanis svinēja 60 gadu jubileju. Viņš vienmēr bija alcis, lai sabiedrība viņa nopelnus Latvijas izveidē uzskatītu par nepārspētiem, un LU aprindās to labi zināja. Tagad LU augstākās raudzes pārstāvju publikācijas atainoja gluži vai idillisku vidi Latvijā un ideālu tautas vadoni. Tā, piemēram, tā brīža izglītības ministrs un Latvijas Vēstures institūta direktors profesors A. Tentelis sarakstīja slavinošu K. Ulmaṇa biogrāfiju, kurā viņu cildināja par "īsteno Latvijas tēvu", vadoni, kura katrs vārds sakṇojoties latviešu zemē un rodot atbalsi latviešu sirdī. ${ }^{101}$ Savukārt LU rektors J. Auškāps slavināja latviešu identitāti, vienotību, gara spējas un gribu nodoties zinātnei, dēvēja K. Ulmani par "mūsu valsts celtnes lielo arhitektu", kas tās augstā torṇa virsotnē iededzis "gaišo zinātnes lāpu”, savās uzrunās regulāri aicināja sekot "vadonim" nacionālās valsts stiprināšanā. ${ }^{102}$

Autoritārisma laiks radīja iespaidu, ka Latvijas sabiedrība, tostarp akadēmiskā vide un inteliǵence, ir harmoniski saliedēta. Turpretim agrāk, parlamentārisma gados, varēja rasties gluži pretējs iespaids. Tā, piemēram, publiski bija vērojams, ka ārpus LU aprindām nākušo izglītības ministru attiecības ar tādiem, kuri pārstāvēja LU, gandrīz vienmēr bija saspringtas, pat naidīgas. Demokrātijas un preses brīvības laiks to nekādi nevarēja noslēpt. Bijušā Filolog̣ijas un filozofijas fakultātes dekāna un ievērojamā latviešu diplomāta Arnolda Spekkes vārdiem izsakoties, LU parlamentārisma gados atradās "ideolog̣iski nacionālā frontē". ${ }^{103} \mathrm{Te}$ visai skaidras liecības ir saglabājušās par izglītības ministra J. Pliekšāna saspīlētajām attiecībām ar LU rektoru A. Tenteli. Rainis bija internacionālists, sociālists, un viņam nepatika A. Tenteḷa nacionālpatriotiskā vēstures koncepcija. Viņš sekmēja liberālisma izpausmi akadēmiskajā vidē, atbalstīja privāto augstskolu izveides idejas. 1926. gada februārī grāmatu apgāda vadītājs un Nacionālās operas direktors Ansis Gulbis vērsās pie LU Filologijas un filozofijas fakultātes ar ierosinājumu rekomendēt Raini Nobela prēmijai literatūrā. ${ }^{104}$ Latvijā tolaik valdīja uzskats, ka pieteikt kandidatūras prēmijai drīkst akadēmiskas institūcijas un augstskolas, kaut gan patiesībā to tolaik Eiropā darīja arī privātpersonas. ${ }^{105}$ LU nostāja šajā jautājumā bija noraidoša, tā izvairījās Raini izvirzīt prēmijai, to neizdarīja arī kāda cita institūcija vai privātpersona. ${ }^{106}$ Presē figurēja argumenti, ka Rainis iepriekšējā gadā 
neesot sarakstījis neko nozìmīgu, un arī iesnieguma termiņš 31. janvāris bijis nokavēts, tomēr par patieso iemeslu uzskatīja to, ka Rainis bija sociāldemokrāts un parlamentārisma periodā tika uzskatīts tikai par vienas škiras (strādniecības) dzejnieku, proti, par tādu, kas nereprezentēja visu sabiedrību. Šādu viedokli pauda, protams, labējā prese, tostarp Zemnieku savienības "Brīvā Zeme" un A. Berga "Latvis", kam simpatizēja latviešu akadēmiskā vide. ${ }^{107}$ Īpaši konsekventi pret Raini nostājās bijušais izglītības ministrs, LU prorektors un padomes loceklis, vēlākais Filologijas un filozofijas fakultātes dekāns, salīdzināmās valodniecības profesors J. Plāḳis, ${ }^{108}$ kurš visai bieži mēdza lekcijās zoboties par J. Pliekšāna pseidonīmu Rainis, stāstot, ka lietuviešu valodā tas nozīmējot "raibais", tā iespaidā J. Plāḳis bieži vinu ironiski saukājis par "tīǵgeri". ${ }^{109}$ Situāciju vēl saspringtāku padarīja tas, ka Rainis, līdzīgi kā visa M. Skujenieka kreisi centriskā valdība, atbalstīja ideju par vācbaltiešu veidotu privāto augstskolu - Herdera institūtu Rīgā (Herderinstitut zu Riga). Latviešu labējā inteliǵgence 1927. gadā centās bremzēt institūta likumprojekta izstrādi.

Šì epizode iezīmēja latviešu akadēmiskās vides politiskās noslieces. Vairākumam akadēmiskās vides pārstāvju bija raksturīgs konservatīvisms, ko 30. gados papildināja izteiktāka nacionāla ievirze. Tas gan neliedza viniem kādā politiskas dabas vai saimnieciskā jautājumā pieslieties kreisiem vai labējiem politiskiem uzskatiem.

30. gadu otrajā pusē sāka iezīmēties starptautiskās situācijas saspīlējuma kāpums, ko izraisīja Vācijas varenības atjaunošanās. K. Ulmaṇa valdības aprindas izlēma, ka šādā situācijā ir svarīgi veicināt patriotismu, sabiedrības militāro sagatavotību un atbalstu Latvijas armijai arī studentu vidē. 1937. gada 27. aprīlī valdība izdeva Noteikumus par militāro audzināšanu un militāro apmācību publiskās un privātās mācības iestādēs. ${ }^{110}$ Ar to valdība veica nozīmīgas korekcijas, LU programmā ieviesa militāro apmācību kā obligātu priekšmetu ar 40 stundām gadā un pakḷāva tai visus vīriešu kārtas studentus līdz 40 gadu vecumam, atskaitot vienīgi tos, kas strādāja valsts dienestā.

Šāda militārā apmācība bija jānodrošina un jāfinansē pašai augstskolai, organizējot priekšlasījumus, ekskursijas, piedalīšanos parādēs un svinīgajos aktos un citus līdzīgus pasākumus. LU visai kūtri iesaistījās militārās apmācības organizēšanā, jo tai nebija izdevīgi finansēt šādas papildu studijas. Turklāt liela dala profesoru un tostarp tradicionāli arī Universitātes vadība bija visai pacifistiski noskaņota. Kara resors kḷva uzstājīgs un kategorisks - Armijas štābs 1937. gada 25. oktobrī uzdeva jaunievēlētajam rektoram M. Prīmanim uzsākt militārās apmācības. ${ }^{111}$ Rezultātā militārai apmācībai LU sāka algot Armijas štāba izraudzītus lektorus. Sākotnēji to skaits bija apmēram 20 virsnieku, bet līdz 1940. gadam tas pieauga līdz 50. ${ }^{112}$ Nemot vērā, ka pirms K. Ulmaņa apvērsuma profesoru skaits LU nesasniedza vienu simtu, šādu militāro lektoru īpatsvars bija patiesi iespaidīgs. Lai arī valdības rīcība ir uzskatāma par racionālu ieguldijjumu Latvijas drošības un aizsardzības spēju vairošanā, varēja just, ka LU akadēmiskās aprindas uztvēra militāros lektorus ar skepsi, pat zināmu augstprātību. Militāro lektoru uzvedībai un zināšanām nereti bija neakadēmisks raksturs, viṇi pakḷāvās nevis akadēmiski godājamās Alma Mater normām un profesoriem, bet gan paši saviem Armijas štāba apmācības daḷas ieceltajiem galvenajiem lektoriem (līdz okupācijai tādi bija štāba kapteiņi Kārlis Mangulis, Teodors Galdiņš un Teodors Bebris). ${ }^{113}$

1939. gads nesa lielas pārvērtības valsts un Universitātes dzīvē. PSRS un Vācijas tuvināšanās dēḷ strauji mainījās starptautiskā situācija, 23. augustā tika noslēgts 
Molotova-Ribentropa pakts, tam sekoja PSRS karabāzu izveide, un 30. oktobrī tika noslēgts līgums par vācbaltiešu izceḷošanu uz Lielvāciju. Šie notikumi l̦oti strauji mainīja kadru un etnisko situāciju un vispārējo noskaņojumu LU. Gadu gaitā vācu mācībspēku skaits augstskolā jau tā bija samazinājies no maksimāli 58 līdz 29 izceḷošanas priekšvakarā, bet īpatsvars - no 14\% 1922.-1923. gadā līdz apmēram 5\% 1938.-1939. gadā. ${ }^{114}$ Tagad dažu nedēḷu laikā LU strauji zaudēja atlikušos vācu mācībspēkus. Jau pirmajā novembra nedēḷā izceḷošanai uz Vāciju pieteicās vairāk nekā puse vācu pasniedzēju. Vēl daži, kā, piemēram, ilggadējais Inženierzinātṇu fakultātes profesors, Eiropā atzìtais geodēzists A. Buholcs, izceḷoja vēlāk - 1941. gadā. ${ }^{115}$ Vienu no palikušajiem, Medicīnas fakultātes asistentu, kādreizējo brīvības cīnu dalībnieku vācbaltiešu landesvērā, Nikolaju Reinicu (Nikolai Reinitz), īsi pirms vācu karaspēka ienākšanas Rīgā nošāva Centrālcietumā par pretpadomju darbību. ${ }^{116}$ Cik zināms, tikai viens vācietis, Mehānikas fakultātes docents, elektrotehnikas speciālists Ludvigs Hunhens (Ludwig Hunchen), turpināja zinātnisko darbu vēl pēckara Latvijā, turklāt pēc savu tautas brāḷu izceḷošanas 1939. gada oktobrī kḷuva par tā saukto "ārkārtas" profesoru. ${ }^{117}$ Protams, izcel̦ošana attiecās arī uz vācu studentiem. Vācbaltiešu izcelıšanas rezultātā 1939. gada novembra sākumā visas LU fakultātes kopumā zaudēja 143 studentes, ${ }^{118}$ tomēr, kā atreferēja tālaika prese, izceḷot grasījās visi 250 LU studējošie vācieši un vācietes. ${ }^{119}$

Saistībā ar vācbaltiešu aizbraukšanu valdībai kopā ar LU bija steidzami jārisina aizbraukušo pasniedzēju aizstāšanas jautājums, jo studiju semestris jau bija sācies. Preses cenzūras un aizliegto sabiedriski politisko brīvību iespaidā klīda baumas, ka pēc vāciešu aizbraukšanas Latvijā radīsies inteliǵgentu darbinieku trūkums. Daži pat bija iedomājušies, ka pašreizējiem studentiem augstskolas vadība varētu noteikt samazinātas prasības, lai ātrāk aizpildītu tukšās amata vietas. ${ }^{120}$ Studijās prasības gan oficiāli netika samazinātas, toties rudens semestra vidū studiju procesā LU bija radies īsts juceklis. Izceḷotgribētājiem bija pāris nedēḷu laikā jāpabeidz viss iesāktais, un šajā saspringtajā situācijā katrs centās to atrisināt sev izdevīgākā veidā. Vakantas kḷuva nepieredzēti daudzas profesoru vietas. Radās izdevīgāka situācija tiem, kas kāroja iegūt augstāku amatu, turklāt bez īpašas konkurences no kolēguu puses. Valdība izdeva Latvijas vēsturē vēl nebijušu rīkojumu par masveida tā saukto "ārkārtējo" profesoru iecelšanu. ${ }^{121}$ Šis valdības solis ḷoti labi parādīja, cik spēcīga tomēr ir bijusi vācu izcelsmes profesoru nozīme LU līdz 1939. gada rudenim. Tiem aizbraucot, bija nepieciešama bezprecedenta profesoru kadru papildināšana. PSRS uzspiestais bāzu līgums un līgums ar Vāciju par vāciešu izcel̦ošanu, no vienas puses, radīja LU akadēmiskajā saimē bailes par nākotni un tuvojošos karu, bet, no otras puses, pēc vācbaltiešu aizbraukšanas radās unikāla iespēja 45 ilggadējiem latviešu pasniedzējiem strauji uzkāpt līdz akadēmiskās karjeras kāpṇu virsotnei - kḷūt par tā dēvētajiem "ārkārtas" profesoriem. Kā optimistiski rakstīja tālaika oficiālā prese: "Mūsu jauno zinātnieku kadrs sekmīgi aizstās aizbraucējus!"122 Viss notika tik strauji, ka pat nebija laika izdomāt, kā jaunpienākušos amatus pareizāk integrēt pastāvošo akadēmisko amatu un atalgojuma sistēmā un kā panākt, lai netiek pārkāpti akadēmiskie godīguma principi amatu ieñemšanā. Bija atlicis vairs tikai nedaudz vairāk kā pusgads, līdz Alma Mater, gluži tāpat kā visa valsts, tiks pakḷauta PSRS īstenotajai sovetizācijai. Ar to uz turpmākiem gadu desmitiem tika pārtraukta nacionālās universitātes dzīve. 


\section{ATSAUCES UN SKAIDROJUMI}

${ }^{1}$ Juridiski precīzu skaidrojumu par augstskolas priekštečiem 1927. gada 29. martā sagatavoja galvenais augstskolas juriskonsults, docents, vēlākais Latvijas Senāta (Augstākās tiesas) senators vācbaltietis Augusts Lēbers (August Loeber). Ar to noslēdzās vairākus gadus akadēmiskajās aprindās ilgušās diskusijas par augstskolas priekšteču nozīmi un patieso dibināšanas brīdi. Sk.: Sarakste ar Izglītības ministriju un ziņas par mācību spēku apbalvošanu ar Triju Zvaigžnu ordeni, par amata tērpu u. c., 1920.- 1938. Latvijas Nacionālais arhīvs, Latvijas Valsts vēstures arhīvs, Rīga (turpmāk - LNA LVVA), 7427-6-122, 70. lp.

${ }^{2}$ Latvijas Augstskolas organizācijas Padomes protokoli, 1919-1921. Ibidem, 7427-6-1, 19. lp.

${ }^{3}$ Ibidem, 97. 1p.

${ }^{4}$ RAIMONDS CERŪZIS. Latvijas vācu privātā augstskola "Herdera institūts" (1921-1939): izglītība, zinātne, tradīcija un ideolog̣ija. In: RAIVIS BIČEVSKIS (sast.). Heidegera Rīgas rudens: Martins Heidegers Rīgā. Rīga 2011, 269.-286. lpp.

${ }^{5}$ Latvijas Augstskolas organizācijas Padomes protokoli, 1919-1921. LNA LVVA, 7427-6-1, 40. lp.

${ }^{6}$ Ibidem, 2. 1p.

${ }^{7}$ Album Livonorum. Dorpat 1822-1939. [Lübeck] 1958, S. 301, 339.

${ }^{8}$ Paskaidrojums, Frīdrihs Brēdermans. In: Baltijas Ziṇas, 18.11.1918., 3. lpp.

${ }^{9}$ Ievērojama latviešu sapulce Rīgā. In: Dzimtenes Ziņas, 05.01.1918., 1.-2. lpp.; Pirmais Rīgas latviešu organizēšanās solis pēc vācu ienākšanas Rīgā. In: Baltijas Ziņas, 13.11.1918., 3. lpp.

${ }^{10}$ [Saraksts] Nr. 7., Kristīgā Nacionālā Partija. In: Baltijas Vēstnesis, 13.04.1920., 4. lpp.

${ }^{11}$ Von der akademischen Versammlung. In: Rigasche Zeitung, 10.12.1917., S. 3.

${ }^{12}$ Latvijas Augstskolas organizācijas Padomes protokoli, 1919-1921. LNA LVVA, 7427-6-1, 10. lp.

${ }^{13}$ P. Miḳelsons, Universitātes galvenais šveicars. In: Pēdējā Brīdī, 01.10.1935., 3. lpp.; 35 gados bez nokavēšanās. Rīts, 01.10.1935., 6. lpp.

${ }^{14}$ Acta der Baltischen Tehnischen Hochschule Riga. Betref. Verschiedenes, 1918-1919. LNA LVVA, 7145-4-8, 114. 1p.

${ }^{15}$ Ibidem.

${ }^{16}$ Sarakste ar Izglītības ministriju un ziṇas par mācību spēku apbalvošanu ar Triju Zvaigžņu ordeni u. c., 1920-1938. Ibidem, 7427-6-122, 42. lp.

17 JĀNIS VĒLIN̦š. Universitāte viṇam bija visa dzīve. In: Austrālijas Latvietis, 25.09.1970., 5. lpp.

${ }^{18}$ Gada pārskati par LU darbību, 1929-1939. LNA LVVA, 7427-6-39-1a-55, 78. lp.

${ }^{19}$ Materiāli par Politehniskā institūta pārṇemšanu Latvijas valsts rīcībā, 1919-1935. Ibidem, 7427-6-228, 32.-37., 178. lp.

${ }^{20}$ Ibidem, 92. 1p.

${ }^{21}$ Ibidem, 609.-610. lp.

${ }^{22}$ MĀRA KIOPE. Saruna ar Latvijas Universitātes pirmo rektoru profesoru Ernestu Felsbergu. In: SANDRA RANKA (sast.). Profesors Dr. phil. h. c. Ernests Felsbergs. Dzīve un darbs. Rīga 2004, 37.-43. lpp., šeit 42. lpp.

${ }^{23}$ O. Māzings vēlāk bija plaši pazīstams vietējā vācu kopienā, jo aktīvi pētīja Baltijas vāciešiem raksturīgos vārdus, runas un izteiksmju formas, vēlāk sagatavoja pat īpašu vārdnīcu. Pārgāja strādāt pie sava kolēǵa V. Klumberga vācu privātajā augstskolā Rīgā - Herdera institūtā.

${ }^{24}$ E. Veiss 1939. gadā izceḷoja uz Vāciju. Aus der Universität. In: Rigasche Rundschau, 27.10.1939., S. 5.

${ }^{25}$ E. Cimmermanis 1939. gadā izceḷoja uz Vāciju. Ibidem.

${ }^{26}$ V. Klumbergs vēlāk sarāva saikni ar Latvijas Augstskolu, aktīvi iesaistījās vācu privātās augstskolas, Herdera institūta, izveidē Rīgā un kḷuva par tās vadītāju lỉdz pat vācbaltiešu izceḷošanai 1939. gadā. 
${ }^{27}$ V. Vencelidesam starpkaru periodā piederēja $W$. Wencelides automobiḷu inženieru birojs, vin̄̌s tirgoja un remontēja prestižās Mercedes-Benz markas automašīnas, piedalījās autosacīkstēs ([Vencelidesa rīkotās automobiḷu sacīkstes - fotoreportāža]. In: Nedēḷa, 07.09.1923., 13. lpp.).

${ }^{28}$ Prof. Eižena Laubes personīgā lieta, LU Arhitektūras fakultāte. LNA LVVA, 7427-13-970, 13. lp.

${ }^{29}$ Latvijas Augstskolas organizācijas Padomes protokoli, 1919-1921. Ibidem, 7427-6-1, 12. lp.

${ }^{30}$ Pārskats par Latvijas augstskolas, vēlāk Universitātes, nodibināšanu un viņas darbību (1918-1929). Ibidem, 7427-6-37a, 262. lp.

${ }^{31}$ LU studentu statistika. LU studējošo skaits, 1919-1928. Ibidem, 7427-6-55, 564.-565. lp.

${ }^{32}$ Latvijas Augstskolas organizācijas Padomes protokoli, 1919-1921. Ibidem, 7427-6-1, 17. lp.

${ }^{33}$ Ibidem, 23. lp.

${ }^{34}$ Bijušā Rīgas politehniskā institūta pārṇemšanas komisijas protokoli (1919-1922). Ibidem, 7427-6-228, 423. lp.

${ }^{35}$ Zur Teuerung der Lebensmittel. In: Libauische Zeitung, 31.07.1920., S. 2; Verschiedenes, Die Preise in Riga. In: Libauische Zeitung, 17.08.1920., S. 2.

${ }^{36}$ Latvijas Augstskolas organizācijas Padomes protokoli, 1919-1921. LNA LVVA, 7427-6-1, 30. lp.

${ }^{37}$ Pārskats par Latvijas augstskolas, vēlāk Universitātes, nodibināšanu un viṇas darbību (1918-1929). Ibidem, 7427-6-37a, 113. lp.

${ }^{38}$ Ibidem, 103.-104. lp.

${ }^{39}$ Bijušā Rīgas politehniskā institūta pārṇemšanas komisijas protokoli, 1919-1922. Ibidem, 7427-6-229, 30.-31. 1p.

${ }^{40}$ Ibidem, 7427-6-228, 513. lp.

${ }^{41}$ Sarakste ar Izglītības ministriju un ziṇas par mācību spēku apbalvošanu ar Triju Zvaigžņu ordeni u. c., 1920-1938. Ibidem, 7427-6-122, 21., 26. lp.

${ }^{42}$ Ibidem, 31. lp.

${ }^{43}$ Prof. Eižena Laubes lieta. Ibidem, 7427-13-970, 193., 196. lp.

${ }^{44}$ Imanuela Bencingera lieta. Ibidem, 7427-13-153, 204., 210., 214. lp.

${ }^{45}$ Prof. Leonīda Arbuzova lieta. Ibidem, 7427-13-88, 127. lp.

${ }^{46}$ Pārskats par Latvijas augstskolas, vēlāk Universitātes, nodibināšanu un viņas darbību (1918-1929). Ibidem, 7427-6-37a, 103.-104., 385. lp.; Prof. Leonīda Arbuzova lieta. Ibidem, 7427-13-88, 36. lp.

${ }^{47}$ Izraksti no K. Morberga testamentāriem novēlējumiem, LU padomes protokoliem, K. Morberga radinieku lūgumi par pabalstiem, 1928-1931. Ibidem, 7427-8-12, 311. lp.

${ }^{48}$ Romas viesnīca Rīgā esot viena no vislabākām Eiropā - atzīst ārzemnieki. In: Centra Balss, 09.03.1934., 5. lpp.

${ }^{49}$ Der Ausbau des Hotels de Rome verzögert. In: Rigasche Rundschau, 04.12.1931., S. 6.

${ }^{50}$ Warum der Umbau des Hotel de Rome sich verzögert. In: Rigasche Rundschau, 07.12.1931., S. 10.

${ }^{51}$ Eröffnung des Hotel de Rome. In: Rigasche Rundschau, 10.09.1932., S. 10.

52 "Romas" atjaunošana. In: Latvijas Kareivis, 10.09.1932., 3. lpp.; "Romas" viesnīca un restorāns. Valdības Vēstnesis, 10.09.1932., 2. lpp.

${ }^{53}$ Romas viesnīca Rīgā esot viena no vislabākām Eiropā - atzīst ārzemnieki. In: Centra Balss, 09.03.1934., 5. lpp.

${ }^{54}$ Sarakste par Metropoles viesnīcas pārdošanu Latvijas Universitātei, 1940. LNA LVVA, 7427-8-20, 2. lp.

${ }^{55}$ Noteic jauno studentu uzṇemšanas kārtību. In: Latvijas Kareivis, 14.06.1940., 2. lpp. 
${ }^{56}$ Viesnīcas Metropol vācu īpašnieku izcelıošanas rezultātā to uz laiku slēdza, tās darbību atjaunoja jau pēc Latvijas inkorporācijas PSRS 1940. gada oktobrī. Sk. sludinājumus par viesnīcas darba atjaunošanu: Padomju Latvija, 01.10.1940., 13. lpp.; Cīna, 02.10.1940., 4. lpp.

${ }^{57}$ Gustava Ādolfa Celmiña studenta lieta. LNA LVVA, 7427-1-3546, 42 lp.

${ }^{58}$ RAIMONDS CERŪZIS. Latvieši un vācbaltieši starpkaru periodā: no kopīgas kultūras identitātes līdz "pieminekḷu karam”. In: Latvijas Vēstures Institūta Žurnāls 2015, Nr. 3, 65.-99. lpp., šeit 77.-78. lpp.

${ }^{59}$ Ibidem; ARvīDS RozentĀLS. Korporācijai Selonija 85 gadi. In: Londonas Avīze, 26.11.1965., 3. lpp.

${ }^{60}$ Augstskolas jautājums. In: Izglītība, 16.03.1919., 3. lpp.

${ }^{61}$ Ministru kabineta sēde [04.08.1919.]. In: Latvijas Sargs, 05.08.1919., 1. lpp.

${ }^{62}$ VANDA BRŪVele. Pauls Dāle. Dzīves lokos. In: Padomju Jaunatne, 22.07.1989., 4. lpp.; ZAIGA LAPIN̦A, AIJA PRIEDİTE. Uzticība garam... In: Karogs 1989, Nr. 7, 149. lpp.

${ }^{63}$ Ministru kabineta sēde [29.12.1919.]. In: Valdības Vēstnesis, 30.12.1919., 4. lpp.

${ }^{64}$ Viņa sieva īsi pirms Augstskolas atklāšanas aizsūtīja telegrammu uz Rīgu, ka vīrs Vācijā saslimis (Latvijas augstskolas rektors profesors Waldens. In: Latvijas Sargs, 27.09.1919., 3. 1pp.).

${ }^{65}$ FRICIS GULBIS. Vēl reiz "Valdena lietā". In: Latvijas Vēstnesis, 18.02.1924., 2. 1pp.; JURIS ZAḲIS. Nacionālās valstis un nacionālās universitātes. Referāts konferencē "Latvijas un Eiropas jaunās valstis: 1918-1939”, 06.11.1998. In: Latvijas Vēstnesis, 13.11.1998., 4. lpp.

${ }^{66}$ Latvijas augstskolas protests pret Bermonta uzbrukumu. In: Latvijas Sargs, 18.10.1919., 2. lpp.

${ }^{67}$ Latvijas nota par kara pieteikumu Vācijai, 25.11.1919. LNA LVVA, 2574-4-93, 122. lp.

${ }^{68}$ Georgs VīTols. Profesora Paula Valdena piemiṇai. In: Universitas 1957, Nr. 4, 71. lpp.; PAUL WALDEN. Wege und Herbergen: mein Leben. Hrsg. von Günter Kerstein. Wiesbaden 1974, S. 46-47.

${ }^{69}$ PAULS DĀLE (sast.). Vēsturisks pārskats par Latvijas Augstskolas nodibināšanu un vinas darbību pirmā (1919./20.) mācības gadā. Rīga 1921, 19. lpp.

${ }^{70}$ Sk., piem.: JĀNIS STRAdiN̦š. Trešā atmoda. Rīga 1992, 316.-331. lpp.; JĀNIS STRAdiN̦š. Akadēmiskā izglītība Baltijā un Latvijas Universitātes priekšvēsture. In: ALBERTS VARSLAVĀNS. (sast.). Latvijas Universitāte 75. Rīga 1994, 13.-44. lpp., šeit 40. lpp.

${ }^{71}$ Mācības līdzekḷi Latvijas Augstskolai. In: Latvijas Sargs, 12.08.1919., 1. lpp.; Mācības līdzekḷi Augstskolai. In: Latvijas Sargs, 17.08.1919., 1. lpp.; Profesors Valdens. In: Valdības Vēstnesis, 17.08.1919., 6. lpp.

${ }^{72}$ Polytechnikum. In: Rigasche Rundschau, 06.10.1905., S. 3; Aus der jüngsten Vergangenheit des Rigaschen Polytechnischen Instituts. In: Düna Zeitung, 07.09.1906., S. 1.

${ }^{73}$ Sarakste ar Rīgas apgabala Izglītỉbas pārvaldi par cīnu pret studentu saietiem u. c. (1904-1905). LNA LVVA, 7175-1-333, 166., 169., 179. 1p.

${ }^{74}$ P. Miḳelsons, Universitātes galvenais šveicars. In: Pēdējā Brīdī, 01.10.1935., 3. lpp.

${ }^{75}$ Auf der gestrigen Studentenversammlung. In: Rigasche Rundschau, 29.10.1905.; Acta des Verwaltungsrathes des Polytechnischen Instituts zu Riga betr. den Professor Gregor Schwartz. LNA LVVA, 7175-1-248, 50., 59. 1p.; Acta des Verwaltungsrathes des Polytechnischen Instituts zu Riga betr. den Docenten Alexander Döllen. Ibidem, 7175-1-200, 52.-54. lp.

${ }^{76}$ Acta des Verwaltungsrathes des Polytechnischen Instituts zu Riga betr. den ordentlichen Professor Paul Walden. LNA LVVA, 7175-1-274, 64. 1p.

${ }^{77}$ Ibidem, 91. lp.

${ }^{78}$ Das Rigaer Polytechnikum. In: Rigasche Zeitung, 17.07.1919., S. 1; WALDEN, Wege und Herbergen, S. 46-47. 
${ }^{79}$ Sk., piem.: Sarakste ar Rīgas apgabala Izglīiības pārvaldi par cīn,u pret studentu saietiem u. c. (1904-1905). LNA LVVA, 7175-1-329, 3., 150.-151., 256.-257., 449.-451., 492.-493., 522., 549.-551. lp.

${ }^{80}$ Latvijas izglītības biedrības augstskolu sekcijas sēde. In: Latvijas Sargs, 03.02.1920., 3. lpp.

${ }^{81}$ Rīga, Universitātes padomes sēde. In: Latvis, 22.02.1924., 5. lpp.; Profesors Valdens [lapas atvērums, veltīts vieslekcijas norisei Rīgā]. In: Nedēla, 09.05.1924., 5. lpp.

${ }^{82}$ GuLBIs, Vēl reiz "Valdena lietā".

${ }^{83}$ FRICIS GulBIS. Kāds vārds "Valdena lietā”. In: Latvijas Vēstnesis, 05.02.1924., 2. lpp.; GuLBIS, Vēl reiz "Valdena lietā".

${ }^{84}$ Ernests Rolavs, pa 1905. gada tekām. In: Kurzemes Vārds, 18.01.1940., 5. lpp.

${ }^{85}$ KĀRLIS BALODIS. Valdena lietā. In: Latvijas Vēstnesis, 09.02.1924., 6. lpp.; KĀRLIS BALODIS. Mans beigu vārds Valdena lietā. In: Latvijas Vēstnesis, 20.02.1924., 5. lpp.

${ }^{86}$ HenRIJS Simsons. Pauls Valdens. In: Latvijas Vēstnesis, 10.05.1924., 5. lpp.

${ }^{87}$ H. Simsons izveselıjies. In: Pirmdienas Rīts, 06.08.1928., 1. lpp.; JĀNIS ANDRUPS. Kas bija Henrijs Simsons? In: INESE AuZIN̦A-SMITA (red.). Latvieši Lielbritānijā. Londona 1995, 21.-24. lpp.

${ }^{88}$ DĀLE, Vēsturisks pārskats par Latvijas augstskolas nodibināšanu, 76. lpp.

${ }^{89}$ Ibidem.

${ }^{90}$ Likvidējama fakultāte. In: Sociāldemokrāts, 01.01.1928., 1. lpp.; Latvijas Sociāldemokrātiskās Strādnieku partijas jaunā programma. In: Sociāldemokrāts, 03.07.1930., 4. lpp.

${ }^{91}$ Izglītîbas ministrijas vadītāji no 1918.-1938. g. In: Audzinātājs. Paidagoǵiski sabiedrisks mēnešraksts 1938, Nr. 11, 578. lpp.

${ }^{92}$ Latvijas Universitāte 1919-1929. Latvijas Universitātes izdevums. Rīga 1929, 532.-533. lpp.

${ }^{93}$ LŪCiJA BĒrziñA-Felsberga. Profesors Ernests Felsbergs. Atmiņas. In: RANKA, Profesors Dr. phil. h. c. Ernests Felsbergs, 50.-76. lpp., šeit 61. lpp.

${ }^{94}$ Nacionālās apvienības kandidātu saraksts Nr. 4. In: Latvis, 08.02.1925.; BĒRZIN̦A-FELSBERGA, Profesors Ernests Felsbergs, 61. lpp.

${ }^{95}$ Miris profesors Dr. Kārlis Balodis. In: Sociāldemokrāts, 14.01.1931., 3. lpp.

${ }^{96}$ Latvijas Darba Savienības un Tautas Apvienības saraksts. In: Jaunā Diena, 30.09.1928., 4. lpp.

${ }^{97}$ Prof. K. Balodis miris. In: Latvijas Kareivis, 14.01.1931., 3. lpp.

98 Jokupēteri [karikatūra]. In: Svari, 31.10.1924., 350. lpp.

${ }^{99}$ Pamazām, palēnām... In: Svari, 29.11.1929., 378. lpp.; Zieǵeḷa glabātājs [karikatūra]. In: Svari, 28.06.1929., 207. lpp.; Dep. profesors K. Balodis atteicies no deputāta algas [karikatūra]. In: Svari, 15.03.1929., 83. lpp.

${ }^{100}$ Vakarējais lauvas. In: Svari, 13.02.1931., 50. lpp.; Sludinātājs Dr. P. Zālīte. In: Svari, 03.04.1931., 107. lpp.; Deputāta kaislība. In: Svari, 12.06.1931., 183. lpp.; Neticama lieta. In: Svari, 14.08.1931., 242.-243. lpp.

${ }^{101}$ Augusts Tentelis. Tautas vadoṇa dzīve un personība. In: Latvijas Vēstures Institūta Žurnāls 1937, Nr. 3, 325.-334. lpp., šeit 329.-330. 1pp.

102 JŪLIJS AUŠKĀPS. Latviešu gars un zinātne. In: Sējējs 1937, Nr. 11, 1129.-1136. lpp., šeit 1132., 1135. lpp.; JŪLIJS AUŠKĀPS. Par gara cīṇu. In: Sējējs 1936, Nr. 11, 1147.-1152. lpp.

${ }^{103}$ ARNOLDS SPEKKE. Atmiņas par Latvijas Universitātes Filoloǵijas un Filozofijas Fakultātes sākumiem un izveidošanos. In: Universitas 1966, Nr. 17, 5.-8. lpp.

104 J. Rainis - kandidāts uz Nobela prēmiju. In: Sociāldemokrāts, 19.02.1926., 1. lpp.; Raiṇa kandidatūra uz Nobela prēmiju. In: Sociāldemokrāts, 23.03.1926., 1. lpp.

${ }^{105}$ ARNO Jundze. Provinces drāma. Kā Raini Nobela prēmijai (ne)izvirzīja. In: Neatkarīgā Rīta Avīze, 23.02.2015., 10.-11. lpp. 
106 JundZe, Provinces drāma, 10.-11. 1pp.

${ }^{107}$ Nošāvuši greizi [par Raiņa virzī̌anu Nobela prēmijai]. In: Latvis, 27.03.1926., 1. lpp.; Vai tiešām Rainis - Nobela prēmijas laureāts? In: Latvijas Sargs, 17.03.1926., 2. lpp.; J. Rainis kā Nobela prēmijas kandidāts. In: Brīvā Zeme, 18.03.1926., 3. lpp.; Māksla. Par Raini. In: Brīvā Zeme, 22.03.1926., 3. lpp.

${ }^{108}$ Latvijas Universitāte 1919-1929, 178.-179. lpp.

${ }^{109}$ KĀRLIS DZIḶLEJA. Raiņa tēls mūsu literatūrā. In: Domas, 01.07.1930., 123.-128. lpp., šeit 127.-128. lpp.

${ }^{110}$ Noteikumi par militāro audzināšanu un militāro apmācību publiskās un privātās mācības iestādēs. In: Valdības Vēstnesis, 27.04.1937., 1. lpp.

${ }^{111}$ Apmācības plāni, programmas, noteikumi u. c. par studentu militāro audzināšanu un apmācību (1937-1940). LNA LVVA, 7427-6-232, 7. lp.

112 Ibidem, 186., 207., 246.-247. lp.

${ }^{113}$ Ibidem, 263., 164. lp.

${ }^{114}$ Dĩtrins A. LĒBers. Vācbaltiešu mācību spēki Latvijas Universitātē (1919-1941). In: RENĀTe Adolfi (sast.). 800 gadi. Mūsu kopējā Rīga. Vācbaltiešu autoru apcerējumi. Rīga 2001, 145.-164. lpp., šeit 146., 148. lpp.

${ }^{115}$ Deutsche Lehrkräfte der Universität nehmen Abschied. In: Rigasche Post, 22.10.1939., S. 3; Arī studijas pārtraukušie varēs iegūt zinātnisko grādu. In: Brīvā Zeme, 26.10.1939., 2. lpp.; Aizbraucēju skaits jau sasniedz 40585. In: Jaunākās Ziņas, 28.11.1939., 5. lpp.; LĒBERS, Vācbaltiešu mācību spēki Latvijas Universitātē (1919-1941), 149.-162. lpp.

116 [Sēru sludinājums par N. Reinicu]. In: Tēvija, 07.07.1941., 1. lpp.; Rīgas Centrālcietumā atrasti 98 upuri. In: Kurzemes Vārds, 09.07.1941., 1. lpp.; Par ko noslepkavoja latviešu patriotus. In: Daugavpils Latviešu Avīze, 18.07.1941., 1. lpp.

117 Zinātni - darba ḷaudīm! In: Cīṇa, 07.11.1944., 7. lpp.; LĒBERs, Vācbaltiešu mācību spēki Latvijas Universitātē (1919-1941), 154. lpp.

${ }^{118}$ Vācu tautības repatriējošo studentu saraksts (1939). LNA LVVA, 7427-6-232, 258. lp.

${ }^{119}$ Vācu tautības mācības spēki. In: Jaunākās Ziṇas, 21.10.1939., 15. lpp.; Deutsche Lehrkräfte der Universität nehmen Abschied. In: Rigasche Post, 22.10.1939., S. 3.

${ }^{120}$ Mūsu jauno zinātnieku kadrs sekmīgi aizstās aizbraucējus. In: Latvijas Kareivis, 05.11.1939., 1. lpp.

${ }^{121}$ Pirmie ārkārtējie profesori un mag̣istri. In: Brīvā Zeme, 12.10.1939., 2. lpp.

${ }^{122}$ Mūsu jauno zinātnieku kadrs sekmīgi aizstās aizbraucējus, 1. lpp.

\section{SUMMARY}

The University of Latvia was founded on the late summer of 1919 and opened its doors to the students on September 28. This happened shortly after the end of an important stage in Latvia's so-called freedom fight or War of Independence. From that moment on, the Baltic Germans, who had a leading influence in the history of the Baltics, gradually lost their authority. At the beginning of the university formation, the Baltic Germans also had a great influence in this educational institution. The University of Latvia inherited a lot from its predecessor, the Riga Polytechnic Institute. The new university also took over the principle of examinations typical of tsarist Russia (division of the study year into periods of active studies and exams). Most of the teaching staff were German speakers, but the language of lectures until the beginnings of new national university was Russian. 
The majority of former teachers of Latvian origin at the Riga Polytechnic Institute also appreciated German culture and identity. A typical example here is the director of the Institute and the first head of the Latvian University, professor of chemistry Paul Walden (Valdens). He did not believe that Latvians would be able to create their own university and science, and did not even consider it possible to conduct a proper study in Latvian. Very soon Baltic German teachers were supplemented with new Latvian employees. Some of them returned from abroad, others quickly formed a career in Latvia on the spot.

As in society, the interpretation of past events was a very important issue in Latvian professors' community. For the last fifty years, Latvians had systematically tried to achieve the same rights as the great nations of Europe. A particular tension was the 1905 revolution and its repression form local administration and institutions. This event also had an impact on the establishment of the university, since, for example, P. Walden was actively involved in the persecution of revolutionary students in Riga Polytechnic Institute. Now these students had become professors.

There are many similarities between the history of the Latvian state and the national university. We can observe the same stages of development in the history of the university and within the state as a whole. This applies to both the economic situation and politics. After the World War and the War of Independence, the Latvian economy, especially industry, had partially collapsed. The difficult economic situation had a negative impact on the university staff - its financial resources were insufficient; salaries were low, and professors could not even buy the bare sustenance. The significant financial resources of the predecessor of the University of Latvia, Riga Polytechnic Institute, disappeared during the war and could not be recovered. In the mid-1920s, the economic situation improved rapidly. Furthermore, the financial situation of the institution improved as it received a heritage from the entrepreneur Kristaps Morbergs, which included both financial resources and profitable real estate (for example, the best regional hotel in the northeastern Europe "Hotel de Rome" in the city of Riga along with its famous luxury restaurants). In the middle of the thirties, a professor was already a prestigious profession in Latvia. The professor's salary was comparable to the minister's salary. University professors made a significant contribution to strengthening the identity of the new state and actively participated in the political life. Many university lecturers were from different, mostly liberal, and centrist political parties (except social democrats), and became members of the parliament (Saeima). The first President of Latvia, lawyer Jānis Čakste, was also a professor at the University of Latvia. Later, during the years of authoritarianism, the teaching staff of the university formed Latvia's educational, scientifical and cultural policy. The professors at the university were all three ministers of education of the authoritarian period (professor of theology, dean of the faculty Ludvigs Adamovičs, professor of history, rector Augusts Tentelis, professor of chemistry, dean, rector Jūlijs Auškāps). Thus, the authority of the national higher education institution in the field of education policy during this period was indisputable, it can even be said that the education and science policy of the authoritarian period was shaped by the professors of the university. The University of Latvia even partly formed the entire ideology of authoritarianism in Latvia, including the so-called "leader cult" of authoritarian leader Kārlis Ulmanis. 


\title{
lek!̣aušanās. Dažas epizodes Latvijas jūrnieku profesionālajās gaitās trimdā Rietumos. I dạ̣a
}

\author{
The Integration. A Few Episodes of the Professional Ways of Latvian \\ Seamen in the Western Exile. Part 1
}

\author{
Dāvis Beitlers, Mg. hist. \\ Latvijas Universitātes Vēstures un filozofijas fakultātes doktorants \\ Rīgas vēstures un kuğniecības muzeja vēsturnieks \\ Palasta iela 4, Rīga, LV-1050 \\ E-pasts: davis.beitlers@tvnet.lv
}

Šis raksts turpina saistītas tematikas publikāciju ${ }^{1}$ žurnāla iepriekšējā numurā un stāsta par tiem starpkaru Latvijas Republikas pilsoṇiem, kuri Otrā pasaules kara un tā atskaņu laikā nonāca un palika Rietumu pasaulē, kur - jau kā trimdinieki - turpināja vai tikai sāka jūrnieka gaitas, pamazām iekḷaujoties mītnes valstu saimnieciskajā un profesionālajā, sociālajā un sabiedriski politiskajā vidē un struktūrās. Rakstā iezīmētas dažas no problēmām, kas pavadīja latviešu jūrniekus - trimdiniekus šìs "ieaugšanas" gaitā, ieskicēti daži jūrnieku veiksmes stāsti un viena otra pētniecības problēma, kas ieaužas trimdas vēstures izpētes problemātikā kopumā.

Atslēgvārdi: latviešu trimda, jūrniecība, pilsonība, politiskā uzticamība, tautsaimnieciskais protekcionisms.

This article is a continuation of publication released in the previous issue of the journal. About it discusses the position of citizens of the interwar Latvian Republic, who during and after the Second World War went into exile to the Western countries and continued or began the seafaring occupations. Gradually they became a part of the economical, professional, social-political environment and structures of their new homelands. The article outlines some of the problems of this phenomenon, a few successes of the Latvian exile sailors, and also some problems encountered in the course of the research dedicated to this theme that also involves the problematic of the research on Latvian exile history as a whole.

Keywords: Latvian exile, maritime, citizenship, political loyalty, economic protectionism.

Ja kaut pavirši pārlapojam latviešu trimdas vēsturei veltītās apceres un trimdinieku atminu pierakstus, redzams, ka latvieši tikai pamazām iekaroja savu vietu jauno mītnes valstu profesionālajā vidē 
un tautsaimniecībā un pirmajos svešuma gados - pat par spīti teicamai izglītībai bieži bija spiesti samierināties ar pavisam vienkāršiem darbiem. Gana sarežǵìts profesionālais ceḷš bija jānoiet arī trimdā nokḷuvušajiem latviešu jūrniekiem. Daži kug̣inieki pēc kara pat bija spiesti pārkvalificēties un turpināt amatu kādā citā nozarē, bet vairāk, šķiet, tomēr bija to, kam izdevās savas jūrnieka gaitas turpināt. Vieni vismaz kādu laiku turpināja braukt uz latviešu vai bijušajiem neatkarīgās Latvijas kug̣iem, citi jau drīz pēc kara pārgāja svešu valstu un sveštautiešu rēderu dienestā.

Tas, vai un cik lielā mērā latviešu jūrnieki varēja turpināt vai uzsākt jūrnieka gaitas "brīvās pasaules" valstu kug̣niecībā, bija atkarīgs no valstu nostājas un imigrācijas politikas, politiskajām simpātijām un antipātijām, no pašu latviešu (un it îpaši jūrnieku) centības un mākas aizstāvēt savas tiesības un vēlmes saglabāt dalîbu pasaules jūrniecības nozarē, no latviešu jūrnieku sociālekonomiskā tēla veidošanās svešzemnieku atbildīgo amatpersonu un privāto rēderu acīs, kā arī pašu latviešu sabiedrībā. Daudzi profesionālie apgrūtinājumi, ar ko nācās saskarties latviešu jūrniekiem Rietumvalstīs, tērpās saimnieciskā protekcionisma politikas drānās ar nolūku aizsargāt pilsonu intereses grūtajos pēckara apstākḷlos, tomēr arī tie bieži vien vismaz daḷeji sakṇojās politiskos un ideologiskos motīvos.

\section{Latviešu jūrnieks - ienācējs Eiropas tautsaimniecībā}

Pirmais un svarīgākais faktors, kas apgrūtināja latviešu jūrnieka sekmīgu darbību "brīvajā pasaulē", neapšaubāmi bija valstu saimnieciskā situācija pēckara apstākḷos un nostāja pret latviešu jūrniekiem kā viesstrādniekiem, kas pirmajos pēckara gados, protams, saistījās arī ar Rietumu sabiedroto diktētās pēckara pasaules jaunās kārtības nostādnēm. Uzskatāmi šādas tendences piemēri ir divas baltiešu jūrnieku lietas Skandināvijā.

Zviedrijā latviešu jūrnieku intereses apdraudēja impulss no valsts vai pat starptautiskām iestādēm: 1945. gada maija beigās, neilgi pēc kara beigām, Sabiedroto kontroles komisija Gēteborgā atteicās piencemt darbā vairākus simtus Zviedrijā esošo baltiešu jūrnieku (kopā ar igauṇiem tādu bija vismaz 1000), lai arī vakanču nav trūcis. Tiesa, kad igaunu jūrniecības nozares pārstāvji neizpratnē vērsās pie starptautiskās Jūrnieku ūnijas (apvienības) Londonā - Sabiedroto valstī, izrādijjās, ka tā neko par šādu aizliegumu nav zinājusi. ${ }^{2}$ Tajā pašā laikā gribētos domāt, ka vietējās Zviedrijas amatpersonas nebūtu rīkojušās pretrunā ar augstākiem lēmumiem, bet, lai arī kā būtu bijis, diezgan drīz aizliegums tika atcelts: vasaras beigās atḷauju strādāt uz zviedru tirdzniecības kug̣iem saṇēma pirmie latviešu jūrnieki (pagaidām gan tikai trīs - Valdis Viḷumsons, Andrejs Šķerbergs un Vilnis Zāraks), ${ }^{3}$ bet pēc dažiem gadiem latviešu trimdas prese jau varēja rakstīt, ka "daudz latviešu jauneklu tagad brauc uz [zviedru un citu "brīvās pasaules" valstu] kuǵiem". ${ }^{4}$ To, ka stingrie priekšraksti ar laiku atslāba, visdrīzāk sekmēja 40. gadu otrajā pusē valdošais kvalificētu jūrnieku trūkums Zviedrijā (jūrnieku trūka tik l,oti, ka vajadzēja pat ievest jūrskolu absolventus no Vācijas). Tiesa, Zviedrijas varas iestāžu piesardzība, nodarbinot nezviedru jūrniekus, saglabājās arī 50. gados un tika vērsta pret visu tautību ārzemniekiem; piemēram, ikvienam ārzemniekam, lai iegūtu Zviedrijā atzītu jūrnieka izglìtību, attiecīgu sertifikātu un pēc tam varētu kuǵot zviedru flotē, bija nepieciešama ipaša atḷauja no Zviedrijas Tirdzniecības kolēǵijas (Kommerskollegium). ${ }^{5}$ Jādomā, ka šāda piesardzība bija normāla prakse daudzās pasaules valstîs, jo tā vērojama arī pret ārzemju un Baltijas bēgḷu jūrniekiem labvēlīgākajās lielvalstīs ASV 
un Lielbritānijā, kuru valdība arī pieprasīja potenciālajiem flotes darbiniekiem iziet īpašu sertifikāciju pēc ārzemju jūrskolas absolvēšanas (iespējams, šai ziṇā bija arī izṇēmumi). ${ }^{6}$

Mazliet atškirīga situācija vērojama Norvēgijā 1949. gadā - tātad vairākus gadus vēlāk nekā Zviedrijā: tur valsts iestādes, bloḳēdamas latviešu iespēju tikt uzn,emtiem norvēǵu flotes dienestā, atsaucās sabiedrisko organizāciju un konkrētu vietējo nozares darbinieku grupu ierosmēm. Situācija šāda. 1949. gada pavasarī Baltiešu jūrskolas administrācija Flensburgā ar Starptautiskās Bēgḷu aprūpes organizācijas (International Refugee Organisation - IRO $)^{7}$ starpniecību $^{8}$ principiāli vienojās ar ekspluatācijā jaunnododamā Norvēgijas tvaikoṇa Skaugum kapteini un rēdereju, ka tā apkalpe tiks pilnībā vai gandrīz pilnībā komplektēta no baltiešu jūrskolas tā gada absolventiem; ${ }^{9}$ tomēr, lai arī prese jau laikus to kā atzīstamu panākumu paspēja jūsmīgi izsludināt visā "brīvajā pasaulē", ${ }^{10}$ ceḷā nostājās Norvēgijas jūrnieku arodbiedrība, likumiski panākot, ka kuğa īpašnieki norvēǵu rēdereja - pārvietotās personas tomēr darbā nepieñem. ${ }^{11}$ Saasināto situāciju mazliet mīkstināja vienīgi panāktais kompromiss: no pārvietoto personu (displaced person) nometṇu iemītniekiem tika sakomplektēts kuğa medicīniskais personāls. ${ }^{12}$

Pēckara gadu bieži vien smagajā saimnieciskajā situācijā bija tikai normāli, ja latviešu jūrnieki gluži tāpat kā citu nozaru profesiju pārstāvji, nereti spītējot augstai izglītībai un kvalifikācijai, kas būtu piemērota labi atalgotiem amatiem, bija spiesti pildīt vienkāršākus un sliktāk atalgotus darba pienākumus. Tā kāds latviešu jūrnieks, apmeklējis savus tautiešus un amatbrālus pārvietoto personu nometnēs Vācijā 1945. gada rudenī, ziṇoja, ka

"latviešu lielākās rūpes ir darba un iztikas jautājums. Ar darba atrašanu ir l̦oti grūti.
To dabūt kaut kur pie vāciešiem ir neiespējami, jo visa Vācijas dzìve ir galigi ruinēta. Arī pašu vāciešu stāvoklis ir l̦oti grūts. [...] Labāk klājas tiem latviešiem, kas saistījušies darbā kādā sabiedroto iestādē. [...] trūkst informācijas par notikumiem pasaulē, valda neziña par nākotni [...].”

Turklāt jūrnieku darbība esot bijusi īpaši apgrūtināta Sabiedroto noslēgtās piekrastes dēḷ (Šlēsvigas-Holšteinas apgabalā). ${ }^{13}$

Darbvietu deficīts pēc kara bija asi vērojams arī Zviedrijā, un šādos apstākḷlos, kad bija grūti nodrošināt ar darbu pat savus tautiešus, iebraucējs, protams, ne uz kādu zelta bedri darba tirgū cerēt nevarēja. Labi, ja, pateicoties nozares attīstībai un darbaspēka pieprasījumam, augsti izglītotam latviešu jūrniekam šajā zemē bija iespējams darboties savā nozarē kā kug̣u bortu krāsotājam vai vidēja ranga mehāniḳim un būvniekam kādā kuğu būvētavā vai remontdarbnīcā; jau 1945. gada rudenī visas vakances, kurās latviešu jūrnieks varēja kaut puslīdz darboties savā nozarē, vismaz Gēteborgā bija pilnībā aizpildītas. ${ }^{14}$ Turklāt 40. gadu otrajā pusē Zviedrijā latviešu bēg̣̣iem bija daudz lielākas iespējas meklēt darbu nekā pārvietotajām personām nometnēs. ${ }^{15}$ 1948. gadā, norādot uz bēgḷ nodarbinātības lielo nozīmi vēl naivu dzimtenes jauncelsmes cerību gaismā, ievērojamais tautsaimnieks profesors Jānis Vārsbergs (1879-1961) rakstīja:

"Šeit, Zviedrijā, bēgli var būt apmierināti, jo, kas var un grib strādāt, tas nopelna sev iztiku, nav jāslaistās bezdarbībā, kas beidzot vājina spēkus un nomāc garu. Daudzi Vācijas nometnēs mitošie ir zaudējuši daudz no savām spējām, un, kad atskanēs sauciens doties uz dzimteni, tad dažs labs tai maz ko varēs pārvest. No Vācijas iebraukušie l̦oti priecīgi, ka te var strādāt, ja dažkārt arī darbs nav visai piemērots, tomēr eksistence 
nodrošināta un, galvenais, apziña, ka neesi citiem uz kakla."16

Jādomā, ka profesora vēstule attiecināma arī uz latviešu jūrniekiem. Tā kā trūka kvalificētu jūrnieku, kaut vai pagaidu darbu pēckara gados latviešu jūrnieki - vismaz diplomētie - varēja atrast arī uz dāṇu kug̣iem, pat neṇemot vērā Dānijas politiskās simpātijas pret Padomju Savienību. ${ }^{17}$

Bēg̣̣a statuss latviešu jūrnieku nodarbinātību apgrūtināja vēl kādā aspektā. IRO noteikumi par pārvietoto personu nodarbināšanu paredzēja, ka, līgumam beidzoties, personas nav sūtāmas atpakaḷ uz Vāciju, uz pārvietoto personu nometnēm, bet gan izvietojamas kādā no emigrācijas zemēm, kur acīmredzot nodrošināmi arī zināmi labvēlīgi priekšnoteikumi vinu tālākai palikšanai noteiktajā vietā, turklāt īpašniekam tas bija jāgarantē, parakstot īpašu garantijas vienošanos - tā dēvēto afidevìtu. Piemēram, kug̣īpašniekam ar ASV pilsonību šādā gadījumā bija jādodas uz Vašingtonu un jāgarantē, ka tad, kad darba attiecības beigsies, jūrnieks ar visu gimeni (!) varēs saṇemt patvērumu kādā no ASV ostām. Praksē tas nozīmēja ne tikai lieku apgrūtinājumu, nodrošinot dzīvesvietu, bet arī ierobežojumus kug̣a pierakstišanā valstīs, kuras pārvietotās personas nelabprāt "ņēma pretim", bet kurās valdīja kuǵniecības uzṇēmējdarbībai saimnieciski izdevīgāki nosacījumi. Tādēḷ pārvietoto personu pieñemšana darbā daudziem Rietumvalstu kug̣niecības uzṇēmējiem varēja šḳist pārāk liels slogs, no kura visvieglāk bija izvairīties, bēĝ̣lus darbā nepieṇemot (kādēl gan sevi lieki apgrūtināt?!). ${ }^{18}$

Protams, bija arī gadījumi, kad pārvietotās personas statuss un starptautisko bēgl̦u aprūpes un aizgādniecības organizāciju aizmugure izrādījās par svētību - vispirms tiem latviešu jūrniekiem (un ne tikai jūrniekiem), kas bija nolēmuši laikus atstāt Eiropu un jau pirms pārvietoto personu nometṇu slēgšanas nogruntēties "apsolītajā zemē" - ASV. Proti, šīs Rietumu superlielvalsts valdība bija noteikusi stingrus ierobežojumus ieceḷotāju plūsmai - tā dēvētās imigrācijas kvotas. 1945.-1947. gadā Latvijas pavalstnieku (vispār) ieceḷošanas kvota bija 263 cilvēki gadā, no tās 90\% ik gadu bija rezervēti tieši t. s. pārvietotajām personām, kas Vācijā izmitinātas amerikāṇu okupācijas joslā un uzturas tur kopš 1945. gada 1. decembra. ${ }^{19} \mathrm{Un}$, protams, katram svešzemniekam, kurš vēlējās valstī ieceḷot ārpus šīm kvotām, draudēja smagnēja un ilgstoša imigrācijas dokumentu kārtošana, lai iegūtu uzturēšanās atlauju, ko ievadīja vīzas pieprasījums ASV konsulātā. Pārvietoto personu uzturēšanos ASV vēl vairāk atviegloja 1948. gadā pienemtie grozījumi ASV Imigrācijas likumā - tā saucamais "Pārvietoto personu akts" (Displaced Persons Act of 1948) ar paplašinātu jeb nostiprinātu pārvietotās personas statusa definīciju. Pateicoties tam, ar 1948. gadu ieceḷošana ASV kḷuva mazliet plašāka: pirmkārt, iecel,ot tagad varēja arī franču un britu okupācijas joslu iemītnieki, ${ }^{20}$ un, otrkārt, tika atvieglota pastāvīgās uzturēšanās dokumentu - imigrācijas vīzu - iegūšanas procedūra: šādu dokumentu tagad varēja saṇemt ikviena pārvietotā persona, kas ASV ieceḷoja vai jau uzturējās bēgḷa statusā. ${ }^{21}$

Pārvietotās personas statuss bija liels ieguvums arī britu okupācijas joslas iemītniekiem. Piemēram, politiski šaubīgās zaudētājvalsts nācijas - vācu - jūrniekiem bieži vien nebija atḷauts braukt uz tāljūras kuǵiem, taču visi latviešu jūrnieki, kas mita britu kontrolētajā Vācijas dạ̄ā, bija registrēti Hamburgas jūras darba pārvaldē un baudīja tiesības izbraukt no okupācijas joslas katrā laikā uz visiem kuǵiem. ${ }^{22}$ To vēl vairāk sekmēja vietējo jūrasbraucēju trūkums, kas valdīja Lielbritānijā pirmajos pēckara gados. Kā atmin̄ās pasvītro tāljūras kapteiṇa Krišjāṇa Rūdolfa 
Slejas (1907-1994) meita Rita Jefimova (dz. Sleja, 1935), tad Lielbritānija bija viena no pirmajām Eiropas valstīm, kas pavēra iespējas latviešu jūrniekiem iemantot labas darbvietas un tā nereti iekārtoties krietni atalgotos posteņos ātrāk nekā daudziem citiem nometniekiem - sauszemes profesiju pārstāvjiem. ${ }^{23}$

Tomēr saiknē tieši ar rangos augstāku jūras amatu pārstāvjiem jeb kug̣a virsniecību briti izcēlās ar caurmērā visai stingru politiku. Cik zināms, ilgstoši - gan pirms Otrā pasaules kara, gan vēlāk, līdz pat mūsdienām -, lai varētu pilnvērtīgi kugoot valsts flotē, paaugstinot sertifikāciju un kāpjot pa rangu kāpnēm, bijusi nepieciešama pilsonība. Un tieši pilsonība zināmā mērā ir atslēgvārds daudzās latviešu jūrnieku problēmās Rietumos pēc Otrā pasaules kara. Pilsonības iegūšana Rietumeiropā (tiesa, ne tikai), kur totālais vairākums latviešu bēgḷu nonāca vispirms, parasti aizṇēma vairākus gadus. Kā atceras ilggadējais tāljūras kapteinis Imants Balodis (19242001), kurš 1954. gadā apmetās uz dzīvi Kanādā, tad 50. gados Lielbritānijā šādas pilsonības iegūšanai bija nepieciešami pieci gadi - tas bija būtisks šķēerslis latviešu jūrnieku pilnvērtīgai nodarbinātībai šajā zemē. ${ }^{24}$ Protams, bija arī veiksmes stāsti. Piemēram, ar Latvijas sūtṇa Londonā un Latvijas diplomātiskā un konsulārā dienesta vadītāja trimdā Kārḷa Zariṇa (18791963) gādību kuǵa virsnieka - trešā mehāniķa (inženiera) - posteni uz kāda angḷu kug̣a uzreiz pēc nonākšanas Lielbritānijā 1946. gadā ieguva latviešu jūrnieks Ādolfs Cel̦doma (1917-2011), kurš pēc pieciem gadiem, kad bija iemantojis Lielbritānijas pilsonību, posteni paaugstināja līdz pirmajam mehānikịim (inženierim). ${ }^{25}$

Lai Lielbritānijas flotē brauktu par kapteini, vismaz noteiktos laikposmos bija jābūt ne tikai pilsonim, bet arī dzimušam Lielbritānijā. ${ }^{26}$ 1946. gada sākumā vairāki latviešu tālbraucēji kapteiṇi, kas tobrīd mita pārvietoto personu nometnē britu joslā Vācijā, nolēma, ka vislabākais veids, kā legāli turpināt braukt jūrā visaugstākajā rangā, būtu mēgeināt iegūt kapteiņa vietu uz Kinnas tirdzniecības flotes kuǵiem. Darbs šîs valsts flotē un pašas flotes liktenis latviešu kaptein,iem tobrīd škita gana perspektīvs: tādu priekšstatu bija radijjušas ziṇas par Kīnas iespējām pārṇemt daḷu Japānas tirdzniecības flotes un par gaidāmo straujo flotes attīstību, kas kāpināšot pieprasījumu pēc attiecīgās jomas speciālistiem. "Latviešu jūrnieki uz K̦īnas kuǵiem ir jau braukuši un viniem ir laba slava Ķīnā," par latviešu izredzēm iekḷūt šajā sektorā optimistisks likās kapteinis Heinrihs Liberts, tomēr lūgdams Latvijas sūtniecības Vašingtonā atbalstu un padomu šai lietā. ${ }^{27}$ Praksē gan izrādījās, ka izdevīgāk ir braukt uz citu valstu, piemēram, Panamas, kug̣iem. Turklāt H. Liberta gadījumā tika piel̦auta arī atkāpe no likuma par kapteiņa Lielbritānijas izcelsmi: 1946.-1947. gadā viņš bija kapteinis uz tobrīd jau britu valdības pārṇemtā Latvijas kug̣a "Kaupo". ${ }^{28}$ Līdzīga veiksme uzsmaidīja arī kapteinim K. R. Slejam, kuram izveidojās laba sadarbība ar Vācijas bēgḷu zonas britu joslas pārvaldi: arī viņš kug̣a vadoṇa gaitas uz Lielbritānijas kuǵiem sāka jau 1947. gadā. $^{29}$ Turklāt, pateicoties tam, ka britu dienestā peldēja ne viens vien bijušais Latvijas kugis un ka šiem peldlīdzekḷiem kaut formāli bija saglabātas "latviskās" īpašumtiesības, ${ }^{30}$ K. R. Sleja un H. Liberts nebūt nebija vienīgie šādi veiksminieki: tā 1949. gadā rudenī Rietumu jūrās zem britu karoga brauca pavisam astoṇi bijušie Latvijas tvaikoṇi ar latviešu cilmes kapteiniem priekšgalā. ${ }^{31}$ Jau tad, kad Otrā pasaules kara gados briti pārṇēma vairākus Latvijas kug̛us, vairāki latviešu kapteiṇi tā arī palika uz pārṇemto peldlīdzekḷu kapteiṇtiltiņa, un vinus par kapteina amatam gana prasmīgiem un uzticamiem atzina Lielbritānijas Kug̣niecības federācija (Shipping Federation). ${ }^{32}$ 
Tik strikta valsts nostāja pilsonības lietās kā Lielbritānijā nebija vērojama pilnīgi visur (vismaz ne pastāvīgi). 40. gadu pirmajā pusē Zviedrijā, lai iegūtu ațauju darbam uz jūras, pietika ar ārzemnieka bezvalstnieka pasi, un, tā kā Zviedrijā tobrīd tika atzīti arī ārvalstu diplomi, tad šie ārvalstu jūrnieki bez pastāvīgas pilsonības varēja ieñemt amatus arī kuǵa virsniecībā, ne tikai apkalpes "lejasgalā". ${ }^{33}$ Pēckara situācijai, kad no Austrumeiropas izplūda bēglu straume, gan bija savas nianses, un, kā jau minēts, arī Zviedrijas varas iestādes pēc kara prasīja jūrniekiem noteiktus pašu valstī iegūtus sertifikātus. Lai arī Hāgas konvencijā tika paredzēts, ka bēgḷi un pārvietotās personas būtu jāpieñem dienestā uz patvērumu sniegušās valsts kuǵa pat bez mītnes zemes pilsonības, ${ }^{34}$ praksē tas ne vienmēr strādāja, pateicoties vietējo arodbiedrību protestiem, kādi redzami minētajā piemērā ar Norvēgiju un tās pavalstnieku saimnieciskajām interesēm. Izteikti negatīvi pret nepilsoṇiem uz kuğa jebkādā profesionālajā rangā izturējusies, piemēram, Francijas valdība. ${ }^{35}$

\section{Uz "apsolīto zemi"! Vai vilka nagos, no lāča bēgot?}

Formalitātes pilsonības un imigrācijas dokumentu kārtošanā Eiropā (precīzāk, ziņas par to, ka citur formalitāšu varētu būt mazāk vai tās būtu vieglāk pārvaramas), kā arī daudzu latviešu bailes no Eiropai draudošajām komunisma briesmām jeb "sarkanā sloga uzvelšanās" Eiropai 50. gadu sākumā veicināja latviešu jūrnieku izceḷošanu uz mītnes zemēm ārpus Eiropas - to noteica Lielbritānijas un citu Eiropas valstu gḷēvā politika un Padomju Savienības tīri geogrāfiskais tuvums ${ }^{36}$ (nozares problēmu dēl atsevišḳās valstīs (piemēram, Lielbritānijā) izceḷoja arī vietējo pilsonību jūrnieki, rādot sava veida priekšzīmi latviešiem). ${ }^{37}$ Kā jau pieminēts, par īstu "apsolīto zemi", kā to mazliet ironiski mēdza dēvēt paši latvieši, 40. gadu otrajā pusē kḷuva ASV. Eiropā palikušos latviešu jūrniekus uz ASV vilināja ne tikai darba meklējumiem vismaz šḳietami labvēlīgākā likumdošana un tālums no Padomju Savienības - gan idejiskā, gan geogrāfiskā ziṇā. Pirmkārt, daudzsološa varēja šḳist arī ASV straujā saimnieciskā izaugsme un tajā pašā laikā jūrnieku trūkums (vai vismaz baumas par to). ${ }^{38}$ Tā kā Amerika karā bija cietusi mazāk nekā daudzas Eiropas valstis, bet jūrnieku, domājams, patiešām trūka, tad uzreiz pēc kara (faktiski jau kara nogalē) latviešu jūrnieks varēja cerēt uz veiksmīgu iekḷaušanos šîs valsts tautsaimniecībā. Otrkārt, Otrā pasaules kara gados izcili slavena visas pasaules latviešu vidū bija kḷuvusi Latvijas sūtniecība Vašingtonā kā ar saviem centieniem saglabāt Latvijas kuǵus, tā aizrautīgo palīdzību jūrniekiem plašajā pasaulē; ${ }^{39}$ tas bija zināms pretmets tām iekšējām nekārtībām, kuras latviešu jūrnieku un kug̣īpašnieku lietās norisinājās, piemēram, Latviešu palīdzības komitejā Zviedrijā. ${ }^{40}$

\begin{abstract}
"Jāsaka, ka nav [...] viegli [...] atrasties Eiropā, jo šeit gandriz nav neviena, kas nevēlētos šo kontinentu atstāt, un man nākas atbildēt uz neskaitāmiem jautājumiem, lai apmierinātu visus interesentus. Domāju, $k a$ bez pārspīlējuma varu teikt, ka šobrīd mūsu aprindās Jūsu vārdam ir vislielākā autoritāte un ka laba daḷa nākotnes cerību, ja tām kādreiz būtu lemts piepildìties, sakoncentrējas ap Jūsu personu," ${ }^{41}$
\end{abstract}

vēstulē Latvijas sūtnim Vašingtonā Alfrēdam Bīlmanim 1946. gadā neviltoti glaimoja latviešu jurists un Latvijas kug̣īpašnieku aizstāvis Georgs Dancigers, atklājot Eiropā mìtošo tautiešu noskaņojumu. Ne mazāka pateicība par A. Bīlmaņa un visas sūtniecības veikumu, toties mazliet lielāka 
skepse par ASV kā "apsolīto zemi” jūtama kāda jūrnieka mātes vēstulē Latvijas sūtniecības Vašingtonā lietvedim Anatolam Dinbergam, kurā viņa pateicas par palīdzību nelaimē nonākušajam dēlam 1949. gada sākumā:

"varu iedomāties, cik Jums tagad grūti laiki jāpārdzivo un cik daudz ir to, kas gaida un lūdz no Jums palìdzïbas - no "apsolitās zemes" Amerikas, kur nu Jums vienam ${ }^{42}$ ir jārïkojas ar trimdinieku likteñiem. Mums Eiropā caurmērā visiem šksiet, ka pie Jums būtu visvieglāk un labāk dzìvot un strādāt. Protams, ir visur sava garoza, bet [mums par] to netik domāt". ${ }^{43}$

Amerika tomēr nebūt neizrādījās nekāds latviešu jūrnieka rožu dārzs. Pirmkārt, tūlīt pēc kara ASV tirdzniecības flotē brieda tendence nodarbināt vienīgi ASV pavalstniekus: sākotnēji šis princips tika piemērots kuǵu kapteiņiem, vēlāk visiem virsniekiem, bet 50. gadu sākumā jau bija attiecināms arī uz daḷu zemāka ranga jūrnieku. ${ }^{44}$ Otrkārt, tāpat kā Eiropā, arī ASV pilsonības iegūšanai bija vajadzīgi pieci gadi, ko jūrniekam visizdevīgāk bija nokalpot uz ASV kugiem, ja kāda no vietējām rēderejām ārzemnieku ņēma pretī tikai ar sākotnējiem vai nepilnīgiem iecel̦ošanas dokumentiem (arī bez imigrācijas kvotas vīzas). ${ }^{45}$

Kopumā ASV izcēlās ar sevišķi stingru imigrācijas politiku, kas laika gaitā palika aizvien stingrāka. 1952. gada 27. jūnijā ASV valdība, baidoties par to, ka valsts varas struktūrās specdienestu darbības ceḷā varētu pieaugt padomju varas ietekme, pieñēma grozījumus imigrācijas un pilsonības likumā - tā dēvēto Makerana-Valtera aktu (McCarran-Walter Act), ${ }^{46}$ kas tā brīža redakcijā bija spēkā līdz 1965. gadam un aukstā kara kārtējā saspīlējuma gaisotnē stingri uzmanijja katru svešinieku, kam teorētiski varētu būt kaut netieša un attāla saikne ar padomju varas struktūrām. ${ }^{47}$ Tādējādi ārvalstu jūrnieks vairs nevarēja vienkārši nokāpt krastā no ASV iebraukuša kug̣a uz likumā paredzētajām 29 dienām, uzrādot vien personas dokumentu vai kādu īslaicīgas ieceḷošanas dokumentu, kā bija līdz šim: tagad katrs jūrnieks tika pakḷauts izmeklēšanai. Latviešu jūrniekam bez pilsonības, kas iegūta kādā no mītnes zemēm, tas nereti beidzās ar arestu un izkāpšanas aizliegumu, ${ }^{48}$ jo attiecībā uz Latvijas Republikas pilsoniem šāda izmeklēšana daudzos gadījumos bija ārkārtīgi apgrūtināta: proti, tā saistījās ar ziṇu ievākšanu no personas pēdējām pastāvīgajām dzīvesvietām, bet pēckara periodā "brīvajā pasaulē" palikušajiem latviešiem, kā zināms, tā parasti bija Eiropa (Vācija, Zviedrija u. c.); vēl sliktāk, ja par pēdējo pastāvīgo dzīvesvietu uz sauszemes bija uzskatāma Latvija, jo ASV imigrācijas iestāžu komunikācija ar attiecīgajām padomju institūcijām varēja būt visai sarežğīta... Cerīgākā latviešu jūrnieka izeja no šādas situācijas bija pagaidu uzturēšanās vīzas (non-imigrant visa) izṇemšana kādā ASV pārstāvniecībā citviet pasaulē, kas vismaz noteiktā laika posmā garantēja jūrnieka izlaišanu Amerikas krastos. Tiesa, arī šādas vīzas izsniegšana varēja ievilkties vai pat nonākt strupceḷā ziṇu ievākšanas apgrūtinājumu dēḷ. ${ }^{49}$

Likumiski apgrūtinātas gan brīvprātīgā, gan iesaukšanas kārtā latviešu bēglim visā trimdas periodā bija arī iespējas dienēt ASV karaflotē, kur uzṇēma tikai pilntiesīgus pavalstniekus (arī karalaikā). ${ }^{50}$ Tos, kas nebija uzsākuši ASV pilsonības kārtošanas procedūru, armijas lietas neskāra un iesaukums neapdraudēja (autora rīcībā nav ziṇu par brīvprātīgajiem), bet ASV pavalstniekam pēc iesaukšanas parasti bija iespēja izvēlēties - dienēt sauszemes, gaisa (aviācijā) vai jūras spēkos (kara flotē). Toties pavisam neērtā situācijā atradās tie iesaucamā vecuma latviešu vīieši ASV, kas izteikuši vēlmi pēc šīs valsts pilsonības, 
bet tās iegūšanu nebija nokārtojuši līdz galam, - tādā gadījumā uz viniiem attiecās iesaukums un karadienests, bet kā politiski tomēr ne gana uzticamiem viniem nebija iespēju izvēlēties dienēt ārpus sauszemes spēkiem. ${ }^{51}$

Vēl pētāms ir jautājums, kādas imigrācijas normas tika piemērotas tiem 1940. gadā ASV palikušo astoṇu kuǵu jūrniekiem, kas kolektīvā veidā - ar visiem kug̣iem un apkalpēm - nonāca ASV dienestā un to turpināja arī pēc kara beigām; vai tika piemērots pārvietotās personas statuss; cik îsā laikā obligāti bija jāuzsāk pilsonības iegūšanas process, kas neapšaubāmi bija nepieciešams ikvienam (protams, ne tikai jūrniekam), kurš ASV vēlējās dzīvot un strādāt pastāvīgi. Pēc atseviškiem avotiem, iespējams piel̦aut, ka šo jūrnieku dzīvi un uzturēšanos ASV kardināli ietekmēja izmaiņas ASV imigrācijas un pilsonības lietu likumdošanā 1952. gada vasarā. Tā vedina domāt kopš karalaika ASV kuǵojošā un N̦ujorkā pastāvīgi mītošā latviešu jūrnieka Pētera Kaņepa vēstule Latvijas sūtniecībai Vašingtonā 1953. gada janvārī, kurā viņš žēlojas, ka negaidīti, nokāpjot no kuğa pēc kārtējā brauciena, saṇēmis ASV imigrācijas dienestu pavēsti, ka turpmāk viņš valstī drīkstot uzturēties vien kā ārzemju jūrnieks likumā noteiktās 29 dienas, citādi tikšot deportēts. ${ }^{52}$ Jūrnieka specifika attiecībā uz imigrācijas dienestiem bija tāda, ka jūrnieks ir atkarīgs no kuǵu atiešanas un pienākšanas laikiem, ko bieži bija teju neiespējami saskaņot ar dažādu formalitāšu nokārtošanas tempiem un terminiem imigrācijas iestādēs.

Pret tiem, kas ASV bija iecelıši nelegāli (bez ieceḷošanas atḷaujas vai pat bez personas dokumentiem), šîs valsts likumi bija sevišķi bargi, un pats nepatīkamākais, kas varēja sagaidīt latviešu jūrnieku bez legālas uzturēšanās ațlaujas, bija jau iepriekš minētā piespiedu izsūtīšana jeb deportācija, un šādā gadījumā pastāvēja divi galvenie scenāriji: palikšana "brīvajā pasaulē" darbā uz kāda kuǵa vai nonākšana atpakal, okupētajā Latvijā. Latvijas pārstāvniecības iespēju robežās centās atsaukties uz jūrniekiem, kuri bija nonākuši šādā situācijā un citās līdzīgās grūtībās, vajadzības gadījumā sagādājot viniem kaut pagaidu personas dokumentus; ${ }^{53}$ savu artavu sniedza arī dažās pilsētās izvietotās latviešu palīdzības organizācijas. Nelegālie iebraucēji ASV bieži tika novietoti vai nu kādā cietumā, vai Elisa salā (Ellis Island) N̦ujorkā - tā dēvētajā imigrācijas karantīnā jeb pagaidu nomitinājumā; tālākais nomitinātā liktenis parasti bija atkarīgs no ASV Tieslietu ministrijas (Attorney General) ${ }^{54}$ imigrācijas komisāra Vašingtonā lēmuma. ${ }^{55}$ Otra izeja bija imigranta pieņemšana darbā uz kug̣a kādā vietējā jūrniecības kompānijā: būdams oficiāli nodarbināts, imigrants varēja puslīdz legāli atstāt ASV ${ }^{56}$ un jūrasbrauciena laikā, ja bija vēlme "apsolītajā zemē" nomitināties, iegūt no kādas citā valstī esošas ASV pārstāvniecības likumīgu ieceḷošanas atḷauju ${ }^{57}$ - protams, ja vien ASV imigrācijas dienesti izsniedza atḷauju imigrantam kā jūrniekam uz kāda kuǵa no valsts izbraukt. Taču šādus "nelegālus" (un, iespējams, ārzemniekus vispār) amerikāṇu kug̣niecības kompānijas uzṇēma nelabprāt. ${ }^{58}$

Latviešu jūrnieku nedienas ar dažādu valstu imigrācijas dienestiem visā pasaulē daḷēji atviegloja 1954. gadā pieņemtā Hāgas konvencija, kas bija attiecināma uz bezvalstniekiem - tātad arī jūrniekiem, kuriem konvencijā veltīts atsevišks paragrāfs. Tas paredzēja, ka jūrnieks darbā uz kādas konvenciju parakstījušās valsts kuǵa varēja tikt pieñemts arī bez konkrētas valsts pilsonības un pastāvīgas dzīvesvietas - pietika tikai ar attiecīgās valsts izsniegtu rakstisku apliecinājumu, ka tā sniegusi jūrniekam pagaidu patvērumu. ${ }^{59}$ Citos gadījumos līdzēja jūrnieku arodorganizācijas, kurās dažkārt latviešu jūrniekiem izdevās iesaistīties pat 
bez pilnībā sakārtotiem attiecīgās valsts pilsonības dokumentiem. ${ }^{60}$ Daudziem jūrniekiem imigrācijas lietās gan ASV, gan citviet pasaulē sniegusi atbalstu Latvijas sūtniecība Vašingtonā, kas uzturēšanās aț̣aujas un vīzas izgādājusi ne vienam vien latviešu jūrniekam, jādomā - kopumā desmitiem vai pat simtiem jūrnieku. Iespējams, vairāku jūrnieku ieceḷošanu, sākotnējo uzturēšanos un palikšanu ${ }^{61}$ ASV nodrošinājusi arī Grauda rēdereja N̦ujorkā, sagādājot iecelojušajam jūrniekam darbvietu ar iepriekš parakstītu darba līgumu jeb angažejjumu. ${ }^{62}$

Imigrācijas problēmas latviešu jūrniekus pārsteidza arī Dienvidamerikas valstīs. Dažviet, piemēram, Dominikas Republikā, pat īslaicīgas uzturēšanās (iebraukšanas) atḷaujas iegūšanai bija nepieciešams viens vai vairāki galvotāji no valsts pilsoṇiem vai pastāvīgajiem iemītniekiem. ${ }^{63}$ Bet, ja jūrnieks šai valstī nokḷuvis pirmo reizi mūžā un, iespējams, nekad vairs neatgriezīsies, tad kur gan lai atrod šādus galvotājus? Savukārt Venecuēlā, lai uzturēšanās būtu likumīga, vajadzēja vismaz uz gadu noslēgt darba līgumu ar kādu no vietējām firmām, kas arī nebūt nebija vienkārši izdarāms. Citkārt izkāpšanu krastā un uzturēšanās atl̦auju atteica vienkārši tāpat - bez konkrēta paskaidrojuma un atsauces uz likumdošanas pantiem. ${ }^{64}$

Tātad gan Eiropā, gan ārpus tās Amerikas kontinentā - allaž pastāvēja zināmas problēmas kā ar pilsonības ieguvi un imigrācijas dienestiem, tā ar pirmajās pāris pēckara desmitgadēs īpaši uzmācīgo svešinieka statusu kā tādu, kas, kā jau daḷēji pieminēts, varēja saistīties tiklab ar politisko uzticamību un valsts amatpersonu protekcionistisko vēlmi dot saimniecisku priekšroku saviem pilsoniem, gan racionālām bažām - emigrantu tautas nepārbaudītajām darbspējām un citādām mentalitātes īpatnībām, kas potenciāli varēja apgrūtināt sadarbību ar kuǵīpašniekiem un kapteiņiem ar vietējo pilsonību.
"Vienreiz es tiešām dabūju iepazities ar to faktu, ka ir diezgan maz nāciju un vēl mazāk kapteinu, kas [...] vēlas n,emt bēglus uz sava kuǵa. Apmeklēju vairākas ostas un neskaitāmus kuǵus, visur sañemdams negativu atbildi. Ar to ațauju palikt malā arī negāja. Beigās man tikai atlika jautāt, vai nebūtu iespējams uzkāpt uz krievu kuǵa,"

tā savas nedienas pirmajos pēckara gados 1960. gadā atminējās latviešu jūrnieks Zviedrijā Raimonds Mūrnieks (1925-?), piebilstot, ka gadījumi, kad latviešu jūrniekiem kā sveštautiešiem aizliegts izkāpt krastā, dažās zemēs esot sastopami vēl aizvien - tātad 60. gadu sākumā, turklāt trūkstot pārliecības, ka šādi aizliegumi neparādīšoties arī citviet. ${ }^{65}$ Savukārt tāljūras kapteinis Kanādā I. Balodis raksta, ka šis aspekts vēl 50. gadu vidū traucējis kugot pat zema ranga amatā, jo kanādiešu kapteiņi un kug̣īpašnieki svešiniekiem bez pieredzes tieši Kanādas jūrniecības nozarē neuzticējušies un savu kuğu darbiniekus izraudzījušies no personīgi pazīstamo vidus:

"Domāju, ja ne citādi [proti - ja neizdosies dabūt augstāka ranga amatu kāda kuǵa apkalpē - D. B.], dabūšš vietu uz kāda no daudzajiem ezeru kuǵiem. Bet nekā! Izstaigājos pa Toronto un Montreālu, visur prasija "Canadian experience" trešajiem stūrmañiem labāk nemot savus bijušos stūres vïrus, kas jau ko zina par upēm, kanāliem un ezeriem, nekā vienu svešinieku. Daudz gadus vēlāk to labi sapratu." ${ }^{67}$

Turklāt šo situāciju vēl vairāk saasināja nozares darbinieku un to pārstāvošo institūciju iekšējās idejiskās nesaskaņas. "[Pat] par matrozi nevarejju tikt," turpina I. Balodis.

"Arodbiedribas tos, kas braukuši par virsniekiem, neñēma pretim. Tolaik te bija divas savā starpā kaškìigas arodbiedrïbas. Viena 
no tām bija ļoti komunistiski noskan,ota, ${ }^{68}$ otra nē." ${ }^{69}$

Kā to iezīmē jau I. Baloža atmin, as, politiskās problēmas dažkārt saistījās arī ar attieksmi pret pavisam konkrētiem politiskajiem režīmiem, konkrētāk - padomju varu. Šī problēma izpaudās divējādi.

Pirmkārt, strādājot kādas Rietumvalsts tirdzniecības flotē, pastāvēja risks preču pārvadājumu gaitā nonākt kādā padomju varas ietekmes ostā, kur latviešu jūrnieku varētu pārsteigt "plašās Dzimtenes" “draudzīgā" vēlme pēc "Dzimtenes dēla" atgriešanās "mājās". Apzinoties padomju varas represīvo iedabu, baltiešu jūrnieki trimdā to uzskatīja par visai nopietnu problēmu; piemēram, 1962. gadā Igauṇu jūrnieku arodbiedrības darbinieki baltiešu jūrniekus "brīvajā pasaulē" brīdinoši aicināja "nebraukt uz kuǵiem, kas apmeklē padomju ostas", norādot, ka

"Padomju Savienība uzskata katru aizbēgušo par savu pilsoni, kaut arì tas būtu pieñēmis citas valsts pilsonibu. Padomju vara var apcietināt jūrnieku arī tad, ja tas neatstāj ostā savu kug̣i". ${ }^{70}$

Tomēr ne visi par to aizdomājās un ne visiem bija iespējams no šāda riska izvairīties. İpaši satraucoša izvērtusies I. Baloža - tobrīd Kanādas jūrnieka, kas ceḷoja zem Bermudas karoga, - izkāpšana krastā Tuapsē Melnās jūras krastos, tiešā padomju ietekmes sfērā. Latviešu jūrnieks atceras, kā viṇu uzraudzījusi Padomju Savienības specdienestu modrā acs. ${ }^{71}$

Iespējams, no pavisam līdzīgas situācijas vai daudz trağiskāka likteṇa izdevās izvairīties kādam latviešu trimdas jūrniekam, uzvārdā Speks. Viṇš vēl trīs mēnešus pēc kara beigām Latvijā cīnījies t. s. nacionālo partizānu rindās pret padomju okupācijas varu, tad pārbēdzis uz Zviedriju, uzkāpis uz kug̣a, bet vēlāk, kad kuğis saṇēmis rīkojumu doties uz Krieviju, no klāja aizbēdzis, pārlecot pāri bortam Dardaneḷu jūras šaurumā, un vēlāk izpeldējis krastā. ${ }^{72} \mathrm{Nav}$ šaubu, ka bijušajam nacionālajam partizānam ar Zviedrijas pilsonību vai bez tās Padomju Savienībā varēja klāties samērā bēdīgi. Tiesa, lasot gan šo brīdinājumu, gan citētās I. Baloža un līdzīgas atminas, jāatceras, ka trimdinieku uzburtajās pagātnes ainās, tāpat kā trimdas presē, "visvarenās čekas" ietekme un informētība nereti tika vairāk vai mazāk pārspīlēta.

Otrā problēmas šķautne saistījās ar gluži pretējiem valstu politiskajiem uzskatiem un izpaudās kā zināma politiskā diskriminācija un neuzticība, ko raisīja latviešu jūrnieku saistība ar Latviju kā "komunistu valsti”. Ēna, ko latvieša biogrāfijā "brīvajā pasaulē" meta piederība zemei, kas iekḷauta Padomju Savienības sastāvā, izrādījās pietiekami gara, lai - par spīti baltiešu trimdas politiskajām aktivitātēm - raisītu rietumniekos aizdomas par ikviena latvieša piederību komunistiem: latvietis - tātad komunists, komunistiskās Latvijas un komunistu pārstāvis. Politiskās pozīcijas dēl īpaši piesardzīgas pret "komunisma draudiem" un latviešu (baltiešu) jūrniekiem kā "komunisma baciḷa" pārnēsātājiem bija abu Amerikas kontinentu valstis: ASV ostu ierēdṇi vēl 60.-70. gados latviskas izcelsmes jūrniekiem nereti vaicājuši par vinu saistību ar Komunistisko partiju, ${ }^{73}$ bet Dienvidamerikas valstu ierēdṇi greizi raudzījušies uz Latvijas Republikas iestāžu izdotiem personas dokumentiem.

Tuvākai ilustrācijai vispirms aplūkosim divus gadījumus ASV 50. gadu sākumā, kad latviešu jūrnieki Latvijas sūtniecībai Vašingtonā sūdzējušies par to, ka amerikāṇi bez jebkāda pamata viņus uzskatot par komunistiem.

Pirmais gadījums stāsta par kāda latviešu jūrnieka - Ludviga Kiiploka - pēkšn,o atstādināšanu no amata ASV kug̣niecības firmā Isthmian Steamship Company (tvaikonis 
Steel Worker) 1949. gada augustā. Un, lai gan atlaišana notikusi bez jebkādiem paskaidrojumiem, ${ }^{74}$ L. Kiplokam jau uzreiz radušās aizdomas par politiskās neuzticamības apsvērumu:

"Savus pienākumus esmu izpildïjis pēc vislabākās apzinas. Neesmu sastāvējis nekādās politiskās, nedz sabiedriskās organizācijās, ne Latvijā, nedz arī šeit. Neesmu piedalïjies nekādās sapulcēs, gājienos, nedz arī pat runājis par politiskām lietām jeb uzskatiem. Esmu vienmēr lojāls bijis pret $S$ [avienoto] $V$ [alstu] valdïbu un pilsoniem. [...] Vai tiešām Latvijas jūrniekiem, latviešiem neațlaus braukt uz S[avienoto] V[alstu] kuǵiem? Es jūtos l̦oti dzilı sāpināts, un apvainojums par manu uzticigo kalpošanu arī skar materiālo pusi. Man ir jāuztur nespēciga sievas māte, kura ar 1. augustu iebrauca no Vācijas uz dzīvi $S$ [avienotajās] V[alstīs], savā 84 gadu vecumā,"

tā aizvainojumu politiski jūtīgajos jautājumos un situācijas smagās sekas Latvijas diplomātiem atklāj L. K,iploks, ${ }^{75}$ citviet kā, viņaprāt, garantiju politiskajai uzticamībai uzsvērdams arī dalību Otrajā pasaules karā Rietumu sabiedroto pusē: "Visu kara laiku esmu aktivi piedalïjies, pat savu kārtējo atvalinājumu neesmu dabūjis, un mēs vienmēr tiekam aizmirsti." ${ }^{76}$ L. Kiiplokam tika piemērota ne vien atlaišana no konkrētās vietas, bet arī aizliegums strādāt uz ASV tirdzniecības kuǵiem vispār; lietas gaitā patiesi izrādījās, ka tas saistīts ar zināmu "drošỉbas risku" (security risk), tiesa, bez konkrēta paskaidrojuma par šì tā dēvētā riska politisko kontekstu. ${ }^{77}$ Tikai pēc gada, 1950. gada 12. septembrī, pateicoties paša jūrnieka neatlaidībai un Latvijas sūtniecības atbalstam personas dokumentu piesūtīšanā, process tika izbeigts un L. Kiploks no ASV varas iestādēm san̄ēma apliecinājumu, ka lieta ir izbeigta un jūrnieks atkal drīkst kugóot uz ASV tirdzniecības kugiem. ${ }^{78}$
Otrais gadījums saistās ar latviešu jūrnieka Boḷeslava Senkeviča sašutumu un aizvainojumu par 1952. gadā pieņemto t. s. Makerana-Valtera aktu, kas, kā jau minēts, paredzēja papildu ierobežojumus ārvalstu jūrnieku izkāpšanai krastā ASV ostās, pakḷaujot jūrniekus aizturēšanai un izmeklēšanai tieši ar padomju varu saistītu aizdomu kontekstā. Precīzāk - B. Senkevičs, kurš cieta no jaunā likuma un gada beigās tika uz kuğa apcietināts, jutās teju personīgi apvainots un apsūdzēts komunistiskā diversijā:

"L̦oti sāpigi dzirdèt par jauno Mac Carran likumu, kurš izdomāts $S$ [avienoto] V[alstu] iekšējai drošǐbai; [tas] ir izdarījis lielu netaisnïbu Latviešu tautibas jūrniekiem, kuri ir nodarbināti uz dažādas tautības kuǵiem un [kuriem] pa daļai nav noteiktas uzturēšanās vietas. [...] Iznāk, ka Latviešu jūrnieki ir komunisti vai tā piekritēji, vai citāda veida nedrošas personas. Es nezinu, vai tiešām atradisim daudz starp mūsu tautibas [jūrniekiem], kuri simpatizètu komunismam, kurš ir izdarïjis tik daudz l,auna mums." ${ }^{79}$

Nevienā no abiem minētajiem gadījumiem jūrniekiem nav bijis konkrētu faktu, kas apstiprinātu viṇu politisko diskrimināciju, proti, viṇu un Latvijas saistību ar komunistisko režìmu, - vien aizdomas un netiešas norādes; taču tas pats nav sakāms par latviešu jūrnieku piedzivojumiem Dienvidamerikas valstīs. Īpaši bēdīgi latviešu jūrniekiem klājies Brazilijā, ${ }^{80} \mathrm{Kubāa}^{81}$ un Dominikānā, kur varas iestādes nav gribējušas izsniegt ieceḷošanas vīzu Latvijas Republikas pases īpašniekiem un aizliegušas jūrniekiem izkāpt krastā. Piemēram, Dominikānas galvaspilsētā Santodomingo latviešu jūrnieka I. Baloža izkāpšanu krastā kavēja vietējo varas iestāžu pārmetumi par to, ka jūrnieks "dzimis komunistu zemē", tātad a priori ir neuzticams un bīstams (pats I. Balodis gan to skaidro ar čekas 
ietekmi un Padomju Savienības centieniem "sagrābt" okupēto valstu bijušos pilsoṇus jeb, kā rakstīja pats kapteinis, vēlmi vinuus sagrābt "ar garo komunistu roku"). ${ }^{82}$ "Citudad Trujillo [Dominikānā] [...] mani uzskata par pilsoni aiz dzelzs priekškara," 83 neizpratnē par Dominikānas valdības rīcību 1954. gadā bija cits latviešu kapteinis Kārlis Kirmuška (1907-1994), augsta ranga darbinieks uz Kanādas kompāniju kuǵiem. Nedēḷu vēlāk kaut ko līdzīgu piedzīvojis arī Kubā, kapteinis, liekas, jau kḷuva pilnībā pārliecināts, ka pret viṇu vērstas aizdomas kā pret komunistu, uzsverot, ka pirms kara un pašos pirmajos pēckara gados šāda parādība nav piedzīvota:

“Kopš 1932. g. un arī pēc kara esmu vairākas reizes bijis Cubā, bet [...] grūtïbas netiku piedzivojis." 84

Latviešu jūrnieka vienīgā cerība šādā situācijā bija zibenīga Latvijas diplomātisko pārstāvniecību reakcija, ilgtermiņā - pases un pilsonības maiña, izraugoties politiski "drošāku” jeb neitrālāku valsti. Ciktāl tas attiecas uz kapteiņa K. Kirmuškas izkāpšanu Dominikānā, ${ }^{85}$ Latvijas diplomātisko dienestu iejaukšanās gan, visticamāk, nozīmēja arī ilgtermiṇa risinājumu, ${ }^{86}$ taču pilnībā paḷauties uz to nevarēja. Turklāt, pat ja ieceḷošana Dienvidamerikas valstīs, teiksim, ar Latvijas diplomātisko pārstāvniecību pūlēm, kādam latviešu jūrniekam izdevās, šie dokumenti paši par sevi sniedza vien formālas garantijas: ja kāda imigrācijas ierēdṇa galvā dzima aizdomas, ka uzturēšanās dokuments iegūts ar nodomu vēlāk no kuǵa slepus nokāpt un palikt malā kā nelegālajam imigrantam (un/vai padomju aǵentam ar uzdevumu), atkal varēja rasties problēmas. ${ }^{87}$ Šādas varas struktūru aizdomas parasti vajāja tos jūrniekus, kas it kā nebija izrādījuši pietiekamu interesi sakārtot pastāvīgās dzīvesvietas problēmu, un pat Latvijas pārstāvniecības šādā gadījumā ne vienmēr varēja līdzēt. ${ }^{88}$ Tiesa gan, kā noprotams pēc K. Kirmuškas sarakstes ar Latvijas sūtniecību Vašingtonā 1955. gadā, šādi gadījumi tomēr bijuši drīzāk izṇēmums, turklāt jūrniekos valdījušas cerības, ka nākotnē nejaukā parādība pamazām izplēnēs. ${ }^{89}$

(Noslēgums nākamajā numurā.)

\section{ATSAUCES UN SKAIDROJUMI}

${ }^{1}$ Sk.: DĀVIS BEITLERS. Latvijas jūrnieku ceḷi trimdā: izklīšanas veidi, cēloṇi, motīvi. In: Latvijas Universitātes Žurnāls. Vēsture 2019, Nr. 7/8, 87.-102. lpp.

${ }^{2}$ Igaun u jūrnieku... In: Latvju Ziņas, 05.07.1945., 2. lpp.

${ }^{3}$ Latviešu jūrniekiem... In: Latvju Ziņas, 25.08.1945., 2. lpp.

${ }^{4}$ Gēteborgas jūrskolu... In: Latvju Ziṇas, 15.06.1950., 6. lpp.

${ }^{5}$ Ibidem.

${ }^{6}$ F. Flensburgas baltiešu DP jūrskolas... In: Tēvzeme, 23.11.1946., 3. lpp.

${ }^{7}$ Darbojās no 1945. līdz 1950. gadam, latviešu bēgḷu aprūpē iesaistījās 1946. gadā, nostājoties līdzās Apvienoto Nāciju Palīdzības un atjaunošanas pārvaldei (United Nations Relief and Rehabilitation Administration) šajā darbības jomā.

${ }^{8}$ Presē ir ziṇas, ka kugois ticis nodots tiešā IRO rīcībā. Sk.: Latvieši pasaulē. In: Austrālijas Latvietis, 22.05.1949., 5. lpp.; Kapt[einis] PAUlS NeIMANis. Norvēgéi negribēja latviešus. In: Latvija, 15.07.1949., 2. lpp.

${ }^{9}$ NEIMANIS, Norvēǵi negribēja latviešus. 
${ }^{10}$ Sk.: Latvieši pasaulē.

${ }^{11}$ NeIMANIS, Norvēǵi negribēja latviešus.

12 O[L̦EGS] GoNČAROvs. Patiesība par jūrniekiem. In: Latvija, 28.05.1949., 2. lpp.

${ }^{13}$ Vācijā atrodas 24.000 leǵionāru. In: Latvju Vārds, 12.09.1945., 4. lpp.

${ }^{14}$ Latvieši Vestergetlandē. In: Latvju Vārds, 05.09.1945., 4. lpp.

${ }^{15}$ J. Vārsberga vēstule Latvijas sūtnim Vašingtonā Alfrēdam Bīlmanim, Stokholma, 06.09.1948. Latvijas Nacionālais arhīvs, Latvijas Valsts vēstures arhīvs, Rīga (turpmāk - LNA LVVA), 293-1-4048, 40. lp.

${ }^{16}$ Ibidem, 38. lp.

${ }^{17}$ Piemēram, Dānijā palikušais Padomju Savienībai izdotā motorkuǵa "Bru" kapteinis Kārlis Vētra (1908-?) pēc 1946. gada turpināja braukt par trešo stūrmani uz dāṇu tirdzniecības kug̣a Blekinge. Sk.: K. Vētras vēstule A. Bīlmanim, 12.09.1947. Ibidem, 293-1-1943, 21. lp.

${ }^{18}$ V. O. "Latvji, brauciet jūriņā...": kā amerikanizējies latviešu rēderis piemānīja mūsu jūrniekus. In: Latvija, 17.12.1949., 2. lpp.

${ }^{19}$ A. Bīlmaņa vēstule jūrniekam K. Vētram Dānijā, 17.09.1947. LNA LVVA, 293-1-1943, 20. lp.

${ }^{20}$ Saskan̄ā ar 1948. gada ASV imigrācijas likumu pārvietotās personas statuss tika definēts šādi: bēglis, kas 1947. gada 22. decembrī atradies amerikāṇu, angḷu un franču okupācijas joslās Vācijā, Austrijā un Itālijā. Sk. arī: Latvijas sūtniecības Vašingtonā 1. sekretāra Anatola Dinberga vēstule jūrnieka Gvido Alkšņa mātei Paulīnei Alksnei, 26.08.1949. Ibidem, 72. lp.

${ }^{21}$ A. Dinberga vēstule jūrniekam Ludvigam K,iplokam, 19.10.1948. Ibidem, 107. lp.

${ }^{22}$ V. O. "Latvji, brauciet jūriņā...".

${ }^{23}$ Autora saruna ar Ritu Jefimovu Rīgas vēstures un kuǵniecības muzejā 27.10.2020.

${ }^{24}$ IMANTS BALODIs. Dažādās vietās un laikos. [Autobiogrāfijas manuskripts datorrakstā.] 20. gs. 90. gadi, 9. lp.

${ }^{25}$ Jāṇa Hartmaṇa apkopotas ziṇas par Ādolfu Ceḷdomu, 13.04.1999. [Mašīnraksts.] Rīgas vēstures un kuğniecības muzeja Latvijas kuǵniecības vēstures nodaḷa (turpmāk - RVKM LKVN), personas kartïte "Ādolfs Cel̦doma".

${ }^{26}$ Kapteiņa Heinriha Liberta vēstule A. Bīlmanim. Ķīle, 01.02.1946. LNA LVVA, 293-1-1943, 3. lp.

${ }^{27}$ Ibidem.

${ }^{28}$ JĀNIS HARTMANIS. [Šķirklis par kapteini H. Libertu.] In: IlzE BERnsone (galv. red.). Latvijas jūrniecības vēsture 1850-1950. Rīga 1998, 90. lpp.

${ }^{29}$ Kapt[einis] A[RVALDS] M[ĀRTIN̦Š] KALNin̦š. Mūžǐbas jūru ceḷos [Krišjāṇa Rūdolfa Slejas nekrologs]. In: Laiks, 07.09.1994., 7. lpp.

${ }^{30}$ Tuvāk sk., piem.: DĀVIS BEITLERS. Latvijas kug̣i un jūrnieki Rietumvalstīs varu krustpunktos: latviešu jūrniecība trimdā 1940.-1948. gadā. In: Vēstures lūzumpunkti un robežškirtnes arhīvu dokumentos. Latvijas Valsts vēstures arhīva zinātniskie lasījumi: IV. [Rīga] 2018, 183.-186. lpp.

${ }^{31}$ VDN. Pasaules jūrās vēl brauc 10 Latvijas kuguu. In: Latvija, 19.10.1949., 2. lpp.

${ }^{32}$ Sk., piem., tvaikoṇa "Elizabete" kādreizējā stūrmaṇa Jāņa Rūdolfa Freimaņa (1911-1990) nedatētas atmiņas "Latviešu tvaikoṇa "Elizabete" kara gaitas", 6. lp. [Rokraksta kserokopija.] RVKM LKVN, zinātniskais arhīvs, LJVA Ja 6, 107. lp.

${ }^{33}$ Latvijas tvaikoṇa "Vizma" bijušā kapteiṇa Paula Skultes (1898-1990) vēstule Latvijas pilnvarotajam ministram Zviedrijā Voldemāram Salnajam. Gēteborga, 14.10.1940. LNA LVVA, 293-2-135, 1. 1p.

${ }^{34}$ Jūrnieka Raimonda Mūrnieka (1925-?) vēstule A. Bīlmanim, 01.09.1960. Ibidem, 2931-1946, 4. lp.; sk. arī 1954. gadā Hāgā pieņemto Konvenciju par bezvalstnieka statusu (Convention relating to the Status of Stateless Persons). Pieejams: http://www.unhcr.org/ibelong/ 
wp-content/uploads/1954-Convention-relating-to-the-Status-of-Stateless-Persons_ENG.pdf (skatìts 12.10.2020.).

${ }^{35}$ R. Mūrnieka vēstule A. Bīlmanim, 01.09.1960. LNA LVVA, 293-1-1946, 4. lp.

${ }^{36}$ Sk., piem.: profesora Friča Gulbja vēstule Latvijas sūtnim Vašingtonā Jūlijam Feldmanam. Hamiltona, 31.01.1951. Ibidem, 293-1-1454, 176. lpp.

${ }^{37}$ BALODIs, Dažādās vietās un laikos, 9. lp.

38 Jūrnieka Alberta Eina vēstule A. Bīlmanim, 28.02.1945. LNA LVVA, 293-1-1943, 5. lp.

${ }^{39}$ Par to liecina jūrnieku vēstules sūtniecībai no visas pasaules. Sk., piem.: ibidem, 293-1-1943-1946.

${ }^{40}$ Kug̣īipašnieka un kug̣niecības sabiedriskā darbinieka Jāṇa Zalcmaņa (1887-1971) vēstule A. Bīlmanim. N,ujorka, 27.09.1946. Ibidem, 293-1-1931, 22. lp.

${ }^{41}$ G. Dancigera vēstule A. Bīlmanim. Stokholma, 22.07.1946. Ibidem, 293-1-1898, 28.-29. lp.

42 Tobrīd A. Dinbergs bija pārṇēmis sūtniecības lietas no tikko mūžībā aizgājušā sūtņa A. Bīlmaņa.

${ }^{43}$ P. Alksnes vēstule A. Dinbergam, 14.02.1949. LNA LVVA, 293-1-1943, 49. 1p. Citā - 07.03.1949. vēstulē (ibidem, 51. lp.) P. Alksne A. Dinbergam neslēpj: "Jūs nu esiet vistuvākā valdǐšana puikam no latviešu puses."

${ }^{44}$ A. Dinberga vēstule L. Ķiplokam, 31.08.1950. Ibidem, 105. lp.

45 J. Feldmana vēstule G. Alksnim, 23.08.1949. Ibidem, 71. lp.

${ }^{46}$ Oficiāli - Immigration and Nationality Act of 1952.

47 MARION T. BENNETT. The immigration and nationality (McCarran-Walter) Act of 1952, as Amended to 1965. In: The Annals of the American Academy of Political and Social Science 367, 1966, 1, pp. 127-136.

${ }^{48}$ B. Senkeviča vēstule Latvijas sūtniecībai Vašingtonā. Portlenda, 01.01.1953. LNA LVVA, 293-1-1943, 115. lp.

${ }^{49}$ A. Dinberga vēstule jūrniekam B. Senkevičam, 07.01.1953. Ibidem, 114. lp.

${ }^{50}$ A. Eina vēstule A. Bīlmanim, 28.02.1945. Ibidem, 4. lp.

${ }^{51}$ Amerikas Latviešu Apvienības kongresa Rezolūcija par latviešu iestāšanos ASV bruṇotajos spēkos, 23.08.1952. Ibidem, 293-1-1331, 17. lp.

52 P. Kaṇepa vēstule Latvijas sūtniecībai Vašingtonā, 10.01.1953. Ibidem, 293-1-1943, 117. lp.

${ }^{53}$ Sk., piem.: A. Dinberga vēstule P. Alksnei, 29.12.1948. Ibidem, 39. lp.

${ }^{54}$ A. Dinberga vēstule P. Alksnei, 31.01.1949. Ibidem, 46. lp.

${ }^{55}$ A. Dinberga vēstule P. Alksnei, 26.08.1949. Ibidem, 72. lp.

${ }^{56}$ P. Alksnes vēstule P. Dinbergam par to, ka viņas dēls G. Alksnis saṇēmis "caur Standart Oil Co. jūrnieka papīrus". Ibidem, 49. lp.; A. Dinberga vēstule P. Alksnei, 16.02.1949. Ibidem, 50. lp.

${ }^{57}$ P. Alksnes vēstule A. Dinbergam, 07.03.1949. Ibidem, 51. lp.; J. Feldmana vēstule G. Alksnim, 23.08.1949. Ibidem, 71. 1p.

${ }^{58}$ Sk.: G. Alkšņa vēstule J. Feldmanam, 19.08.1949. Ibidem, 64. lp.

${ }^{59}$ Hāgas konvencija "Par bezvalstnieka statusu" (Convention relating to the Status of Stateless Persons).

${ }^{60}$ Šādi notika, piemēram, ar minēto latviešu jūrnieku P. Kaṇepu ASV, kurš bija vietējās jūrnieku arodbiedrības biedrs, baudīdams pārvietotās personas statusa priekšrocības. Sk.: A. Dinberga vēstule P. Kaņepam, 23.01.1953. LNA LVVA, 293-1-1943, 116. lp.

${ }^{61}$ ARvis POPE. [Šḳirklis par kapteini Pēteri Līci.] In: BERNSONE, Latvijas jūrniecības vēsture 18501950, 91. lp.

${ }^{62}$ A. Dinberga vēstule jūrniekam P. Līcim, 06.01.1948. LNA LVVA, 293-1-1943, 22. lp.

${ }^{63}$ Šādā situācijā bija nokḷuvis latviešu jūrnieks R. Mūrnieks 1960. gada septembrī-oktobrī, uzturoties Dominikā: tās imigrācijas dienesti uzstāja, ka jūrniekam nepieciešama uzturēšanās atḷauja, un 
šim nolūkam pieprasīja uzdot divus galvotājus. Sk.: R. Mūrnieka vēstule Latvijas sūtniecībai Vašingtonā. Port Alfred, 14.10.1960. Ibidem, 293-1-1946, 10. lp.

${ }^{64}$ R. Mūrnieka vēstule Latvijas sūtniecībai Vašingtonā, 21.11.1960. Ibidem, 24. lp.

${ }^{65}$ R. Mūrnieka vēstule Latvijas sūtniecībai Vašingtonā, 01.09.1960. Ibidem, 6. lp.

66 "Kanādas/kanādiešu pieredze" (angḷu val.).

${ }^{67}$ BALODIS, Dažādās vietās un laikos, 9. lp.

${ }^{68}$ I. Balodis savās atmiņās gan nenorāda, vai konkrētā arodbiedrību attieksme pret komunistisko režīmu kaut kādā veidā ietekmēja latviešu jūrnieka izredzes atrast darbu nozarē.

${ }^{69}$ BALODIS, Dažādās vietās un laikos, 9.-10. lp.

${ }^{70}$ Igauṇu jūrnieku brīdinājums. In: Latvija Amerikā, 24.01.1962., 8. lpp.

${ }^{71}$ BALODIS, Dažādās vietās un laikos, 18. lp. Citējumu sk.: BeITLERS, Latvijas jūrnieku ceḷi trimdā, 91. lpp.

${ }^{72}$ R. Mūrnieka vēstule Latvijas sūtniecībai Vašingtonā, 01.09.1960. LNA LVVA, 293-1-1946, 6. lp.

${ }^{73}$ BALODIs, Dažādās vietās un laikos, 18. lp.

${ }^{74}$ A. Dinberga vēstule L. Ķiplokam, 31.08.1950. LNA LVVA, 293-1-1943, 105. lp.

${ }^{75}$ L. Ķiploka vēstule J. Feldmanam. N̦ujorka, 26.08.1950. Ibidem, 106. lp.

${ }^{76}$ L. Ķiploka vēstule Latvijas sūtniecībai Vašingtonā saistībā ar dokumentāciju, kas nepieciešama Kanādas vīzas izsniegšanai. N̦ujorka, 17.10.1948. Ibidem, 108. lp.

${ }^{77}$ ASV Krasta apsardzes (Coast Guard) izsniegts paziņojums L. K,iplokam, 12.09.1950. Ibidem, 104. lp.

${ }^{78}$ L. Ķiploka vēstule A. Dinbergam, N̦ujorka, 16.09.1950. Ibidem, 103. lp.

${ }^{79}$ B. Senkeviča vēstule Latvijas sūtnim Vašingtonā. Portlenda, 01.01.1953. Ibidem, 115. lp.

${ }^{80}$ R. Mūrnieka vēstule Latvijas sūtniecībai Vašingtonā, 01.09.1960. Ibidem, 293-1-1946, 24. lp.

${ }^{81}$ K. Kirmuškas vēstule Latvijas sūtniecībai Vašingtonā. Curacao, 23.02.1955. Ibidem, 293-1-1943, 123. lp.

${ }^{82}$ BALODIs, Dažādās vietās un laikos, 18. lp.

${ }^{83}$ K. Kirmuškas vēstule no kuğa Latvijas sūtniecībai Vašingtonā. Ciudad Trujillo, 03.03.1954. LNA LVVA, 293-1-1943, 136. lp.

${ }^{84}$ K. Kirmuškas vēstule Latvijas sūtniecībai Vašingtonā. Jamaika, 28.02.1955. Ibidem, 122. lp.

${ }^{85}$ Latvijas diplomātiskie dienesti neko daudz nevarēja līdzēt, kad 1955. gada februāra beigās K. Kirmuškam bija jāizkāpj citas Dienvidamerikas valsts - Kubas - krastā: labākais, ko Latvijas Republikas pārstāvji varēja panākt, bija solīdu un komfortablu apcietinājuma apstākḷu izkārtošana - viesnīcā, pat ja bruṇotas apsardzes uzticamā pavadībā. Sk.: K. Kirmuškas vēstule Latvijas sūtniecībai Vašingtonā, 28.02.1955. Ibidem, 119.-122. lp.

${ }^{86}$ A. Dinberga vēstule K. Kirmuškam, 01.02.1955. Ibidem, 124. lp. Sūtniecības padomnieks raksta: "[...] sūtniecỉba [Jūsu lietā] [...] saņēmusi atbildi no Dominikāṇu vēstniecỉbas Vašingtonā. Atbildes saturs ir Jums labvēligs, un jāpien,em, ka turpmāk Jums nekādu grūtỉbu ar ieceḷošanu Dominikāņu republikā nebūs."

${ }^{87}$ R. Mūrnieka vēstule Latvijas sūtniecībai Vašingtonā. Savanna, 23.10.1960. Ibidem, 293-1-1946, 14. lp.

${ }^{88}$ Sk., piem.: A. Dinberga vēstule R. Mūrniekam, 31.10.1960. Ibidem, 15. lp.

${ }^{89}$ Sk.: K. Kirmuškas vēstule Latvijas sūtniecībai Vašingtonā, 28.02.1955. Ibidem, 293-1-1943, 122. lp. K. Kirmuška raksta, ka ar šo vēstuli vēlējies vienīgi informēt sūtniecību "par pēdējo [pasvītrojums mans - D. B.] stūrakmeni [resp., traucēkli - D. B.] latviešu jūrniekam Vakar-Indijas [domāta Dienvid- jeb Dienvidamerika - D. B.] republikās". 


\section{SUMMARY}

After the Second World War, a significant part of the sailors who originally were the Republic of Latvia citizens arrived in the Western countries as exiles. Many of them continued working in their speciality in the maritime structures of their new home countries. Often, despite a good education, Latvian sailors suffered from various restrictions, specific economic rules, political and ideological problems and also stereotypes regarding Latvian-people.

The first problem was economic protectionism of the states (aiming to protect the economic interests of their citizens), and the position of local, respectively, national, trade unions - they held a strictly negative attitude towards immigrants in the labour market; the seafarers' trade unions in the Scandinavia were particularly opposed to Latvian seafarers - refugees from the occupied Latvia. This problem, of course, was particularly common at the beginning of the post-war period, when many of the Western countries were economically weakened, but in some cases this phenomenon continued in later years.

The second problem or, more precisely, a block of problems, was the difficulties partly based in political reasons - with immigration authorities and the acquisition of citizenship. To sail on ships of many Western countries, the sailor was often required to be a citizen of the respective country. However, the acute lack of seafarers in some countries, support of international refugee care organizations - International Refugee Organisation, United Relief and Rehabilitation Administration - and status of the displaced persons enabled many Latvian refugees to continue their way and profession on the trading ships of Great Britain, Sweden, USA and other countries. Latvian sailors in exile always were greatly supported by the Latvian Legation in Washington D. C. and especially the Envoy Alfrēds Bīlmanis and the First Secretary of the U. S. Legation Anatols Dinbergs.

Some of the political problems were related to the political stereotypes linked with the certain political regime and state - the Soviet Union. Regardless of the quite famous political anti-Soviet activities of the Baltic exiles, in some countries of the world for several years after the war Latvian sailors were considered to be the representatives of the Soviet Union. That attitude was felt by Latvian sailors almost throughout the American continent and it greatly hindered seafarers' chances to travel by ship and to step ashore. The USA Immigration and Nationality Act of 1952 was particularly unfavourable to Latvian exile sailors in the West, as it was passed in the context of Cold War-era fears and under the suspicion of Communist and Soviet agent infiltration into American state institutions. "It is very painful to hear about the new [USA immigration] law, which has caused great injustice to Latvian sailors who do not have a fixed place of residence. [...] It turns out that Latvian sailors are communists or their supporters, or other types of untrustworthy persons," in January 1953 wrote Latvian seamen in exile Boleslavs Senkevičs. 


\title{
The Good People: Loyalty and Betrayal in Moscow's House of Government, 1937-1938
}

\author{
Labie ḷaudis: lojalitāte un nodevība PSRS Valdības namā \\ 1937.-1938. gadā
}

\author{
Yuri Slezkine \\ Professor of the Graduate School at the University of California, Berkeley \\ 3229 Dwinelle Hall \\ University of California \\ Berkeley, CA 94720-2550 \\ Senior Research Fellow, St. Edmund Hall, University of Oxford \\ Visiting Professor \\ Faculty of History and Philosophy, University of Latvia \\ Aspazijas bulvāris 5, Rīga, LV-1950 \\ E-mail: Slezkine@berkeley.edu
}

This essay is an abridged and revised excerpt from the book The House of Government: A Saga of the Russian Revolution. It deals with the reactions to mass arrests of 1937-1938 within the House of Government in Moscow, including silence, vigilance, book-burning, soul-searching, and self-sacrifice. The central questions have to do with the puzzle of what constituted moral behavior, what was meant by loyalty and betrayal, and who, and why, could be considered a "good person."

Keywords: Soviet repressions, Russian revolution, morality in extreme situations, House of Government.

Šis raksts ir saīsināts un pārveidots izvilkums no autora monogrāfijas "Valdības nams: Krievijas revolūcijas sāga". Tajā aplūkota reakcija uz masu arestiem Valdības namā 1937.-1938. gadā - tā ietvēra klusēšanu, pretestību, grāmatu dedzināšanu, garīgu un morālu pašanalīzi un uzupurēšanos. Galvenie jautājumi ir saistīti ar vairākām problēmām: ko nozīmēja morāla rīcība, kas tika saprasts ar lojalitāti un nodevību un kurš un kāpēc varēja tikt uzskatīts par labu cilvēku.

Atslēgvārdi: padomju represijas, Krievijas revolūcija, morāle ārkārtas apstākḷos, valdības nams.

The most common reaction to the multiplying disappearances in the House of Government was silence. Even the show trials were rarely commented on. The people in the government part of 
the House did not seem to doubt the guilt of the accused or the authenticity of their confessions: they seemed to refrain from mentioning them as a matter of ritual avoidance of the unclean. Only children and very old Old Bolsheviks might ask a question, which no one would consider answering. Even in prison reception rooms, the relatives of the arrested tried, according to Irina Muklevich, "not to talk and not to recognize each other. Hundreds of people would stand in a relatively small room, but it would be quiet and tense. They were all thinking of their own grief, like at a funeral." 1

On the last day of the KamenevZinoviev trial (August 1936), the chairman of the All-Russian Society for Cultural Relations with Foreign Countries (VOKS), Aleksandr Arosev (Apts 103 and 104), was in the Sosny rest home on the Moskva, writing in his diary.

"In today's papers we read that Kamenev, Zinoviev, Panaev, Mrachkovsky, Evdokimov, Ter-Vaganian, I. N. Smirnov Reingold, Goltsman, M. Lurye, N. Lurye, Dreitser, Olberg, and Perman-Yurgin have all been sentenced - to be shot.

M. P. Tomsky ${ }^{2}$ shot himself the other day.

Today Aralov told me that Comrade Piatakov had tried to poison himself, but apparently failed and was taken to the hospital.

No one is saying anything. Everyone talks as if nothing has happened.

'Did you go for a swim today?'

'No, I took a shower.'

At the other end of the table:

'Do you play tennis?'

'Of course.'

Someone else:
'Have some half-sour pickles. They're delicious." $" 3$

All Arosev himself had to say was that Kamenev and Zinoviev were "demons". Five months later, on the last day of the Karl Radek trial, he listed the sentences, copied a long excerpt from Lion Feuchtwanger's Pravda article, and agreed with the author that "only the pen of a great Soviet writer could explain to the people of Western Europe the crime and punishment of the accused." Arosev's own plan was to write a novel in the form of interrogation transcripts. Only "by means of aesthetic impressions," he wrote, could one make sense of "the zigzags that have brought people from the revolution to its opposite." This was true because Arosev was a fiction writer who hoped to represent the age with "the greatest possible generalizability." It was also true because there was no other way to make sense of the zigzags. One of the accused at the trial was Nikolai Muralov, whom Arosev, at Rozengolts's request, had appointed Commissar of the Moscow Military District on November 2, 1917. ${ }^{5}$

Another common reaction was to cleanse one's life of all connections to the excommunicated. Some House residents mostly women - burnt books and letters, cut faces out of photographs, changed their children's last names, and avoided contaminated neighbors and relatives. As in most struggles with the onslaught of the unclean, this was both a practical precaution and the extension of ritual silence to new sources of contagion. Some people reduced their possessions to a few things they might need in prison and waited silently for the knock on the door. The former head of the central censorship office, Boris Volin (Apt. 276), had a suitcase with warm things stored behind his couch. His wife burned the entire family archive. In the fall of 1937, he had a heart attack and 
was sent to the Kremlin hospital and then to a sanatorium in Barvikha. When he came back three months later, most of his neighbors and colleagues (he was First Deputy of the People's Commissar of Enlightenment) had disappeared. The former head of the Bookselling Directorate, David Shvarts (Apt. 444), would stay up at night, looking out the window. According to his son, "the window looked out onto the courtyard. Whenever a "black raven" [NKVD car] would enter the courtyard, my father would start getting dressed." 6

Attempts at self-cleansing and readiness for self-sacrifice were accompanied by vigilance toward others. Two and a half months after Sergei Kirov's murder (December 1, 1934), when he was still chief censor, Boris Volin issued an order informing local censorship offices that the "expertly camouflaged work of the class enemy" had been detected "on the fine arts front."

"By means of different combinations of colors, light and shadow, strokes, and contours disguised according to the method of 'mysterious drawings', the enemies are smuggling in counterrevolutionary content. The symbolic painting by the artist, N. Mikhailov, "By Kirov's Coffin", in which a certain combination of light, shadow, and color represent the outline of a skeleton, has been qualified as a disguised counterrevolutionary act.

The same has been detected on the tin can labels printed by Supply Technology Publishers (a human head instead of a piece of meat surrounded by beans). [...]

In light of the above, I order that:

All censors working with posters, paintings, labels, photo montages, etc. undertake the most thorough scrutiny possible of such material, not limiting themselves to superficial political meaning and overall artistic value, but considering carefully the entire artwork from all angles (contours, ornament, shadows, etc.), frequently resorting to a magnifying glass."

At the height of the campaign against hidden enemies, a magnifying glass was to be directed at everyone, by everyone. On July 27, 1937 (the day Osip Piatnitsky from Apt. 400 was arrested), the writer Aleksandr Serafimovich (Apt. 82) received a letter from his old friend, Mirra Gotfrid, asking for the telephone number of the head of the Writers' Union, V. P. Stavsky. She needed to talk to him about the novella she was translating by the Yiddish writer, David Bergelson.

"In the process of work on the translation I uncovered the petit-bourgeois nature of the novella and three subsequent meetings were enough to uncover something quite serious about the author it worries me very much I must see Comrade Stavsky believe me I wouldn't be bothering you for no reason. My observations are serious and this writer must be checked out very carefully. Write to Stavsky and ask him to receive me. You know I wouldn't be making a fuss over nothing. All the best to you. Thank you for all the good things. Warmest regards to Fekola. Why don't you do it this way send me Comrade Stavsky's phone number and drop him a line asking him to listen to what I have to say and telling him that I am observant and don't accuse people without evidence and that I would consider it a criminal act to keep silent and not report to the Writers' Union president (who is also a member of the Control Commission now). Help me out. Mirra, 27 July, 1937."

Platon Kerzhentsev from Apt. 197 also felt the need to be vigilant. In early March, 1938, he was at home awaiting arrest after his dismissal from the Committee for 
the Arts and the suicide of his deputy, Naum Rabichev. On the second day of the Anti-Soviet Rightist-Trotskyite Trial (March 1938), which involved three Kremlin doctors accused of murdering Soviet officials, he sent a handwritten note to Molotov, with a copy to Prosecutor General Andrei Vyshinsky:

"In connection with the charges against D. Pletnev, I consider it necessary to remind you of the circumstances of the death of Comrade Dzerzhinsky.

After his heart attack he was put in the room next to the meeting room. Several hours later the doctors allowed him to go back to his own apartment. When he got home and bent over his bed, he fell down dead.

As is well known, after a heart attack the patient is absolutely forbidden to move in any way (especially walking, bending).

Among the doctors attending to Dzerzhinsky was Pletnev.

By allowing Dzerzhinsky to go, he killed him.

\section{$[\ldots]$}

As for Kazakov, I can share my personal experience: my second heart attack happened exactly four hours after the very first injection administered by Kazakov.

Yours, Kerzhentsev, 8 March, 1938"9

Three days later, after the accused had had a chance to tell their stories, the head of the All-Union Radio Committee, Feliks Kon (Apt. 198), wrote to his lover, Maria Komarova, that their next meeting would have to be postponed because of bad weather, but that he would do his best to make up for it when the time was right. "Will I be able to? Will I? But I'll try. Okay?" His late love made him "feel alive, feel young again." And so did the spectacle of the Anti-Soviet Rightist-Trotskyite Trial. $^{10}$

"I miss you in earnest. Each time after I read the newspapers, I come close to losing my mind. Have entire generations struggled and have people died at the gallows, in dungeons, at the barricades, and in the Civil War just so these vermin could betray it all? Bukharin trying to kill Lenin and Stalin, Rozengolts with a prayer-amulet in his pocket ready to murder Stalin... Yagoda, Levin... It's like a villainy contest among scoundrels. And what about the attempt to poison Ezhov? You read something like this and then spend the rest of the day as if someone had spat into your soul. But still, despite all their scheming and their fascist conspiracies, we continue to advance, and now that Ezhov is in charge, things will get even better. If not for my 74 years, I would have approached Ezhov and volunteered to become his assistant. I would not have wavered. I would have killed those monsters with my own hand. I have lived through many assaults, but I never suspected that such creatures existed. Brrrr!"11

For Efim Shchadenko (Apts. 10 and 505), the struggle against wreckers was a time of revenge for years of humiliation at the hands of "neurotic degenerates" and other clouds in pants from "the intelligentsia in general and the Jewish intelligentsia in particular". Most recently, he had lost a protracted feud with the former tsarist officers and his superiors, the commander of the Frunze Military Academy, August Kork (Apt. 389), and the Deputy Commissar of Defense, Marshal Tukhachevsky (Apt. 221), both former tsarist officers. On August 17, 1936, Kork wrote to Tukhachevsky: 
"The state of health of my deputy, Comrade Shchadenko, is extremely precarious. It is my impression that, at any moment, Comrade Shchadenko may succumb to a fit of raving madness. I request that Comrade Shchadenko be relieved of his duties at the academy and transferred to the care of doctors without delay."

Tukhachevsky endorsed the request and Shchadenko was dismissed (and spent three and a half months in a hospital). In May, 1937, Kork and Tukhachevsky were arrested and, within three weeks, both executed. Their close colleague, Deputy People's Commissar of Defense, Yan Gamarnik (Yakov Pudikovich), committed suicide. Shchadenko was sent to Kiev to "liquidate the consequences of wrecking". On July 10, he wrote to an old Civil War comrade: ${ }^{12}$

"We must destroy this treacherous scum without mercy, the way we did during the Civil War, no matter what colors they use to camouflage themselves and no matter how leftist their reptile hissing may sound.

Death without mercy to the fascist lackeys, spies of the German-Japanese imperialism - such is our response to the scheming and sabotage on the part of the enemies of the people.

I am, as usual, merciless toward the enemy, hacking at them right and left, annihilating them along with their villainous acts." 13

On November 20, he wrote to another former comrade, reminding him of his (Shchadenko's) “implacable struggle against the German spy Kork, the vile governor scum Tukhachevsky, Gamarnik and the whole sellout gang of the Trotskyite-Bukharinist bloc." But his main correspondent, confidante, and fellow socialist realist was his wife,
Maria Denisova. On June 18, he wrote from Kiev:

"My darling little sun, I miss you so much and worry so much when, exhausted, I finally tear myself away from my work and drag myself to my - quite literally - soldier's bunk. There is so much work that I cannot leave Headquarters until 2 or 3 in the morning. The wrecker scum spent years fouling things up, and we only have weeks, or a month or two at the most, to not only liquidate all the consequences of sabotage, but to start moving forward. The cowardly scoundrels, undetected by the cheerful carelessness of our "defenders", sneaked into high positions, corrupted the guards, filled the apparently watchful sentries with the poison of doubt, and hatched an unimaginably villainous plot.

It is our great fortune that, early on, Stalin himself noticed and felt the danger of the fascist terrorist murderers getting close to him and began to take measures, not giving in to pleas for mercy for Enukidze (that most vile and well-disguised of reptiles), cast him, along with the rest of his gang, out of the Kremlin, recruited new, reliable guards, and, having appointed Comrade Ezhov, that modest and diligent worker, began to untangle the knots and threads of fascist designs for the bloody restoration of capitalism. [...]

I have a great deal of work, but working is easy because now I feel that I have vast creative freedom to fight with and for the masses, and, most important, that the truly great Stalin can, once again, see the same ability and selflessness that I demonstrated when he saw what I did during the Civil War.

I embrace and kiss you very tenderly, my darling little sun. Soon, no later than early 
July, I'll be in Moscow and then I'll try to bring my dear family back here with me."14

In November, he returned to Moscow as Deputy People's Commissar of Defense in charge of commanding personnel. Meanwhile, Maria herself seems to have succumbed to fits of raving madness. According to Maya Agroskina (Dementieva), who lived in Apartment No. 17 , she once broke into someone's apartment wearing a nightshirt and wielding a gun. According to Ruslan Gelman, who lived in Apartment No. 13.

"She lived in a huge apartment that had been converted from two smaller ones, with a few servants. Occasionally, she'd appear on the landing. She made a strong impression. She was a tall, stout woman with a piercing, menacing glare. Think of Surikov's [sic] painting, "Tsarevna Sofia": that's her portrait, as if she had posed for it herself. Add to that a long black dress girded by a soldier's leather belt, a kitchen knife stuck into it, and her hand resting on the handle... It was truly a sight to behold! To amuse herself, she used to leave a chair out on the staircase with a vase full of fruit and a tightly packed lady's purse with high-denomination bills sticking out. Sometimes that chair would remain there for several days.

Once she came over to our place. The only ones home at the time were me and our maid, a very young girl, who was deathly afraid of her. When I opened the door after the bell rang, the maid ran into the bathroom and locked herself in. The fearsome Tsarina swept past me, this time without her knife, but with a retinue: a young man in semi-military uniform. His job must have been to look after her, but he did not dare contradict or restrain her. She spent a long time looking around our apartment and even measuring some things, talking complete gibberish all the while, and finally left, with a parting threat." 15

\section{$* * *$}

Maria Denisova was trying to do at home what her husband was doing at work. Both had their sanity questioned by the people they tried to expose, and both were being vindicated by the daily exposure of "monsters in human form".

After the arrest of her seventeen-yearold son, Igor, Yulia Piatnitskaia began to question her own sanity. "I cannot even admit to myself the kinds of thoughts I am having about him," she wrote in her diary on February 25, 1938. "For as long as I have a bit of reason and a lot of love, I'll continue to wait. But I foresee torments terrible for my heart in the coming days." 16

Her heart's most terrible torment concerned the soul of her husband, who had been in prison for seven months. "Who is he?" she asked in her diary. "If he is a professional revolutionary - the kind he described in his book, the kind I saw in him for seventeen years, then he was struck by a terrible misfortune." But what if he is not? What if he actually is a monster in human form?

"It is clear that Piatnitsky has never been a professional revolutionary: he has been a professional scoundrel, a spy or secret agent like Malinovsky. That is why he has always been so grim and withdrawn. In the darkness of his soul, there was nothing to do but wait until he was discovered or managed to escape punishment.

We, his wife and children, have never been of much importance to him. Now, the question is: who did he serve? And why? He must have started because tailoring was hard and 
uninteresting, so he got involved in revolutionary work and, somehow, because of his cowardly nature, became a secret agent. Somebody must have discovered something: how he became a traitor or when he became a traitor, then the revolution happened and he realized how good the real struggle for socialism was, but the spies obviously would not let him work and he spent all those years working for the counterrevolution and surrounding himself with people like him. Piatnitsky's life could have gone like this. But who is he: this one or that one? I don't know, and it hurts. When I think of this first one, I feel so sorry for him and want to die or to fight for him. When I think of that second one, I feel tainted and disgusted, and I want to live in order to see them all caught and have no pity for them. I could spit in his face and call him a 'spy'. Vova must feel the same way." 17

Their twelve-year-old son, Vova (Vladimir), wanted to be a sniper and a border guard. "What a bastard Dad is," he said once, "to go and ruin all my dreams like that." On February 25, 1938 he spent all day reading a book about the Red Army. When he finished, he said: "It's too bad Dad hasn't been shot, since he's an enemy of the people."18

\section{"Yulia was not sure it was true.}

In the depths of my soul, in my inmost self, I clearly have no feeling of distrust for that man. He cannot possibly be an enemy of the Party he valued above all else in life. He cannot possibly be an enemy of the proletariat, whose interests he served all his life, to the best of his ability. It is still too early to talk about this without emotion. But the time will come, and you will still be certain of this, and your heart will sing because you will know that his thoughts and his heart were pure before the Party."
But then, why had he been arrested? The Party did not make mistakes, and Piatnitsky's arrest had been authorized by the Party.

"I trust Piatnitsky, but I trust Ezhov's holy work even more. 'Even the Sun can have an eclipse,' but nothing can eclipse the Sun. The Party is the Sun of our lives, and nothing can be dearer than its health, and if sacrifices are required (and if your life has been cut down by accident), find the strength to remain a human being, in spite of everything. My darling little Igor, my sacred little boy, I know you will understand everything if you do not die. You are too young to go through something like this."19

The only way to reconcile both sides of her heart was to think of Piatnitsky's arrest as a necessary sacrifice. This meant that Igor's arrest must also be a necessary sacrifice. But it was not. It was a redemptive trial.

"As for my Igor, I think along with F. [Engels]: "Whatever is healthy can withstand a trial by fire. The unhealthy elements we will happily discard..." The day of the great decision, the day of the battle of nations is near, and the victory will be ours."

She knew that Igor belonged among the chosen and was needed at Armageddon. It was Piatnitsky she was not sure about. ${ }^{20}$

Some relief was provided by the trial of Bukharin, Rykov, and other enemies. They were the ones "who had sowed mistrust, hostility, slander, and cruelty." Their unmasking and destruction would make it "easier to breathe". On March 3, the day Koltsov's article about the pack of bloodhounds came out, Yulia stayed home all day.

"I have used up all my physical strength. During the day, while I was alone in 
the apartment (Grandma had brought me the newspaper), I suddenly woke up with a stomach cramp. Without quite realizing it, I had broken into a 'dance of joy' at the decisive routing of those 'beasts'. To think that I used to respect some of them, although Piatnitsky had warned me about B. and what a scumbag he was. He told me about how he had sat on the floor in their midst, unshaven and clad in some old suit, and that no one had said hello to him. They already viewed him as a stinking corpse. And now he has turned out to be even more frightening, more treacherous than anybody could have imagined. 'Death' is too easy a punishment for them, but the working people should not have to breathe the same air as them. Oh Piatnitsky, you cannot be with them, my heart refuses to accept it.

If it must be, if they haven't withdrawn their accusations against you, then I will adopt the official view in all of my dealings with you and will never be near you, but I cannot think of you as a liar before the Party or a counterrevolutionary. But if it turns out to be true, can I remain among free Soviet citizens? And die? At a time when the dark forces are rising against us, when the last and perhaps decisive battle is coming, and soviets are being formed in other countries? And leave my children behind? I feel like I can't sleep, don't want to see anyone, don't want to move. It frightens me to be wearing Piatnitsky's slippers (flat ones with no heels), and I feel really sick to my stomach after my dance. This was the first time my body has been inspired by anything since Piatnitsky's arrest." 21

Yulia and Vova followed the trial in the newspapers. Vova read the transcripts every day after school. He asked his mother how the murderers had prepared poison and told her that he thought Koltsov's description of Krestinsky's attempt to retract his testimony was very funny. ("In a brilliant display of cross-questioning, the public prosecutor Comrade Vyshinsky corners the mangy Trotskyite rat. Its squeaking is growing more confused.") They spent their evenings reading Jules Verne's The Mysterious Island aloud. On March 13, the sentences were announced. ${ }^{22}$

"Today at 4 p.m. they will be liquidatedthese terrible villains of our land. They managed to weave such a vast and intricate web that even those who hate them as much as Comrade Ezhov hates them and as much as every honest and conscientious citizen of our country hates them have been caught up in it. In addition to the colossal material damage, they have inflicted moral wounds on us. So much remains to be untangled, pondered, destroyed, cured, and neutralized in time, and among them there is, of course, some of the 'living flesh' of Lenin's and Stalin's Party, whose suffering has been immeasurable, even though I have only a dim understanding of it. Who will pay for it? Who will give back the lost months of my life, the possibility of working shoulder to shoulder with my comrades at such a time? Who will make up for this unmarried loneliness? Their disgraceful, vile blood is too small a price for all the grief felt by the Party and by all those who have some feeling left, for the suffering of those innocent people who have been removed from society, people who have given everything for the revolution, every drop of their strength, not realizing that there existed such two-legged monsters, such cretins who were so good at dissembling. I do not know of a more terrible creature than Bukharin, it is hard for me to express what I feel. Now they will be destroyed, but my hatred will not be diminished. I would like a terrible punishment for them - we could put them in cages built especially for them in a museum, 
labeled 'counterrevolutionaries', and take care of them as if they were rare specimens. That would be terrible for them: citizens would come and look at them the way you look at animals. Hatred for them would never die, and they would be forced to see how we fight for a happy life, how united we are in our struggle, how much we love those of our leaders who remain true, how we triumph over fascism while they sit around idle, being fed like animals and not being considered human. [...] I curse you all, curse you for eternity." 23

On March 9, she went to see the chief military prosecutor, Naum Rozovsky. She was nervous and, according to her diary, "spoke unintelligently and said all the wrong things." So did the prosecutor.

"Comrade Rozovsky is also exhausted, he screamed at me angrily, with great emotion. I even felt sorry for him, for I only subsist while he works, and such a hard job it is, too. Oh, how dear they are to me, how I wish they could trust me! I would happily give my life for something useful, but coming from me it must sound untrue... I know that the best thing for me is death. But then again, it's probably wrong for me to kill myself. What did I feel in Rozovsky's office? One should always rise above one's private interests - always, but especially in my state, when I have and will have nothing, so I must find work I can live for." ${ }^{24}$

Such work could be found. She needed the NKVD in order to find out what had happened to her husband and son; she admired the NKVD for the difficult work they were doing; and she needed the NKVD's trust in order to resolve her doubts. Working for the NKVD might be the best, and perhaps the only, way to become whole again. On April, 14, she went to see Rozovsky again.
"I spoke of my intention of putting myself at the disposal of the NKVD and military organs. He told me that I should express this wish in writing and not be shy about being long-winded, so that I could make myself completely clear. He did not promise anything concrete, but he did promise to try to help me. The letter must be handed to Medvedev. He must have been as humane with me as his position allowed. I could tell that he was exhausted and that he truly cared. I shook his hand firmly, although perhaps that was excessive sentimentality, which I keep trying to overcome, but when I saw in him a person who was doing a job that was difficult yet so necessary at this time, I wanted to express my admiration for those comrades, my heartfelt kinship with those who are uprooting all kinds of scum from our Party." 25

It did not work. Next time she saw Rozovsky, he was cold and indifferent. She began to doubt the one thing that had seemed solid.

"The most frightening thing within me is the growing distrust for the quality of people who conduct investigations and have the right to arrest. Of course, I realize that Ezhov and some others, both top-level and low-level officials, are wonderful, genuine people who are doing extraordinarily difficult work, but the majority - they are also doing difficult work, but as stupid and petty people capable of meanness. It's a shame I feel this way, but the facts (the things I have experienced myself, things I have seen, as single strokes here and there, things I happen to have heard from other people standing in prison lines) make it impossible to feel differently." 26

She tried to talk to different people, but they would not listen. Some laughed at her. She used to have Piatnitsky to talk to, but he was not there anymore and might 
or might not be the reason for the silence that surrounded her. The last entry in her diary, under May 28, 1938, is:

"I used to talk his ear off, but I never needed anyone else to talk to, and I still won't, except perhaps to someone from the NKVD. In spite of everything, I feel closer to them." ${ }^{27}$

Several weeks later she got a job as an engineer at a hydroelectric power plant in Kandalaksha, on the White Sea. She took Vova with her. On October 27, 1938, she was arrested for telling an NKVD informer that her husband was innocent. Her diary was used as evidence against her. She was sentenced to five years in a labor camp and sent to the Dolinsky Camp in Kazakhstan, where she saw Igor. Vova ran away to Moscow and was taken in by the family of his friend, Zhenia Loginov, from Apartment No. 89. After three months of living with the Loginovs, Vova overheard one of them say that his stay was causing Zhenia's father problems at work, so he went to the Executive Committee of the Moscow City Council and was sent to an orphanage. ${ }^{28}$

\section{$* * *$}

According to the grown-up Vladimir Piatnitsky, Zhenia Loginov's father worked in Stalin's secretariat. The Loginovs' act taking in the enemy's progeny - was uncommon, but not unheard of. But most "family members of traitors to the motherland" (as they were described in Order No. 00486) were helped by other family members. And most families' central figure - not targeted by the mass operations and not questioning the duty to help - was the grandmother. Svetlana Osinskaia's maternal grandmother, Ekaterina Nartsissovna Smirnova, was not unusual.
"She was quiet, but firm and unflappable. Short, with soft grey hair cozily pinned back with horn hairpins, she wore long, dark skirts and buttoned-up blouses with a tie or bow at the collar and a small brooch with tiny pearls. Several letters from my grandmother to my mother that I have kept suggest that she was a person of great integrity. Her letters are plain: she talks unaffectedly about her health and simple chores, but her dignity comes through clearly. Those traits of hers bordered on coldness. She was never openly affectionate with us or particularly curious, and never singled anyone out. With the calm of a self-confident and deliberate person, she made jams at the dacha, provoking my great admiration for her ability to remove cherry pits by means of a hairpin, mended clothes, and made wonderful toys for New Year's: a tiny little chest with blue silk lining, a small leather bag stuffed with candy, and little dolls in bright dresses. Spared miraculously by life's upheavals, they stayed with me for a very long time. When my parents were arrested, she did not become frightened, but came over the morning after my father's arrest and stayed with my mother until she was arrested. After that, she came over almost every day and did her best, along with several other people, so that we could go on with our normal lives." ${ }^{29}$

She did eventually take Svetlana (who was twelve), Rem (fourteen), and Valia (fifteen) to an orphanage - she lived with her niece in a twelve-meter room in a communal apartment, - but she remained the center of the truncated family and regularly sent news, food, and money to her daughter and grandchildren. The same was true of Arkady Rozengolts's mother-inlaw, who took care of her grandchildren until the war made it impossible. Many children, including Inna, Natalia, and Valentina Gaister, Yuri and Tania Trifonov, 
and Rada Poloz (Tania Miagkova's daughter), were raised by their grandmothers all of whom were described as dry, unsentimental, and unquestioningly devoted. The fact that two of the three - Tatiana Aleksandrovna Slovatinskaia and Feoktista Yakovlevna Miagkova - were orthodox Bolshevik sectarians does not seem to have diminished their family loyalty. The fact that their families were punished for unexplained reasons does not seem to have diminished their Bolshevik orthodoxy. The two sets of loyalties - shared by their children, instilled in their grandchildren, and maintained painstakingly to the end of their lives - were connected to each other by silence.

Uncles and aunts - the brothers and sisters of arrested enemies - had a more difficult choice to make. They were vulnerable to arrest and had reason to believe that associating with a contaminated relative might increase the risk. Some had children of their own, to whom they owed primary loyalty. Some were members of the Party, to which they owed primary loyalty (and from which they expected extra scrutiny and harsher punishments). Some were both parents and Party members.

The children of the People's Commissar of the Food Industry, Abram Gilinsky, twelve-year-old Nelly and two-year-old Tania, were sent to an orphanage, but Nelly refused to cooperate ("breaking windows, rolling on the floor"), until the principal informed her aunt (her mother's sister, Lydia Mefodievna Stechkina). When the aunt arrived, she asked the principal what would happen to her and her husband, both Party members, if they adopted the two girls. The principal said (accurately, according to Order No. 00486) that there would be no negative consequences, and the aunt took them back with her. The six of them - Nelly and Tania, their aunt and uncle, and their aunt's grown-up adopted daughter and her husband - shared two rooms in a communal apartment. Nelly and Tania were to call their aunt and uncle "mom" and "dad". A month later, the uncle, Vasily Stepanovich Kraiushkin, was arrested. The aunt went on to become the girls' adoptive mother. (Their mother died in exile in 1949.) Their half-brother, the nineteen-year-old David (Gilinsky's son from a previous marriage) became "like a father" to them. Gilinsky's three brothers, who lived in Leningrad, helped out the best they could. ${ }^{30}$

When the Deputy Commissar of the Defense Industry, Romuald Muklevich, returned home to Apartment No. 334 after the arrest of his wife, Anna (Head of Supplies at the State Planning Committee), he was visited by his brother-in-law and old Civil War comrade, the director of the Aviation House, Matvei Yakovlevich Sheiniuk. Muklevich's daughter, Irina, heard her uncle say that, if Muklevich was arrested, he would take Irina to live with him and take care of her as long as he lived. After Muklevich's arrest, he did take her to live with him. Several months later, he, too, was arrested, and Irina was raised by her aunt and grandmother. ${ }^{31}$

Was Sheiniuk arrested because of his loyalty to the Muklevichs? No one knew for sure, but it made sense to assume a connection. When the People's Commissar of State Farms, N. N. Demchenko, and his wife, Mirra Abramovna, were arrested, their eldest son, nineteen-year-old Kolia, talked his uncle into sheltering his eleven-year-old brother Feliks (named after the founder of the Cheka). When he next came to visit, his uncle opened the door without undoing the chain and told him through the crack that, in order to sever all links with the enemies of the people, he had taken Feliks to an orphanage. At the orphanage, Kolia was told that he was not in a position to adopt his brother. In order to qualify, Kolia 
married his girlfriend, Tatiana, thereby provoking the "desperate envy" of his roommate, Samuil Moroz. A week later, both Kolia and Samuil were arrested. ${ }^{32}$

Inna Gaister's Uncle Veniamin (a researcher at the Institute of World Economy and International Politics), attempted to cut off all contact with his arrested relatives, but was seemingly left with no choice but to take in his mother, who was visiting from Poland, after three of his sisters (Lipa, Adassa, and Inna's mother, Rakhil) were arrested. Their twentyyear-old brother Lyova was a student at the Bauman Institute at the time. As Inna writes in her memoirs,

"After my mother and Lipa were arrested, Grandma Gita went to live with Adassa. After Adassa was taken to prison, her son Veniamin took her in. Sometime in early December, Elochka, Aunt Lipa's daughter, came home from school one day to find Grandma Gita sitting on the stairs in front of their apartment. Veniamin, without warning Niuma (Lipa's husband) or Lyova, had brought her there and left her by the locked door. Grandma moved in with them. I would often see her there. She was no longer the same proud and happy Grandma I had seen arrive from Poland. I can still picture her with her red wig all twisted round and her bun hanging over her ear. She could not understand why her children had been imprisoned. She kept pacing up and down the apartment, intoning: "It's all my fault. I have brought grief to my children. I must return home immediately. As soon as I leave, things will get better again." She was saying all this in Yiddish. Of course, Elochka and I did not understand a word of Yiddish, so Lyova had to translate for us." ${ }^{33}$

Inna's mother, Rakhil Kaplan, had been sent to the Akmolinsk Camp for Family Members of Traitors to the Motherland in
Kazakhstan. One of her letters contained a note to Veniamin, in which she asked him to take care of her children.

\begin{abstract}
"After what had happened with Grandma Gita, I did not want to go to Veniamin. But Niuma and Lyova talked me into taking the note to him, and so Lyova and I went over to his place. He and Sarra were home. They took my mother's note and went into his study. Then Sarra came out and said: 'Go away and never come back'. Veniamin did not come out. Lyova and I left without saying a word. That did not save Veniamin from prison, however." 34
\end{abstract}

Dima Osinsky's wife, Dina, was being exiled to Kharkov, which meant that his younger siblings Svetlana and Valia and their adopted brother Rem Smirnov would have no place to live and be taken to an orphanage. According to Svetlana,

"The matter resolved itself, somehow. We would go to the orphanage, but not for long because, of course, everything would soon be cleared up. But, just in case, Dina sent us over to my father's sister, Galina, who was also my mother's closest friend, to ask for advice. She lived with her husband, the chemist, S. S. Medvedev, the future famous scholar and full member of the Academy of Sciences, and their son, who was a little younger than me. I had been to their place - three small rooms in a communal apartment in a tall building with a dark stairway on the corner of Krivokolenny and Armiansky Alleys - many times before with my mother. The walls of Galina's room were covered with pictures, including a large portrait of her: a handsome, thin, perfectly proportionate face, dark wavy hair, and a blue blouse with a wide-open white collar. Next to it were some of her own drawings. Aunt Galia was an artist and worked at the Vakhtangov Theater. 
That spring day in 1938, Valia and I went to Aunt Galia to ask advice about our future, which had, in fact, already been decided. We climbed up the tall staircase and rang the doorbell. Aunt Galia opened the door. My God how scared she was! She didn't know what to do. We stood in our coats in the large dark entryway, while she disappeared somewhere into the bowels of her rooms. Soon she came back and started stuffing our pockets with candy. 'You can't stay here,' she said quickly and softly, 'Sergey Sergeevich is working. He mustn't be disturbed.' She kept pushing us gently toward the door. When we had all walked out onto the stairway, she seemed relieved. 'Don't ever come back again, okay? Now go.' So we left and walked home in silence. When he got home, Valia, who had never cried once during those six months, buried his face in his pillow and sobbed." ${ }^{35}$

Close friends were in a similar position - and were frequently referred to as "uncles" and "aunts". One of Irina Muklevich's real aunts, her mother's sister Maria, had a friend named Anton Ionych Shpektorov, an official at the People's Commissariat of External Trade (headed, after Rozengolts's arrest, by A. I. Mikoian). He had "a personal car with a chauffeur, two secretaries, and the use of the government cafeteria, exclusive sanatoria, etc., etc.", but he "was not afraid of anything and came to see us almost every day." (He may have been in love with Irina's aunt, but the risk remained the same, whatever the reason for such open loyalty). Other friends, according to Irina, acted differently. ${ }^{36}$

"Three days after my father's arrest, my aunts Nina and Meli (my father's sisters) walked into the entryway and saw my parents' close friend, the Old Bolshevik, Mikhalina Novitskaia [Michalina
Nowicka], who had worked for many years at TASS, as Doletsky's personal secretary. They were all waiting for the elevator. When she saw my aunts, Mikhalina did not say hello and did not enter the elevator. She simply stepped aside and turned away. My aunts were shocked. It was as if she had spat in their faces.

Of course, Mikhalina did not know then that a month later her own husband, an old Bolshevik and top official of the Comintern Executive Committee [Waclaw Bogucki], would be arrested; she would be sent to a camp for eight years; and her son [Vladimir] would be taken to an orphanage. And that after her return she would spend many years looking for her son and that she would never find him because he had been sent to prison for ten years for stealing a watermelon and a cantaloupe from the field when he was hungry. And that she would come to me when she had no place to go in Moscow, and I would take her in. All that happened. She would end her days in a retirement home, lonely and sick." 37

In memoirs and reminiscences, such actions are featured prominently and represented as acts of betrayal, often followed by providential retribution. Most House of Government residents - including those like Piatnitskaia, who thought of themselves as Bolsheviks and were not convinced of their relatives' (or even their own) innocence before the Party seem to have expected loyalty from their friends, lovers, and relatives, irrespective of whether they were Party members or not. Some self-sacrificial actions and individuals might be singled out for admiration, but most such actions and individuals were mentioned without comment, as part of the normal course of things. Friends, lovers, and relatives were, then and later, 
depicted as having been subjected to a test of humanity. Some passed, proving themselves to be "true" (in the sense of both "loyal" and "genuine"), and some did not. And since friends, lovers, and relatives were expected to be true, by definition, those who did the right thing might or might not, depending on the other factors involved, be seen as heroic. Those who did not were consistently singled out - and often deliberately exposed - as traitors and "bad people". There were countless shades of grey, forgiven trespasses, and attenuating circumstances in between, but the endpoints on the scale of goodness were clear enough. "Good people" were those who were prepared to risk their own safety and that of their immediate family for the sake of friends, lovers, and other relatives. "Bad people" were those who wished to protect themselves and their immediate family to the exclusion of all other loyalties and commitments. The orthodox Bolsheviks who turned away their nephews and nieces because the only true family was the Party were acting like bad people. In accounts written in the post-sectarian world, these orthodox Bolsheviks and bad people became indistinguishable. Feliks Demchenko's and Inna Gaister's uncles were bad people - both at the time and in the retelling - irrespective of whether their reasons were self-servingly egotistical or self-denyingly sectarian.

Family morality within the House of Government, like the sectarian morality of Party purges, was centered on trust and betrayal. But whereas the purge morality was concerned with secret thoughts as opposed to actions (or rather, with hypothetical actions as emanations of deviant thoughts), family morality was focused on actions as proof of moral choices. Lydia Mefodievna Stechkina, Matvei Yakovlevich Sheiniuk, and Anton Ionych Shpektorov were good people irrespective of whatever private fears they may have had to overcome. Indeed, they were all the more remarkably good people for having overcome their private fears and silently reconciled their sectarian commitments with those toward kith and kin (all three were Party members). The Party itself could not quite make up its mind: it exiled entire clans and punished "family members of traitors to the motherland," while proclaiming, from Stalin's mouth, that "sons do not answer for their fathers" and encouraging, inconsistently but forcefully, the reintegration of those sons into the Soviet family. In a note to her from prison, Irina Muklevich's mother wrote: "Whatever happens to us, always remain a true Soviet." And that is how Irina's aunt, a good person and a true Soviet, brought her up. The key to being a good Soviet while having a mother in prison was silence. ${ }^{38}$

The more intimate the relationship and the thicker the web of mutual obligations, the greater the expectation of loyalty and the more painful the betrayal (very rare in the case of parents and children). The more distant the relationship and less anticipated the favor, the greater the virtue. The Loginovs took in an enemy's son because he was their own son's friend. Irina Muklevich had a school friend, Shura Elchugina, who lived in the dormitory for Military Academy cadets across the river. (Her father was a maintenance worker at the Academy.) After the arrest of Irina's parents, the Elchugins invited her to stay at their place, and Shura's mother made her a dress. Vasily Shuniakov, a former Petrograd worker and Central Control Commission official specializing in purges and his wife, Iudif Charnaia, a former seamstress and education official specializing in pedology (until it was banned by Volin and Rabichev), let their daughter's friend, Katia Dushechkina (from Apartment No. 422), stay with them for a while after 
her parents were arrested. According to their daughter, Tamara, they were visibly frightened by what was happening and burned many of their books; Vasily started drinking. ${ }^{39}$

The former chairman of the Flour Milling Industry Directorate, Boris Ivanov, his wife, Elena Yakovlevna Zlatkina, and their three children (Volodia, Anatoly, and Galina) occupied two rooms of their threeroom apartment and rented out the third. Their first tenant, Professor Lebedev, was arrested very early, perhaps as early as 1935. Their next tenants were a MarxismLeninism instructor named Krastinšs, and his wife and daughter. Once, in the middle of the night, the doorbell rang. Anatoly, who was seventeen at the time, opened the door, saw several NKVD agents, walked over to where his father was sitting at his desk (he used to work late), and said: "Get up, Dad, it turns out you're a bastard. They've come for you." The agents came in, asked everyone for their names, and moved on to the room where the Krastiňs lived. A few days later, that room was occupied by the wife and two daughters of the recently arrested head of the CattlePurchasing Trust, N. A. Bazovsky, from Apartment No. 377 three floors above. Shortly afterwards, Bazovsky's wife was also arrested. Her daughters were not home at the time, and Elena Yakovlevna told Anatoly and Galina (who was fifteen) to save as many of the Bazovskys' belongings as they could. She also told Galina to stand watch downstairs and warn the Bazovskys' older daughter, Nina, not to come up. (The younger one, Olga, was out of town, visiting her aunt.) The guard on duty, named Niura, told Galina to go back to her apartment and promised to call her when Nina showed up. (According to Galina, the guards liked her family and treated them well.) She did; Galina warned Nina; and Nina went to live with her relatives. Meanwhile, the husband of Elena Yakovlevna's sister, an aviation engineer, had been arrested, and the sister had moved in with the Ivanovs. One day, on the Big Stone Bridge, she ran into the fifteen-year-old Olga Bazovskaia, who told her that her aunt had thrown her out and that she had no place to stay. Elena's sister invited her over, and she ended up moving in with them. Boris Ivanov (who had known the Bazovskys as apartment neighbors for about three months) registered her in one of his two rooms. (The third room was now occupied by the Commissariat of Finance official, V. M. Buzarev, and his family.) Galina and Olga became close friends and treated each other like sisters. According to Galina, her parents remained orthodox Bolsheviks. Her father had recently become secretary of the Party organization and head of the personnel department at the People's Commissariat of Food Industry; her mother was a member of the Moscow City Soviet. They never talked about their arrested relatives and neighbors, including Olga's parents. When Krastiņš returned from prison a year or so later, he stayed with them for several days. According to Galina, he had no teeth and was dressed in rags; he went straight to the bathroom, saw the soap, and started crying. Olga lived with the Ivanovs for about ten years; they raised her as a daughter. When Olga's mother came back from the camps, she also stayed with them for a while. According to Galina, she once said: "If I had been in Elena Yakovlevna's place, would I have done what she did? Would I have taken Galka in? No." The world was divided into good people and bad people. Everyone - Party and non-Party seemed to agree that Boris Ivanov, the baker, and his wife, Elena Yakovlevna Zlatkina, were very good people. ${ }^{40}$ 
The Elchugins', Shuniakovs', and Ivanovs' actions may have had something to do with the fact that they were former workers and peasants, not "students", and that they assumed that being a good Soviet was compatible with fulfilling traditional neighborly and kinship obligations (just as it was compatible with not celebrating New Year's Eve and grownups' birthdays). Perhaps they found it easier to use silence as a bridge between faith and social practice. The House of Government's most articulate intellectuals and prominent experts on Bolshevik morality - the author of Soviet family law, Yakov Brandenburgsky, and his coauthor and chess partner, "the Party's Conscience" Aron Solts, - were not up to this task. In late 1936, Brandenburgsky, who was then chair of the Collegium for Civil Cases of the Soviet Supreme Court, began to act strange, telling his family that he was afraid to go to work. In December, his wife and twenty-three-year-old daughter, Elsa, received a call from the mental hospital ("Kanatchikov's Dacha") that he had been picked up on the street in a state of complete disorientation. After some time, they were allowed to bring him home, but he refused to eat and was taken to the Pirogov Hospital. "When we came to visit," said his daughter in an interview sixty years later,

"We found a complete stranger, suffering from fatigue. A sybarite by nature, he seemed totally unaffected by the company of madmen, screaming, squealing, and crawling on the floor beside him. The room was filled with very sick people, but my father seemed perfectly comfortable there. He had even found a friend - a dwarf with a contorted face, - whose company he seemed to enjoy. [...] He would sometimes say things that made no sense to us. Once he became agitated: 'Why did you write my name on the box of chocolates? They might find me that way!'41

In late 1938, after the mass operations were over, Brandenburgsky suddenly recovered and returned home. He retired from the Supreme Court and became a volunteer lecturer at the Moscow Party Committee. He died in 1951 at the age of seventy, while playing chess. He never talked about his illness. ${ }^{42}$

Solts served as First Deputy Prosecutor General for Criminal Cases and lived with his adopted son, Evgeny, and his niece, Anna Grigorievna Zelenskaia. His sister, Esfir, had died in 1935. After the arrest of Anna's former husband, Isaak Zelensky, their two children, eighteen-year-old Elena and sixteen-years-old Andrei, joined their mother in Solts's apartment, and he adopted them, too. On February 14, 1938, he had a violent argument with his boss, the Prosecutor General A. Ya. Vyshinsky, about the case of his friend and disciple, Valentin Trifonov, who had been arrested on June 21, 1937. According to Elena, he came home very upset and said that Vyshinsky had threatened him, too. He decided to stop eating in the hope that Stalin would agree to talk to him. Several days later, he was taken to the ward for the violently insane at the Sokolniki PsychoNeurological Hospital. According to his doctor, who knew him from her previous work as consultant for the Amnesty Board, which Solts chaired, he blamed the demise of the Old Bolsheviks on the rise of opportunists. "'Who is Ezhov? Why should I believe Ezhov? The Party does not know Ezhov!', Solts would say. 'Vyshinsky, a former Menshevik, is going to interrogate me? A Menshevik is going to sit in judgment over Bolsheviks?!" He abandoned his hunger strike and, a month and a half later, 
was allowed to return home in exchange for a guarantee from his niece Anna that he would not pose any danger to himself or others. Two and a half months later Anna was arrested. Solts wrote a letter to his former colleague, the chairman of the Military Collegium of the Supreme Court, Vasily Ulrikh, but received no response. He was removed from his position and then worked as a literary consultant for the Young Guard Publishers and director of the archive of the Museum of the Peoples of the USSR, before retiring in 1940 at the age of sixtyeight. "He suffered terribly from the enforced idleness," wrote Elena. "He spent hours lying in bed reading or pacing around the apartment writing long columns of numbers on pieces of paper or in newspaper margins." 43

\section{ATSAUCES UN SKAIDROJUMI}

${ }^{1}$ I. R. MukLEvich. Dear friend [in Russian]. Arhiv muzea "Doma na naberežnoi" [House on the Embankment Museum archive], Moscow (hereafter - AMDNN), file 28.

${ }^{2}$ Mikhail Tomsky (1880-1936) committed suicide in 22 August, 1936 (editor).

${ }^{3}$ Olga Aroseva. Prozhivshaia dvazhdy, 24 August, 1936. Available: http://lib.rus.ec/b/387149/ read

${ }^{4}$ LION FeJHTVAnger. Pervye vpechatlenija ob jetom processe. Pravda, 30 January, 1937.

${ }^{5}$ Ibidem.

${ }^{6}$ V. B. Volina interview, 18 September, 1997; V. D. Svarts interview, 10 September, 1998. "Black raven" was a colloquial term for "prison van".

${ }^{7}$ VASILII SoIMA. Zapreshchennyi Stalin. Moskva 2005, pp. 97-98.

${ }^{8}$ Rossijskij gosudarstvennyj arhiv literatury i iskusstv, Moscow, 457-391, pp. 199-199 ob.

${ }^{9}$ Gosudarstvennyj arhiv Rossijskoj Federacii, Moscow, 5446-82-65, pp. 182-184.

${ }^{10}$ Rossijskij gosudarstvennyj arhiv social'no-politicheskoj istorii, Moscow (hereafter - RGASPI), 135-2-19, p. 57.

${ }^{11}$ Ibidem, pp. 56-56 ob.

${ }^{12}$ Ibidem, 74-2-105, pp. 41-2, 47, 51, 55, 59-60 (cited in: BoRIs SoKOLOv. Dva marshala: Tragicheskii roman v pis'makh. Grani.ru, 21.02.2003. Available: http://grani.ru/Society/ History/m.23664.html); Rossijskij gosudarstvennyj voennyj arhiv, Moscow (hereafter - RGVA), 37461-1-134, p. 25.

${ }^{13}$ RGVA, 37461-1-134, pp. 15-15 ob.

${ }^{14}$ Ibidem, 37461-25-128, pp. 7-9.

${ }^{15}$ AMDNN, Ankety. Otvety M. I. Dement'evoi (Agroskinoi); AMDNN, Ruslan Nikolaevich Gel'man, Letter to the Museum.

${ }^{16}$ VlAdimir PiAtnitskiI. Golgofa. Po materialam arkhivno-sledstvennogo dela No. 603 na Sokolovu - Piatnitskuiu Iu. I. Leningrad 1993, p. 46.

${ }^{17}$ Ibidem, pp. 41-42.

${ }^{18}$ Ibidem, pp. 56, 46.

${ }^{19}$ Ibidem, pp. 63-64.

${ }^{20}$ Ibidem, p. 61.

${ }^{21}$ Ibidem, pp. 51-53.

${ }^{22}$ Ibidem, p. 57; Mikhail Kol'Tsov. Svora krovavykh sobak. In: Pravda, 03 March, 1938.

${ }^{23}$ PIATNITSKII, Golgofa, pp. 57, 60-61. 
${ }^{24}$ PIATNITSKII, Golgofa, p. 79.

${ }^{25}$ Ibidem, pp. 82-83.

${ }^{26}$ Ibidem, p. 103.

${ }^{27}$ Ibidem.

${ }^{28}$ Ibidem, pp. 13-16, 104-120; INNA SHIKHEEVA-GAISTER. Deti vragov naroda: Semeinaia khronika vremen kul'ta lichnosti 1925-1953. Moscow 2012, pp. 55-57.

${ }^{29}$ Svetlana OBolensKAiA. Iz vospominanii. Available: http://samlib.ru/o/obolenskaja_s_w/01. shtml

${ }^{30}$ N. A. Gilinskaia interview, 02 March, 1998.

${ }^{31}$ Muklevich, Dear friend. AMDNN, 12; I. R. Muklevich interview, 07 November, 1997.

32 Nikolaj N. DemchenKo. Kanikuly dlinoi v 18 let. In: Mendeleevets 36, 1988, No. 1799.

${ }^{33}$ SHIKHEEVA-GAISTER, Deti vragov naroda, pp. 57-58.

${ }^{34}$ Ibidem, p. 66.

35 Obolenskaia, Iz vospominanii; SvetLana OBolEnsKaIA. Deti Bol'shogo terrora: Vospominaniia. Moscow 2013, pp. 55-56.

${ }^{36}$ MuKLEvich, Dear friend. AMDNN, pp. 62-63.

37 Ibidem, pp. 24-25; Vladimir V. BOGUTSKII. Vospominaniia. C AOM. Archive of the Memorial Society, fond 2 (memoir collection), pp. 7-8.

${ }^{38}$ See Golfo Alexopoulos. Stalin and the Politics of Kinship: Practices of Collective Punishment, 1920s-1940s. In: Comparative Studies in Society and History 2008, No. 1, pp. 91-117; CYNTHIA HOOPER. Terror of Intimacy: Family Politics in the 1930s Soviet Union. In: CHRISTINA KIAER, ERIC NAIMAN (eds.). Everyday Life in Early Soviet Russia: Taking the Revolution Inside. Bloomington 2006; AMIR WEINER. Nature, Nurture, and Memory in a Socialist Utopia: Delineating the Socio-Ethnic Body in the Age of Socialism. In: American Historical Review 104, 1999, No. 4, pp. 1114-1155.

${ }^{39}$ MukLEVICH, Dear friend. AMDNN, pp. 30-1; I. R. Muklevich interview, 07 November, 1997; T. V. Shuniakova (Ignatashvili) interview, 22 April, 1998.

${ }^{40}$ G. B. Ivanova interview, 13 March, 1998.

${ }^{41}$ IUdit AgracheVA. Chlen partii s 1903 goda. Vesti-2, 01 June, 1995.

${ }^{42}$ Ibidem; "Biografiia" and "Avtobiografiia". AMDNN, the Brandenburgsky file, KP 371/17, KP 3771/18.

${ }^{43}$ E. I. ZelensKaiA. A. A. Sol'ts. Unpublished manuscript. AMDNN, "Solts" file, pp. 68-92; C. YURY TRIFONOV. Disappearance. Translated by David Lowe. Ann Arbor 1991, pp. 99-100; C. YURY TRIFONOV. Ischeznovenie. Available: http://royallib.ru/read/trifonov_yuriy/ischeznovenie. html\#0

\section{SUMMARY}

This is an abridged and slightly revised version of a chapter from my book The House of Government: A Saga of the Russian Revolution (Princeton University Press, 2017). The House of Government - also known, after Yuri Trifonov's novella, as the House on the Embankment - was built in central Moscow during the first Five-Year Plan in order to serve as a home for the members of the Soviet government. The largest residential building in Europe, it combined 505 fully furnished family apartments with public spaces including a cafeteria, theater, movie theater, grocery store, walk-in clinic, child-care center, hairdresser's salon, post office, telegraph, bank, gym, laundry, library, tennis court, 
and several dozen rooms for various activities (from pool-playing and target shooting to painting and orchestra rehearsals).

In the 1930s and 40s, about 800 House residents and an unspecified number of employees were evicted from their apartments and accused of various crimes. 344 residents are known to have been shot; the rest were sentenced to various forms of imprisonment.

This chapter deals with the residents' reactions to mass arrests and the puzzle of what kind of behavior was morally appropriate. Who was, under those circumstances, a "good person"?

\section{KOPSAVILKUMS}

Šis raksts ir autora grāmatas "Valdības nams: Krievijas revolūcijas sāga" saīsināta un nedaudz pārveidota versija, grāmata iznāca Prinstonas Universitātes apgādā 2017. gadā (Princeton University Press, 2017). Valdības nams, kas pēc Jurija Trifonova romāna ir plaši pazīstams arī kā Krastmalas nams, tika uzbūvēts Maskavas centrā pirmās piecgades laikā, to bija paredzēts izmantot kā padomju valdības locekḷu apartamentu kompleksu. Tas bija lielākais dzīvokḷu komplekss Eiropā ar 505 pilnībā apgādātiem apartamentiem un koplietošanas telpām - kafejnīcu, teātri, veikaliem, klīniku, bērnudārzu, frizētavu, pasta nodaḷu, telegrāfu, bankas nodaḷu, sporta zāli, veḷas mazgātavu, bibliotēku, tenisa kortu un vairākiem desmitiem telpu dažādām aktivitātēm, sākot no biljarda zālēm un telpām mērḳi šaušanai līdz gleznošanai un orḳestra mēǵinājumiem.

Pagājušā gadsimta 30. un 40. gados apmēram 800 nama iemītnieku un nenoskaidrots skaits darbinieku tika izraidīti no vinu apartamentiem un apsūdzēti dažādos noziegumos. 344 iemītnieki, cik zināms, tika sodīti ar nāvi nošaujot, pārējiem tika piespriests dažāda veida un ilguma ieslodzijums.

Šajā rakstā aplūkota nama iemītnieku reakcija uz masu arestiem un sarežgītais jautājums par to, kādi uzvedības veidi bija morāli pien,emami. Kurš šajos ekstraordinārajos apstākḷos varēja sevi saukt par labu cilvēku? 


\title{
Tūrisma organizācija Latvijas PSR: Latvijas republikāniskās tūrisma padomes darbība 20. gadsimta 60 . gados
}

\author{
Organisation of Tourism in Latvian SSR: Activity of \\ Republican Tourism Council of Latvia in 1960s ${ }^{1}$
}

\author{
Ilze Vaivode, Mg. hist. \\ Latvijas Universitātes Vēstures un filozofijas fakultāte \\ Aspazijas bulvāris 5, Rīga, LV-1050 \\ E-pasts: ilzevaivode@yahoo.com
}

PSRS tūrisms kḷuva par padomju identitātes un kopējās vēsturiskās atmiñas veicinātāju - tas bija îpaši svarīgi pēc Otrā pasaules kara, kad PSRS varā bija nonākušas vairākas valstis, arī Latvija. Drīz sākās tūrisma jomas atjaunošana, tika dibinātas tūrisma organizācijas, taču centieni izveidot centralizētu tūrisma organizāciju nebija sekmīgi. 60. gados notika būtiska tūrisma reorganizācija, un tādējādi šim mērḳim izdevās pietuvoties. Pētījuma mērḳis ir analizēt Latvijas tūrisma un ekskursiju pārvaldes un Latvijas republikāniskās tūrisma padomes darbību, nosakot to sasniegumus un trūkumus. Darbā skaidrota organizāciju struktūra un struktūrvienību mijiedarbība - tas veicina izpratni ne vien par tūrisma organizēšanu, bet arī par procesiem sabiedrībā Latvijas PSR.

Atslēgvārdi: tūrisms, Latvijas PSR, PSRS, Latvijas tūrisma un ekskursiju pārvalde, Latvijas republikāniskā tūrisma padome.

In the USSR, tourism played an important role in the promotion of Soviet identity and building of collective historical memory, which was necessary after the Second World War, when the USSR had occupied many countries, including Latvia. After the war, the reconstruction of tourism began, however, the attempt to establish a centralized organization was unsuccessful. In the 1960s, a major reorganization of tourism was implemented that led closer to the goal. This study aims to analyse the activities of the Administration of Tourism and Excursions of Latvia and Republican Tourism Council of Latvia. It explains the structure of these institutions and the interaction between units. This work contributes to awareness about the organization of tourism, and also the society of Latvian SSR in the 1960s.

Keywords: Tourism, Latvian SSR, USSR, Administration of Tourism and Excursions of Latvia, Republican Tourism Council of Latvia. 


\section{levads}

Loti liela nozīme ceḷošanai pieškirta ne tikai mūsdienu sabiedrībā - tūrisma nozare spēcīgi iespaido arī pasaules ekonomiku, nodrošinot būtisku daḷu no pasaules valstu iekšzemes kopprodukta un darbvietām. ${ }^{2}$ Tūrismam ir arī politiska nozīme - tas var veicināt integrācijas procesus un sadarbību dažāda mēroga reǵionos, kā arī var liecināt par divu valstu valdību attiecībām. ${ }^{3}$

Par tūrismu sauc darbības, kas saistìtas ar celıšanu un uzturēšanos ārpus pastāvīgās dzīvesvietas brīvā laika pavadīšanas, lietišķo darījumu kārtošanas vai citā nolūkā ne ilgāk kā vienu gadu. ${ }^{4}$ Tūrisma veidi atšķiras atkarībā no tūristu mērkia, pārvietošanās un plānošanas veida.

Padomju Krievijā, vēl izjūtot Pirmā pasaules kara un Krievijas Pilsonnu kara sekas, sākās pievēršanās tūrisma attīstībai - tūrisms tika pārvērsts par ideologijas nostiprināšanas līdzekli sabiedrībā. Tā attīstība bija neviendabīga, ar to nodarbojās daudzas un dažādas organizācijas ar atškirīgiem mērķiem, uzdevumiem un priekšstatiem. ${ }^{5}$ Kā min pētniece Jūlija Rostovskaja (Iuliia Rostovskaia), posmā no Padomju Krievijas dibināšanas līdz 1926. gadam tika radīti pirmie dzelzs priekškara aizmetni, padarot ārējo tūrismu pieejamu tikai noteiktām sabiedrības grupām un popularizējot iekšējo tūrismu plašākai sabiedrības dalaia. ${ }^{6}$ 20. gadu beigās un 30. gadu sākumā precīzāk tika izstrādāti padomju tūrisma pamatprincipi: tūrismam bija jākḷ ūst par "jaunā padomju cilvēka" audzināšanas veidu kolektīvisma garā. ${ }^{7}$ Turpmākajos gados centralizācija kḷuva arvien stingrāka, tūrisma nozarei nonākot Vissavienības arodbiedrību centrālās padomes (VACP) Tūrisma un ekskursiju pārvaldes pakḷautībā.

Latvijas teritorijā jau padomju okupācijas sākumā tūrisms tika izmantots kā padomju propagandas līdzeklis - tas tika iesaistîts 1940. gada Saeimas vēlēšanu aǵitācijas rakstos (par Latvijas darba tautas bloka atbalstī̌sanu). ${ }^{8}$ Pēc Latvijas inkorporācijas sākās tūrisma sovetizācija, ${ }^{9}$ kas pilnībā kḷuva iespējama vien pēc Otrā pasaules kara beigām. Kara rezultātā tūrisma infrastruktūra bija ievērojami cietusi, taču vēl kara pēdējā mēnesī tika pieñemts lēmums turpināt Tūrisma un ekskursiju pārvaldes darbību un atjaunot infrastruktūru.

Kā min PSRS kultūras vēstures speciāliste Ena Gorsača (Anne Gorsuch), pēc Otrā pasaules kara, kad valdijja škietama robežu brīvība, Padomju Savienības valdības ideju par tūrismu varēja raksturot ar vārdiem "nekur nav tik labi kā mājās" - padomju iedzīvotāji tika virzîti uz valsts iekšieni, tālāk no "bīstamajām robežām", tādējādi mazinot Rietumu ietekmi un cenšoties stiprināt padomju patriotisko identitāti. ${ }^{10}$

Latvijas PSR tūrisma organizācija izveidota 1946. gada aprīlī un ar mainīgiem nosaukumiem pastāvēja līdz 1990. gadam. Sākotnēji tās nosaukums bija VACP Tūrisma un ekskursiju pārvalde, 1951. gadā to pārdēvēja par VACP tūrisma un ekskursiju Latvijas pārvaldi. 1960. gadā - par Latvijas tūrisma un ekskursiju pārvaldi (LTEP), bet tā joprojām palika VACP pakḷautība. ${ }^{11}$ Tūrisms nepiedzìvoja uzplaukumu uzreiz pēc kara, taču PSRS tūrisma vēstures pētnieks Grigorijs Usikins (Grigorii Usykin) saskatīja situācijas uzlabošanos un tūrisma popularizēšanos jau 60. gadu sākumā, ${ }^{12}$ tāpēc tas izvēelēts arī kā darba hronologiskā ietvara sākums. 1962. gadā organizācija tika pārdēvēta par Latvijas republikānisko tūrisma padomi (LRTP), bet pēdējo reizi pārdēvēta un reorganizēta 1969. gadā par Latvijas republikānisko tūrisma un ekskursiju padomi, ${ }^{13}$ kas arī iezīmē šì pētijjuma hronologisko beigu robežu. Lìdz 1962. gadam ar tūrisma organizēšanu paralēli nodarbojās vairākas organizācijas, no kurām dala tika likvidētas, izveidojot LRTP, kas kluva par centrālo tūrisma jomas pārvaldītāju. 
Lai arī tūrisms mūsdienās kḷuvis par nozīmīgu tautsaimniecības dalu, ${ }^{14}$ tomēr tā vēsture Latvijas PSR ir mazāk pētīta salīdzinājumā ar Krievijas padomju perioda un Rietumvalstu 20. gadsimta tūrismu. Pētījuma mērkisis ir analizēt LTEP/LRTP darbību 20. gadsimta 60. gados, nosakot darbības sasniegumus un trūkumus. Tas sniedz ieskatu tūrisma attīstībā LTEP/LRTP darbības ietekmē, izmaiṇās organizācijā un tās struktūrā, veicina izpratni par tūrisma organizēšanas un infrastruktūras attīstību, kā arī Latvijas PSR tūrisma attīstības iederību kopējās Padomju Savienības tendencēs. Zināšanas par tūrisma vēsturi palīdz veidot pasaules uztveri, šĩ joma ir pazīstama visā pasaulē - tas ir starptautisks fenomens, ${ }^{15}$ kas vieno cilvēkus laikā un telpā, nenemot vērā atškikirības. Tūrisma pētniecība palīdz saskatīt arī ikdienišḳu aktivitāšu saikni un noškirtību no citiem politiskiem un ekonomiskiem procesiem pasaulē un konkrētās valstīs.

Rakstā izmantoti Latvijas Nacionālā arhīva Latvijas Valsts arhīva 1755. fondā pieejamie dokumenti - dažādu tūrisma organizāciju dokumenti un grāmatvedības materiāli. Izmantoti arī vairāki preses izdevumi, kuros atainotas tūrisma jomas aktualitātes, pētāmo organizāciju darbība un problēmas. Zinātniskajā literatūrā pētāmo organizāciju darbība apskatītajā periodā Latvijas PSR nav atainota, rakstā izmantoti padomju tūrisma pētnieka G. Usikina, periodiskās preses pētnieces J. Rostovskajas un PSRS kultūras vēstures speciālistes E. Gorsačas darbi. Ārzemju tūrismu Latvijas PSR ir pētijusi Ineta Lipša. ${ }^{16}$

\section{Latvijas tūrisma un ekskursiju pārvaldes darbība}

\section{Uzdevumi un pienākumi}

40. un 50. gados lielāko ieguldījumu tūrisma jomas attīstībā deva atsevišḳas sekcijas uzṇēmumu un organizāciju fizkultūras kolektīvos, bet 1960. gadā daḷa tūrisma organizēšanas uzdevumu tika pārvirzīti Latvijas tūrisma un ekskursiju pārvaldes pārzin̄ā, cerot uz ievērojamāku attīstību tieši virsorganizācijas - VACP - dēḷ, kurai bija pieejami lielāki materiālie līdzekḷi un vairāk darbinieku. ${ }^{17}$

LTEP darbība ilga vien divus gadus, organizācijas nosaukums grozīts bieži, taču darbības oficiālie uzdevumi bija visai nemainīgi: organizēt tūrismu un ekskursijas republikas robežās, tai skaitā propagandēt padomju ideologijas pamatnostādnes, iepazīstinot strādniekus ar padomju tautu vēsturi un kultūru, ekonomiku, geogrāfiju, dabas bagātībām, sagatavot tūrisma nozares darbiniekus, vadīt tūristu klubus, būvēt, uzturēt, vadīt un finansēt tūrisma infrastruktūru (viesnīcas, tūristu bāzes un patversmes, ekskursiju bāzes, inventāra nomas punktus, filiālsaimniecības u. tml.), ${ }^{18}$ organizēt ceḷojumus un ekskursijas, kā arī sagatavot tūristus nozīmītes "PSRS tūrists" saņemšanai, organizēt un realizēt konsultācijas par tūrisma un ekskursiju jautājumiem. ${ }^{19}$ 60. gadu sākumā īpaša uzmanība tika pievērsta tūrisma sekciju izveidei dažādās rūpnīcās un citās darbavietās, kā arī tūrisma sacensību organizācijai un līdz ar to - sekciju un klubu darbam un nozīmīšu ieguvēju skaitam. ${ }^{20}$ Nozīmīšu sistēmu jau 30. gadu beigās izveidoja VACP tūrisma un ekskursiju pārvalde, lai motivētu tūristus turpināt sevi fiziski attīstìt. ${ }^{21}$ Nozīmīti "PSRS tūrists" varēja saņemt jebkurš pilngadīgs pilsonis, kuram bija vismaz divu gadu pieredze tūrismā ar vismaz 2-3 izietiem noteiktas grūtības maršrutiem un kurš varēja pierādīt savas teorētiskās un praktiskās spējas pēc speciālas tūrisma programmas apgūšanas. ${ }^{22}$

Organizācijai bija jādarbojas pēc VACP noteiktā aprēḳina, tā saskaṇā ar likumu konkrētajā situācijā drīkstēja rīkoties patstāvīgi - izmantot tai pieškirtos īpašumus, 
savā vārdā slēgt līgumus un citus darījumus, iegūt jaunus īpašumus. ${ }^{23}$

Tiešā vadība bija jānodrošina VACP Centrālās tūrisma un ekskursiju pārvaldes ieceltajam organizācijas priekšniekam, kurš bija atbildīgs par tūrisma organizācijai uzdoto uzdevumu un plānu izpildi, ievērojot finanšu un saimniecisko lietu un vienošanos izpildi. Priekšniekam bija jāizstrādā un jāiesniedz saimniecības-finanšu plāns, jaunie celtniecības, paplašināšanās, organizācijas saimniecību un uznēmumu rekonstrukciju plāni, kapitālā remonta un atjaunošanas plāni, informācija par personālu un administratīvās pārvaldes izdevumiem. ${ }^{24}$ Viṇš bija atbildīgs par visām organizācijas pārvaldībā esošām materiālām vērtībām (lîdzekḷiem no pakḷautībā esošajām saimniecībām un uzṇēmumiem, kredītiem, bankas kontiem u. tml.). ${ }^{25}$

LTEP darbību ietekmēja jaunais padomju ideologiizācijas vilnis, kas sākās ar septingades plāna pien,emšanu 1959. gadā un nostiprinājās līdz ar pārstrādātās Komunistiskās partijas programmas pieņemšanu 1961. gadā. Kā min tiesību zinātnieks Rūdolfs Šlēzingers (Rudolf Schlesinger), partijas programmas bija ne tikai teorētiski koncepti, bet arī vieni no kanāliem, pa kuriem šî teorija var tikt îstenota praksē. ${ }^{26}$ Jaunajā programmā uzsvērta virzība uz komunismu kā cilvēces attīstības ceḷu un komunistiskās sabiedrības celšanu. Vēl lielāks uzsvars likts uz padomju tautību vienotības palielināšanu, kā arī izvairǐšanos no kodolkara. R. Šlēzingers to nosauca par virzīšanos uz komunistiskās sabiedrības attīstību miermīlīgas sāncensības laikā, ${ }^{27}$ ko var vērtēt kā atbilstošu aukstā kara detente periodam, ja neskaita Kubas raķešu krīzi vien gadu pēc programmas pieņemšanas. Saasinājums ASV un PSRS attiecībās vērojams arī pēc padomju valdības pastiprinātas uzmanības pievēršanas t. s. masu aizsardzības darbam, kā rezultātā arī LTEP darbiniekiem bija jāpiedalās civilās aizsardzības programmā, iegūstot GPA ${ }^{28}$ otro pakāpi. ${ }^{29}$

Šì programma noteica LTEP darbības mērḳus un tūrisma pasākumu ideologiskos uzsvarus - Krievijas Pilsoṇu kara un Otrā pasaules kara Austrumu fronte $\bar{e}^{30}$ heroizēšana, masu tūrisma un ekskursiju kā patriotiskās audzināšanas attīstǐšana. ${ }^{31}$ Viens no partijas pamatuzdevumiem bija panākt pilnīgu kopību, sociālo viendabību un draudzību starp Padomju Savienības tautām. Arī šajā gadījumā tūrisms kḷuva par šī mērḳa sasniegšanas metodi. LTEP bija jāpadara tūrisms par masveidīgu, aktīvu brīvā laika pavadīšanas veidu, kas pieejams jebkura vecuma un fiziskās sagatavotības cilvēkam. ${ }^{32}$

Saistībā ar partijas programmu jāpievērš uzmanība tūrisma saiknei ar valsts ekonomiku. Šajā laika posmā pēc N̦ikitas Hruščova (Nikita Khrushchev) iniciatīvas izstrādātais septingades plāns bija tik ambiciozs, ka izrādījās nesasniedzams. Tūrisms bija atkarīgs no ražošanas un celtniecības jomām - nepieciešamā apgéerba un inventāra ražošanas, tūrisma infrastruktūras būvēšanas dažādu bāzu, staciju, satiksmes ceḷu un līdzekḷu formā. Ja tūrisma organizācijai trūka resursu, tā nevarēja izpildīt arī savus darba plānus. Grūtības darba plāna izpildīšanā var saskatīt Latvijas tūrisma un ekskursiju pārvaldes gada atskaitēs, kurās atsevišķi apskatīts pašas pārvaldes un atsevišḳu tūristu bāzu darbs. 1960. gadā lielākā daḷa mērḳu netika sasniegta, netika apkalpots pietiekams skaits tūristu ar ceḷazīmēm, bija pārsniegta tūristu apkalpošanas pašizmaksa, kā dēḷ 1960. gadā pārvaldes parādi bija palielinājušies par 27 tūkstošiem rubḷu. ${ }^{33}$ Lìdzīgas grūtības vērojamas arī 1961. gadā. ${ }^{34}$

Liela uzmanība tika pievērsta kvalifikācijas jautājumiem - ne vien darbinieku, bet arī tūristu vidū. Cenšoties palielināt tūristu skaitu, parādījās ievērojamas tūrisma drošības problēmas, jo jaunie tūristi mēdza, 
piemēram, doties pārgājienos, īsti neizprotot pareizu tūrisma tehniku. Kā liecina raksti preses izdevumos, radās nelaimes gadījumi, kurus nenovērsa pat šo tūristu škiietamā sagatavotība (nozīmītes "PSRS tūrists", nokārtoti sporta klases normatīvi). ${ }^{35}$ LTEP bija jārealizē virkne preventīvu pasākumu, piemēram, katrai tūristu grupai jāpiešḳir apmācīti instruktori, jāorganizē drošības instruktāžas, ${ }^{36}$ grupām jānodrošina medicīniskais personāls. ${ }^{37}$

LTEP darbības laikā sākās regulāra ekskursiju vadītāju apmācīšana un darba novērtēšana. LTEP paklautībā tika izveidota Atestācijas un kvalifikācijas komisija, kurai bija jānosaka vadītāju sagatavotība un jāpieškiir attiecīgā kvalifikācija. Tika nolemts, ka visiem pirmoreiz ekskursiju darbā pieņemtajiem ekskursiju vadītājiem ir jāiziet atestācija, kur piešķīra kvalifikāciju ar trīs gadus derīgu apliecinājumu, ${ }^{38}$ ko apstiprināja Latvijas Republikāniskā arodbiedrību padome, Latvijas PSR Kultūras ministrija un Rīgas pilsētas darbal̦aužu deputātu padomes izpildkomiteja. 1961. gada nogalē tika lemts par stingrāku ekskursiju vadītāju pašizpausmju ierobežošanu ekskursiju laikā - pārvaldei bija jāizveido kontroles teksti un ieteicamās literatūras saraksts katram maršrutam. ${ }^{39}$ Kvalifikācijas celšanas nolūkos uz kursiem un kopsapulcēm Maskavā un L̦eņingradā regulāri devās pārvaldes priekšnieks, vecākais instruktors, grāmatvedis, kā arī tūristu un ekskursiju bāzu direktori un atsevišḳi instruktori. ${ }^{40}$

\section{Struktūrvienības}

LTEP pārziñā bija vien pāris tūristu bāzes, lai gan Latvijas PSR teritorijā bija lielāks skaits tūristu bāzu. Daḷa no tām atradās Vissavienības L Leñina komunistiskās jaunatnes savienības (VḶKS) ${ }^{41}$ un Latvijas PSR Izglīiības ministrijas Republikāniskās bērnu ekskursiju un tūrisma stacijas pārvaldībā. ${ }^{42}$
1961. gadā Latvijas tūrisma un ekskursiju pārvaldes pakḷautībā tika izveidota Rīgas ekskursiju bāze, kurai bija jāorganizē ekskursijas pa republiku (ar uzsvaru uz brīvdienu tūrismu), autobusu, vilcienu un tvaikoṇu īrēšana tūrisma un ekskursiju pasākumiem, jānodrošina tūrisma un ekskursiju reklamēšana, plakātu, afišu un prospektu izdošana saskaṇā ar finanšu plānu. ${ }^{43}$ Rīgas tūristu bāzei bija jāpiešḳir Rīgas ekskursiju bāzei inventārs, naudas līdzekḷi, nepieciešamie dokumenti, kā arī vairāki štata darbinieki.

Atsaucoties uz 1961. gada Padomju Savienības Komunistiskās partijas 22. kongresa un Latvijas Komunistiskās partijas 18. kongresa lēmumiem, Rīgas ekskursiju bāze plaši izvērsa tūrisma attīstību Rīgā. Bāzei bija pavēlēts izstrādāt 12 jaunu maršrutu projektus pa Rīgu, kuros jāpievērš uzmanība republikas strādnieku sasniegumu propagandēšanai, padomju varas gados īstenotajai Rīgas attīstībai rūpniecības, dzīvojamās platības, zinātnes, kultūras un sadzīves jomās, kā arī plānotajai Rīgas attīstišanai "komunisma celtniecības laikā". ${ }^{44}$ 1962. gada maijā jau bija izveidoti septiņi autobusu maršruti, septiņi pārgājienu maršruti, divi tvaikoṇu maršruti, iekḷaujot revolucionāru pieminekḷu vietas, revolūcijas notikumu vietas, Brāḷu kapus, rūpniecības objektus. Kāds maršruts tika veltīts "komjauniešu cīn,ai par padomju varu Latvijā", cits - Rainim, vēl cits - literatūrai, teātrim un arhitektūrai. Ik mēnesi bija jāveic kvalitātes kontrole, jānoklausās gidu stāstījums, nepiel̦aujot neatbilstošas informācijas izplatī̌sanu, ${ }^{45}$ tātad vērojama maršrutu ideoloğizācija.

Pārvalde pieškīra bāzēm līdzekḷus dažādām vajadzībām, piemēram, propagandas darbam, metodiskajam darbam un kadru sagatavošanai. Pieškirtās summas katrai bāzei atškīrās. 1961. gadā vislielākā summa piešķirta Rīgas ekskursiju bāzei (505 rublii), bet mazākā - Rīgas tūristu bāzei un 
Strēlnieku tūristu bāzei (katrai 50 rubḷi). ${ }^{46}$ Ekskursiju vadītāju sagatavošana tika intensīvi plānota, un pārvalde veiksmīgi izstrādāja konkrētu metodiskā darba uzlabošanas plānu, kura rezultātā tika organizēti 10 dienu semināri ekskursiju vadītājiem.

Kā minēts iepriekš, LTEP pārvaldītās tūristu bāzes saskārās ar grūtībām, izpildot darba plānu, - liela daḷa mērḳu palika neīstenota. Mērḳi bija nosprausti divās kategorijās - plānveida tūristu apkalpošana un pašdarbības tūristu apkalpošana. 1960. gadā vissliktāk plānu realizēja tikai tajā gadā pabeigtā Kandavas tūristu bāze, bet vislabāk - Siguldas tūristu bāze. Tikai Rīgas un Siguldas tūristu bāzes bija izpildījušas un pat pārpildījušas noteikto plānu, lai gan arī tikai vienā no kategorijām pašdarbības tūristu apkalpošanā. Tāpat tika pārsniegta plānotā tūristu apkalpošanas pašizmaksa - Rìgas tūristu bāzē par 86,1 tūkstoti, bet Strēlnieku tūristu bāzē par 22,1 tūkstoti rubliu. ${ }^{47}$

LTEP centās kontrolēt arī atsevišksus procesus saistībā ar tūristu bāzu darbiniekiem. Lai gan bāzu darbinieki bija arī pārvaldes štata darbinieki, tomēr bāzu darbiniekus atlaida bāzu direktori. Izmaiṇas šajā procesā notika 1961. gada beigās, kad LTEP tika piešḳirtas pilnvaras atlaist bāzes ekskursiju vadītāju tieši, bez bāzes vadītāja starpniecības $^{48}$ - tas norāda uz ekskursiju vadītāju darba kontroles pastiprināšanu. Kā liela problēma aprakstīta ekskursiju vadītāju pārstrādāšanās vasaras mēnešos. ${ }^{49}$

\section{Latvijas republikāniskās tūrisma padomes darbiba}

\section{Nodaḷas, komisijas un sekcijas}

1962. gada nogalē LRTP priekšsēdētājs Arnolds Ūdris informēja sabiedrību par Latvijas republikāniskās ekskursiju un tūrisma pārvaldes pārdēvēšanu par Latvijas republikānisko tūrisma padomi, intervijā laikrakstam "Cīn,a” norādot, ka iepriekšējā pārvalde bijusi lielākoties saimnieciska organizācija, bet jaunā padome nosaukta par koleǵiālu orgānu, kas izveidots tieši masu darba uzlabošanai un veicināšanai. ${ }^{50}$

LTEP/LRTP un to priekšgājēju štata apmēri bijuši samērā nelieli. Apskatāmā perioda sākumā pārvaldes štats sastāvēja no sešiem cilvēkiem - tie bija pārvaldes priekšnieks, vecākais instruktors, instruktors, galvenais grāmatvedis, grāmatvedis-kasieris, sekretārs-mašīnrakstītājs. Šāds bija pārvaldes oficiālais sastāvs līdz pat 1964. gadam, kad pienēema darbā arī inženieri. To var saistīt ar organizācijas pieaugošajām celtniecības vajadzībām - tika gan projektētas un būvētas jaunas tūristu un ekskursiju bāzes, gan paplašinātas un atjaunotas jau esošās. 1965. gadā LRTP štats tika ievērojami paplašināts, sasniedzot 12 cilvēku kolektīvu. ${ }^{51}$ 1966. gadā kolektīvam pievienojās divi instruktori, ${ }^{52}$ 1967. gadā bija plānots vēl viens darbinieks - galvenā grāmatveža vietnieks, taču gada gaitā pievienojās divi jauni darbinieki - vēl viens inženieris un grāmatvedis. ${ }^{53}$ Padome palika šādā 17 cilvēku sastāvā līdz 60. gadu beigām, tātad apskatītajā periodā organizācijas darbinieku skaits gandrīz trīskāršojās.

Štatu sarakstā norādīts padomes sadalijums vairākās nodaḷās - masu tūrisma, tūrisma maršrutu, bāzu celtniecības un ekspluatācijas, plānošanas un finanšu nodaḷā, taču par to darbu LRTP dokumentos informācija nav atainota, fiksētas tikai atsevišḳ personu darbības (komandējumi, atvaḷinājumi, dalība citās nodaḷās, komisijās u. tml.).

17 cilvēki - šis skaitlis neatspoguḷo patieso pārvaldes aktīvistu apjomu, jo daḷu no tiem uzskaitīja atsevišķi, piemēram, tūristu bāzu darbiniekus, vai arī tie vispār neparādās organizācijas štatu sarakstos. Tomēr organizācijas dokumenti apliecina viņu aktīvo dalību tūrisma veicināšanā, lai arī viṇi pārstāv citas organizācijas, viṇiem 
ir cita darbavieta un nodarbošanās, taču viņi lielākoties ir arī šo pašu organizāciju tūrisma sekciju vai pilsētu/rajonu tūristu klubu pārstāvji, lai gan sākotnēji tas uzskaitēs netika minēts. Iespējams, ar to var pamatot iemeslu, kāpēc LRTP priekšsēdētājs to nosauca, kā jau pieminēts, par koleg̣iālu orgānu.

LRTP prezidija pirmās sēdes atskaitē minētas padomes piecas jaunās komisijas. Komisijas bija līdzīgas vēsturiskajā izziṇā norādītajām nodaḷām, taču specifiskākas.

Plānošanas un ekspluatācijas komisija izstrādāja saimniecības-finanšu plānu tūristu un ekskursiju bāzēm un pašai padomei, kā arī plānoja tūristu bāzu kapitālieguldījumus un labiekārtošanu. ${ }^{54}$ Tai bija jāpārbauda apkalpošanas kvalitāte tūristu un ekskursiju bāzēs, to gatavība sezonu sākumā, ${ }^{55}$ kā arī jākontrolē bāzu celtniecība. ${ }^{56}$

Maršrutu un kvalifikācijas komisija plānoja maršrutu tūrismu (kur persona noteiktā laikā jebkurā pārvietošanās veidā veic iepriekš ieplānoto maršrutu pa dažādiem geogrāfiskiem punktiem), ${ }^{57}$ uzskaitīja sporta klasi ieguvušās personas, izskatīja un apstiprināja maršrutus republikas teritorijā, pieņēma un uzraudzīja nozīmīšu pieškiiršanas kārtību, rīkoja seminārus rajonu un pilsētu maršrutu komisiju darbiniekiem. ${ }^{58}$ Šìs komisijas piešķirtās nozīmītes, piemēram, "Padomju tūrists", it kā tika radītas, lai motivētu cilvēkus turpināt fiziski attīstīt sevi, taču, aplūkojot tās normatīvus, var secināt, ka tā bijusi arī rūpēšanās par tūristu drošību un veselību, bet tūrista nosaukums vismaz teorētiski varēja radīt zināmu kopības sajūtu dažādu republiku un tautību tūristiem. 60. gados nozìmīšu sistēmu paplašināja - izveidoja nozīmīti "LRTP tūrists", kuras iegūšana kḷuva par vienu no normatīviem, kas jāizpilda, lai iegūtu nākamās, "PSRS tūrists" nozīmītei izveidotās pakāpes (III, II un I), bet tālākais sasniegums bija kḷūt par PSRS tūrisma meistara kandidātu, tad - par PSRS tūrisma meistaru. ${ }^{59}$ 1967. gada nogalē uzsākta jaunas nozīmītes izveide - "Latvijas PSR tūrists". ${ }^{60}$ Sadarbībā ar Masu sporta veidu sekciju šì komisija organizēja konsultācijas tūristiem par dažādiem tūrisma veidiem. ${ }^{61} 1963$. gada nogalē šĩs komisijas sastāvs tika paplašināts, piebiedrojoties auto-moto tūrisma pārstāvjiem. ${ }^{62}$

Atestācijas un metodiskā darba komisija (vēlāk - Kadru un atestācijas darba komisija) ${ }^{63}$ pieškīira kvalifikācijas, veica uzskaiti par instruktoru un tiesnešu dalību kursos un semināros, regulēja pārtestēšanu, ${ }^{64}$ veidoja mācību plānus, ieteicamās literatūras sarakstus, plānoja maršrutus Rīgā un tās apkaimē vidējās un vecākās paaudzes cilvēkiem, piedalījās un organizēja tūristu vakarus, sastādīja konkursu nolikumus. ${ }^{65}$ Dokumentācijā vērojama šīs komisijas ciešā sadarbība ar Maršrutu un kvalifikācijas komisiju un Rīgas pilsētas tūristu klubu, kur komisijas pārstāvjiem bija jāsniedz konsultācijas. ${ }^{66}$

Masu tūrisma darba komisija (vēlāk Organizatoriskā-masu komisija) bija atbildīga par jaunu tūrisma kadru sagatavošanas plāna un masu pasākumu plāna izveidi, par LRTP drukāto izdevumu saraksta uzturēšanu, svarīgāko tūrisma materiālu tulkošanu latviešu valodā un izplatīšanu, ${ }^{67}$ par tūristu konferenču organizēšanu, tūrisma sekciju veidošanās veicināšanu fizkultūras kolektīvos, ${ }^{68}$ par tūristu klubu nolikuma sastādīšanu un papildināšanu, kā arī pilsētu un/vai rajonu tūristu klubu izveidi (1963. gadā tapa pirmie pieci klubi Rīgā, Liepājā, Daugavpilī, Jelgavā un Ventspilī, ${ }^{69}$ 1967. gadā - jau $30^{70}$ ). Svarīgākais pasākums, ko organizēja šì komisija, bija Latvijas un Baltijas tūristu ikgadējie salidojumi.

Propagandas un aǵitācijas komisija bija atbildīga par visiem darbiem saistībā ar medijiem un publicitāti - par tūrisma rubrikām laikrakstos, radio un televīzijā, tai bija jāsastāda publicējamās literatūras, 
plakātu un prospektu piedāvājumi, jāveido informatīvie stendi Latvijas PSR lielākajās pilsētās. 1963. gadā tika uzsākti mēginājumi organizēt mediju iestādēs savas arrpusštata nodal̦as, ${ }^{71}$ taču šì uzdevuma izpilde aizkavējās. ${ }^{72}$ Uzlabojumu publicitātes jautājumos var saskatīt 1964. gada otrajā pusē, kad šì komisija jau veidoja masu tūrisma propagandas plānu sadarbībā ar dažādiem medijiem. ${ }^{73}$

LRTP prezidija pirmajā sēdē tika dibinātas arī piecas jaunas sekcijas.

Telšu pilsētiņu tūrisma un veselības nostiprināšanas (Atpūtas nometnuu) sekcija sadarbojās ar Atestācijas un metodiskā darba komisiju un dažādām Rīgas organizācijām un uzṇēmumiem, lai organizētu masu tūrisma pasākumus telšu pilsētiṇās, tai bija arī jāpievēršas pastāvīgai tūrisma propagandēšanai medijos. ${ }^{74}$ Sekcija sadarbojās ar Latvijas PSR Ministru padomi, cenšoties iegūt zemes îpašumus, kur būvēt šīs nometnes, ${ }^{75}$ tādēl, 60. gados arvien mazāk tūristu bāzu telpu bija jāīrē - LRTP spēja iegūt tās savā īpašumā. Vairumā gadījumu sekcijas darbs vērtēts kā l̦oti produktīvs, tas ietvēra idejiski politiskās, audzinošās un sporta aktivitātes (tikšanās ar dažādu profesiju pārstāvjiem, lekcijas, referātu lasījumi, sarunas, sporta sacensības, pārgājieni). LRTP arī uzsvēra, ka ne visās nometnēs padarītais darbs vērtējams kā labs. Konstatēti atsevišḳi gadījumi, kad darbs vispār nav veikts. ${ }^{76}$ Tātad, tāpat kā iepriekšejos periodos, darbs bija loti atkarīgs no personu iniciatīvas un vēlmes darboties. Šādās atpūtas nometnēs arī varēja nokārtot sporta klases, saṇemt nozīmītes un iegūt tiesneša vai instruktora kvalifikāciju - viņi tika nodarbināti tuvējās mežsaimniecībās, kolhozos un sovhozos: tas tikai paspilgtina un parāda, kā realitātē izpaudās padomju presē bieži izteiktā doma, ka fizisks darbs svaigā gaisā ir vislabākā atpūta. ${ }^{77}$

Bērnu un skolu (Bērnu un jaunatnes) tūrisma sekcijas darbinieki pēc profesijas bija ḷoti atbilstoši šĩs sekcijas darba specifikai. To vadīja Republikāniskās bērnu ekskursiju un tūrisma stacijas direktore, tajā darbojās Pionieru pils un Skolotāju nama tūristu kluba pārstāvis, Rēzeknes rajona tautas izglìtības nodaḷas darbinieks, kā arī vairāki vidusskolas skolotāji. ${ }^{78}$ Šì sekcija organizēja un vadīja dažādus konkursus tūrisma veicināšanai, pionieru vadītāju seminārus, jauno tūristu salidojumus, jauno tūristu vakarus, kā arī veica sistemātisku darbu nozīmnieku "PSRS tūrists" un "Jaunais pionieris" sagatavošanā. ${ }^{79}$ Vērienīgākie masu pasākumi bija saistīti ar ideologiskajiem svētkiem, piemēram, 1963. gadā tā organizēja novadpētniecības ekspedīciju, kas bija veltīta Padomju Savienības Komunistiskās partijas sešdesmitgadei, 1969. gadā - Lenina 100. dzimšanas dienai. ${ }^{80}$ Atkarībā no svinamajām dienām šai sekcijai arī bija jānosaka svarīgākie skolās apskatāmie novadpētniecības jautājumi. ${ }^{81}$ 1966. gadā tika uzsākta virzība uz tālāku vienotības nostiprināšanu bērnu tūrisma jautājumos, kā rezultātā, apvienojot LRTP, Latvijas PSR Izglītības ministrijas un vairāku citu organizāciju spēkus, tika izveidota Republikāniskā bērnu un jaunatnes tūrisma metodiskā padome, lai uzlabotu situāciju ar tūrismu vispārizglītojošās skolās, un tā aizvietoja šo sekciju. ${ }^{82}$

Masu tūrisma veidu sekcija bija sadalìta trīs apakšsekcijās pēc tūrisma veida: ūdens tūrisms, kājnieku un slēpošanas tūrisms, kalnu un taigas tūrisms. Katras apakšsekcijas pienākumos ietilpa pasākumu organizēšana, piemēram, tūristu vai atskaites vakaru organizācija, semināru organizēšana grupu vadītājiem, praktisko nodarbību organizēšana tūristiem iesācējiem, dažādu uzskaišu sastādīšana (republikas fizkultūras kolektīvu, tūristu uzskaite, pārgājienu/maršrutu kartotēkas), kā arī tūristu informēšana par pakāpju iegūšanu. ${ }^{83}$ Apakšsekcijām nācās sadarboties ar Atestācijas un metodiskā darba komisiju, 
strādājot pie jauno instruktoru apmācībām, kā arī jāpalīdz Rīgas pilsētas tūristu bāzei izvēlēties pasniedzējus apmācībām. ${ }^{84}$ To pienākumos ietilpa arī pētniecības darbs izzināt atšķirīgus Latvijas PSR apvidus, lai atrastu piemērotas vietas dažādu tūrisma veidu maršrutiem. ${ }^{85}$ Ūdens tūrisma sekcija nodarbojās ar savai specifikai atbilstošiem uzdevumiem, piemēram, tai bija jāizveido Latvijas upju klasifikācija, jāizstrādā atbilstoša treniṇprogramma, kā arī peldēšanas prasmju pārbaudes noteikumi. ${ }^{86}$ İpaši jāizcel̦ Kalnu un taigas tūrisma apakšsekcija, kurai bija visvairāk darba uzdevumu - tas saistāms ar Latvijas PSR iedzīvotāju pieredzes trūkumu šajā jomā. Liels uzsvars tika likts uz pieredzes apmaiṇu ar šādām sekcijām citās republikās, specifisku treniṇu organizēšanu ar nakšn,ošanu ziemas apstākḷos un ar alpīnistiem, alpīnisma teorijas apgūšanu, fizisko un teorētisko normatīvu izstrādi. Būtībā tika veicināta tūristu drošība, tai skaitā analizējot nelaimes gadījumus. ${ }^{87}$ 1963. gada nogalē Masu tūrisma veidu sekcija tika reorganizēta un apakšsekcijas kḷuva par patstāvīgām sekcijām, jo iepriekšējais iedalījums izrādījās neefektīvs, ${ }^{88}$ bet pienākumus gan tas nemainīja.

Autotūrisma (Auto-moto tūrisma) sekcija organizēja un vadīja sekcijas darbu, sastādīja un izplatīja Latvijas PSR auto-moto maršrutu brošūras, nodrošināja motociklu rezerves detalı u pieejamību. ${ }^{89}$ Šìs sekcijas darbību apliecinošie materiāli parādās, sākot ar 1963. gadu. Kopumā tās pienākumi atbilda citu tūrisma veidu sekciju darbam, tai skaitā sacensību ${ }^{90}$ un konkursu organizēšana ("labākais auto-moto tūrists" u. c.). ${ }^{91}$

Arī Ekskursiju darba sekcijas darbību apliecinošie materiāli parādās 1963. gadā. Šai sekcijai bija pakḷauta Rīgas ekskursiju bāze un tās filiāle Jelgavā, kas izveidota 1964. gadā. Šì sekcija izstrādāja šo bāzu maršrutus, izvēlējās un sagatavoja darbiniekus, organizējot seminārus gidu kvalifikācijas uzlabošanai, veidoja un pārbaudīja ekskursiju kontroles tekstus, ${ }^{92}$ sagaidīja tūristu vilcienus no citām PSRS republikām, rīkoja fotokonkursus un atskaites vakarus, organizēja ceḷojumus komunistiskā darba brigādēm. ${ }^{93}$ Viens no spilgtākajiem piemēriem gidu sagatavošanā 60 . gados saistīts ar zinātniski ateistisko propagandu baznīcu arhitektūras pieminekḷu ekskursijās. ${ }^{94}$ Lēmumu par šādu apmācību pieņēma Centrālās tūrisma padomes Ekskursiju darba komisija. Tika uzsvērts, ka viss, kas saistīts ar baznīcu, jāparāda kā mākslas un cilvēces attīstības posms, ko radījusi tauta, nevis baznīca kā organizācija, tādējādi cenšoties atṇemt baznīcām svētuma aspektu..$^{95}$ Minēti arī konkrēti pozitīvie piemēri no ekskursijām Latvijas PSR, piemēram, ekskursijā Doma baznīcā gidiem bija jāstāsta par baznīcas kontrrevolucionāro lomu nacistiskās okupācijas laikā. Tāpat gidiem bija jāizcel sociālā nevienlīdzība un reliǵisko svētku un tradīciju audzinošā nozīme, kamēr, aprakstot jaunos padomju svētkus un tradīcijas, audzinošo raksturu pieminēt nedrīkstēja. ${ }^{96}$

Šo sekciju un komisiju vadītāji kopā ar LRTP priekšsēdētāju veidoja LRTP prezidiju, kas apstiprināja lēmumus, darba plānus, izdevumu tāmes, atskaites, nolikumus ${ }^{97}$ un būtībā sabiedrības priekšā atbildēja par tūrisma attīstības jautājumiem. Proti, kad nenotika pietiekami ātra izaugsme, tieši prezidijs saṇēma pārmetumus preses rakstos. ${ }^{98}$ Nodaḷas, komisijas un sekcijas kopīgi organizēja tūristu bāzes un ekskursiju bāzes (60. gadu otrajā pusē pārveidotas sākotnēji par ekskursiju birojiem, bet drīz pēc tam par ekskursiju un cel̦ojumu birojiem), arī pilsētu un/vai rajonu tūristu klubus.

Komisijas, sekcijas un tūristu klubi savstarpēji sadarbojās, arī organizējot apmācības un masu pasākumus. Padomei bija jāinformē savas struktūrvienības par Centrālās tūrisma padomes lēmumiem. Katrā tūristu klubā bija izveidotas savas komisijas saskaṇā ar LRTP komisiju 
struktūru, kurām tās atskaitījās. LRTP komisijas arī palīdzēja tūristu klubu komisijām dažādos jautājumos.

\section{Bāzes un biroji}

Ekskursijas, pārgājienus un citas tūrisma aktivitātes organizēja tūristu un ekskursiju bāzes: iepriekšējo tūrisma organizāciju izveidotās Rīgas un Siguldas tūristu bāzes (1955), Strēlnieku tūristu bāze (1958), Kandavas tūristu bāze (1960), Rīgas ekskursiju bāze (1961) un pašas LRTP veidotās - Vaivaru tūristu bāze (1964) un Rīgas ekskursiju bāzes filiāle Jelgavā (1964) u. c. ${ }^{99}$ 60. gados LRTP paplašināja arī tūristu bāzu tîklu - no trīs tūrisma bāzēm ar kopumā 350 vietām 1960. gadā ${ }^{100}$ līdz piecām ar 1057 vietām 1969. gadā, ${ }^{101}$ samazinot īrēto tūristu bāzu skaitu attiecīgi no trīs ar 399 vietām ${ }^{102}$ lìdz vienai ar 100 vietām. ${ }^{103} 1965$. gada nogalē tika pieņemts lēmums piešķirt finansējumu vairāku jaunu tūristu bāzu izbūvei Alūksnē un Sauleskalnā, 1966. gadā sāka projektēt tūristu bāzes "Usma", "Ogre", "Ërglì" un "Rīgas Jūrmala", kā arī paātrināt jau iesāktā projekta izstrādi bāzei "Ezernieki". ${ }^{104}$ Bieži bāzu celtniecība ieilga darbinieku nolaidības vai resursu trūkuma dēḷ. Gandrīz visas iepriekš minētās bāzes arī 1969. gadā bija projektēšanas stadijā, ${ }^{105}$ un to celtniecību atlika uz 70. gadiem, kad bija plānota vērienīga bāzu tîkla paplašināšana un trīs tūrisma joslu izveidošana Latvijas PSR teritorijā. ${ }^{106}$

60. gados palielinājās tūristu un ekskursiju bāzēs nodarbināto personu skaits. Dekādes sākumā bija nodarbinātas 126 personas, ${ }^{107}$ bet 1969. gadā jau 218. ${ }^{108}$ Nodarbināto skaita palielināšanās nebija lineāra - atsevišḳos gados vērojama skaita samazināšanās.

Organizējot tūristu pasākumus, padome mēdza piesaistīt bāzu darbiniekus un uz bāzu rīkotajiem pasākumiem sūtīt pārvaldes darbiniekus. Padomes instruktori regulāri tika sūtīti uz tūristu bāzēm dažādos uzdevumos, fiksēti precīzi uzdevumi, citkārt - vispārināti, piemēram, "sniegt tūrisma - ekskursiju palidzību". ${ }^{109}$ Instruktori tika izmantoti kā papildpersonāls bāzēs, kad grupu skaita dēḷ ar bāzu darbiniekiem nepietika. ${ }^{110}$

Uz bāzēm tika sūtīti ne vien instruktori, bet arī grāmatveži, lai veiktu bāzu dokumentācijas revīziju. ${ }^{111}$ Gandrīz katrā revīzijā konstatēti vairāki pārkāpumi, un šo situāciju neizdevās labot līdz pat apskatāmā perioda beigām. ${ }^{112}$

Lai stimulētu darbu, arī tūristu bāzu ietvaros tika organizēta sociālistiskā sacensība (katras profesijas pārstāvjiem). 60. gados darbiniekus biežāk apbalvoja ar diplomiem, labākos izcēla uz goda dēḷiem, arī bāzes darbs vispār bija pakārtots ideologisisajiem svētkiem. ${ }^{113}$

Dokumentācijā parādās tādi darbības trūkumi kā nepietiekama gatavība noteiktiem pasākumiem. Piemēram, 1964. gadā Rīgas ekskursiju bāze san̄ēma pārmetumus no LRTP par to, ka nav gatava Latvijas PSR $^{114}$ un Oktobra revolūcijas gadadienu svinībām. ${ }^{115}$ LRTP turpināja atgādināt bāzu direktoriem par viņu atbildību situācijas kontrolēšanā, taču tādi gadījumi turpinājās. ${ }^{116}$ Par bezatbildību pārmetumi vairākkārt izteikti Rīgas ekskursiju bāzei, ipaši pēc direktora kabineta apzagšanas 1964. gada septembrī. ${ }^{117}$

Avotos parādās l,oti atšķirīga statistika par bāzu apkalpoto tūristu skaitu, tas, iespējams, saistāms ar nepareizu vienību nolasīšanu no atskaitēm vai to nepārveidošanu. Kopumā reālistiskākais uzskaitījums varētu būt šāds: 1962. gadā tūristu bāzes kopumā apmeklēja 14 tūkstoši cilvēku un ekskursijās piedalījās 184 tūkstoši, ${ }^{118}$ bet 1969. gadā Latvijas tūrisma bāzes apmeklēja vairāk nekā 10 tūkstoši tūristu, kas ceḷoja pa vissavienības maršrutiem, 14 tūkstoši - pa vietējiem, un 65 tūkstoši - pa individuāliem maršrutiem, bet 700 tūkstoši 
devās ekskursijās. ${ }^{119}$ Šie skaitḷi parāda visai ievērojamu izaugsmi.

1965. gadā tika izveidots Rīgas pilsētas ekskursiju birojs ${ }^{120}$ (tajā pašā dienā pārsaukts par Rīgas pilsētas ceḷojumu un ekskursiju biroju), ${ }^{121}$ tika dibināts arī Jūrmalas ekskursiju birojs un likvidētas attiecīgo pilsētu ekskursiju bāzes. ${ }^{122}$ Biroju uzdevums bija apkalpot strādnieku ekskursijas, ekskursiju laikā propagandēt padomju varas iestāžu lēmumus, kā arī iepazīstināt sabiedrību ar padomju valsts vēsturi un dabas bagātībām. Tātad būtībā biroju darbības mērḳi sakrita ar ekskursiju bāzu mērķiem un uzdevumiem (organizēt tūrisma pasākumus, izstrādāt maršrutus), ar struktūru un trūkumiem. Katrā ekskursiju birojā bija ekskursiju nodaḷa, cel̦ojumu nodal̦a, plānošanas un finanšu nodaḷa, ceḷazìmju realizācijas nodaḷa un metodiskā nodaḷa. ${ }^{123}$

Desmitgades sākumā nepietika apmācītu darbinieku, ${ }^{124}$ taču 1968. gadā situācija bija uzlabojusies, un gidi ne vien piedalījās speciālajās lekcijās, bet lielākā daḷa arī bija ieguvuši augstāko izglītību vēsturē un filozofijā, daḷai bija tehniskā augstākā izglītība, bet pārējie bija šādu izglītības iestāžu studenti, kā arī visi bija izgājuši atestāciju. ${ }^{125}$

Bāzu un biroju darbi lielākoties ir l,oti birokratizēti un atspogulo tikai konkrêtus faktus, tomēr tūristu plēnumu materiālos var saskatīt dažas liecības par organizāciju savstarpējām attiecībām. 1968. gada tūristu plēnumā izvērsās diskusija par Rīgas un Jūrmalas ekskursiju biroju attiecībām, kas nosauktas par neveselīgām un greizsirdības pilnām. ${ }^{126}$ Daḷa uzskatīja, ka pie šī saasinājuma ir vainojama LRTP, kas it kā ierobežojusi Jūrmalas ekskursiju biroju, lai atbalstītu Rīgas ekskursiju biroja plānus. Arī Rīgas ekskursiju biroja pārstāvji izteica pretenzijas pret LRTP par nepietiekamu biroja nodrošināšanu ar mēbelēm un telpu remontu (līdzīgi arī Daugavpils ekskursiju birojāā $\left.{ }^{127}\right) .{ }^{128}$ Biroja pārstāvis arī iestājās pret LRTP prasību palielināt propagandas darbu, jo to nav bijis reāli paveikt ar tā brīža līdzekliem. Būtībā LRTP ignorēja reālās problēmas, lai vismaz teorētiski tās darbs veidotos atbilstoši Centrālās tūrisma padomes prasībām, un iepriekšminētās sūdzības LRTP nekomentēja. Vērojamas arī personiskas nesaskan,as starp abu biroju vadītājiem. ${ }^{129}$

\section{Secinājumi}

Lai arī padomju tūrisma būtība bija definēta un mērḳi izvirzīti vēl pirms Otrā pasaules kara, Padomju Savienības principiem atbilstošu centralizētu tūrisma organizāciju neizdevās izveidot līdz pat 20. gadsimta 60. gadiem. Reorganizācijas nepieciešamību varēja pamatot vairākos aspektos: 1919. gada Komunistiskās partijas programma vairs neatbilda pastāvošajai situācijai valstī, radās vajadzība pēc jaunas, ${ }^{130}$ un tūrisms kḷva par vienu no kanāliem, pa kuriem programmas teorija varēja tikt izvirzīta praksē. Cits praktisks iemesls - joprojām ar tūrisma organizēšanu nodarbojās vairākas organizācijas, bet tas padarīja darbu neefektīvu un nesaskan,otu. Organizācijas bija nelielas, tām trūka atbilstoša finansējuma, resursu, vienotības. ${ }^{131}$

Latvijas tūrisma un ekskursiju pārvalde savas neilgās darbības laikā sāka virzību uz tūrisma jomas centralizāciju un ideologizāciju. Pēc jaunas Komunistiskās partijas programmas pieņemšanas sākās jauns ideologizācijas vilnis, kas noteica LTEP darbības mērḳus un tūrisma pasākumu ideologiskos uzsvarus un tieši skāra tūrismu, kas Padomju Savienībā tika izmantots kā padomju identitātes un kopējās vēsturiskās atmiņas veicinātājs. Tūrismam bija jākḷūst par daḷu no cilvēka ikdienas - jebkuram pieejamu aktīvu brīvā laika pavadīšanas veidu, kas norūdītu padomju sabiedrību garīgi un fiziski. ${ }^{132}$

Strauja aktīvo tūristu skaita palielināšanās radīja drošības draudus tūristu un 
tūrisma gidu pieredzes trūkuma dēḷ. Lai atrisinātu šo problēmu, LTEP pievērsās savu darbinieku un tūristu kvalifikācijas uzlabošanai. Par normu kḷuva darbinieku dalība apmācībās, medicīnas personāla piesaiste garākos izbraukumos, kā arī drošības instruktāžas un maršrutu grūtības pakāpju ierobežojumi, tas kopumā vērtējams pozitīivi.

1962. gadā notika pirmā būtiskā padomju tūrisma sistēmas reorganizācija kopš 30. gadiem. LRTP jau lielākā mērā izdevās panākt tūrisma darba centralizāciju, pateicoties lēmumam likvidēt daḷu iepriekšējo tūrisma organizāciju, lai izvairītos no paralēlām funkcijām. ${ }^{133}$ LRTP tika izveidota uz LTEP pamata, bet 60 . gadu laikā tā ievērojami paplašinājās gan darbinieku, gan struktūrvienību skaita ziṇā. 60. gadu laikā gandrīz trīskāršojās tās štata darbinieku skaits (no 6 līdz 17), ${ }^{134}$ taču kopējais tūrisma aktīvistu skaits bija lielāks - tie darbojās LRTP komisijās, sekcijās, tūristu bāzēs un ekskursiju birojos. Padomes darbības sākumā tika dibinātas piecas sekcijas un piecas komisijas, kas 60. gadu laikā paplašinājās, daḷa pārorganizējās. Šīs struktūrvienības veica nozīmīgu darbu tūrisma attīstīšanā - maršrutu izstrādē, tūrisma infrastruktūras projektēšanā, tūrisma popularizēšanā un jaunu tūrisma formu ieviešanā (60. gados jāizceḷ autostopa sistēma un auto-moto tūrisms), sabiedrisko tūrisma organizāciju kontrolēšanā, masu tūrisma pasākumu organizēšanā, lai gan nācās saskarties ar daudzām grūtībām - gan nepietiekamā finansējuma dēḷ, gan darbinieku nolaidības vai entuziasma trūkuma dēḷ.

Ievērojami palielinājās arī tūristu bāzu darbinieku skaits - no $126^{135}$ līdz 218 personām. ${ }^{136}$ Nedaudz palielinājās padomes tūristu bāzu skaits - no trīs ar 350 vietām ${ }^{137}$ lìdz piecām ar 1057 vietām, ${ }^{138}$ kas ir pozitīvs rezultāts, lai gan plašāka celtniecība un paplašināšana tika plānota, bet netika realizēta.
Kā LRTP un to struktūrvienību darbības sasniegums jāizceḷ kvalifikācijas jautājumu risināšana. Organizācija sistemātiski strādāja pie tūrisma kadru mācību programmas sastādī̌̌anas un īstenošanas, kas rezultējās ar tautas tūrisma universitātes izveides plānošanu 1965. gada nogalē, ${ }^{139}$ un jau 1966. gada beigās mērkis bija izpildìts - tika izveidota Republikāniskā tūrisma tautas universitāte, kas palielināja augsti izglītotu ekskursiju vadītāju skaitu. ${ }^{140}$

Centienus uzlabot tūristu kvalifikāciju ir grūti novērtēt kā sasniegumu vai trūkumu, proti, mēǵinājumu uzlabot cilvēku teorētiskās un praktiskās zināšanas tūrisma jomā ar nozīmīšu sistēmas palīdzību. Kaut arī šajā pieejā ir sava log̣ika, praksē tas ne vienmēer palīdzēja, jo dažādus incidentus un individuālo reakciju uz tiem ne vienmēr var kontrolēt.

Vairākās jomās tūrisma vadība joprojām bija dalīta, īpaši bērnu un jaunatnes tūrisma jomā sadarbībā ar Ministru padomes Fiziskās kultūras un sporta komiteju, tomēr tas nemazināja padomes darba efektivitāti, kā tas bija 50. gados, bet gan uzlaboja un attīstīja citu tūrisma attīstības ceḷu - tūrismu kā sporta veidu. Pati LRTP stingrāk virzījās uz masu tūrisma attīstību, iekḷaujoties Centrālās tūrisma padomes nospraustajās robežās, kas bez citu organizāciju iesaistes nozīmētu zināmu tūrisma jomas sašaurināšanos.

Kopumā LRTP stingri ievēroja Centrālās tūrisma padomes principus, bet tas ne vienmēr pozitīvi ietekmēja organizācijas darbu. Tūristu plēnumos bieži vien tika izteikta LRTP darbības kritika, pretenzijas un ieteikumi, kuri netika n,emti vērā, ja neiekḷāvās Centrālās tūrisma padomes darbības filozofijā: tas vērtējams kā nopietns darbības trūkums. Tāpat jāievēro šo aktīvistu entuziasms risināt tūrisma jomas problēmas - ambiciozām personām, kuras saistīja šì joma, bija liela nozīme tūrisma attīstības jautājumu virzīšanā arī 60. gados. 


\section{ATSAUCES UN SKAIDROJUMI}

${ }^{1}$ Raksta pamatā ir autores mağistra darbs "Latvijas tūrisma un ekskursiju pārvaldes (Latvijas republikāniskās tūrisma padomes) darbība 20. gadsimta 60. gados" (Latvijas Universitāte, 2020). Darba zinātniskais vadītājs - Jānis Keruss.

${ }^{2}$ World Travel \& Tourism Council. Travel \& Tourism Regional Performance, 2019. Pieejams: https://wttc.org/Research/Economic-Impact (skatīts 20.09.2020.).

${ }^{3}$ LINDA K. RICHTER. The Politics of Tourism in Asia. Honolulu 1989, p. 4. Pieejams arī: https:// www.jstor.org/stable/j.ctv9zcjr9 (skatīts 29.03.2020.).

${ }^{4}$ Latvijas Republikas Saeima. Tūrisma likums. Pieejams: http://m.likumi.lv/doc. php id = 50026\&amp;version_date $=03.11 .1999$ (skatīts 13.01.2020.).

${ }^{5}$ GRIGORI USYKIN. Ocherki istorii rossiiskogo turizma. Obshchestvo proletarskogo turizma i ekskursii (1927-1936). Sankt-Peterburg 2007. Pieejams arī: https://tourlib.net/books_history/ usyskin08.htm (skatìts 20.12.2019.).

${ }^{6}$ IUlIIA RostovskaIA. Turisticheskaia Pressa v SSSR: harakter stanovleniia i razvitiia. In: Voprosy teorii i praktiki zhurnalistiki, T. 7, No. 1. Irkutsk 2018, s. 26.

7 Ibidem, s. 25.

${ }^{8}$ Nodosim visi balsis par labāku rītdienu. In: Brīvā Zeme, 12.07.1940., 4. lpp.

${ }^{9}$ Kā izmanto atpūtu Padomju Savienības pilsoṇi. In: Brīvā Jaunatne, 08.08.1940., 6. lpp.

${ }^{10}$ ANNE Gorsuch. "There's No Place like Home": Soviet Tourism in Late Stalinism. In: Slavic Review 62, 2003, No. 4, p. 760 (Tourism and Travel in Russia and the Soviet Union). Pieejams arì: https://www.jstor.org/stable/3185654?seq = 1 (skatīts 15.01.2020.).

${ }^{11}$ Latvijas republikāniskā tūrisma padome - vēsturiskā izziņa, 07.05.1971. Latvijas Nacionālais arhīvs, Latvijas Valsts arhīvs, Rīga (turpmāk - LNA LVA), 1755, 1.-2. lp.

${ }^{12}$ GRIGORII USYKIN. Ocherki istorii rossiiskogo turizma. Rozhdenie klubov turistov v strane (19571961). Sankt-Peterburg 2007. Pieejams arì: https://bit.ly/3dNIOca (skatīts 03.04.2020.).

${ }^{13}$ Latvijas republikāniskā tūrisma padome - vēsturiskā izziņa, 16.05.1967. LNA LVA, 1755, 3. lp.

${ }^{14}$ Latvijas Investīciju un attīstības aǵentūra. Tūrisms. Pieejams: https://www.liaa.gov.lv/lv/turismanozarei (skatìts 08.01.2020.).

${ }^{15}$ ERIC G. E. ZuELOW. Teaching: Why Tourism History? Midwest Popular Culture Association Annual Conference in St. Louis, MO, October 14-16, 2005. Pieejams: http://ericzuelow.com/ ModernTourism/WhyTourismHistory.html (skatīts 03.01.2020.).

${ }^{16}$ INETA LIPŠA. VDK ietekme un padomju Latvijas ārzemju tūrisma iestāžu vadošais personāls: Vissavienības akciju sabiedrības "Intūrists" Rīgas nodala un tās operatīvā vadība (1957-1992). In: Latvijas Vēstures Institūta Žurnāls 2017, Nr. 2, 80.-128. lpp.

${ }^{17}$ A. KRAstin̦š. Tūrisms šogad. In: Rīgas Balss, 05.01.1960., 5. lpp.

${ }^{18}$ Latvijas republikāniskā tūrisma padome - vēsturiskā izziņa, 16.05.1967. LNA LVA, 1755, 1.-2. lp.

${ }^{19}$ Par tūrisma un ekskursiju pārvaldi VCSPS [krievu val.], 12.06.1951. Ibidem, 1755-1-2, 1. lp.

${ }^{20}$ Protokols Nr. 54 [krievu. val.], 21.01.1960. Ibidem, 1755-1-3, 5. lp.

${ }^{21}$ AleKSANDRA BRIEDE, JeVgeniJs VASIḶJEVs. Fiziskās audzināšanas un sporta teorētiskie un metodiskie pamati. Rīga 1975, 11. lpp.

${ }^{22}$ GRIGORII UsYKIN. Ocherki istorii rossiiskogo turizma. Turistsko-ekskursionnoe delo v predvoennye gody (1936-1941). Sankt-Peterburg 2007. Pieejams arī: https://tourlib.net/books_history/ usyskin09.htm (skatìts 21.12.2019.).

${ }^{23}$ Par tūrisma un ekskursiju pārvaldi VCSPS [krievu val.], 12.06.1951. LNA LVA, 1755-1-2, 1. lp.

${ }^{24}$ Ibidem, 3. lp.

${ }^{25}$ Ibidem.

${ }^{26}$ RUdolPh SCHLESINGER. Marxist Theory and the New Program of the Soviet Communist Party. In: Science \& Society. New York 1962, p. 129.

${ }^{27}$ Ibidem, p. 133. 
${ }^{28}$ Gatavs pretgaisa aizsardzībai.

${ }^{29}$ Pavēle Nr. 14 [krievu val.], 16.04.1962., Rīga. LNA LVA, 1755-1-11, 18. lp.

${ }^{30}$ Avota tekstā - Pilsoṇu karš un Lielais Tēvijas karš.

${ }^{31}$ Par tūrisma un ekskursiju pārvaldi VCSPS [krievu val.], 12.06.1951. LNA LVA, 1755-1-2, 1. lp.

${ }^{32}$ M. KoRUle. Ziņojums par tūrisma masveidības tālāku attīstību, 1963. Ibidem, 1755-2-1, 4. lp.

${ }^{33}$ Pavēle Nr. 5 [krievu val.], 17.03.1961., Rīga. Ibidem, 1755-1-10, 5. lp.

${ }^{34}$ Pavēle Nr. 27 [krievu val.], 27.06.1961., Rīga. Ibidem, 31. lp.

${ }^{35}$ L. TAMAŠIns. Mazā upīte atrieba jūru. In: Padomju Jaunatne, 13.01.1961., 3. lpp.

${ }^{36}$ Pavēle Nr. 16. Saskaņā ar Latvijas Republikāniskā arodbiedrību padomes prezidija dekrētu 1961. gada 20. aprīlī [krievu val.], 20.05.1961., Rīga. LNA LVA, 1755-1-10, 19. lp.

${ }^{37}$ Pavēle Nr. 2. Sakarā ar slēpotāju tūristu vilciena organizēšanu uz Aizkarpatiem no 1961. gada 5. līdz 15. februārim [krievu val.], 03.02.1961., Rīga. Ibidem, 2. lp.

${ }^{38}$ Pavēle Nr. 15 [krievu val.], 10.05.1961., Rīga. Ibidem, 18. lp.

${ }^{39}$ Pavēle Nr. 54 [krievu val.], 27.11.1961., Rīga. Ibidem, 59. lp.

${ }^{40}$ Pavēle Nr. 56 [krievu val.], 01.12.1961., Rīga. Ibidem, 63. lp.; Pavēle Nr. 9 [krievu val.], 24.02.1961., Rīga. Ibidem, 1755-1-11, 11. lp.

${ }^{41}$ Top modernākā tūristu bāze Latvijā. In: Sociālistiskais Ceḷš, 21.06.1960., 2. lpp.

${ }^{42}$ V. Vìtols. Jauno tūristu vasaras bāzes. In: Zemgales Komunists, 20.05.1960., 3. lpp.

${ }^{43}$ Pavēle Nr. 8. Lēmums par Rīgas ekskursiju bāzes dibināšanas tūrisma un ekskursiju pārvaldes ietvaros [krievu val.], 30.03.1961. LNA LVA, 1755-1-10, 10. lp.

${ }^{44}$ Pavēle Nr. 54 [krievu val.], 27.11.1961., Rīga. Ibidem, 58. lp.

${ }^{45}$ Pavēle Nr. 15 [krievu val.], 10.05.1962., Rīga. Ibidem, 1755-1-11, 19. lp.

${ }^{46}$ Pavēle Nr. 21 [krievu val.], 31.05.1961., Rīga. Ibidem, 1755-1-10, 25. lp.

${ }^{47}$ Pavēle Nr. 5 [krievu val.], 17.03.1961., Rīga. Ibidem, 5. lp.

${ }^{48}$ Pavēle Nr. 54 [krievu val.], 27.11.1961., Rīga. Ibidem, 61. lp.

${ }^{49}$ Ibidem, 60. lp.

${ }^{50}$ Ko tūristiem sola nākamais gads? In: Cīṇa, 25.12.1962., 4. lpp.

${ }^{51}$ Štatu saraksts [krievu val.], 15.01.1966., Maskava. LNA LVA, 1755-4-40, 63. lp.

52 Tūrisma padomes štatu saraksts [krievu val.], 1966. Ibidem, 1755-4-43, 13. lp.

${ }^{53}$ Tūrisma padomes štatu saraksts [krievu val.], 1967. Ibidem, 1755-4-46, 12. lp.

${ }^{54}$ Darba plāns [krievu val.], 13.11.1962., Rīga. Ibidem, 1755-1-13, 31. lp.

${ }^{55}$ Plānošanas un ekspluatācijas komisijas darba plāns [krievu val.], 25.04.1963., Rīga. Ibidem, 1755-1-21, 5. lp.

${ }^{56}$ Plānošanas un ekspluatācijas komisijas darba plāns [krievu val.], 10.07.1963., Rīga. Ibidem, 1755-1-15, 75. lp.

${ }^{57}$ M. P. KLJAP, F. F. SHANDOR. Sovremennye raznovidnosti turizma. Moskva 2011, 69. nodalia. Pieejams arī: http://uchebnikirus.com/turizm/suchasni_riznovidi_turizmu__klyap_mp/klasifikatsiya_ turizmu_zasobami_peresuvannya.htm (skatìts 15.05.2020.).

${ }^{58}$ Darba plāns [krievu val.], 13.11.1962., Rīga. LNA LVA, 1755-1-13, 28. lp.

${ }^{59}$ EgONS ZABLOVSKIS, LİGA ZARIN̦A. No Oliṇkalna līdz Everestam. Rīga 1997, 81. lpp.

${ }^{60}$ Lēmums par vienotu krūšu nozīmīti un emblēmu "LATVIJAS PSR tūrists" [krievu val.], 03.11.1967. LNA LVA, 1755-1-40, 190. lp.

${ }^{61}$ Maršrutu un kvalifikācijas komisijas darba plāns [krievu val.], 10.07.1963., Rīga. Ibidem, 1755-1-15, 77. lp.

${ }^{62}$ Protokols Nr. 2 [krievu val.], 28.10.1963., Rīga. Ibidem, 1755-1-16, 37. lp.

${ }^{63}$ Protokols Nr. 2 [krievu val.]., 26.06.1967., Rīga. Ibidem, 1755-1-40, 19. lp.

${ }^{64}$ Atestācijas un metodiskā darba komisijas darba plāns [krievu val.], 01.04.1963., Rīga. Ibidem, 1755-1-15, 16. lp. 
${ }^{65}$ Protokols Nr. 14 [krievu val.], 13.04.1964., Rīga. LNA LVA, 1755-1-20, 26. lp.

${ }^{66}$ Atestācijas un metodiskā darba komisijas darba plāns [krievu val.], 01.04.1963., Rīga. Ibidem, 1755-1-15, 16. lp.

${ }^{67}$ Organizatoriskās-masu komisijas darba plāns [krievu val.], 01.04.1963., Rīga. Ibidem, 18. lp.

${ }^{68}$ Darba plāns [krievu val.], 13.11.1962., Rīga. Ibidem, 1755-1-13, 30. lp.

${ }^{69}$ Protokols Nr. 3 [krievu val.], 09.01.1963., Rīga. Ibidem, 1755-1-14, 4. 1p.

${ }^{70}$ Stenogramma [krievu val.], 25.04.1968., Rīga. Ibidem, 1755-1-42, 5. lp.

${ }^{71}$ Propagandas un aǵitācijas komisijas darba plāns [krievu val.], 01.04.1963., Rīga. Ibidem, 1755-1-15, 15. lp.

72 Propagandas un ag̣itācijas komisijas darba plāns [krievu val.], 25.04.1964., Rīga. Ibidem, 1755-1-21, 9. lp.

${ }^{73}$ Propagandas un ag̣itācijas komisijas darba plāns [krievu val.], 27.07.1964., Rīga. Ibidem, 1755-1-22, 22. lp.

${ }^{74}$ Telšu pilsētinu tūrisma un veselības nostiprināšanas sekcijas darba plāns [krievu val.], 12.11.1962. Ibidem, 1755-1-13, 18. lp.

75 Telšu pilsētiņu tūrisma un veselības nostiprināšanas sekcijas darba plāns [krievu val.], 13.01.1964., Rìga. Ibidem, 1755-1-20, 18. lp.

${ }^{76}$ Lēmums - protokols Nr. 12 [krievu val.], 25.11.1963., Rīga. Ibidem, 1755-1-16, 69. lp.

77 J. LIEPIN̦Š. Jauniešu nometne kolhozā. In: Cīṇa, 01.06.1957., 2. lpp.

${ }^{78}$ Protokols Nr. 2 [krievu val.], 12.11.1963., Rīga. LNA LVA, 1755-1-13, 16. lp.

${ }^{79}$ Darba plāns [krievu val.], 13.11.1962., Rīga. Ibidem, 32. lp.

${ }^{80}$ Protokols Nr. 1 [krievu val.], 27.01.1969., Rīga. Ibidem, 1755-1-46, 1. lp.

${ }^{81}$ Instruktīva vēstule [krievu val.], 1965. Ibidem, 1755-1-29, 42. 1p.

${ }^{82}$ Nolikums [krievu val.], 21.12.1966., Rìga. Ibidem, 1755-1-36, 49. lp.

${ }^{83}$ Darba plāns [krievu val.], 13.11.1962., Rīga. Ibidem, 1755-1-13, 26.-27. lp.

${ }^{84}$ Masu tūrisma veidu sekcijas darba plāns [krievu val.], 01.04.1962., Rīga. Ibidem, 1755-1-15, 25. lp.

${ }^{85}$ Rīkojums Nr. 41 [krievu val.], 15.05.1964., Rīga. Ibidem, 1755-1-19, 43. lp.

${ }^{86}$ Ūdens tūrisma sekcijas darba plāns [krievu val.], 13.01.1964., Rīga. Ibidem, 1755-1-20, 23. lp.

${ }^{87}$ Mācību plāns - programma [krievu val.], 1963. Ibidem, 1755-1-15, 35. lp.

${ }^{88}$ Protokols Nr. 2 [krievu val.], 28.10.1963., Rīga. Ibidem, 1755-1-16, 33. lp.

${ }^{89}$ Auto-moto tūrisma sekcijas darba plāns [krievu val.], 01.04.1963. Ibidem, 1755-1-15, 20. lp.

${ }^{90}$ Protokols Nr. 1 [krievu val.], 27.01.1969., Rīga. Ibidem, 1755-1-46, 1. lp.

${ }^{91}$ Ibidem, 53. lp.

${ }^{92}$ Ekskursiju darba sekcijas darba plāns [krievu val.], 13.01.1964., Rīga. Ibidem, 1755-1-20, 24. lp.

${ }_{93}$ Brigādes, kas sasniegušas augstu darba ražīgumu (Sovetskaia istoricheskaia enciklopediia).

${ }^{94}$ Protokols Nr. 20 [krievu val.], 23.11.1965., Rīga. LNA LVA, 1755-1-27, 1. lp.

${ }_{95}$ Ibidem, 2. lp.

${ }^{96}$ Ibidem, 4. lp.

${ }^{97}$ LRTP prezidija darba plāns [krievu val.], 25.04.1964., Rīga. Ibidem, 1755-1-21, 18. lp.

${ }^{98}$ V. PAEgle. Tūristi gaida atbildi. In: Padomju Jaunatne, 09.01.1963., 3. lpp.

${ }^{99}$ Protokols Nr. 20 [krievu val.], 23.11.1965., Rīga. LNA LVA, 1755-1-27, 4. lp.

${ }^{100}$ Pamatrādītāji [krievu val.], 10.12.1960. Ibidem, 1755-4-29, 8. lp.

${ }^{101}$ Pamatrādītāji [krievu val.], 27.11.1968. Ibidem, 1755-4-50, 21. lp.

${ }^{102}$ Pamatrādītāji [krievu val.], 10.12.1960. Ibidem, 1755-4-29, 8. lp.

${ }^{103}$ Pamatrādītāji [krievu val.], 27.11.1968. Ibidem, 1755-4-50, 21. lp.

${ }^{104}$ Protokols Nr. 6 [krievu val.], 29.11.1965., Rīga. Ibidem, 1755-1-31, 59. lp. 
${ }^{105}$ Protokols Nr. 10 [krievu val.], 29.09.1969., Rīga. LNA LVA, 1755-1-48, 87. lp.

${ }^{106}$ Latvija - tūrisma novads. In: Komunisma Rìts, 29.07.1969., 4. lpp.

${ }^{107}$ Pielikums Nr. 26 [krievu val.], 22.01.1960., Maskava. LNA LVA, 1755-4-26, 19. 1p.

108 Tūrisma padomes štatu saraksts [krievu val.], 25.11.1968. Ibidem, 1755-4-50, 14. lp.

${ }^{109}$ Pavēle Nr. 24 [krievu val.], 06.06.1961., Rìga. Ibidem, 1755-1-10, 28. lp.

${ }_{110}$ Pavēle Nr. 26 [krievu val.], 27.06.1961., Rīga. Ibidem, 30. lp.

${ }^{111}$ Pavēle Nr. 35 [krievu val.], 12.08.1961., Rīga. Ibidem, 39. lp; Pavēle Nr. 41 [krievu val.], 23.09.1961., Rīga. Ibidem, 45. lp.

${ }^{112}$ Rīkojums Nr. 193 [krievu val.], 06.09.1967., Rīga. Ibidem, 1755-1-41, 214. lp.; Rīkojums Nr. 8 [krievu val.], 11.01.1968., Rìga. Ibidem, 1755-1-45, 8. lp.

${ }^{113}$ Protokols Nr. 4 [krievu val.], 31.08.1965., Rìga. Ibidem, 1755-1-31, 7. lp.

114 Protokols Nr. 21 [krievu val.], 11.09.1964., Rīga. Ibidem, 1755-1-22, 36. lp.

${ }^{115}$ Ibidem, 51. lp.

${ }^{116}$ Ibidem, 41. lp.

117 Ibidem, 44. lp.

${ }^{118}$ Pamatrādītāji [krievu val.], 05.01.1962., Maskava. Ibidem, 1755-4-32, 5. lp.

${ }^{119}$ Latvijas tūrisma maršruti. In: Komunisma Rīts, 17.01.1970., 4. lpp.

${ }^{120}$ Protokols Nr. 6 [krievu val.], 29.11.1965., Rìga. LNA LVA, 1755-1-31, 86. lp.

${ }^{121}$ Ibidem, 131. lp.

${ }^{122}$ Ibidem, 93. lp.

${ }^{123}$ Pavēle Nr. 17 [krievu val.], 15.02.1967., Rīga. Ibidem, 1755-1-41, 18. lp.

${ }^{124}$ Protokols Nr. 6 [krievu val.], 29.11.1965., Rïga. Ibidem, 1755-1-31, 76. lp.

${ }^{125}$ Stenogramma [krievu val.], 25.04.1968., Rīga. Ibidem, 1755-1-42, 14. lp.

${ }^{126}$ Ibidem, 19. lp.

${ }^{127}$ Daugavas tūristu kluba vēstule LRTP [krievu val.], 1969, Daugavpils. Ibidem, 1755-1-47, 106. lp.

${ }^{128}$ Stenogramma [krievu val.], 25.04.1968., Rīga. Ibidem, 1755-1-42, 22. lp.

${ }^{129}$ Ibidem, 20. lp.

${ }^{130}$ SCHLESINGer, Marxist Theory and the New Program of the Soviet Communist Party, p. 129.

${ }^{131}$ ILZE VAIVOdE. Alpīnisma attīstība Latvijas PSR 1960.-1991. g. Rīga 2018, 36. lpp.

${ }^{132}$ MARIIA SoKolova. Istoriia turizma: ucheb. posobie. Moskva 2002, s. 352.

${ }^{133}$ ZABLOVSKIS, ZARIN̦A, No Olinkalna līdz Everestam, 80. lpp.

${ }^{134}$ Darba plāns [krievu val.], 1969. LNA LVA, 1755-4-50, 7. lp.

135 Ibidem, 19. lp.

${ }^{136}$ Tūrisma padomes štatu saraksts [krievu val.], 25.11.1968. Ibidem, 14. lp.

137 Pamatrādìtāji [krievu val.], 10.12.1960. Ibidem, 1755-4-29, 8. lp.

${ }^{138}$ Pamatrādītāji [krievu val.], 25.11.1968. Ibidem, 1755-4-50, 21. lp.

${ }^{139}$ Protokols Nr. 6 [krievu val.]., 29.11.1965., Rīga. Ibidem, 1755-1-31, 77. lp.

${ }^{140}$ Republikāniskās tūrisma tautas universitātes mācību programma, 1966, Rīga. Ibidem, 1755-1-36, 145. lp.

\section{SUMMARY}

The definition and aims of Soviet tourism were formulated before WW2, however, until the 1960s the attempts to establish a centralised tourism organisation were unsuccessful. A reorganisation was needed for political and practical reasons. The renewed Program of the Communist Party of the USSR (CP) was established; therefore tourism became a way 
of channelling the theory of the Program into reality. Furthermore, tourism was organised by many small organisations that lacked funding and unity.

Administration of Tourism and Excursions of Latvia (ATEL) started moving towards the centralisation of tourism and other tasks in the 1960s. After the adoption of the new CP's Program, a new wave of ideologization began. It determined the aims and ideological emphasis of ATEL's work, because tourism in the USSR was used for the promotion of the Soviet identity and united collective memory. Tourism had to become a part of people's everyday life - an active way of spending leisure time, accessible to everyone and intended to toughen the Soviet society physically and mentally.

The rapid growth of the number of tourists created a safety problem because of the lack of experience. To solve this problem, ATEL focused on the improvement of the qualifications of its employees and tourists. Training, recruitment of medical staff, safety briefings, and grade limitations became a norm, and it can be evaluated as a positive thing.

The most meaningful reorganisation of Soviet tourism since the 1930s took place in 1962. The Republican Tourism Council of Latvia (RTCL) was more successful in the centralisation of work related to tourism, because a part of the other organisations was closed down to avoid duplication of work. In the 1960s, this organisation expanded significantly. The number of employees of the council almost tripled (from 6 to 17), but the total number of activists was even larger - they worked in RTCL's departments, tourist centres, excursion offices. The departments consisted of 5 sections and 5 commissions that participated in route development, designed the tourism infrastructure, promoted tourism, organised new forms of tourism (for example, automobile tourism), and mass events. However, they faced many difficulties because of the lack of funding and due to negligence or lack of enthusiasm.

The number of tourist centres and their employees increased, while many plans and projects were not carried out.

The RTCL was quite successful in addressing qualification issues that resulted in a new study programme that improved the number of educated tour guides.

The attempts of improvement of tourist's qualifications are hard to evaluate. The organisation tried to improve theoretical and practical knowledge with the implementation of the system of tourism badges. There was some logic in this, however, in reality it did not always help due to the uncontrollable parts of nature and human reaction.

In some fields, the management of tourism was still divided, especially in children and youth tourism. The RTCL was working with the Committee on Physical Culture and Sport of the Council of Ministers, and it did not hinder the efficiency of work like it did in the 1950s. It improved and helped to develop another kind of tourism - tourism as a type of sport. The RTCL was more focused on the organisation of mass tourism, working within the lines of the Central Tourism Council (CTC). Without cooperation with other organisations, tourism would not expand outside the requirements of the CTC.

Overall, RTCL strictly followed the principles of the CTC. That did not always positively influence their work. In the tourist meetings, many tourists expressed criticism and suggestions to the RTCL, but they were not even acknowledged if they did not represent any of CTC's claims. 


\title{
Latvijas un Krievijas 1998. gada attiecību krīze: cēloṇi un norise
}

\author{
Crisis in Latvian-Russian Relations in 1998: \\ Causes and Progress
}

Eginhards Volāns, Mg. hist.

Latvijas Universitātes Vēstures un filozofijas fakultāte

Aspazijas bulvāris 5, Rīga, LV-1050

E-pasts: eginhards.volans@gmail.com

Raksts ir veltìts 1998. gada Latvijas un Krievijas attiecību krīzei un tās priekšvēstnešiem 1997. gadā. Pētỉjumā secīgi izklāstīti un izpētīti attiecību krīzes galvenie cēloṇi un norise, kā arī sniegts ieskats Latvijas, Krievijas un Rietumvalstu perspektīvā par attiecīgajiem notikumiem. Raksta galvenā avotu bāze ir periodika latviešu un krievu valodā, kā arī zinātniskā literatūra par šo tēmu. Darba pamattekstu veido trīs nodalas, no tām pirmā ir veltìta Latvijas un Krievijas attiecību eskalācijai no 1997. gada marta līdz 1998. gada februārim, otrā - krīzes norisei un izpausmēm no 1998. gada marta līdz aprīlim, trešā - krīzes deeskalācijai 1998. gada vasarā. Raksta tapšanas laikā secināts, ka Latvijas un Krievijas attiecību krīze, visticamāk, bija mākslīgi radīta no Maskavas puses, lai aizkavētu Latvijas eiroatlantisko integrāciju un novērstu Krievijas sabiedrības uzmanību no valstī briestošās iekšpolitiskās un ekonomiskās krīzes.

Atslēgvārdi: Latvijas un Krievijas attiecības, NATO paplašināšanās, Krievijas propaganda, Krievijas ietekmes aktivitātes, Krievijas tautieši.

The article is dedicated to the crisis in Latvian-Russian relations during the spring of 1998, as well as the related developments and preconditions, which already emerged during the 1997 . The author of the article has formulated and discussed the main reasons of the crisis, as well as researched the unfolding of the crisis, yielding insights from the perspective of Latvia, the West and Russian Federation. Latvian and Russian language press, as well as the related scientific literature have been considered as the main sources by the author. The article consists of three main chapters. The first one characterises the gradual escalation of the crisis in Latvian-Russian relations during the period from March 1997 to February 1998, the second chapter explores the development and manifestation of the crisis in 1998 from March to April, whilst the third chapter views the de-escalation of the crisis during the summer of 1998. The research brought a conclusion that the crisis in Latvian-Russian relations was most likely intentionally 
created by the Kremlin in order to slow down the Euro-Atlantic integration process of Latvia, as well as to divert the Russian society's attention from the emerging domestic and economic crisis.

Keywords: Latvian-Russian relations, NATO enlargement, Russian propaganda, Russian influence activities, Russian compatriots.

\section{levads}

Pēc Krievijas agresijas Ukrainā starp Maskavu un Rīgu ir iestājies, iespējams, ilgākais līdz šim pieredzētais atsaluma periods, kā rezultātā abu valstu attiecības ir sasniegušas vienu no vēsturiski zemākajiem punktiem. Turpinoties Maskavas nedraudzīgajai ārpolitikai, tādas tās, visticamāk, saglabāsies arī paredzamā nākotnē. Pēdējo gadu tendences liecina, ka ar Krievijas agresīvo ārpolitiku aizvien biežāk nākas saskarties arī Rietumvalstīm, no kurām daḷa pirms tam nereti iestājās par attiecību normalizāciju ar Maskavu. Pašlaik mūsdienu Krievijas ārpolitiku attiecībā pret Rietumiem vislabāk var raksturot kā virkni slēptu un destruktīvu ietekmes aktivitāšu, kuras nereti tiek definētas, izmantojot terminu "hibrīdkarš". Lai gan Rietumu sabiedriskajā domā "hibrīdkaru" mēdz aprakstìt kā salīdzinoši jaunu metodi, ar kuras palīdzību valstis cenšas palielināt savu geopolitisko ietekmi, postpadomju pieredzē tā drīzāk ir vērtējama kā daḷa no ierastās Maskavas ārpolitikas prakses.

Vēl jo vairāk - 1998. gada pavasarī Latvijas valdībai bija iespēja izbaudìt šāda veida ārpolitikas praksi visā tās krāšņumā. 1998. gada Latvijas un Krievijas attiecību krīzes laikā Latvija guva vērtīgu pieredzi, kā pareizi rīkoties, saskaroties ar Krievijas ietekmes aktivitātēm, kā tās vērtēt un kā tām atbildēt. Ar Latvijas pieredzes stāstu būtu vērts iepazīties arī citām Eiropas valstīm, kuras tikai tagad ir sākušas skaḷi runāt par Krievijas radītajiem draudiem.

Šì raksta mērḳis ir sniegt logisku un vispusīgu Latvijas un Krievijas 1998. gada krīzes un pirmskrīzes posma notikumu izklāstu, iezīmējot un analizējot Latvijas, Krievijas un Rietumvalstu darbības un reakciju uz attiecīgajiem notikumiem. Darbā izmantota vēstures genēzes jeb aprakstošā metode, ar kuras palīdzību ir rekonstruētas krīzes galvenās vēsturiskās cēlonssakarības. Pētījumā īpaša uzmanība veltīta tam, lai attēlotu ne tikai Latvijas, bet arī Krievijas un Rietumvalstu perspektīvu krīzes kontekstā, kā arī aplūkotas krīzes izpausmes Latvijas sabiedrībā, kuras varēja radīt potenciālus draudus valsts drošībai. Raksta pamatā ir periodikas avoti latviešu un krievu valodā, kuri aktīvi vēstīja par tālaika notikumiem. Papildus tam kā īpaši uzteicami informācijas avoti jāmin arī tēmai veltītie laikabiedru Žanetas Ozolin,as un Aivara Strangas zinātniskie darbi.

Kaut arī 1998. gada Latvijas un Krievijas attiecību krīze ir vērtējama kā nozīmīgs notikums mūsdienu Latvijas vēsturē, kopumā vēsturnieku un politologu darbos tā apskatīta maz. Jaunākie krīzei veltītie pētījumi datējami ar jaunās tūkstošgades sākumu, un to vērtējumos trūkst mūsdienu perspektīvas.

\section{Latvijas un Krievijas attiecību krīzes priekšvēstneši}

90. gadu vidū pēc Krievijas armijas izvešanas Rīgas un Maskavas attiecībās bija iestājies relatīva miera periods, kurā dominēja primāri ekonomiskās intereses. ${ }^{1}$ Latvijas eiroatlantiskās integrācijas procesi bija nosacīti apstājušies un neradīja tiešus draudus Maskavai, kas savukārt pēc Jevgenija Primakova (Evgenij Primakov) stāšanās ārlietu ministra amatā bija pievērsusies daudzvektoru ārpolitikas īstenošanai 
un škietami aizmirsusi par savām interesēm Baltijā. Tā, protams, bija tikai monētas redzamā puse, un Latvija ne tuvu nebija nozudusi no Maskavas lēmumu pieṇēmēju redzesloka.

1997. gada sākumā Maskavas ārpolitikas aktivitātes liecināja, ka Kremlis ir sācis izstrādāt jaunu stratēg̣iju attiecībā pret Baltijas valstīm - Maskavas primārais mērķis bija kavēt to integrāciju NATO. Krievijas lēmumu pieṇēmēji, visticamāk, juta, ka attiecības starp ASV un Baltijas valstīm ir sākušas "uzsilt" un pēdējo uzn,emšana Ziemel̦atlantijas līguma organizācijā varētu pienākt ātrāk, nekā paredzēts pirms tam. Rezultātā Maskava nolēma rīkoties, lai bez cīnas neatdotu tai stratēgiski svarīgās pozīcijas Baltijā.

Kremḷa plāni palielināt spiedienu pret Baltijas valstīm pirmo reizi izgaismojās ASV un Krievijas samita laikā Helsinkos. Maskava bija nolēmusi to izmantot kā platformu, lai aktualizētu tai svarīgus ārpolitiskus jautājumus, tostarp par Baltijas valstu geopolitisko orientāciju. Samita laikā Krievijas prezidents Boriss Jeḷcins (Boris El'cin) pirmo reizi publiski ierunājās par sava veida drošības garantiju piedāvāšanu Latvijai, Lietuvai un Igaunijai. Drošîbas garantijas tika prezentētas kā reǵiona "pozitīva kontrole"3 no Maskavas puses. Tās ietvaros Krievija solīja samazināt savu militāro klātbūtni reǵionā apmaiņā pret NATO paplašināšanas apturēšanu. Maskavas ieskatos Baltijas valstīm bija jākḷūst par vāji militarizētu buferzonu starp NATO un Krieviju.

Baltijas valstis vēl pirms samita sākuma bija manāmi satraukušās par iespējamo ietekmes pārdali reǵionā. Uz ASV un Krievijas sarunām īpaši asi reaǵēja Latvija, kuras Ministru prezidents Valdis Birkavs bažīgi secināja, ka Latviju joprojām vajā "Jaltas rēgs". ${ }^{4}$ Baltijas valstu satraukums bija pamatots - vēlāk noskaidrojās, ka papildus publiski piedāvātajām drošības garantijām B. Jeḷcins, sekojot "labākajai" padomju laiku praksei, aizkulišu sarunās bija piedāvājis ASV prezidentam Bilam Klintonam (Bill Clinton) noslēgt nerakstītu vienošanos, kurā B. Klintons apsolìtu neuzn,emt Baltijas valstis NATO. ${ }^{5}$ Kaut arī Maskava izrādīja iniciatīvu, Vašingtonas reakcija bija vēsa. Nekas neliecināja, ka ASV būtu gatavas atkāpties no plāniem nostiprināt savu ietekmi Baltijas jūras regíonā. Rezultātā pēc Helsinku samita Kremlis bija nonācis pie atziņas, ka ir iedzīts strupceḷā un vairs nav spējīgs runāt vienā līmenī ar ASV par ietekmi Baltijas valstīs. ${ }^{6}$

Pēc Helsinku samita gan bija vērojams de facto atsalums NATO un Krievijas attiecībās, tomēr 27. maijā abas puses parakstīja Divpusējo attiecību, sadarbības un drošǐbas dibināšanas aktu. Tas izsauca vērā ņemamu Krievijas konservatīvi orientētās elites kritiku. Piemēram, ietekmīgais politologs, Krievijas Ārpolitikas un drošības padomes vadītājs Sergejs Karaganovs (Sergej Karaganov) uzstāja, ka Maskavai jānovilcina akta parakstǐšana vismaz līdz NATO Madrides samitam jūlijā, kad Kremlis varētu gūt apstiprinājumu, ka alianse neplāno paplašināties uz bijušo postpadomju valstu rēķina. ${ }^{7}$ Savukārt PSRS ārlietu ministra Vjačeslava Molotova (Vjacheslav Molotov) mazdēls, Krievijas Valsts domes (VD) deputāts Vjačeslavs N̦ikonovs (Vjacheslav Nikonov), minēto līgumu uzskatīja par tik neizdevīgu Krievijai, ka pat salīdzināja ar Vācijai uzspiesto 1919. gada Versaḷas līgumu. ${ }^{8}$ Maskavai neizdevīgā dokumenta parakstī̌sana lika vēl vairāk apzināties, ka tai sāk trūkt reālu ietekmes sviru, lai aizkavētu Baltijas valstu iestāšanos NATO.

To apstiprināja arī jūlijā aizvadītais Madrides samits, kurā NATO pauda atbalstu Polijas, Čehijas un Ungārijas uzaicināšanai piedalīties aliansē, kā arī neoficiāli lika noprast, ka šì nebūs pēdējā alianses paplašināšanās kārta. ${ }^{9}$ Samita deklarācija bija skaidrs mājiens Kremlim, ka Baltijas 
valstis agrāk vai vēlāk tiks uzņemtas NATO. Samitā paustā retorika bija katalizators Maskavas pieaugošajam aizvainojumam pret NATO ambīijā̄m Austrumeiropā. Krievija bija nonākusi pie slēdziena, ka Baltijas valstu jautājumu vairs nevar atrisināt multilaterālā ceḷā un Maskavas attiecības ar baltiešiem turpmāk ir jāveido aci pret aci.

\section{Krievijas piedāvātās drošības garantijas}

5.-6. septembrī Viḷnāa tika aizvadīts Austrumeiropas valstu samits "Nāciju līdzāspastāvēšana un labas kaimin, attiecības", tajā valdošā retorika no Krievijas amatpersonu puses liecināja, ka Maskava, neņemot vērā sakāvi Madridē, ir apṇēmusies atkārtoti mēǵināt aizkavēt Baltijas valstu eiroatlantiskās integrācijas procesu. Piemēram, īsi pirms ierašanās Viḷnā Krievijas premjerministrs Viktors Černomirdins (Viktor Chernomyrdin) bija publiski paziņojis, ka Krievija iebilst pret Baltijas uznememšanu $N A T O,{ }^{10}$ savukārt samita laikā viņš atkārtoja iepriekš Helsinkos izskanējušo ideju par drošības garantijām. ${ }^{11}$ Vēl jo vairāk, Krievijas nodomus pretdarboties alianses ekspansijai reǵionā apstiprināja arī aizsardzības ministra Igora Sergejeva (Igor' Sergeev) pazinojumi, ka Krievija ir gatava palielināt savu militāro klātbūtni Kalininingradas apgabalā saistībā ar NATO aktivitātēm reǵionā. ${ }^{12}$

Baltijas valstu, sevišķi Latvijas, reakcija uz pieaugošajām Krievijas ārpolitikas aktivitātēm ir vērtējama kā novēlota. Augustā Latvijā pie varas bija nākusi jauna valdība, ko vadīja Guntars Krasts, kurš pārstāvēja nacionālistu partiju "TB/ LNNK". Lai gan Maskavas neapmierinātība ar Latvijas jauno valdību bija viegli paredzama, G. Krasta vadītais Ministru kabinets izlikās to nemanām. Rezultātā jaunās valdības deklarācijā Krievija bija pieminēta vien divas reizes, turklāt uzsverot nepieciešamību "turpināt labu kaimiņattiecību veidošanu”. ${ }^{13}$ G. Krasta valdības pasīvā nostāja pret Krieviju saglabājās arī pēc Maskavas amatpersonu pazinojumiem Viḷnas samitā. Piemēram, intervijā Latvijas krievvalodīgajam laikrakstam SM G. Krasts maldinoši apgalvoja: B. Jeḷcina īstenotā atvērto durvju politika ir pierādījums tam, ka Krievijas ārpolitikā dominējošu lomu ir ieṇēmusi reālistiska, nevis ideologiska attieksme pret Baltijas valstīm. ${ }^{14}$ Latvijas valdības amatpersonu publiskie izteikumi liecināja, ka tai bija vāja izpratne par notikumiem Maskavā un tās plāniem attiecībā pret Baltiju. To ievēroja arī Kremlis, kas Latvijas izvairīgo un pasīvo retoriku, visticamāk, interpretēja kā vājumu un aicinājumu palielināt spiedienu.

Tajā pašā laikā Krievijas ārpolitikā aizvien vairāk nostiprinājās pret Baltiju un NATO vērsts redzējums, kas bija saistīts ar vairākām būtiskām izmaiṇām valsts varas gaiteņos. Piemēram, septembrī no amata Prezidenta administrācijā bija spiesti šķirties ilglaicīgie B. Jeḷcina līdzgaitnieki Levs Suhanovs (Lev Suhanov) un Georgijs Satarovs (Georgij Satarov), neilgi pirms tam amatus bija pametuši arī Aleksandrs L,ivšics (Aleksandr Livshic), Jurijs Baturins (Jurij Baturin), Viktors Iljušins (Viktor Iljushin) un Mihails Krasnovs (Mihail Krasnov). Minētās personas atbalstijja Krievijas tuvināšanos ar Rietumiem un noderēja kā pretsvars politiskajā elitē pieaugošajai konservatīvo spēku ietekmei. ${ }^{15}$ Kremḷa liberālā spārna vājums, kā arī B. Jeḷcina pieaugošās veselìbas problēmas bija par iemeslu tam, ka 1997. gada nogalē Krievijas ārpolitikas groži bija praktiski nonākuši pretrietumnieciski noskan,oto politiḳu un ierēdniecības rokās.

Krievijas konservatīvo politiķu perspektīva uzskatāmi atspoguḷojās zinātniskajā konferencē "Krievija un Centrāleiropa 
jaunos geopolitiskos apstākḷıs”, kas oktobra sākumā notika Maskavā. Uzstājoties konferencē, varai pietuvinātais akadēmiķis Oḷegs Bogomolovs (Oleg Bogomolov) norādijja, ka pasaulē ir "izjaukts starptautiskais līdzsvars", "visur notiek ASV iejaukšanās" un "Krievijas ārpolitika turpmāk ir jāveido, izrietot no šīm geopolitiskajām reālijām". Līdzīgās domās bija arī parlamenta priekšsēdētāja vietnieks Sergejs Baburins (Sergej Baburin), kurš asi kritizēja NATO "ekspansiju", arī norādot, ka tās patiesais mērḳis ir "pakḷaut" Austrumeiropas valstis un vājināt Krievijas ietekmi Eiropā. ${ }^{16}$

Oktobra beigās Krievija beidzot uzrunāja visas trīs Baltijas valstis ar oficiālu drošîbas garantiju piedāvājumu. ${ }^{17}$ Tas, visticamāk, vērtējams kā tieša Maskavas atbilde uz 14. oktobrī aizvadīto ASV un Baltijas valstu tikšanos, kuras laikā Vašingtona apsolīja, ka drīzumā varētu parakstīt ilgi gaidīto partnerības hartu. ${ }^{18}$ Lai gan šì bija jau trešā reize gada laikā, kad Krievija publiski izvirzija ideju par drošības garantijām Baltijas valstīm, tā pirmo reizi izskanēja tik nopietnā tonī un zināmā mērā nāca kā pārsteigums gan Baltijas valstīm, gan to Rietumu partneriem.

Vēsturnieka A. Strangas vērtējumā Krievijas drošības garantijām bija trīs mērkii:

- pirmkārt, pārbaudīt Rietumvalstu reakciju un pārliecināties, cik tālu tās ir gatavas iet, lai atbalstītu Baltijas valstis;

- otrkārt, mazināt Baltijas valstu vienotỉbu; ${ }^{19}$

- treškārt, radīt iekšpolitiskās diskusijas un nemieru Baltijas valstīs, aktualizējot ideju par sadarbību ar Maskavu. ${ }^{20}$

Latvijas reakcija uz drošības garantijām bija saasināta un zināmā mērā haotiska. Valsts prezidents Guntis Ulmanis jau 25. oktobrī uzreiz pēc garantiju piedāvāšanas Lietuvai, nesagaidot oficiālu Latvijas Ārlietu ministrijas (ĀM) iesniegumu, tās nekavējoties noraidīja. ${ }^{21}$ Vēl vairāk - prezidents Krievijas drošības garantijas bija nievājoši nodēvējis par vienkāršu "papīra gabalu". ${ }^{22}$

Pret garantijām negatīvi noskaņoti bija arī citi Latvijas sabiedriskās domas līderi. Piemēram, Latvijas Ārpolitikas institūta vadītājs Atis Lejiņš izcēla, ka to pieņemšana nozīmētu Latvijas atgriešanos Krievijas ietekmes sfērā. Savukārt Saeimas deputāts Aleksandrs Kiršteins bažijās, ka garantijās nav atrunāts rīcības plāns gadījumā, ja Krievija uzbruktu Latvijai. Ironiskā kārtā pret garantijām kritiski noskan,ots bija pat Kremlim tradicionāli draudzīgais bijušais Latvijas ārlietu ministrs Jānis Jurkāns, kurš uzsvēra, ka ar to pieņemšanu divpusējā formātā "Latvijai būtu par maz". ${ }^{23}$

A. Strangas vērtējumā Rīgas asā reakcija pret drošības garantijām bija saistīta ar to, ka tās nerespektēja Latvijas viedokli, kā arī bija noformulētas pakta formā, kam Baltijas valstīs bija īpaši negatīva vēsturiskā konotācija. ${ }^{24}$ Vēsturiskās perspektīvas nozīmi izcēlusi arī politoloǵe Ž. Ozoliṇa, kuras vērtējumā baltiešu negatīvo attieksmi pret drošības garantijām ietekmēja arī Vācijas sākotnējais lēmums tās atbalstīt. ${ }^{25}$ Rezultātā Latvijas sabiedriskā doma nevil,us vilka paralēles starp Krievijas drošības garantijām 1997. gada rudenī un PSRS uzspiesto bāzu līgumu 1939. gada rudenī.

Lai gan starp politikiiem un sabiedrību valdīja vienprātība drošības garantiju vērtējumā, Baltijas valstis kavējās ar to oficiālu noraidīšanu. Lietuva to izdarīja 1. novembrī, Igaunija 2. novembrī, Latvija tikai 4. novembrī. ${ }^{26}$ Galu galā 8. novembrī Baltijas valstu ārlietu ministri nāca klajā ar kopīgu paziņojumu, ka noraida jebkāda veida divpusējās drošības garantijas no Krievijas puses. ${ }^{27}$

Lai gan Baltijas valstu lēmums vienoties kopīgā drošǐbas garantiju noraidīšanā ir vērtējams kā pozitīvs diplomātiskās prakses piemērs, tas nāca krietni par vēlu un liecināja, ka starp tām trūkst efektīvu 
sadarbības mehānismu. Īpaši vāja šajā laikā izskatījās Latvija, kuras darbībās atklājās arī vērā nnemamas starpresoru komunikācijas problēmas - atseviškas valsts augstākās amatpersonas bija at!̣āvušās komentēt Krievijas piedāvājumu bez saskaṇošanas ar ĀM. Tas radijja priekšstatu par Latvijas nespēju sekmīgi pārvarēt krīzes situācijas un liecināja par valdības vājajām diplomātijas spējām.

Tā kā Krievijas puse, visticamāk, necerēja, ka Baltijas valstis vai vismaz kāda no tām patiešām varētu garantijas pieņemt, to galvenais adresāts bija Rietumvalstis. Līdz ar to Maskavas perspektīvā drošības garantiju piedāvājums bija vērtējams kā vairāk vai mazāk izdevies:

- baltiešu tūḷāšanās ar garantiju noraidīšanu un savstarpējās komunikācijas trūkums radīja priekšstatu par to vienotības iluzoriskumu;

- Latvijas valdības haotiskā reakcija, atbildot uz garantijām, liecināja, ka tā nav gatava darbam sarežgìitās situācijās;

- Latvijas diplomātiskā takta trūkums, atbildot uz garantijām, pavēra durvis tās diskreditācijai Rietumu partneru vidū, prezentējot Krieviju kā labu attiecību iniciatoru;

- Rietumvalstu ieturētā reakcija lika domāt par to solidaritātes trūkumu attiecībā uz Baltijas valstīm.

Tikmēr pašas Krievijas reakcija uz drošības garantiju noraidī̌̌anu bija divējāda. No vienas puses, pragmatiskāk noskan,otie elites pārstāvji saprata, ka garantijām nebija reāla svara reǵiona drošības politikas darba kārtībā. Piemēram, Krievijas VD debatēs drošības garantijas tika pieminētas vien garāmejot, par galveno problēmu Latvijas un Krievijas attiecībās atzīstot sasāpējušo tautiešu jautājumu. ${ }^{28}$ No otras puses, radikālāk noskaņotā elites daḷa garantiju noraidīšanu uztvēra ar tai ierasto histēriju, piemēram, Liberāldemokrātu partijas līderis Vladimirs Žirinovskis (Vladimir Zhirinovskij) asi kritizēja Baltiju, minot, ka "Baltijas valstu valdības uzvedas bezkaunīgi”. Odiozais politikisis spekulēja, ka drošības garantiju noraidīšanai būs tālejošas sekas: 2000. gadā Krievijas teritorija būs sarukusi līdz 15. gadsimta izmēriem; Krievijas Tālie Austrumi piederēs kīniešiem un japāṇiem, bet Kaukāzā būs sācies jauns karš. Pēc V. Žirinovska domām, tas bija ASV prezidenta B. Klintona plāns Krievijas pilnīgai sagrāvei. ${ }^{29}$

\section{Latvijas un Krievijas attiecību eskalācija pēc drošǐbas garantiju noraidīšanas}

Decembra sākumā Krievijas prezidents B. Jeḷcins viesojās Zviedrijā, kur, uzrunājot parlamentu, negaidīti paziņoja, ka Krievija līdz 1999. gada 1. janvārim ir gatava par $40 \%$ samazināt savu bruṇoto spēku klātbūtni valsts ziemeḷietumos, un mudināja līdzīgi rīkoties arī citas reǵiona valstis. ${ }^{30}$ Kārtējo prezidenta B. Jeḷcina ekscesu Baltijas reǵiona virzienā nekavējoties izlaboja ārlietu ministrs J. Primakovs, kurš bija spiests precizēt, ka, neņemot vērā Maskavas vēlmi sadarboties ar tās Rietumu partneriem, tā joprojām stingri iebilst pret NATO ienākšanu reǵionā. ${ }^{31}$

Krievijas prezidenta pazinojumi Stokholmā kārtējo reizi apstiprināja aizdomas par Krievijā briestošo iekšējo nestabilitāti. Šajā laikā Krievijā bija aktualizējies jautājums par ietekmīgā liberālā reformatora Anatolija Čubaisa (Anatolij Chubajs) iespējamo atstādināšanu no pirmā vicepremjera amata. ${ }^{32}$ Tāpat neskaidrības saistībā ar Krievijas nākotni radīja bažas par B. Jeḷcina veselības stāvokli, kas strauji pasliktinājās. ${ }^{33}$ Vēl jo vairāk, uz iekšpolitisko intrigu fona valstī turpināja strauji pasliktināties arī ekonomiskā situācija. ${ }^{34}$ Nemot vērā visus iepriekš minētos faktorus, bija 
skaidrs, ka šādos apstākḷlos Maskava drīz vairs nebūs spējīga īstenot konsekventu, uz ilgtermiṇu vērstu ārpolitiku.

1997. gada izskaṇā Krievijas iekšējās problēmas zināmā mērā nāca par labu Baltijas valstīm, kas pēc drošības garantiju noraidīšanas varēja turpināt sekmīgu eiroatlantiskās integrācijas procesu bez bažām par tiešu Maskavas iejaukšanos. Rezultātā 13. decembrī Latvija beidzot saṇēma uzaicinājumu no Briseles uzsākt sarunas par iestāšanos Eiropas Savienībā (ES). ${ }^{35}$ Savukārt nākamā gada 16. janvārī Baltijas valstu prezidenti Vašingtonā parakstīja ilgi gaidīto Partnerības hartu ar ASV. ${ }^{36}$

Krievijas perspektīvā hartai tikai atvēlēta noteicošā loma reǵiona nākotnes veidošanā. Rezultātā jaunais gads tika iesākts ar agresīvu retoriku no Krievijas diplomātu puses, kas jau bija kḷuvusi par tradīciju. Piemēram, Krievijas ārlietu ministrs J. Primakovs vēl pirms hartas parakstīšanas bija skaidri pateicis, ka Maskava to atzīs tikai tādā gadījumā, ja tā pilnvērtīgi spēs aizstāt baltiešu dalību NATO. ${ }^{37}$ Lìgumam asus vārdus veltīja arī J. Primakova vietnieks Aleksandrs Avdejevs (Aleksandr Avdeev), kurš paziņoja, ka tas izjauks drošîbas līdzsvaru ne tikai Baltijā, bet visā Eiropā. ${ }^{38}$ Savukārt Krievijas ĀM pēc hartas parakstǐšanas demonstratīvi pazinoja, ka PSRS nekad nav okupējusi Baltijas valstis. ${ }^{39}$ Maskavas asā publiskā retorika bija mājiens, ka, neņemot vērā iekšpolitisko vājumu, tā tomēr negrasās samierināties ar Baltijas valstu nonākšanu ASV ietekmes sfērā.

Rezultātā 1998. gada sākumā vairāki indikatori liecināja, ka pēc hartas parakstīšanas Maskava varētu būt sākusi palielināt pret Latviju izdarīto spiedienu. Par to liecināja tas, ka, piemēram, Simona Vīzentāla centrs bija vērsies pie ASV prezidenta B. Klintona, lai apvainotu Latviju nacisma reabilitācijā. ${ }^{40}$ Tajā pašā laikā vairākas Latvijas krievu kopienas organizācijas bija nosūtījušas Krievijas premjerministram V. Černomirdinam vēstuli, kurā apvainoja Latvijas valdību krievu minoritātes tiesību pārkāpšanā. ${ }^{41}$ Bez tam Latvijas mediji ziņoja, ka valstī ieradusies Maskavas sociologu grupa, kas Krievijas valdības uzdevumā pētīja iedzīvotāju attieksmi pret politiskajiem, ekonomiskajiem un sociālajiem procesiem. ${ }^{42}$ Sociolog̣iskās aptaujas bija veiktas visās lielākajās Latvijas pilsētās, turklāt, kā noskaidrojās vēlāk, pētnieki bija melojuši un sākotnēji uzdevušies par Francijas sociologisko pētījumu centra pārstāvjiem. ${ }^{43}$ Krievijas intereses palielināšanos pamanīja arī Latvijas parlamentārieši. Piemēram, deputāts Guntis Eniņš vienā no Saeimas sēdēm bažīgi secināja, ka Latvijas krievu kopienas spiediens pret Latvijas valsti ir kluvis "pamatīgs un pietiekami briesmīgs", kā arī mudināja kolēguus būt uzmanīgiem un korektiem, izstrādājot iecerētos labojumus nepilsoṇu likumā. ${ }^{44}$ Lai gan atbildīgās institūcijas šos un citus indikatorus komentēja izvairīgi, bija skaidrs, ka Latvija atkal ir nonākusi Krievijas uzmanības centrā.

Vēl vairāk saspīlējumu abu pušu attiecībās palielināja Latvijas lēmums publiski atbalstīt ASV pozīcijas Irākas krīzē. Tuvo Austrumu jautājumā Maskava bija gājusi pat tik tālu, ka apvainoja Vašingtonu centienos izraisīt Trešo pasaules karu. ${ }^{45}$ Rezultātā prezidenta G. Ulmaņa februārī paustā apṇēmība atbalstīt ASV armiju un nosūtīt uz Irāku līdz 15 militārpersonām ${ }^{46}$ Kremḷa perspektīvā tika interpretēta kā nedraudzīga un pat atklāti provokatīva.

\section{Latvijas un Krievijas attiecību krīze}

Par 1998. gada Latvijas un Krievijas attiecību krīzes katalizatoru ir pien,emts uzskatīt 3. martā aizvadīto nesankcionēto mītinu pie Rìgas Domes (RD). Mìtiņa 
iegansts bija iepriekšējā dienā laikrakstā Panorama Latvii publicētais žurnālistes Innas Harlanovas raksts par komunālo maksājumu celšanu, kam bija pievienots aicinājums lasītājiem pulcēties protesta akcijā. ${ }^{47}$ Publikācijas iespaidā uz mītinu bija ieradušies aptuveni 1000 krievvalodīgie seniori. Saasinoties protestētāju retorikai, daḷa sanākušo izgāja uz Krišjāṇa Valdemāra ielas braucamās daḷas un uz 45 minūtēm paralizēja satiksmi. ${ }^{48}$ Kaut arī varas iestādes centās izveidot dialogu, policistu lūgumi atbrīvot brauktuvi netika uzklausīti, kā rezultātā mìtiņš tika izgaiṇāts ar spēku. ${ }^{49}$

Protesta akcijas izgain̄āšana sākotnēji izpelnījās vietējo mediju otršķirīgu uzmanību un tika vērtēta kā pamanāms, taču salīdzinoši maznozīmīgs incidents. Piemēram, valsts populārākajā laikrakstā "Diena" tas pieminēts tikai 3. lappusē, savukārt "NRA" un "Lauku Avīzē" tam atvēlēta daḷa no 2. lappuses. Pavisam cita situācija vērojama krievvalodīgajos medijos, kur protesta akcijai tika pievērsta pārspīlēti liela uzmanība un tā tika atspoguḷota izteikti emocionālā tonī. Latvijas lielākajos krieviski rakstošajos laikrakstos $S M$, Chas un Panorama Latvii mītiņš atspoguḷots titullapā, turklāt rakstu saturs bija izteikti naidīgs Latvijas valstij. Arī Krievijas mediji it kā mazsvarīgo protesta akciju atspogul,oja plašās detaḷās. Vēsturnieks A. Stranga min, ka jau nākamajā dienā tai uzmanību pievērsa mediji, kuri pieder Krievijas oligarhiem Borisam Berezovskim (Boris Berezovskij) un Vladimiram Gusinskim (Vladimir Gusinskij). ${ }^{50}$ İpašu lomu marta sākumā ieņēma tieši Krievijas oligarhiem piederošie televīzijas kanāli, kas Latvijai veltīja vairākus naidīgi noskaņotus propagandas sižetus. ${ }^{51}$ Tajos tika rādīti videomateriāli ar piketa dalībnieku izgaiņāšanu un apgalvots, ka šādā veidā Latvijas varas iestādes vēršas pret vietējo krievvalodīgo minoritāti. Izteikti naidīgā un koordinētā propagandas kampaņa liecināja, ka tā varētu būt pasūtīta "no augšas". ${ }^{52}$

Jau 4. martā notikumus Latvijā komentēja arī Krievijas augstākās amatpersonas. Piemēram, ārlietu ministrs J. Primakovs protesta izgaiṇāšanu raksturoja kā "kliedzošu cilvēktiesību pārkāpumu”, Latvijas policijas darbības nosauca par "pretīgām” un norādīja, ka pievērsīs šì jautājuma risināšanai arī Polijas ārlietu ministra Bronislava Geremeka (Bronislaw Geremek) uzmanību - viṇš tobrīd ieṇēma (Eiropas Drošības un sadarbības organizācijas (EDSO) priekšsēdētāja amatu. ${ }^{53}$ Ar paziņojumiem, kas vērsti pret Latviju, klajā nāca arī prezidenta preses sekretārs Sergejs Jastšembskis (Sergej Jastrzhembskij), kurš paziṇoja, ka B. Jeḷcins solidarizējas ar J. Primakovu, kā arī norādīja, ka tuvākajā laikā Krievijas un Latvijas prezidentu tikšanās vairs nebūs iespējama. ${ }^{54} 6$. martā Latvijas kritikai pievienojās arī premjerministrs V. Černomirdins, kurš nosodīja iepriekš izskanējušos Latvijas premjera G. Krasta izteikumus, ka pensionāru mītiņš pie RD varēja būt Krievijas provokācija. ${ }^{55}$

Tajā pašā laikā pret Latviju vērstās aktivitātēs sāka iesaistīties arī vairākas radikālas organizācijas, kurām it kā nebija sakara ar valdību. Piemēram, komunistu kustība "Darba Krievija” bija noorganizējusi mītinu pie Latvijas vēstniecības Maskavā. Organizācijas vadītājs Viktors Anpilovs (Viktor Anpilov) sanākušos bija mudinājis "radīt neizturamus apstākḷus Latvijas vēstniecības darbiniekiem", taču Krievijas varas iestādes protesta akcijas norisē neiejaucās. ${ }^{56}$ Lai gan kaimiņvalsts oficiālie avoti ziṇoja, ka pasākumā kopā piedalījās aptuveni 1500 personas, Latvijas vēstniecības pirmais sekretārs Vilmārs Heniņš savos aprēḳinos bija "nedaudz" pieticīgāks un telefonintervijā laikrakstam "Diena" norādīja, ka mītinu apmeklēja vien 15-20 personas un tas tika aizvadìts "tradicionālas demagogijas garā". ${ }^{57}$ 
Papildus tam Krievijas puse īstenoja virkni darbību, kas praktiski iesaldēja abu valstu sadarbību diplomātiskā līmenī. Piemēram, 6. martā tika atcelta VD priekšsēdētāja Genādija Seḷezņova (Gennadij Seleznjov) vizīte Latvijā. No ieplānotā Latvijas apmeklējuma atteicās arī Krievijas varas partija "Mūsu mājas - Krievija". Vēl vairāk - VD deputāti mudināja Krievijas prezidentu īstenot atbildes pasākumus pret Latviju. Maskavas varas kuluāros sāka klīst baumas par iespējamu ekonomisko sankciju ieviešanu. ${ }^{58}$ Rezultātā marta sākumā īsā laika posmā pret Latviju bija nostājušies praktiski visi lielākie aktori, kuri īstenoja Krievijas ārpolitiku. Tas iezīmēja pagrieziena punktu krīzes eskalācijā - kopš šì brī̌̌a bija skaidrs, ka abu valstu attiecību pasliktināšanās ir nevis nejaušība, bet gan mērk,tiecīga Maskavas politika.

8. martā prezidenta preses sekretārs S. Jastšembskis pirmo reizi publiski pazinoja, ka prezidenta ārpolitikas padomnieki iesaka ieviest pret Latviju tirdzniecības ierobežojumus. ${ }^{59}$ Sajūsmu par ekonomisko sankciju ieviešanu neslēpa Latvijas krievvalodīgā prese. Piemēram, laikraksts $S M$ zin,oja, ka Krievijas sankcijas būs vērstas pret Latvijas biznesa aprindām, kas "barojas" no Krievijas tranzìta un tomēr diskriminē krievu minoritāti. ${ }^{60}$ Krievvalodīgajā presē valdošā sajūsma par sankcijām bija indikators tam, ka liela daḷa Latvijas iedzīvotāju krīzes apstākḷos ir nostājušies kaiminvvalsts pusē. Tas radīja savstarpējas neuzticēšanās vilni Latvijas sabiedrībā un labvēlīgu augsni tālākai starpetniska konflikta eskalācijai, kas atbilda Maskavas interesēm.

Lai gan oficiāli sankcijas tā arī netika ieviestas, Kremlis lika lietā savus sakarus, lai de facto izdarītu spiedienu uz Latvijas ekonomiku. Tas tika panākts, izmantojot netiešus ietekmes instrumentus, piemēram, ārlietu ministra J. Primakova personīgos sakarus energētikas nozarē, Maskavas mēra Jurija Lužkova (Jurij Luzhkov) ietekmi biznesa aprindās un Kremlim pietuvinātus oligarhus, lai mudinātu uzṇēmumus pārtraukt sadarbību ar Latviju un boikotēt tās preces. ${ }^{61}$ Kaut arī ekonomiskās sankcijas bija acīmredzamas, Maskava, bažijoties par starptautiskās sabiedrības nosodījumu, to esamību vairākkārt noliedza.

Latvijas pusei neatlika nekas cits kā paust sašutumu un neizpratni par Krievijas lēmumu mērḳtiecīgi pasliktināt abu pušu attiecības. 5. martā Latvijas ĀM nāca klajā ar paziṇojumu, kurā mudināja Krievijas pusi pārstāt izteikt nepamatotus apvainojumus, savukārt iekšlietu resors, kas bija atbildīgs par 3. marta mìtina izgaiņāšanu, bija spiests atzīt, ka policija protestu apspiešanā izmantojusi stekus, taču tās darbību rezultātā nebija cietusi neviena persona. ${ }^{62} 6$. martā situāciju komentēja arī ārlietu ministrs V. Birkavs, kurš atzina, ka "pēdējo dienu notikumi ievelk melnu strīpu Latvijas un Krievijas attiecībās" un ka Maskava cenšas nomelnot Latviju. ${ }^{63}$ Reaǵējot uz Maskavas naidīgo propagandu, Latvijas ārlietu resors bija spiests uzsākt situācijas "skaidrošanas kampaṇu" Rietumvalstu un starptautisko organizāciju pārstāvju vidū. 9. martā ĀM oficiāli informēja EDSO, ASV un Eiropas Savienības valstu vēstniekus par aktualitātēm Latvijas attiecībās ar Krieviju. ${ }^{64}$

Pieaugot Krievijas spiedienam, Latvijas sabiedrībā izraisījās diskusija par iespējamiem krīzes orḳestrētājiem. Viens no sabiedrībā izplatītākajiem skaidrojumiem bija, ka krīzi ir izraisījusi Krievijas specdienestu iejaukšanās Latvijas iekšējās lietās. Ar šādu hipotēzi iepriekš bija atḷāvies spekulēt pat premjerministrs G. Krasts, taču Latvijas atbildīgie dienesti šãdu varbūtību neuztvēra nopietni. ${ }^{65}$ Par Krievijas specdienestu tiešu iejaukšanos trūka pierādījumu, turklāt šì naratīva tālāka attīstīšana oficiālā līmenī varēja radīt papildu spriedzi jau tā nestabilajās attiecībās ar Krieviju. Vēl viens sabiedrībā izplatīts krīzes skaidrojums tika 
saistīts ar 1997. gada nogalē no ieslodzījuma atbrīvoto bijušo Latvijas Komunistiskās partijas pirmo sekretāru Alfrēdu Rubiku. ${ }^{66}$ Politikis tika atbrīvots uz Oktobra revolūcijas 80. gadadienu, turklāt viṇa atbrīvošana notika neskaidros apstākl,os. ${ }^{67}$ A. Rubikam bija spēcīga ietekme laikrakstā Panorama Latvii, kas bija atbildīgs par 3. marta mītina organizēšanu - tas kḷuva par krīzes katalizatoru. ${ }^{68}$ Papildus tam A. Rubikam bija saglabājušies cieši politiskie sakari Krievijā. 1998. gada sākumā viņš ilgi viesojās Maskavā un tikās ar Maskavas mēru J. Lužkovu un Krievijas Komunistiskās partijas priekšsēdētāju Genādiju Zjuganovu (Genadij Zjuganov). ${ }^{69}$ Gan J. Lužkovs, gan G. Zjuganovs bija vieni no pirmajiem Krievijas politikiiem, kas mudināja Kremli vērsties pret Latviju, kā arī izcēlās ar l’oti asiem izteikumiem par Latviju, piemēram, J. Lužkovs bija salīdzinājis Latviju ar Pola Pota (Pol Pot) Kambodžu, ${ }^{70}$ savukārt G. Zjuganovs minējis, ka Latvijā norisinoties tas, kas nenotika pat aparteīda laikā Dienvidāfrikā. ${ }^{71}$

Papildus tam bažas radīja arī vairākas ar Krieviju saistītas radikāḷu organizācijas, kuras 1997. gada nogalē un 1998. gada sākumā bija aktivizējušās Latvijā. Piemēram, jau 1997. gada oktobrī Latvijas medijos parādījās informācija, ka Latvijā viesojies Krievijas labējo radikāḷu kustības "Krievu nacionālā vienotība" līderis Aleksandrs Barkašovs (Aleksandr Barkashov). ${ }^{72}$ Tāpat 1997. gada nogalē Latvijā slepeni it kā bija notikusi radikālā Krievijas politik̦a V. Žirinovska vadītās Liberāldemokrātu partijas spārna atklāšanas konference. ${ }^{73} \mathrm{~Pa}$ pildus tam šajā laika posmā bija aktivizējusies arī vietējā krievu kopiena - 1997. gada 9. oktobrī 17 organizācijas apvienojās un nodibināja jaunu biedrību "Krievu nacionālās kultūras autonomija". ${ }^{74}$ Vēl jo vairāk aizdomas radijja fakts, ka protesta akcijās 1998. gada pavasarī periodiski tika manīti arī nacionālboḷševiku partijas biedri.

\section{Leğionāru dienas faktors krīzes eskalācijā}

Par vienu no krīzes centrālajiem notikumiem kḷuva 16. marta leǵionāru dienas gājiens, kam īpašu uzmanību pievērsa vairāki Rietumvalstu mediji (piemēram, zviedru Expressen un Svenska Dagbladet, itālu Corriere della Sera, franču Le Figaro)..$^{75}$ Eiropas laikrakstos gājiens tika raksturots kā plaši apmeklēts, tā mērḳis esot holokausta noliegšana. ${ }^{76}$ Vairumā gadijjumu šāds leǵionāru dienas atspoguḷojums sakrita ar Krievijas propagandas interpretāciju. To apstiprina arī vēsturnieks A. Stranga, kura vērtējumā Rietumu un vietējās krievu preses reakcija uz 16. marta gājienu bija pārspīlēta un mākslīgi sakāpināta, jo, piemēram, 1997. gadā no 7000 Latvijā mītošajiem leǵionāriem uz pasākumu bija ieradušies tikai $250 .{ }^{77}$ Tomēr pirms 1998. gada gājiena ārvalstu medijos bija radīts tāds informatīvais fons, no kura varēja secināt, ka 16. marts ir teju vai viena no svarīgākajām piemiņas dienām Latvijā.

Kaut arī medijos bija sacelta ažiotāža, legionāru diena tika aizvadīta bez vērā n,emamiem starpgadījumiem. Par vienīgo incidentu parūpējās kāds krievvalodīgs pensionārs, kurš metās pūlī ar saukliem pret "fašismu" un pasākuma dalībniekus apmētāja ar burkānu šḳēlēm. Pensionāra līdzgaitnieki pamatā bija krievvalodīgi seniori, kurus pavadīja aptuveni 20 krieviski runājoši jaunieši. ${ }^{78}$

Rezultātā Latvijas pusei vislielākās galvassāpes radīja nevis iespējamās provokācijas no t. s. antifašistu puses, bet gan vairāku valsts amatpersonu dalība gājienā. Leǵionāru dienu, par spīti ārlietu un aizsardzības ministru aizliegumam, ${ }^{79}$ apmeklēja tādas augsta ranga amatpersonas kā Nacionālo brunoto spēku komandieris Juris Dalbiņš, armijas orḳestra vadītājs Dainis Uškāns, Jūras spēku komandieris Gaidis Zeibots, kā arī Saeimas deputāti Dzintars 
Ābiḳis, Oskars Grīgs, Pēteris Tabūns, Jānis Straume, Māris Kimenis un Aigars Jirgens. ${ }^{80}$

Latvijas amatpersonu attieksme pret dalību 16. marta pasākumos bija vērtējama kā vieglprātīga un ievērojami pasliktināja Latvijas pozīcijas konfliktā ar Maskavu. Vēsturnieks Uldis Neiburgs vēl pirms gājiena spekulēja, ka amatpersonas, iespējams, neapzinājās to, cik negatīvi legionāru gājiens ietekmēs Latvijas tēlu Rietumos, kā piemēru minot Satversmes aizsardzības biroja (SAB) direktora Laina Kamaldina nespēju objektīvi izvērtēt 16 . marta radītos riskus Latvijas tēlam ārzemēs. Neilgi pirms tam valsts galvenā specdienesta vadītājs kādā no intervijām bija minējis, ka 1998. gada gājiens ne ar ko neatškirsies no citiem gadiem, rezumējot: ja 15 večuku satiekas pie ugunskura un iedzer alinu - tad nekā nopietna tur nav. U. Neiburga vērtējumā ar vērā ṇemamām stratēǵiskās komunikācijas kḷūdām pirms gājiena bija izcēlies arī Valsts prezidenta padomnieks drošības jautājumos Guntars Zaḷaiskalns, kurš medijiem bija kḷūdaini apgalvojis: "G. Ulmanis neiebildìs pret to, ka Rìgā tiek plānota organizācijas Waffen SS 55 gadu jubileja". ${ }^{81}$

Augsta ranga valstsvīru piedalīšanās legionāru gājienā viennozīmīgi nāca par labu Krievijas centieniem diskreditēt Latviju Rietumvalstu vidū. Radīto reputācijas risku dēl prezidents 31. martā bija spiests izdot paziņojumu, kurā uzsvēra, ka Latvija ir demokrātiska valsts un tās amatpersonas nedrīkst piedalīties Waffen SS leg̣ionāru atceres pasākumos, savukārt komandieris J. Dalbiņš bija spiests atkāpties no ieņemamā amata. ${ }^{82}$

Kā jau bija paredzams, 16. marta gājienam sekoja asa Maskavas pretreakcija. Krievijas ĀM nāca klajā ar pazinojumu, ka Waffen SS leǵiona vēsture ir saistīta ar "tūkstošiem cilvēku asiṇu un ciešanām”, un apvainoja Latviju nacisma reabilitēšanā, ${ }^{83}$ savukārt Krievijas mediji izplatīja, iespējams, sagrozītu informāciju, ka 16. marta gājienu it kā īpaši asi nosodījuši arī Francijas prezidents Žaks Širaks (Jacques Chirac) un Vācijas kanclers Helmūts Kols (Helmut Kohl). ${ }^{84}$

Leǵionāru pieminas pasākumi atblāzmojās arī pašā Krievijā. 17. martā ar olām tika apmētāta Latvijas vēstniecība Maskavā. Sanākušie aicināja apcietināt Latvijas vēstnieku, savukārt vietējās varas iestādes kārtējo reizi ignorēja protestētāju radītos draudus vēstniecības darbiniekiem. Pasākumu kārtējo reizi organizēja kustība "Darba Krievija", kas pirms tam 9. martā pie konsulāta Pleskavā jau bija paspējusi sadedzināt Latvijas karogu, savukārt 13. martā, iespējams, draudējusi konsulātam ar teroraktu. ${ }^{85}$

Uzreiz pēc leğionāru dienas gājiena, 17. martā, Esplanādē tika aizvadīta krīzes laikā lielākā krievu kopienas protesta akcija. Tās oficiālais iemesls bija Latvijas valdības lēmums nepagarināt PSRS pasu derīguma termiṇu. Šis jautājums pamatā skāra Latvijas nepilsoṇus, no kuriem daudzi joprojām ikdienā izmantoja PSRS izdotās pases. Protesta akciju organizēja Kustība par sociālo taisnīgumu un līdztiesību Latvijā, tajā piedalījās arī politiskie spēki - Latvijas Sociālistiskā partija un Tautas Saskaņas partija. Kā ierasts, lielākā daḷa protestētāju bija krievvalodīgie pensionāri, kurus pavadīja neliela grupiņa jauniešu, kuri šoreiz sevi jau atklāti identificēja kā nacionālboḷševikus. Neṇemot vērā pasākuma masveidīgumu (Chas ziņoja, ka pasākumu apmeklēja 5000-7000 cilvēku, savukārt Panorama Latvii ${ }^{86}$ un $S M$ - līdz $10000^{87}$ ), tas aizritēja bez vērā ñemamiem starpgadījumiem. ${ }^{88}$ Vienīgā protesta akcijas daḷa, kas varēja pievērst uzmanību, bija nacionālboḷševiku klātbūtne. Kā novērojis laikraksts "Diena", nacionālbol̦ševiku aktīvisti šajā periodā bija klātesoši gandrīz katrā pret Latviju vērstajā mītiṇā Krievijā, turklāt pēdējos mēnešos to aktivitātes aizvien biežāk 
izgaismojās arī Latvijā, kur, pēc žurnālistu domām, mitinājās aptuveni 100 radikāḷu atbalstītāji. ${ }^{89}$

Paralēli plaši apmeklētiem mītiniem krīzes sākumposmā tika novērotas arī vairākas mazāka mēroga provokācijas, kuru mērkisis bija šķelt Latvijas sabiedrību. Piemēram, 10. martā prese ziņoja, ka ar nepiedienīgiem, pret latviešiem vērstiem saukliem esot apzīmēta 2. Rīgas pagarinātās dienas skola. Vandali netālu no skolas bija pakāruši kaki, pie kura piesprauduši uzrakstu, kurā draudēja izrēḳināties ar latviešiem. Par nodarījumu tika aizturēti četri krievu tautības jaunieši. Viens no tiem vēlāk atzinās, ka esot bijis nokaitināts, jo nelietīgie latvieši 3. martā situši pensionārus. ${ }^{90}$ Papildus tam neilgi pirms Leǵionāru dienas Latvijas mediju redzeslokā bija nonākušas pagrīdes organizācijas "Sarkanais koris" veidotas skrejlapas, kurās iedzīvotāji tika aicināti "pretoties sistēmai". ${ }^{91}$ Vēlāk skrejlapu saturs tika pārpublicēts arī pagrīdes laikrakstā General'naja Linija, kura izdevēji aicināja uz vardarbību pret buržujiem un tēlaini aprakstīja, kā līdz nāvei tiek nospārdīts valsts valodas inspektors. Kaut arī izdevumu saturs bija agresīvs un pretvalstisks, SAB direktora vietnieka Ulda Dzenīša vērtējumā tie draudus valsts drošỉbai neradīja. Vēl jo vairāk, pēc amatpersonas domām, Latvijai kā demokrātiskai valstij bija jāciena citādi domājošie iedzīvotāji. $^{92}$

Vēl viens protesta akciju vilnis notika Komunistiskā genocīda upuru piemiņas dienā 25. martā. Šoreiz mītiņos pie Krievijas diplomātiskajām pārstāvniecībām pulcējās latviski runājošā, nacionālistiski noskaņotā sabiedrības daḷ. Šiem mītiniem bija vēsturisks pamatojums, tomēr vietējā krievu prese tos interpretēja kā pierādījumu tam, ka Latvijas sabiedrībā valda nekontrolējams nacionālisms un rusofobija. Vietējais krievvalodīgais laikraksts $S M$ minēja, ka piketa dalībnieki ieradušies ar provokatīviem un cilvēkiem naidīgiem plakātiem, kas bijuši vērsti pret Latvijas krieviem. ${ }^{93}$ Savukārt Chas mìtinus aprakstīja kā "rusofobijas dienu", kurā piedalījās radikāl̦i un nacionālisti. ${ }^{94}$ Pasākumi aizritēja bez vērā ņemamām provokācijām, taču to laikā tika aizturētas divas personas, tostarp kāds jauns vīrietis, kas bija ar kāju iespēris vienai no piemiṇas brīža dalībniecēm. ${ }^{95}$

\section{Aprīịa spridzināšanas un citas provokācijas}

Kaut arī Krievijas un vietējie prokremliskie mediji centās dramatizēt situāciju Latvijā, 1998. gada martā netika novērots neviens vērā n,emams incidents, kas varētu noderēt kā iegansts tālākai krīzes eskalācijai. Situācija zināmā mērā mainījās 2. aprīlī, kad pie Rīgas sinagogas nogranda sprādziens. Tas bija katalizators jaunam no Krievijas orksestrētam propagandas vilnim, lai radìtu maldīgu priekšstatu par pieaugošiem terorisma draudiem Latvijā. Situāciju labāku nepadarīja arī tas, ka kopš 1995. gada šis bija jau trešais sprādziens, ko piedzīvoja Rīgas sinagoga. ${ }^{96}$

Sprādziens tika plaši atspogul,ots ne vien Krievijas, bet arī Rietumvalstu medijos. Krievijas propagandas mērkis bija sasaistīt sinagogas spridzināšanu ar marta notikumiem un Rietumvalstīs sliktu slavu ieguvušo leǵionāru gājienu. Neievērojot Krievijas centienus, Rietumvalstis bija mērenas savā vērtējumā un nesteidzās piekrist Maskavas propagandas naratīviem. Piemēram, ASV medijs Baltimore Sun skaidroja, ka situācija Latvijā ir neviennozīmīga un ir tieši saistīta ar valsts sarežǵito vēsturi un attiecībām ar Maskavu. ${ }^{97}$

Vēsturnieka A. Strangas vērtējumā Latvijas politiki apjauta, cik liels starptautisks skandāls var izvērsties, ja šī situācija netiks laikus atrisināta. ${ }^{98}$ Iespējams, tieši šì iemesla dēḷ Latvija nolēma nekavējoties 
lūgt ASV Federālā izmeklēšanas biroja palīdzību terorakta atklāšanā. ${ }^{99}$ Salīdzinājumā ar 3. marta mītiṇa izgaiṇāšanu Latvijas amatpersonu reakcija uz teroraktu un tā seku novēršana bija tūlītēja un konsekventa. Tika pieñemts lēmums nekavējoties veikt sinagogas remontu par Rīgas pašvaldības lìdzekḷiem, un apkārt sinagogai tika uzstādītas novērošanas kameras. ${ }^{100}$ Latvijas valdība publiski nosodīja teroraktu un steidzamības kārtā atstādināja no amata atbildīgo amatpersonu - Valsts policijas priekšnieku Aldi Lieljuksi. ${ }^{101}$ Galu galā Latvijas pusē nostājās arī sinagogas rabīns Natans Barkāns un Izraēlas vēstnieks Latvijā Odeds Ben-Hurs (Oded Ben-Hur), kurš bija spiests skaidrot, ka Latvijas sabiedrība nav antisemītiska un valstī neatdzimst fašisms. ${ }^{102}$

6. aprīlī Rìgu satricināja vēl viens sprādziens. Netālu no Krievijas vēstniecības ēkas uzsprāga kādā atkritumu tvertnē ievietota mīna. Lai gan sprādzienā nebija cietušo un tajā necieta vēstniecības ēka, provokācija pie Krievijas diplomātiskās pārstāvniecības izsauca kārtējo paniku prokremlisko mediju vidū. Laikraksts Chas sprādzienu aprakstīja kā pirmo starptautisko teroraktu Latvijas vēsturē ${ }^{-103}$ un spekulēja, ka sprādziens varētu negatīvi atsaukties uz Latvijas centieniem iestāties ES. ${ }^{104}$ Medijos radīto informatīvo fonu Rietumvalstis neṇēma vērā un sprādzienam nepievērsa īpašu uzmanību, apzinoties, ka tas neradīja reālus draudus vēstniecības darbiniekiem un, visticamāk, bija vērtējams kā sīka provokācija, lai pasliktinātu jau tā bēdīgā stāvoklī esošās Latvijas un Krievijas attiecības. Arī vēsturnieka A. Strangas vērtējumā abi minētie sprādzieni bija provokācijas, ar kuru palīdzību Maskavu atbalstošie radikāḷ centās mākslīgi saasināt situāciju Latvijā. ${ }^{105}$ Sagadīšanās pēc Krievijas vēstniecība jau krīzes sākumposmā bija nākusi klajā ar "pravietisku" brīdinājumu - tās rīcībā esot informācija, ka latviešu radikālās organizācijas plānojot veikt provokācijas pret kultūras un vēstures pieminekḷiem un Krievijas diplomātiskajām pārstāvniecībām. Vēstniecības ieskatā latviešu radikāḷi minētajās provokācijās plānoja nepamatoti apvainot Krieviju. ${ }^{106}$

Nākamajās dienās pēc spridzināšanām Rīgā krievvalodīgā prese aktīvi ziņoja par līdzīgām provokācijām arī citviet. Piemēram, 4. aprīlī Liepājā ar melnu krāsu tika apliets piemineklis holokausta upuriem. ${ }^{107}$ Laikraksts $S M$ ziņoja, ka reizē ar incidentu pie Krievijas vēstniecības sprādziens esot nograndis arī Valkas rajonā, netālu no Smiltenes. Lai gan trūka pierādījumu, krievu prese notikumu Vidzemes laukos interpretēja kā teroraktu un saistīja ar notikumiem galvaspilsētā. ${ }^{108} 8$. aprīlī krievu presē izplatījās ziņas, ka Rīgā kādā Valdeḳu ielas namā esot izkārts nacistiskās Vācijas karogs. Arī šai ziņai nepamatoti tika pievienota birka "terorisms". ${ }^{109} 11$. aprīlī spridzeklim līdzīgs priekšmets tika atrasts Rēzeknes naftas bāzē "Rēzna", savukārt policija bija saṇēmusi brīdinājumu par it kā Zaķusalas televīzijas tornī ievietotu bumbu. ${ }^{110}$

\section{Krīzes deeskalācija}

Aprīlī vērā ņemams saspīlējums bija iestājies arī Latvijas iekšpolitikā. Mēneša sākumā premjerministrs G. Krasts bija spiests atlaist Kremḷa biznesu lobējošās partijas "Saimnieks" ekonomikas ministru Ati Sausnīti saistībā ar panisko attieksmi pret Krievijas ieviestajām sankcijām. ${ }^{111}$ 8. aprīì̄ partija "Saimnieks", kuras kontrolē tobrīd bija četri ministru krēsli, paziņoja, ka izstājas no valdošās koalīcijas, tādā veidā draudot gāzt Latvijas valdību. Tiesa, neievērojot pamatīgu šūpošanos Saeimā, G. Krasts spēja konsolidēt ap sevi atlikušās koalīcijas partijas un noturēt varas grožus. ${ }^{112}$

Pēc nosacītas iekšpolitiskās krīzes pārvarēšanas par valsts galveno prioritāti kḷuva 
attiecību normalizēšana ar Krieviju un situācijas skaidrošana Rietumvalstu partneriem. G. Krasts krīzes radīto apstākḷu dēl atcēla ieplānoto vizīti uz ASV, savukārt prezidenta G. Ulmaņa vadībā tika izveidota darba grupa krīzes seku pārvarēšanai. Pie darba k̦ērās arī Latvijas likumdevēji, kas, sekojot ASV Prezidenta administrācijas ieteikumiem, pievērsās sasāpējušā nepilsoṇu jautājuma sakārtošanai. ${ }^{113}$ Rezultātā jau 15. aprīlì valdība bija apstiprinājusi rīcības plānu, kas paredzēja naturalizācijas logu atcelšanu.

Veiktie pasākumi pakāpeniski sāka dot cerēto efektu, un jau aprīḷa otrajā pusē krīzes atrisināšanā iesaistījās ASV: valsts sekretāre Madelēna Olbraita (Madeleine Albright) nosūtīja B. Jeḷcinam vēstuli ar brīdinājumu, ka pret Latviju ieviestās ekonomiskās sankcijas radīs negatīvas sekas. ${ }^{114}$ Īsā laika posmā Latvijai publisku atbalstu pauda arī citas ASV, Vācijas, EDSO un Baltijas jūras valstu padomes amatpersonas. ${ }^{115}$ Rietumvalstis pozitīvi vērtēja Latvijas valdības lēmumu reformēt arhaisko pilsonības likumu un aizvien stingrāk sāka nosodīt Krievijas ieviestās sankcijas.

Latvija beidzot guva pārliecību par Rietumu atbalstu un attiecībās ar Krieviju vairs nebija viena pati. Maskavai nebija izdevies izolēt Rīgu starptautiskajā arēnā, un Krievija bija spiesta atteikties no turpmāka tieša spiediena. Lai gan ekonomiskās sankcijas vēl kādu laiku palika spēkā, Latvijas un Krievijas attiecību krīzes izpausmes nākamajos mēnešos saruka līdz ierastajai negatīvajai retorikai.

Maskavas pozīciju mainu ietekmēja vairāki faktori.

- Pirmkārt, Krievija nespēja atrisināt samilzušo iekšpolitisko krīzi, kuras rezultātā 1998. gada 23. martā ar B. Jel̦cina ziņu tika atlaista V. Černomirdina valdība un Krievijas premjerministra pienākumu izpildīšana tika uzticēta uz ārpolitiku mazāk orientētajam Sergejam Kirijenko (Sergej Kirienko). ${ }^{116}$
- Otrkārt, Krievija turpināja slīgt aizvien dziḷākā ekonomikas krīzē. Vairākās nozarēs kavējās strādnieku algu izmaksa, un valstī draudēja izcelties iekšēji nemieri saistībā ar labklājības līmeṇa straujo krišanos. Maskavas lēmumu pieņēmējiem nācās secināt, ka Latvijas kā ārējā ienaidnieka tēls nav spējis novērst sabiedrības uzmanību no valsts iekšējām problēmām.

- Treškārt, Krievijas ieviestās ekonomiskās sankcijas kaitēja ne tikai Latvijas, bet arī pašas Krievijas jau tā nestabilajai ekonomikai un bija izraisījušas Rietumvalstu kritiku, kā rezultātā tika apdraudētas Maskavas starptautiskās pozīcijas.

Krievijas puse bija spiesta vismaz formālā līmenī atjaunot diplomātiskos sakarus ar Latviju. 23. aprīlī, piedaloties Latvijas ĀM valsts sekretāram Mārim Riekstinam un Krievijas ārlietu ministra vietniekam A. Avdejevam, Briselē notika pirmā abu pušu diplomātiskā tikšanās pēdējo divu mēnešu laikā. Latvijas un Krievijas attiecību krīze bija iegājusi nosacītā stabilitātes fāzē.

Tomēr iepriekšējo mēnešu pieredze lika domāt, ka Krievija varētu censties organizēt jaunas provokācijas gaidāmajos Uzvaras dienas pasākumos 9. maijā. Latvijas drošības iestādes bija mācījušās no iepriekš pieḷautajām kḷ̂udām un uz šo pasākumu laiku bija izstrādājušas īpašu darba režīmu, ${ }^{117}$ kā rezultātā 9. maija svinības notika bez liekiem incidentiem un tika aizvadìtas ierastajos toṇos - ar PSRS simboliku rotāti seniori turēja rokās A. Rubika un Josifa Stalina (Iosif Stalin) attēlus un periodiski izsauca saukḷus "fašismam - nē!" un "NATO - sliktāk nekā AIDS". ${ }^{118}$

14. maijā Rīgas centrā tika aizvadīta vēl viena Krievijas interesēm atbilstoša protesta akcija. Aptuveni 400-500 personas bija pulcējušās, lai paustu nepatiku pret Saeimas pienemto likumprojektu, kas 
paredzēja uzsākt pakāpenisku pāreju uz izglītību valsts valodā. Protesta akciju bija pieteikusi Latvijas Sociālistiskās partijas jauniešu nodaḷa, taču, kā mēḷja Latvijas prese, tās patiesie organizētāji slēpās nacionālboḷševiku rindās. Lai gan viens no radikāli noskan,otajiem krievu jauniešiem mītinā bija ieradies ar plakātu, kas vēstīja "nost ar latviešiem!", būtiskas provokācijas tā laikā izpalika. ${ }^{119}$

Latvijas ienemtais kurss uz stabilizāciju turpinājās arī starptautiskajā dimensijā. 1998. gada maijā M. Olbraita lika skaidri noprast, ka NATO vairs neņems vērā Krievijas intereses attiecībā uz Austrumeiropas valstu pievienošanos aliansei. ${ }^{120}$ Ar līdzīgu retoriku klajā nāca arī NATO runasvīrs Džimijs Šejs (Jimmy Shea), kurš apstiprināja, ka alianse turpinās savu paplašināšanās procesu un tas notiks "drīzāk agrāk, nekā vēlāk”, turklāt minot Latviju, Lietuvu un Igauniju kā potenciālās kandidātvalstis. ${ }^{121}$

Piekāpīgākās pozīcijās pret Maskavu joprojām atradās vecās Eiropas valstis, kuru ietekmes rezultātā ES noraidīja deklarāciju, kura rosināja nosodīt Krievijas sankcijas pret Latviju. ${ }^{122}$ Bija acīmredzams, ka Maskavas intereses Briselē joprojām lobēja Francija un Vācija, kas nevēlējās sabojāt attiecības ar Austrumu lielvalsti. ES nostāja attiecībā pret Krieviju sāka mainīties tikai jūlijā, kad Brisele bija spiesta atzìt, ka Maskavas pārmetumi Latvijai cilvēktiesību jomā ir bijuši nepamatoti.

Lai gan Maskava turpināja periodiski izteikt pārmetumus Latvijai, ar katru mēnesi pieaugošā ekonomiskā nestabilitāte traucēja tai saglabāt konsekventi augstu aktivitāti ārpolitikā. Vasaras izskaṇā ekonomiskā krīze, kas plosīja Krieviju, pakāpeniski tuvojās savam augstākajam punktam. Valstī strauji samazinājās Rietumu investīcijas, daudzās rūpniecības nozarēs apstājās algu izmaksas, reǵionos sāka parādīties spontānas pret režīmu vērstas protesta akcijas. Arī politiskajā līmenī Maskavā valdīja nestabilitāte. Krievijas VD bija klajā opozīcijā Kremlim, un Komunistiskā partija pieprasīja sākt prezidenta atstādināšanas procedūru. $^{123}$

Latvijas un Krievijas attiecību krīzei punktu pielika vasaras nogalē piedzīvotais Krievijas ekonomikas sabrukums. 17. augustā Maskava paziņoja, ka devalvē rubli, un bija spiesta lūgt Rietumvalstu ekonomisko palīdzību. Šādos apstākḷos Maskavai vienkārši nepietika finansējuma aktīvas ārpolitikas vešanai. ${ }^{124}$ Vēl jo vairāk, tā vairs nevarēja atḷauties riskēt sabojāt attiecības ar Rietumvalstīm, no kuru finansējuma bija atkarīga valsts tālākā nākotne. Maskavai neatlika nekas cits kā īslaicīgi pārtraukt lielāko dalu ārpolitisko afēru un koncentrēties uz samilzušo iekšējo problēmu risināšanu.

\section{Secinājumi}

Latvijas un Krievijas 1998. gada attiecību krīze ir uzskatāma par vienu no lielākajiem izaicinājumiem atjaunotās Latvijas vēsturē. Krīze satricināja Latvijas politisko eliti un sabiedrību, kā arī īslaicīgi radīja bažas par Latvijas eiroatlantiskās integrācijas procesa izdošanos. Par spīti pieredzētajām grūtībām, Latvijas puse no saspīlētās situācijas izgāja kā nosacìta uzvarētāja. Latvijas eiroatlantiskā integrācija netika būtiski traucēta, valstī saglabājās relatīva politiskā stabilitāte un etniskā konflikta iespējamība sevi pierādīja kā maz ticamu. Krievijas perspektīvā krīze nedeva cerētos rezultātus. Mākslīgi radītais Latvijas ārējā ienaidnieka tēls nebija pietiekams, lai novērstu sabiedrības uzmanību no straujā labklājības krituma. Vēl vairāk - Maskavas agresīvā ārpolitika iedragāja tās prestižu Rietumu partneru vidū.

Latvijas un Krievijas 1998. gada krīzes cēloṇus var nosacīti iedalīt vairākos virzienos. 
- Vēsturiski ideoloǵiskais virziens. Latvijas un Krievijas attiecības bija saspīlētas jau ilgi pirms 1997./1998. gada notikumiem. Abu pušu attiecību problemātikā centrālo lomu ieņēma atškirīga nostāja virknē aktuālu vēstures jautājumu, seviški saistībā ar Otro pasaules karu un padomju okupāciju. 20. gadsimta izskanāa šīs domstarpības kḷuva aizvien pamanāmākas un tika pastarpināti uzkurinātas ar Maskavas ziņu.

- Iekšpolitiskais virziens. Krievijas elitē bija nostiprinājies konservatīvs pasaules redzējums, kas uzstāja uz spēcīgu savas valsts interešu aizstāvēšanu. Maskavas tiešās interesēs bija izdarīt spiedienu uz kaimiņvalstīm, cerot gūt "diplomātisku uzvaru" uz brūkošās iekšpolitikas un ekonomikas fona. Savukārt Latvijā pie varas bija nākuši nacionālistiski noskaņoti politiķi, kuri nereti atklāti oponēja Krievijai un nerēķinājās ar tās interesēm.

- Sabiedriskais virziens. Latvijas sabiedrību raksturoja izteikta fragmentācija un vienotības trūkums. Galvenais šḳelšanās iemesls bija krievu minoritātes nespēja un/vai nevēlēšanās integrēties atjaunotajā Latvijas valstī. 1997./1998. gadā Latvijā aktualizējās virkne krievu kopienas vidū sevišķi jūtīgu jautājumu, piemēram, par nepilsoṇu statusu, leǵionāru piemiņas dienu, krievu valodas lietojumu un pāreju uz mācībām valsts valodā. Latvijas valdībai nelojālā krievu kopiena bija galvenais Maskavas instruments krīzes laikā.

- Ekonomiskais virziens. Pirmskrīzes un krīzes periodā Krievija saskārās ar vērā ṇemamu ekonomisko nestabilitāti, kā rezultātā strauji kritās iedzīvotāju ienākumu līmenis. Lai novērstu sabiedrības uzmanību no brūkošās ekonomikas,
Maskavai bija nepieciešams aktualizēt ārējā ienaidnieka tēlu, par kuru bija lemts kḷūt Latvijai. Vēl jo vairāk, pirmskrīzes periodā Latvijas valdība bija likusi noprast, ka tās plānos ietilpst Maskavas ekonomiskās ietekmes mazināšana, kas raisīja nepatiku Krievijas biznesa aprindās.

- Starptautiskais virziens. Pirmskrīzes periodā Maskavas lēmumu pieņēmēji bija satraukti par Vašingtonas un NATO aizvien uzstājīgāko tuvināšanos ar Baltijas valstīm. N̦emot vērā, ka Kremḷa gaiteņos bija nostiprinājušies pretrietumnieciski orientētie politiki, Maskava lēma par labu tam, lai pēc iespējas kavētu baltiešu eiroatlantiskās integrācijas procesu, destabilizējot situāciju Latvijā.

Lai gan publicētajos avotos nav pieejami tieši pierādījumi par to, ka aiz 1998. gada pavasarī pieredzētajām protesta akcijām un spridzināšanām stāvēja Krievija, var pieḷaut, ka vismaz pastarpināti tās varēja tikt īstenotas ar Maskavas ziņu. Krievijas rīcībā bija virkne ietekmes instrumentu, ar kuru palīdzību tā 1998. gada pavasarī varēja izdarīt spiedienu pret Latviju:

- Kremlim pietuvinātie oligarhi noderēja kā instruments, lai ieviestu pret Latviju vērstas ekonomiskās sankcijas, kā arī îstenotu propagandas kampaṇu to kontrolē esošajos medijos;

- Kremlim lojālās nevalstiskās organizācijas tika izmantotas, lai izplatītu dezinformāciju un diskreditētu Latviju starptautiskajā vidē;

- Maskavai lojālā krievu kopiena tika konsolidēta protesta akciju organizēšanai;

- Latvijā un Krievijā mītošie politiskie radikāḷi varēja tikt izmantoti dažādu provokāciju veikšanai. 


\section{ATSAUCES UN SKAIDROJUMI}

${ }^{1}$ ZANETA OzolinA. Crisis Prevention or Intervention: Latvia's Response to the Proposed Russian Security Guarantees. In: ERIC STERN, DAN HANSEN (eds.). Crisis Management in a Transitional Society. Stockholm 1999, p. 199.

2 Šajā periodā Latvija aktīvi iesaistījās NATO programmā "Partnerattiecības mieram", un Latvijas bruñotie spēki kopš 1996. gada piedalījās alianses operācijā Bosnijā un Hercegovinā.

${ }^{3}$ Aivars StrangA. The Relations Between Russia and the Baltic States: 1997-1998. Jahrbuch für internationale Sicherheitspolitik. Berlin 1999, p. 138.

${ }^{4}$ INESIS FELDMANIS, JĀNIS TAURĒNS. Latvijas ārpolitika un diplomātija 20. gadsimtā. 3. sēj. Rīga 2016, 116. lpp.

${ }^{5}$ Ibidem, 118. lpp.

${ }^{6}$ STRANGA, The Relations Between Russia and the Baltic States, pp. 138-139.

${ }^{7}$ Ibidem.

${ }^{8}$ Ibidem, p. 140.

${ }^{9}$ Madrid Declaration on Euro-Atlantic Security and Cooperation, 1997. Pieejams: https://www. NATO.int/docu/pr/1997/p97-081e.htm (skatīts 25.05.2018.).

${ }^{10}$ Against the Baltic's NATO bid. In: The Baltic Times, 11.-17.09.1997., p. 2.

${ }^{11}$ JĀNIS ŪDRIS. Šodien Viḷnā - Austrumeiropas valstu samits. In: Latvijas Vēstnesis, 05.09.1997. Pieejams: https://www.vestnesis.lv/ta/id/44771 (skatìts 24.05.2018.).

12 Ozolina, Crisis Prevention or Intervention, p. 194.

${ }^{13}$ Deklarācija par Ministru kabineta iecerēto darbību, 1997. Pieejams: https://mk.gov.lv/sites/ default/files/editor/krasts_deklaracija.pdf (skatīts 26.05.2018.).

${ }^{14}$ Alla PetropavlovsKaJA. Guntars Krasts: Ja verju v sebja. In: SM, 17.09.1997., s. 2.

${ }^{15}$ ĀRIS JANSONS. Pārmaiņas Kremlī. In: Diena, 23.09.1997., 2. lpp.

16 ÂRIS JANSONS. G̦eopolitikas ēna Krievijas prioritāšu meklējumos. In: Diena, 03.10.1997., 2. lpp.

${ }^{17}$ Pie Valsts prezidenta - Amerikas Savienoto Valstu politiḳis - Krievijas Federācijas vēstnieks. In: Latvijas Vēstnesis, 28.10.1997. Pieejams: https://www.vestnesis.lv/ta/id/30833 (skatīts 29.05.2018.).

${ }^{18}$ ANITA SMOḶENSKA. Būs viena ASV un Baltijas valstu harta. In: Diena, 15.10.1997., 1. lpp.

${ }^{19}$ Krievija, iespējams, cerēja uz Lietuvas atbalstu, ar kuru pirms drošības garantiju piedāvāšanas tika sekmīgi noslēgts robežlīgums.

${ }^{20}$ Stranga, The Relations Between Russia and the Baltic States, p. 142.

${ }^{21}$ Ozolina, Crisis Prevention or Intervention, p. 195.

${ }^{22}$ Aivars STRANGA. Baltic - Russian Relations 1998-99. In: ATIS LeJINS (ed.). Baltic Security Prospects at the Turn of $21^{\text {st }}$ Century. Helsinki 1999, p. 127.

${ }^{23}$ JURIS TiHonovs. Nesteidz ar atbildi Kremlim. In: Diena, 30.10.1997., 1. 1pp.

${ }^{24}$ STRANGA, The Relations Between Russia and the Baltic States, p. 141.

${ }^{25}$ Ozolina, Crisis Prevention or Intervention, p. 202.

${ }^{26}$ ROKAS TRACEVSKIS. Lithuania and Estonia reject Russian security guarantees. In: The Baltic Times, 06.-12.11.1997., p. 1.

${ }^{27}$ Ozolina, Crisis Prevention or Intervention, p. 197.

${ }^{28}$ Kto tam krassnij kommisar? In: SM, 06.11.1997., s. 2.

${ }^{29}$ JĀNIS LAUVA. Krievijā turpinās ažiotāža ap drošības garantijām. In: Neatkarīgā Rīta Avīze, 13.11.1997., 6. lpp.

${ }^{30}$ NELLIJA LOČMELE. Jeḷcins aicina veidot “uzticības režīmu” Baltijas reǵionā. In: Diena, 04.12.1997., 1. lpp.

${ }^{31}$ NeLliJA LoČMELE. Jeḷcins par Baltiju. In: Diena, 04.12.1997., 3. lpp.

32 PĀVels Širovs. Vai pēdējais Krievijas reformators? In: Diena, 24.11.1997., 4. 1pp. 
${ }^{33}$ Kremlis noliedz Jeḷcina saslimšanas saistību ar sirds problēmām. In: Diena, 12.12.1997., 9. lpp.

${ }^{34}$ PĀVELS ŠIrovs. Jaunais gads Krievijā nāk ar rubḷa denomināciju. In: Diena, 29.12.1997., 5. lpp.

${ }^{35}$ Konstantin KAZAKOv. Latvija poluchila priglashenie vtorogo sorta. In: Chas, 15.12.1997., s. 4.

${ }^{36}$ Partnerības harta starp Latvijas Republiku, Igaunijas Republiku, Lietuvas Republiku un Amerikas Savienotajām Valstīm. Pieejams: https://m.likumi.lv/doc.php?id=31233 (skatîts 09.06.2018.).

${ }^{37}$ Stranga, The Relations Between Russia and the Baltic States, p. 143.

${ }^{38}$ PĀVELS ŠIrovs. Krievija: harta ir drauds Eiropas drošībai. In: Diena, 21.01.1998., 1. lpp.

39 JURIS Tihonovs. Krievijas ĀM: PSRS neokupēja Baltijas valstis. In: Diena, 20.01.1998., 1. lpp.

40 JuRIS TiHonovs. Latvija atbildēšot Vizentāla centram. In: Diena, 21.01.1998., 1. lpp.

${ }^{41}$ DACE Plato. Krievu kultūras biedrības sūdzas Černomirdinam. In: Diena, 22.01.1998., 2. lpp.

${ }^{42}$ AIgARS ŠTĀLS, JuRIS TiHONOvS. Maskavas sociologi Latvijā pēta sabiedrības noskaņojumu. In: Diena, 19.01.1998., 4. lpp.

43 JuRIs Tihonovs. Krievijas sociologi bāzējušies fondā Drošība. In: Diena, 29.01.1998., 1. lpp.

${ }^{44}$ GunTIS ENIN̦Š. Latvijas Republikas 6. Saeimas ziemas sesijas piektā sēde, 12.11.1998. Pieejams: http://www.saeima.lv/steno/st_98/st1202.html (skatīts 10.06.2018.).

${ }^{45}$ Mitchell LANDSBerg. Yeltsin: Clinton risks World War III in Iraq. In: The Baltic Times, 12.-18.02.1998., p. 2.

${ }^{46}$ TANYA Neuman. Baltics offer help in Iraqi crisis. In: The Baltic Times, 26.02.1998., p. 1.

${ }^{47}$ INNA HARLANOva. Za poteri pust' platit vinovnyj. In: Panorama Latvii, 01.03.1998., s. 1.

${ }^{48}$ DitA ARĀJA, Edgars GAlzons. Piketētāji Valdemāra ielā bloḳē satiksmi. In: Diena, 04.03.1998., 3. lpp.

${ }^{49}$ Tracis pie Rīgas Domes. In: Neatkarīgā Rīta Avīze, 04.03.1998., 2. lpp.

${ }^{50}$ Aivars Stranga. The End Product: A Crisis in Latvian-Russian Relations. NATO 1999, p. 3.

${ }^{51}$ PĀVELS ŠIrovs, JuRIS TiHONOVs. Krievijas ĀM aicina pasaules sabiedrību nosodīt akciju Rīgā. In: Diena, 05.03.1998., 1.-3. lpp.

${ }^{52}$ STRANGA, Baltic - Russian Relations 1998-99, p. 130.

${ }^{53}$ SARMA KoČĀNE, INTA LASE. Krievija pel, policiju Latvijā. In: Diena, 05.03.1998., 1. lpp.

${ }^{54}$ Skandal'naja Slava. In: Chas, 06.03.1998., s. 2.

${ }^{55}$ EviJA OzolA. Krievijas nosodījums kḷūst aizvien skaḷāks. In: Neatkarīgā Rīta Avīze, 07.03.1998., 2. lpp.

${ }^{56}$ EviJA OzolA. Rīgas mītiņš izraisa plašu rezonansi. In: Neatkarīgā Rīta Avīze, 06.03.1998., 2. lpp.

57 ŠIrovs, TiHonovs, Krievijas ĀM aicina pasaules sabiedrību nosodīt akciju Rīgā, 1.-3. lpp.

${ }^{58}$ PĀVels ŠIrovs, JuRIS Tihonovs. Atceḷ Krievijas Valsts domes spīkera vizīti Latvijā. In: Diena, 07.03.1998., 1.-3. lpp.

${ }^{59}$ PĀVELS ŠIROVs, JURIS TiHONOvs. Krievija apsver sankcijas pret Latviju. In: Diena, 09.03.1998., 1. lpp.

${ }^{60}$ ABIK JELKIN. Sankcii Budut! In: SM, 10.03.1998., s. 1.

${ }^{61}$ STRANGA, Baltic - Russian Relations 1998-99, p. 133.

62 ŠIrovs, TiHONOvs, Krievijas ĀM aicina pasaules sabiedrību nosodīt akciju Rīgā, 1.-3. lpp.

${ }^{63}$ ŠIrovs, TiHonovs, Atcel Krievijas Valsts domes spīkera vizìti Latvijā, 1.-3. lpp.

${ }^{64}$ Nellija LoČMele, Baiba Rulle. Vēstniekam skaidro pie Rīgas domes notikušo. In: Diena, 10.03.1998., 1. lpp.

${ }^{65}$ EviJA OzolA. 3. marta pikets - vai provokācija. In: Neatkarīgā Rīta Avīze, 12.03.1998., 5. lpp.

${ }^{66}$ INGA PAPARDE. Tiesa atbrīvo Rubiku. In: Neatkarīgā Rīta Avīze, 07.11.1997., 1. lpp.

${ }^{67}$ JĀNIS BRŪKLENIS, AIVARS PASTALNIEKS. Neskaidrības ap Rubika atbrīvošanu. In: Neatkarīgā Rīta Avīze, 07.11.1997., 1. lpp.

${ }^{68}$ StrangA, The Relations Between Russia and the Baltic States, p. 146. 
${ }^{69}$ STRAnga, The End Product, p. 5.

${ }^{70}$ PĀvels ŠIrovs. Lužkovs Latviju salīdzina ar Kambodžu. Diena, 28.03.1998., 1. lpp.

${ }^{71}$ STRANGA, Baltic - Russian Relations 1998-99, p. 131.

${ }^{72}$ SANDRIS METUZĀLS. Latvijā pabijis krievu fašistu līderis? In: Neatkarīgā Rīta Avīze, 30.10.1997., 1. lpp.

${ }^{73}$ V. STREL'Cov. Rizhskie Vervol'fovichy. In: SM, 05.10.1997., s. 3.

${ }^{74}$ DACE Plato. Krievu diasporas apvienošanai Latvijā dibina jaunu organizāciju. In: Diena, 10.10.1997., 4. lpp.

${ }^{75}$ JURIS TiHONOvs. Pasaules prese turpina ziņot par leǵionāriem un nepilsoṇiem. In: Diena, 21.03.1998., 4. lpp.

${ }^{76}$ Evita Prokopova, Juris Tihonovs. Troksnis ap latviešu leğionāru svinībām. In: Diena, 04.03.1998., 3. lpp.

77 Daina Bleiere, Aivars Stranga. The Latvian Russian Crisis of 1998. In: Stern, Hansen, Crisis Management in a Transitional Society, p. 223.

78 Šogad leǵionu piemin saspringtā gaisotnē. In: Diena, 17.03.1998., 3. lpp.

${ }^{79}$ Bleiere, Stranga, The Latvian Russian Crisis of 1998, pp. 236-237.

${ }^{80}$ Vchera oni opozorili nashu stranu. In: Chas, 17.03.1998., s. 1.

${ }^{81}$ ULDIS NEIBURGS. SS, Waffen SS, latviešu leǵions un Latvijas valsts politika. In: Diena, 06.03.1998., 2. lpp.

82 Bleiere, Stranga, The Latvian Russian Crisis of 1998, p. 239.

83 Ibidem.

${ }^{84}$ Latvian Legion fallout: Kohl, Chirac condemn march. In: The Baltic Times, 02.-08.03.1998., p. 8.

${ }^{85}$ JuRIS TiHonovs. Latvijas vēstniecību apmētā ar olām. In: Diena, 17.03.1998., 1. lpp.

${ }^{86}$ BleiERE, Stranga, The Latvian Russian Crisis of 1998, p. 241.

${ }^{87}$ NATAL'JA LeBedEVA. Russkaja atmoda. In: SM, 18.03.1998., s. 1.

${ }^{88}$ Evita Prokopova, JuRis Tihonovs. Prasa pagarināt pasu derīgumu. In: Diena, 18.03.1998., 1.-3. lpp.

${ }^{89}$ Evita ProKopova. PĀVELS Širovs. Krievijas nacionālboľ̦̌eviki "izgaismojas" Latvijā. In: Diena, 20.03.1998., 4. lpp.

${ }^{90}$ Skolas apgānītāji aizturēti. In: Lauku Avīze, 14.03.1998., 3. lpp.

${ }^{91}$ JĀNIS VANAGS. Piketā aicina uz cīṇu nemaksājot rēḳinus. In: Diena, 17.03.1998., 1. lpp.

${ }^{92}$ MĀRIS Puk̦ītis. Revolucionārajai pagrīdei sava avīze. In: Lauku Avīze, 31.03.1998., 4. lpp.

${ }^{93}$ NATAL'JA LebedeVA. V kazhdom russkom v Latvii vidjat Stalina. In: SM, 26.03.1998., s. 1.

${ }^{94}$ Konstantin KazAKov, AleKSANDR Shunin. Den' neistovoj rusofobii. In: Chas, 26.03.1998., s. 2.

${ }^{95}$ EDGARS GALZONS. Iesper piemiņas brǐža dalībniecei. In: Diena, 26.03.1998., 8. lpp.

${ }^{96}$ Pirms tam sprādzieni bija notikuši 1995. gada pavasarī un 1997. gada nogalē.

${ }^{97}$ WiLl ENGLUND. Crimes of nazis and communists haunt Latvia bitter recriminations rooted in 1940s strain Moscow-Riga relations. In: Baltimore Sun, 05.04.1998. Pieejams: http://articles. baltimoresun.com/1998-04-05/news/1998095051_1_latvian-legion-russian-communism-russianminority (skatīts 19.06.2018.).

${ }^{98}$ Bleiere, Stranga, The Latvian Russian Crisis of 1998, p. 242.

${ }^{99}$ AleKsej Stefanov. FBR nachinaet rassledovanie. In: Chas, 06.04.1998., s. 2.

${ }^{100}$ Latvian police chief sacked over Riga synagogue bombing. In: BBC News, 02.04.1998. Pieejams: http://news.bbc.co.uk/2/hi/europe/72900.stm (skatīts 07.05.2018.).

${ }^{101}$ Bleiere, Stranga, The Latvian Russian Crisis of 1998, p. 242.

${ }^{102}$ Ibidem, p. 243. 
${ }^{103}$ Konstantin Kazakov, Aleksej Stefanov. Bomba: pod Rossiju? pod Latviju? In: Chas, 07.04.1998., s. 2.

${ }^{104}$ ALEKSANDR KRASNITSKIJ. Obraz Latvii. In: Chas, 07.04.1998., s. 1.

105 Bleiere, Stranga, The Latvian Russian Crisis of 1998, p. 241.

${ }^{106}$ SERGEJ BARDOvSKIJ. Riga zhdjot diversij. In: Chas, 14.03.1998., s. 2.

107 Aleksej Stefanov. Liepaja: Koshhunstvo na kladbishhe. In: Chas, 06.04.1998., s. 1.

${ }^{108}$ ANDREJ PORTnOV, VITA SHTEJN. Terakt, eshhjo terakt. In: SM, 07.04.1998., s. 1.

${ }^{109}$ Nas utro vstrechaet svastikoj. In: SM, 08.04.1998., s. 1.

${ }^{110}$ AleKSEJ Stefanov. Vzryv v Rezekne ne sostojalsja. In: Chas, 14.04.1998., s. 2.

${ }^{111}$ Bleiere, Stranga, The Latvian Russian Crisis of 1998, p. 228.

112 Ibidem.

${ }^{113}$ Ibidem.

${ }^{114}$ STEVEN ERLANGER. U.S. is trying to defuse a growing Russia-Latvia confrontation. In: The New York Times, 16.04.1998. Pieejams: https://www.nytimes.com/1998/04/16/world/us-is-trying-todefuse-a-growing-russia-latvia-confrontation.html (skatîts 20.06.2018.).

115 Bleiere, Stranga, The Latvian Russian Crisis of 1998, p. 228.

116 PĀVELS Širovs. Krievijā sastāda jaunu valdību. In: Diena, 24.03.1998., 1. lpp.

117 Bleiere, Stranga, The Latvian Russian Crisis of 1998, p. 253.

${ }^{118}$ DitA ARĀJA. Pārdaugavā svin Lielā Tēvijas kara beigu gadadienu. In: Diena, 11.05.1998., 4. lpp.

119 GunitA NAGLE, JuRIS TiHONOvs. Nacionālboḷševiki saliedē izglītības likumprojekta kritizētājus. In: Diena, 15.05.1998., 1.-4. lpp.

${ }^{120}$ Madelēna Olbraita. Pietiek satraukties par Krieviju. In: Diena, 05.05.1998., 2. lpp.

${ }^{121}$ KRISTĪNE PlAMŠE. NATO paplašināšana turpināšoties. In: Diena, 07.05.1998., 1. 1pp.

${ }^{122}$ KRISTĪNE PlAMŠE. ES runās ar Latviju un Krieviju. In: Diena, 06.05.1998., 1. lpp.

${ }^{123}$ FELdMAnIS, TAURĒNS, Latvijas ārpolitika un diplomātija 20. gadsimtā, 141. lpp.

${ }^{124}$ Konstantin Voronov. The Baltic Policy of New Russia: A Brief History of the Stormy Decade. In: TALAVs JunDZIS (ed.). The Baltic States at Historical Crossroads. Riga 2001, p. 500.

\section{SUMMARY}

The first signs of the growing crisis in Latvian-Russian relations were established already in early 1997. Russian foreign affairs of that time already showed that Kremlin has started work on development of new strategy regarding the Baltic states. In March 1997, during the US-Russian summit in Helsinki, Russian President Boris Yeltsin for the first time publicly announced that Russia would be ready to give security guarantees to the Baltics. During the next few months, the Russian political elite gradually secured the anti-Western sentiment and concerns about NATO enlargement process in post-Soviet space. Eventually, Moscow decided to increase pressure against the Baltic states in order to hamper the newly commenced Euro-Atlantic integration process.

In autumn 1997, Russian officials once more came out publicly with the idea of providing security guarantees to the Baltic states. In late October 1997, all three Baltic sister nations received an official draft project of security guarantees from the Russian Federation. It is highly unlikely that Moscow ever really hoped that the Baltic states would actually accept such proposal. Most likely, the main reason behind promises of security guarantees was the Russian intention to test the reaction of the West and discredit solidarity of the Baltic states. To a certain extent Moscow achieved its goals, 
since the Western countries were too inert regarding the idea of supporting the Baltic nations, meanwhile, indolence of Baltic politicians (especially of the Latvian ones) created the impression that Baltic states were too weak and unable to make proper decisions in crisis situation.

In late 1997, due to growing domestic problems, Russian foreign affairs activities regarding the Baltics slightly abated. Nevertheless, because of the straight course taken by the Baltics towards NATO and further Euro-Atlantic integration, the issue was put on Russian decision makers' agenda again. Kremlin reacted especially harshly to the charter of partnership among the USA and the Baltic states signed in the early 1998, and the support expressed by the Baltics to the Washington regarding the crisis in Iraq.

In comparison to other Baltic states, Latvia had the worst relations with Russia during that period of time. From the Moscow's perspective, power in Latvia was taken over by the nationalists who dared to object to Russian interests in international affairs and ignored the rights of the Russian minority residing in Latvia. The protest of pensioners by the Riga Council building on 3 March 1998 dispersed by the Latvian law-enforcement institutions exacerbated the crisis between both states. Already on the next day, the Kremlin launched a defamation campaign against Latvia to discredit it at international level and put in action unofficial economic sanctions.

In addition, the annual march of Waffen SS legionaries, which took place on 16 March in Latvia with participation of some state officials was also used by the Kremlin to discredit Latvia internationally. However, the Western countries avoided to publicly announce unconsidered decisions regarding the ongoing developments in Latvia. Furthermore, activities demonstrating Kremlin's influence did not result in any effect on domestic affairs of Latvia. Despite some protests, the overall situation within the country remained peaceful.

In April 1998, two IEDs exploded near the Riga Synagogue and the Russian Embassy. Russia attempted to use the explosions to destabilize the situation in Latvia. The Latvian officials, bearing in mind the previously made mistakes, successfully managed to avert the potential escalation of the crisis. In addition, during this period of time Latvia was able to retain a relative political stability. Eventually, Latvian political decision makers started to pay more attention to developing the state's foreign policy in order to explain the Western counterparts the delicate relations between Latvia and the Kremlin at the time.

In late spring and summer of 1998, the West finally provided Latvia with the urgently needed support by expressing criticism of Russia even more frequently, for the Kremlin had artificially created the crisis in relations between Latvia and the Russian Federation. Meanwhile, the economic situation in Russia continued to decline; eventually, on 17 August 1998 Moscow was forced to devalue the Russian rouble. In the advent of the economic crisis, the issue of Latvia disappeared from Kremlin's foreign policy agenda and the relations between both states gradually became stable. 


\section{Vēstures avoti}

Historical Sources 



\title{
Situācija Liepājā 1919. gada martā: Lietuvas tirdzniecības un rūpniecības ministra Jona Šimkus ziṇojums
}

\author{
Situation in Liepāja in March 1919: Report by Minister of Commerce and \\ Industry of Lithuania Jonas Šimkus
}

Dokumentu publicēšanai sagatavojuši, no lietuviešu valodas tulkojuši un komentējuši

Translation and commentaries by

Ëriks Jēkabsons, Dr. hist.

Latvijas Universitātes Vēstures un filozofijas fakultātes

Vēstures un arheoloğijas nodalas profesors

Aspazijas bulvāris 5, Rīga, LV-1050

E-pasts: eriks.jekabsons@lu.Iv

Edmunds Trumpa, Dr. philol.

Latvijas Universitātes Humanitāro zinātṇu fakultātes

Latvistikas un baltistikas nodalas asociētais profesors

Latvijas Universitātes Lituānistikas centra vadītājs

Visvalža iela 4a, Rīga, LV-1050

E-pasts: edmundas.trumpa@lu.Iv

1918. gadā visas Baltijas valstis proklamēja savu neatkarību Igaunija un Lietuva februārī, Latvija novembrī. Atškirībai laika ziṇā ir logisks izskaidrojums - Lietuva jau no 1915. gada pilnībā atradās vācu okupācijas varā, kas bija ieinteresēta zināma pretpoliska faktora pastāvēšanā, bet Igaunija vācu okupācijā nonāca tikai 1918. gada februārī, tomēr igauṇu elite paspēja proklamēt neatkarību pirms vācu karaspēka ienākšanas. Ne vienā, ne otrā valstī vācu okupācijas vara nepiel̦āva valstiskuma izveidošanos. Latvija vienīgā no visām Baltijas zemēm trīs gadus atradās tiešas karadarbības zonā, kurā nekāda plašāka sabiedriski politiska darbība, ieskaitot neatkarības proklamēšanu jebkādā formā pirms kara nobeiguma, nebija iespējama. Pēc kara beigām Rietumu frontē 1918. gada 11. novembrī stāvoklis krasi mainījās arī vācu karaspēka ieņemtajās teritorijās austrumos. Darbību sāka Lietuvas un Igaunijas nacionālā valdība, ko okupācijas varas iestādes pirms tam nepiel̦āva. 18. novembrī Rīgā proklamēja Latvijas Republiku, taču tās Pagaidu valdībai vēl bija jāizcīna vairāk nekā pusotru gadu ilga sarežgîita militāra un politiska cīṇa par valsts neatkarību un starptautisku atzī̌sanu. 1918.-1920. gadā Latvijas teritorijā sadūrās un visdažādākajās formās savstarpēji savijās topošās Latvijas 
Republikas, Padomju Krievijas un latviešu lielinieku (boḷševiku), vācbaltiešu, karā sakautās, pazemotās Vācijas, pretboḷ̌ševistiskās Krievijas, jauno un atjaunoto kaimiņvalstu Igaunijas, Lietuvas, Polijas, Somijas - un Rietumu lielvalstu intereses. Faktiski iekšējā un ārējā situācija tieši Latvijā 1919. gada pirmajos mēnešos bija sarežḡîtākā no Baltijas valstīm - Igaunijai izdevās atbrīvot savu teritoriju pirmajai, zināmā mērā stabilāks bija arī Lietuvas valdības stāvoklis.

1919. gada sākumā Latvijas Pagaidu valdība bija spiesta atstāt Rīgu, kuru ieñēma Sarkanā armija un kura uz vairākiem mēnešiem kḷuva par Padomju Latvijas galvaspilsētu. Valdība, kas šajā situācijā bija spiesta sadarboties ar vācu okupācijas spēkiem un vācbaltiešiem, atkāpās uz Liepāju, kur iespēju robežās turpināja darbību, cenšoties nostiprināt savu varu. Taču tam traucēja gan popularitātes trūkums, gan vācu okupācijas iestāžu neieinteresētība nodot varu Latvijas valdībai, kuras orientēšanās uz Rietumu lielvalstīm un iekšpolitiskie plāni attiecībā uz zemes reformu ne tām, ne vācbaltiešu elitei nevarēja izraisīt simpātijas. ${ }^{1}$

Jau no 1918. gada nogales Latvijas valdība īpašu vērību pievērsa tieši Lietuvai, to apliecina arī pirmā un pagaidām vienīgā pilntiesīgā diplomātiskā pārstāvja iecelšana Lietuvas galvaspilsētā Viḷnā - decembrī par Latvijas valdības pārstāvi Lietuvā kḷuva Vilis Bandrevičs (viņš pat ieradās Viḷnā, taču amatā nepaspēja stāties, jo tuvojās Sarkanā armija un Lietuvas valdība bēga no pilsētas, tāpēc 28. decembrī vinšs atgriezās Rīgā). ${ }^{2} 1919$. gada sākumā valdība centās nodibināt sakarus ar ārvalstīm - gan Parīzes miera konferencē, kur darbojās Latvijas un pārējo Baltijas valstu neoficiālas delegācijas, gan Rietumvalstu un kaimiņvalstu galvaspilsētās, uz kurieni devās Latvijas valstsvīri. Piemēram, 1919. gada februārī Ministru prezidents Kārlis Ulmanis un finanšu ministrs Spricis Paegle Stokholmā apspriedās ar Lietuvas valsts Padomes prezidentu Antanu Smetonu (Antanas Smetona) un finanšu ministru Martīnu Iču (Martynas Yčas), bet 28. februārī un 1. martā K. Ulmanis viesojās Kauñā, kur pēc sarunām parakstīja divus līgumus. Pirmais tika noslēgts ar Lietuvas Tirdzniecības un rūpniecības banku, un saskaņā ar to Latvijas valdība ieguva tiesības saņemt piecus miljonus Vācijas marku lielu aizdevumu uz vienu gadu no 100 miljoniem marku, ko Lietuvai 1918. gada beigās bija aizdevusi Vācija. Otrā līgumā Lietuvas valdība garantēja aizdevumu, iegūstot tiesības izmantot savām vajadzībām Liepājas ostu, kā arī novietot Liepājā kravu apsardzībai karaspēka nodaḷu. Turklāt puses apṇēmās sadarboties cīṇā pret Sarkano armiju. Ievērojot Latvijas Pagaidu valdības sarežgiito situāciju, šī palīdzība bija ārkārtīgi būtiska un l̦āva nodrošināt valdības iestāžu darbību. Arī Lietuvai vienošanās bija l,oti svarīga, jo vēl 7. maijā Lietuvas valdība konstatēja, ka "90\% Lietuvas tirdzniecības" iet caur Liepājas ostu (tās nonākšana boḷ̌̌eviku varā ietekmētu Lietuvu arī stratēgóiski). ${ }^{3}$

Burtiski nedēḷu pēc minēto līgumu parakstǐšanas Liepājā no Kauṇas cauri Austrumprūsijai (no Klaipēdas līdz Latvijas robežai - preču vagonā) ieradās plaša Lietuvas delegācija ar tirdzniecības un rūpniecības ministru Jonu Šimku (Jonas Šimkus, 1873-1944) priekšgalā. Tajā ietilpa arī pulkvežleitnants Mīkols Gedgauds (Mykolas Gedgaudas) no Apsardzības ministrijas (ar adjutantu Biḷūnu), inženieris Tads Šulcs (Tadas Šulcas) no Satiksmes ministrijas, ierēdnis Kruks no J. Šimkus vadītās ministrijas un agronoms Mīkols Baženskis (Mykolas Baženskis) no Pārtikas ministrijas, kā arī delegācijas sekretārs Rabinovičs. Vispārīgais uzdevums bija uz vietas noskaidrot informāciju par sadarbības iespējām, kā arī par Liepājas ostas izmantošanas organizāciju. 7. martā plkst. 13 delegāciju pieṇēma Ministru prezidents K. Ulmanis, pēc tam attiecīgo jomu pārstāvji runāja ar Latvijas amatpersonām. 
Prese īpaši uzsvēra, ka "daži no delegācijas locekḷiem runā arī latviski”" (vairāki bija dzīvojuši un mācījušies Latvijā - E. J.). 10. martā Latvijas valdības laikrakstā "Latvijas Sargs" tika publicēta plaša iepriekšējās dienas intervija ar J. Šimku, kurā viņš detalizēti aplūkoja Lietuvas situāciju, abu valstu attiecību nepieciešamību un perspektīvas, kā arī atzina, ka sarunā ar K. Ulmani īpaši interesējies par Latvijas valdības attiecībām ar Vācijas varas iestādēm Liepājā. ${ }^{5}$ Tāpat latviešu prese atzīmēja, ka sarunās abas puses guvušas "to labāko iespaidu", lietuvieši ierosinājuši arī pasta satiksmes nodibināšanu, un apspriests jautājums par drīzu diplomātisko pārstāvju apmaiṇu Liepājā un Kauñā. ${ }^{6}$

1919. gada jūlijā J. Šimkus automašīnā atkal ieradās Latvijā (viņš̌ Liepāju bija apmeklējis vairākas reizes arī Andrieva Niedras valdības varas laikā aprīlī-jūnijā, taču neveidoja ar to nekādus kontaktus, ko pats sevišksi uzsvēra), un latviešu prese īpaši atzīmēja, ka "šis Lietavas valstsvīrs bija pirmais, kas stājās tiešos sakaros ar Latvijas valdību Liepājā un atradās pirmās lietaviešu delegācijas priekšgalā, kura Liepāju apmeklēja marta sākumā". ${ }^{7}$

Publicējam J. Šimkus 1919. gada 9. martā rakstīto pārskata ziņojumu savai valdībai, kurā viņš dažas dienas pēc ierašanās samērā detalizēti apkopoja paša un citu delegācijas locekḷu iegūtās ziņas par vispārējo Latvijas politisko, militāro un sociālo situāciju. Tā kā Latvijas vēstures avotu klāsts par aplūkojamo periodu Liepājā nav liels, bet attiecību vēsturē ar Lietuvu par šo, faktiski pirmo, ārvalstu delegācijas vizīti Latvijā līdz šim nav zināms nekas, avots ir l̦oti nozīmīgs. Tajā sniegto informāciju ieguva Lietuvas delegācijas pārstāvji, un ne vienmēr tā ir precīza, taču J. Šimkus centās pēc iespējas objektīvi atspoguḷot situāciju, kādu redzēja Liepājā. Publikācijā sniegts dokuments oriǵinālvalodā (no Lietuvas Valsts arhīva Ārlietu ministrijas fonda) un dokumenta tulkojums, kas papildināts ar komentāriem.

\section{Dokumentas}

Prekybos ir Pramonès

Ministerija

9/III-19

Ponui Ministerių Kabineto Pirmininkui

Liepojus

Šimkaus bylon

Šiuomi turiu garbes pranešti Tamstai apie atliktus darbus mano komisijos Liepojuje.

Komisija Liepojun atvyko vos tik petnyčioje $7 /$ III šeštoje valandoje ryto; dviliktoje valandoje ta pačia diena komisija persistate Latvijos Ministerių Pirmininkui p. Ulmaniui, su kuriuo nutarta duot galemybes atskirių sričių atstovams susitikt su atstovais Latvijos delei pasitarimų. Pasitarime karininko Gedgaudo su Latvijos krašto apsaugos ministeriu \{civiliniu juristu Salit\} ir štabo viršininku \{kapitonu Plensneru\} surinktos sekančios žinios: prieš pasitraukiant iš Rigos Latvijos valdžia gruodzio menesyje pradejo tvert kariuomene iš savanoriu, persikelus ị Liepojų valdžia apskelbe priverstina mobilizacija kareivių tarpe 18-33 metų amžiaus ir karininkų lig i $45 \mathrm{~m}$. Dabartiniame momente kariuomene susideda iš penkių kuopų ir vieno eskadrono (išviso apie 1000 vyrų su atsarga) ant fronto ir iš vieno lavinamo bataljono atsargoje (apie 600 vyrų) Liepojuje, ị kurị ịplaukia mobilizuojami. Tam tikrų mokiklų nera, artilerijos nera, yra dvi vokiškos patrankos. Pažimetina, kad toje neskaitlingoje kariumeneje dalivauja ape 500 karininkų iš kuriu ant fronto yra sutverta 
viena atskira kuopa iš 80 asmenų. Podraug su šiuo latvių kariuomene organizuojas ir kariuomene iš vietinių vokiečių \{(jų skaičius apie 4000)\} biurgerių ir baronų iniciativa vietinių vokiškų dvarininkų; atskiros kuopos šitos kariuomenes nešioja vardus vietinių dvarininkų ir susideda, paviždžiui kuopoje kunigaikščio Liveno, iš ịvairių tautų, kurių tarpe yra rusai ir lietuviai, patekusiejie kaipo savanoriai; 13 lietuvių vieno eskadrono nor grižt Lietuvon; apart dvejų minetu kariuomenių Latvijoje veikia dar ir vokiečių freiwilligiai iš Vokietijos \{(jų skaičius Latvijoje apie 14000)\}. Frontas nuo bolševikų eina nuo juros šiauriu Vindavos 30 verstų paupiu Vindavos ant miesto Piltino, Goldingos, Vormeno, Frauenburgo, nuo kurio pasisuka ant Paupelu ir paupiu Vindavos lig Lietuvos rubežiui; iš pažimetų vietų Frauenburgas dar rankose bolševikų. Nuo Vindavos lig ị Vormeno veikia vietinių vokečių kariuomene (Landwehras), nuo Vormeno lig i Pampelnui - latvių ir toliaus germanai. Operativiniu vadu viso fronto yra vadas 6-to vokiečių-freiwilligiu korpuso generolas grafas Goltz, kuris vienija veikimą trijų atskirų kariuomenių, turinčių atskirus savo operativinius štabus. Latviai ginklų iš vokečių gavo mažai, dali didesnę gavo iš anglų, jųjų tarpe 50 šautuvų-kulkosvaidžių. Kulkosvaidžių latviai visai netur ir abelnai jaučias ginklų stoka; usisakyta ir manoma gaut iš anglų. Landweras vietinių vokečių apginkluotas pakankamai, jie tur ir kelias batarejas artilerijos, ginkluoja jos be kliučiu germanai freiwilligiai. Latvių kariuomene rubų tur dar neužtenkamai, o tie kurie tur deveja vokiškus. Kariuomene yra maitinama Latvių valdžios maistu gaunamu rekvizicijos keliu. Visoje Latvijoje karo stovis, rajonas Liepojaus visas kolei kas nemobilizuotas. Laiku paskutinios ofensivos prieš bolševikus latviai ir freiwilligiai nustoję rišių pripuolamai užpole vienį ant kitų rokuojant per apsirikimą bolševikais ir delei to nesusipratimo žuvo vadas latvių veikiančios ant fronto kariuomenes kapitonas Kalpokas su trimis aficeriais ir keletu freiwilligių. Kalpoko žuvimas padare didelị latviams nuostolį, nes tai buvo ižimiausias karininkas.

Iš pasitarimų agronomo p. Boženskio su viršininku latvių rekvizicijines komisijos p. Bliumbergu ape kariuomenes ir piliečių maitinimą surinktos šios žinios. Latvijos dvaldi ir miškai nesuliginamai geresneme stovije negu Lietuvoje, miškai buvo ekspolatojami pagal tikslaus miškų ūkio; jujų plotai užema trečdalį viso Kuršo ir remdamies savo miškais latvių atstovai Londone tikias net ant mišku gaut paskola. Baronų dvaruose germanai paliko kai kur net savaji turtą, kaip antai veisles arklius etc. Jei kur truko Kuršeje duonos, tai buvo vežama iš Lietuvos ir Šiaulių apskričio pašalinimui stokos. Freiwilligų kariuomene duona gauna iš Voketijos kitus gi produktus iš latvių valdžios už piningus. Veikia rekvizicijines Latvių komisijos, kurios nustatitomis kainomis, žemesnemis negu Lietuvoje, superka javus \{ir maistą apmokedamos rekvizicijų kvitais. Maitinimo klausimas sunkus ir maisto užteks ne daugiaus kaip vienam menesiui, nes maisto truksta kaip mieste teip ir pas kaimų gyventojus. Užsakyta Anglijoje Latvijai 50.000 tonų duonos ir 2.000 tonų riebalų, yra viltis už menesio gaut dalị užsakito.

Prekybos ir pramones atstovas Krukas surinko šias žinias.

Priekių del išvežimo iš Latvijos nera nei jokių, Liepojuje aukštomis kainomis reikalingi gyvenimui daiktai gaunami. I Liepojaus uostą labai retai atviksta laivai su priekemis, neseniai vienas laivas iš Švedijos Liepojaus uoste iškrauste 800 dežų su separatoriais kurių dalị galema pirkt (separatoriai turejo but iškrauti Gapsale).

Švedų draugija Runeberg gavo nuo Ententos tiesą isteigt reguliariškus reisus laivais du kartu i savaite tarp Liepojaus ir Stokholmo. Šiuo momentu ant reido uosto stovi trys kariški anglų mininkai. Uostas labai geras ir jame tilpsta dideli laivai su 25 pedu 
gilio. Uoste komerciškame yra daug sandelių, kuriuos galema lengviai gaut nuomon pas jų savininkus; jie visi yra dabar tuštus. Iš Liepojaus ị Kopenhagą yra kabelis privatiškos draugijos, kuriuo galema naudotis del susinešimo. Kolai kas Liepojaus uostai prigul nie Latvijos valdžiai o miesto savivaldybai, vienog valdžia mano jos paimt savo žinion neilgai trukus.

Susisiekimo Ministerijos atstovas inžinierius Šulcas pasitaręs su Latvijos Susisiekimo Ministeriu p. Hermanovskiu, kursai pildo pareigas \{ir\} ministerio prekybos ir pramones, surinko sekančias žinias. Užimtoje bolševiku puseje, rajone Valk-Riga-Daugpilis Latvijos valdžia dar prieš ateinant bolševikams iš vokečių, jiems pasitraukiant, pereme gelžkelius, du savaičiu eksploatavo kol jų neužeme bolševikai. Šiapus sienos visi keliai yra rankose vokečių ir latvių valdžia negal nustatyt laiko, kuomet pati valdyt prades. Prieš musų norą ateityje turet galemybe savo traukiniais pasiekt Liepojų latviai nieko netur, tik Latvijos Susisiekimo ministerija mano, kad Latvija isikurs visur pas save rusų platumo gelžkelị (jujų ekonomiški rišiai linkstą Rusios pusen daugiau negu kur kitur) ir tuomet negaledama naudotis musų keliu nuo Mažeikių lig Liepojaus tures isiteisyt \{paraleliškai\} savaji rusiškaji nuo Ringeno lig i Liepojaus, nes ne gal atsisakyt nuo palaikimo rišių tarp Rigos ir Liepojaus; atiduot kelių nuo Ventos lig ị Liepojaus musų vienų žinion latviai matyt ne mano. Gelžkelių dirbtuves Liepojuje ir laivų dirbtuves uoste akvačiai suteiktų mums pagelbos, kilus reikalui. Uostas su šleperiais ir visais kranais ir prietaisomis kolai kas prigul miesto savivaldybei, greitu laiku bus perimti Latvijos valdžios ir kilus reikalui Lietuvai naudotis bus suteikta galemybe; mažų laivų musų Nemuno reikalams nusipirkt če negalema. Latvijos Krasų Valdyba noret užmegzt su musų Krasų rišius, kad siuntinet korrespondencija ir kitus siuntinius \{Lietuvon\}. Kuomet atsiras faktiška galemybe siuntinet traukinius betarpiai iš Kauno ị Liepojų, reikes komisijoms latvių ir lietuvių tartis galutinai tarp saves ir vokiečiais delei galutinių sątikių ir nusistatimo mišrosę vietose ir pasirašyt po nutarimu atstovams. Latvių valdžia perimdama iš vokečių valdžios Liepojaus gelžkelių dirbtuves, pereme podraug 12 sugedusių garvežių ir kelesdešims priekinių vagonų; ta visa pasitaisę latviai tures pradžiai judinamajị-riedamaji materijalą tik lieka igyt kelią, kurị kolai kas vokečiai ne duoda ir nors eksploatuot patis karo siekiams.

Pereidamas prie bendro politiško stovio Latvijos turiu pranešti štai ką.

Latvijos laikinoji valdžia pasiremia ant turtingesnių latvių krašto gyventojų, jujų skaičius visgi yra mažumoje, nes net mažumiečiai valdžiai neužtiki, nekalbant jau apie didžiumiečius, kurių skaičius Liepojaus miesto savivaldyboje sutvere puse t. yra 40 asmenų iš 80 narių skaičiaus. Vokečiai biurgieriai turedami savo rankose visa prekyba ir pramone, nesutikdami su politika, kurią varo laikinoji Latvių valdžia, visgi jają pripažinsta ir palaiko ir net yra griežtai nusistatę prieš germanų politika Latvijoje. Vietiniai vokečiai dvarininkai savo simpatijoms linksta prie germanų ir tik baime už savo dvarus verčia jos kovot draugeje su latviais prieš didžiumiečius. Jie tur kariumene ir didesne ir geriau apginkluotą negu latvių kariumene ir šiuo momentu sunku permatyt kaip toji kariuomene bus sunaudota, pasibaigus kovai su bolševikais. Latvių valdžia yra dar pradedamoje fasoje organizacijos ir labai silpnai pildo \{darba\} daugalyje skyriuose ukio.

Dieną ankščiaus negu mes ị Liepojų atviko anglų komisija iš trijų narių delei ištirimo Latvijos stovio. Subatoje 8/III aš buvau priimtas komisijoje, kuriai įteikiau memoriala su parašu Ministerių Pirmininko ir du pranešimu su savo parašu apie dabartini stovi daliku Lietuvoje. Mano pasikalbejimas tęses 3 valandas. Komisija labai įdomavo organizacija valdžios Lietuvoje, ekonomišku padejimu krašto, organizacija kariuomenes ir frontu prieš 
bolševikus. Komisijos pirmininkas majoras Kenanas žadejo iš laivo per radio pranešt ape pasikalbejimą su manimi į Londoną o popierius išsiust laivu.

I mano pakvietima atvikt Kaunan akvačiai sutiko, pranešdamas, jog nevažiuosiąs pas mus per Voketija, todel pažadejau ji pasiimt už dvejų savaičių musų automobiliu ant ko jis sutiko. Panedelyje 10/III 10 valandoje ryto turiu komisijoje audiencija kartu su karininku Gedgaudu. Noriu gaut tiesa per komisija susinešt su Londonu ir gaut tiesa per Liepojaus uostą vardu Lietuvos valdžios atvežt maistą ir kitas priekes. Iš Liepojaus išvažiuosiu ketvirtadienyje 13/III 5 valandoje ryto. Klaipedoje susituresiu vienai dienai susipažint su uostu. Apsistosiu Hotele Unione.

Kiti nariai komisijos Šulcas, Gedgaudas ir Krukas četverge arba petnyčioje važiuos i Reveli ir Gelsingforsą.

Su pagarba Jonas Šimkus

\section{Dokuments}

Tirdzniecības un rūpniecības ministrija

9.III.1919

Liepāja

Ministru kabineta priekšsēdētāja kungam ${ }^{8}$

Uz Šimkus ${ }^{9}$ lietu

Ar šo man ir gods paziņot Jums par darbiem, kurus mana komisija veikusi Liepājā.

Komisija uz Liepāju atbrauca tikai piektdien, 7.III, plkst. sešos no rīta; tajā pašā dienā plkst. divpadsmitos komisija stādījās priekšā Latvijas Ministru prezidentam Ulmaņa ${ }^{10}$ k-gam, ar kuru panākta vienošanās dot iespēju atsevišku jomu pārstāvjiem tikties pārrunās ar Latvijas pārstāvjiem. Virsnieka Gedgauda ${ }^{11}$ sarunās ar Latvijas apsardzības ministru (civilo juristu Zālīti ${ }^{12}$ ) un štāba priekšnieku (kapteini Plensneru ${ }^{13}$ ) apkopotas šādas ziņas: pirms atkāpšanās no Rīgas Latvijas valdība decembrī sākusi veidot karaspēku no brīvprātīgajiem, pēc pārcelšanās uz Liepāju valdība izsludinājusi piespiedu mobilizāciju kareivjiem 18-33 gadu vecumā un virsniekiem līdz 45 g[adu] v[ecumam]. Pašlaik karaspēks sastāv no piecām rotām un viena eskadrona frontē (kopā ap 1000 vīru ar rezervi) un no viena mācību bataljona rezervē (ap 600 vīru) Liepājā, kur nokḷūst mobilizējamie. ${ }^{14}$ Konkrētu [kara] skolu nav, artilērijas nav, ir divi vācu lielgabali. Jāatzīmē, ka šajā skaita ziņā nelielajā karaspēkā ir apmēram 500 virsnieku, no kuriem frontē ir izveidota viena atsevišķa rota no 80 vīriem. Līdz ar latviešu karaspēku organizējas arī karaspēks no vietējiem vāciešiem (to skaits ap 4000) - birǵgeriem ${ }^{15}$ un baroniem - pēc vietējo vācu muižnieku iniciatīvas; atsevišķas šì karaspēka rotas tiek dēvētas vietējo muižnieku vārdos, un pastāv, piemēram, kṇaza Līvena ${ }^{16}$ rota, tajā ir dažādu tautu pārstāvji, starp viniiem ir krievi un lietuvieši, kas iestājušies kā brīvprātīgie; 13 lietuvieši no viena eskadrona vēlas atgriezties Lietuvā; bez diviem minētajiem karaspēkiem Latvijā darbojas vēl arī vācu brīvprātīgie algotņi [Freiwillige] no Vācijas (to skaits Latvijā ir ap 14 000). Boḷ̌seviku fronte iet no jūras uz ziemel̦iem no Ventspils 30 verstu gar Ventas krastu uz Pilteni, Kuldīgu, Vārmi, Saldu, no kurienes pagriežas uz Pampāliem un pa Ventas krastu iet līdz Lietuvas robežai; no atzīmētajām vietām Saldus vēl ir boḷ̌̌eviku rokās. No Ventspils līdz Vārmei atrodas vietējo vāciešu karaspēks (Landeswehr), no Vārmes līdz Pampāḷiem - latviešu [karaspēks] un tālāk vācieši. Visas frontes operatīvais virspavēlnieks ir 6. vācu-brīvprātīgo 
algotņu korpusa ${ }^{17}$ komandieris ǵenerālis grāfs Golcs, ${ }^{18}$ kura vadībai pakḷaujas trīs atsevišḳi karaspēki, no kuriem katram ir savs atseviškss operatīvais štābs. Latvieši no vāciešiem ir saņēmuši maz ieroču, lielāko daḷu tie dabūjuši no angḷiem, ieskaitot 50 patšautenes. Ložmetēju latviešiem nemaz nav, un vispār ir jūtams ieroču trūkums; tie ir pasūtīti un, domājams, tiks saṇemti no angḷiem. Vietējo vāciešu landesvērs ir apbruṇots pietiekami, viņiem ir vairākas artilērijas baterijas, viņus bez kavēšanās apbruṇo vācu brīvprātīgie algotņi. Latviešu karaspēkam vēl trūkst apgêerba, bet tie [karavīì], kuriem tas ir, valkā vācu formas. Karaspēks tiek barots ar latviešu valdības pārtiku, kas tiek iegūta rekvizīcijās. Visā Latvijā ir karastāvoklis, viss Liepājas rajons pagaidām nav mobilizēts. Pēdējā uzbrukumā bol̦ševikiem latvieši un brīvprātīgie algotṇi, zaudējot sakarus, nejauši uzbrukuši cits citam, kḷūdaini noturot otru pusi par boḷševikiem, un šī pārpratuma dēḷ gājis bojā frontē esošais latviešu karaspēka komandieris kapteinis Kalpaks ${ }^{19}$ ar trijiem virsniekiem un vairākiem brīvprātīgajiem algotn,iem. ${ }^{20}$ Kalpaka bojāeja nodarījusi latviešiem lielu zaudējumu, jo viņš bijis visievērojamākais virsnieks.

No agronoma Boženska ${ }^{21}$ k-ga pārrunām ar latviešu rekvizīcijas komisijas priekšnieku Blumberga ${ }^{22}$ k-gu par karaspēka un pilsoṇu ēdināšanu savāktas šādas ziņas. Latvijas muižas un meži ir nesalīdzināmi labākā stāvoklī nekā Lietuvā, meži tika izmantoti saskaņā ar precīziem mežu apsaimniekošanas principiem; to platība aizṇem trešo dalu visas Kurzemes, ${ }^{23}$ un, balstoties uz savām [lielajām] mežu platībām, latviešu pārstāvji Londonā pat cer pret mežiem saņemt aizdevumu. Baronu muižās vācieši dažviet atstājuši arī savu īpašumu, proti, vaislas zirgus utt. Ja kaut kur Kurzemē nebijis maizes, tad trūkuma novēršanai tā tika vesta no Lietuvas un Šauḷu apriṇka. Brīvprātīgo algotṇu karaspēks maizi saṇem no Vācijas, savukārt citus produktus - no latviešu valdības par naudu. Darbojas latviešu rekvizīcijas komisijas, kas saskaṇā ar noteiktajām cenām, kuras ir zemākas nekā Lietuvā, iepērk labību (un pārtiku), maksājot par to ar rekvizīciju kvītīm. Ėdināšanas jautājums ir smags, un pārtikas pietiks ne vairāk kā vienam mēnesim, jo pārtikas trūkst kā pilsētā, tā arī lauku iedzìvotājiem. Anglijā Latvijai ir pasūtīti 50000 tonnu maizes un 2000 tonnu tauku, ir cerība pēc mēneša saṇemt daḷu pasūtījuma.

Tirdzniecības un rūpniecības pārstāvis Kruks ${ }^{24}$ ir savācis šādas ziņas.

No Latvijas nav paredzēts izvest nekādas preces, Liepājā dzīvošanai nepieciešamās lietas par augstām cenām ir dabūjamas. Liepājas ostā ḷoti reti iebrauc kug̣i ar precēm, nesen viens kugíis no Zviedrijas Liepājas ostā izkrāva 800 kastes ar separatoriem, ${ }^{25}$ daḷ no tiem iespējams nopirkt (separatori bija jāizkrauj Hāpsalā).

Zviedru sabiedrība Runeberg ${ }^{26}$ ir saṇēmusi no Antantes tiesības nodibināt regulāros reisus ar kug̣iem divreiz nedēḷā starp Liepāju un Stokholmu. Pašlaik ostas reidā stāv trīs angḷu mīnu karakug̣i. ${ }^{27}$ Osta ir l, loti laba, un tajā var ienākt lieli kuği ar 25 pēdu iegrimi. Tirdzniecības ostā ir daudz noliktavu, kuras var viegli izīrēt no to īpašniekiem; tās visas pašlaik ir tukšas. No Liepājas uz Kopenhāgenu ievilkts privātas sabiedrības [telegrāfa] kabelis, kuru var izmantot sakariem..$^{28}$ Pagaidām Liepājas ostas pieder nevis Latvijas valdībai, bet pilsētas pašvaldībai, tomēr valdība domā drīz vien tās pārṇemt savā pārziṇā.

Satiksmes ministrijas pārstāvis inženieris Šulcs, ${ }^{29}$ apspriežoties ar Latvijas satiksmes ministru Hermanovska ${ }^{30}$ k-gu, kurš pilda (arī) tirdzniecības un rūpniecības ministra pienākumus, ir savācis šādas ziṇas. Boḷševiku ien̦emtajā daḷā Valkas-Rīgas-Daugavpils rajonā Latvijas valdība vēl pirms boḷševiku ienākšanas no vāciešiem, viṇiem atkāpjoties, ir pārn,ēmusi dzelzceḷus un divas nedēḷas tos ekspluatējusi, kamēr neienāca boḷševiki. Šaipus robežas visi ceḷi ir vācu rokās, un latviešu valdība nevar pateikt, kad pati tos pārṇems. 
Pret mūsu vēlmi nākotnē īstenot iespēju nodibināt savu vilcienu satiksmi ar Liepāju latvieši kategoriski neiebilst, vienīgi Latvijas Satiksmes ministrija uzskata, ka Latvija visur ierīkos dzelzceḷu ar krievu [lietotā] platuma [sliedēm] (viṇu ekonomiskie sakari sliecas uz Krievijas pusi vairāk nekā citur), un tad, nevarēdama izmantot mūsu ceḷu no Mažeikiiem līdz Liepājai, būs spiesta ierīkot (paralēli) savu krievisko [dzelzceḷu] no Reņgées līdz Liepājai, jo nevar atteikties no sakaru uzturēšanas starp Rīgu un Liepāju; atdot ceḷus no Ventas līdz Liepājai vienīgi mūsu uzraudzībā latvieši, šḳiet, negrasās. Ar dzelzceḷa darbnīcu Liepājā un kug̣u remonta darbnīcu ostā [viṇi] labprāt sniegtu mums palīdzību, ja rastos vajadzība. Osta ar velkoṇiem un visiem ceḷamkrāniem un iekārtām pagaidām pieder pilsētas pašvaldībai, tuvākā laikā tos pārṇems Latvijas valdība, un nepieciešamības gadījumā Lietuva varēs tos izmantot; mazos kuğus mūsu Nemunas vajadzībām nopirkt šeit nevar. Latvijas Pasta [un telegrāfa] pārvalde gribētu nodibināt sakarus ar mūsu Pastu, lai varētu nosūtìt korespondenci un citus sūtījumus (uz Lietuvu). Kad radīsies reāla iespēja nosūtīt vilcienus tieši no Kaunas uz Liepāju, latviešu un lietuviešu komisijām savā starpā un ar vāciešiem vajadzēs līdz galam vienoties par pēdējiem jautājumiem un nostāju strīdīgajos punktos un vienošanos parakstīt [abu pušu] pārstāvjiem. Latviešu valdība, pārṇemdama no vācu valdes Liepājas dzelzceḷu darbnīcas, pārṇēmusi arī 12 bojātas tvaika lokomotīves un vairākus desmitus preču vagonu; visu to salabojot, latviešiem sākumā būs kustošaisritošais [dzelzceḷa] sastāvs, atliek tikai iegūt dzelzceḷu, kuru vācieši pagaidām neatdod un vēlas ekspluatēt paši militārām vajadzībām.

Pārejot pie vispārējā Latvijas politiskā stāvokḷa, man ir jāpaziṇo, lūk, kas.

Latvijas Pagaidu valdība balstās uz turīgākajiem latviešu iedzīvotājiem, tomēr to ir mazākums, jo pat sīkzemnieki valdībai neuzticas, nerunājot jau par lieliniekiem, kuru skaits Liepājas pilsētas pašvaldībā veido pusi, t. i., 40 personas no 80 locekḷu skaita. ${ }^{31}$ Vācu birǵeri, turēdami savās rokās visu tirdzniecību un rūpniecību un nepiekrizdami politikai, kuru realizē latviešu Pagaidu valdība, tomēr to atzīst un atbalsta un pat ir stingri noskaņoti pret Vācijas politiku Latvijā. Vietējie vācu muižnieki simpatizē valstsvāciešiem, un tikai bailes par savām muižām piespiež viņus kopā ar latviešiem cīnīties pret lieliniekiem. Viṇu karaspēks ir gan lielāks, gan labāk apbruņots nekā latviešu karaspēks, un pagaidām ir grūti paredzēt, kā šis karaspēks tiks izmantots pēc cīņas beigām ar boḷ̌ševikiem. Latviešu valdība vēl atrodas organizācijas sākumstadijā un ḷoti vāji veic (darbu) daudzās saimniecības nozarēs.

Dienu agrāk nekā mēs Liepājā ieradās angḷu komisija ${ }^{32}$ trīs locekḷu sastāvā, lai izpētītu Latvijas stāvokli. Sestdien, 8.III, es tiku pieņemts komisijā, kurai iesniedzu memorandu ar [Lietuvas] Ministru prezidenta parakstu un divus ziņojumus ar savu parakstu par pašreizējo stāvokli Lietuvā. Mūsu saruna ilga 3 stundas. Komisiju l,oti interesējusi valdības organizācija Lietuvā, zemes ekonomiskais stāvoklis, karaspēka organizācija un fronte pret boḷševikiem. Komisijas priekšsēdētājs majors Kenans ${ }^{33}$ solījis no kuğa pa radio paziņot par sarunu ar mani Londonai, bet dokumentus nosūtīt ar kuĝ̣i.

Manam uzaicinājumam ierasties Kaunā [Kenans] labprāt piekrita, paziņojot, ka nebraukšot pie mums caur Vāciju, tāpēc es apsolīju viṇu pēc divām nedēḷām aizvest ar mūsu automobili, un viņš piekrita. Pirmdien, 10. III, plkst. 10 no rīta man ir pieņemšana komisijā kopā ar virsnieku Gedgaudu. Gribu saṇemt atḷauju ar komisijas starpniecību sazināties ar Londonu un atḷauju caur Liepājas ostu Lietuvas valdības vārdā atvest pārtiku un citas preces. No Liepājas izbraukšu ceturtdien, 13.III, plkst. 5 no rīta. Klaipēdā uzkavēšos vienu dienu, lai iepazìtos ar ostu. Apmetīšos viesnīcā Unione. 
Citi komisijas locekḷi, Šulcs, Gedgauds un Kruks, ceturtdien vai piektdien dosies uz Rēveli ${ }^{34}$ un Helsingforsu. ${ }^{35}$

Ar cieñu Jons Šimkus

Avots: Lietuvos Valstybinis Archyvas, 383-7-38, 1.-6. 1p. Rokraksts.

\section{ATSAUCES UN SKAIDROJUMI}

${ }^{1}$ Sīkāk par norisēm Latvijā aplūkojamajā periodā sk.: ĒRIKS JĒKABSONS, JĀNIS ŠILIN̦š (sast.). Cīṇa par brīvību: Latvijas Neatkarības karš (1918-1920) Latvijas Valsts vēstures arhīva dokumentos. 1. daḷa. 1918. gada 18. novembris - 1919. gada 16. aprīlis. Vēstures Avoti, X. Rīga 2019.

${ }^{2}$ Sk.: Latvijas Pagaidu valdības sēdes protokols, 28.12.1918. Latvijas Nacionālais arhīvs, Latvijas Valsts vēstures arhīvs, Rīga, 1313-1-1, 33. lp.

${ }^{3}$ Sīkāk par Latvijas un Lietuvas attiecībām aplūkojamajā laikā sk.: ĒRIKS JĒKABSONS. Latvijas attiecības ar Lietuvu 1919.-1921. gadā. In: Latvijas Vēsture 1997, Nr. 1, 85.-91. lpp.; Nr. 2, 25.-34. lpp.

${ }^{4}$ Sabiedroto un Lietaviešu delegācijas Liepājā. In: Latvijas Sargs, 08.03.1919., 6. lpp.

${ }^{5}$ Lietava un Latvija. In: Latvijas Sargs, 10.03.1919., 2. 1pp.

${ }^{6}$ Latviešu delegācija. In: Latvijas Sargs, 10.03.1919., 3. lpp.

${ }^{7}$ Saruna ar Lietavas tirdzniecības un rūpniecības ministru. In: Darbs, 17.07.1919., 4. lpp.

${ }^{8}$ Lietuvas valdības Ministru prezidents šajā laikā bija Mīkols Sleževičs (Mykolas Sleževičius; 1882-1939).

${ }^{9}$ Jons Šimkus (Jonas Šimkus; 1873-1944), Lietuvas kīmiḳis un valstsvīrs, mācījies ǵimnāzijā Liepājā. 1918. gada decembrī - 1919. gada 12. martā un aprīìi-oktobrī tirdzniecības un rūpniecības ministrs, 1921.-1922. gadā aizsardzības ministrs, vēlāk Kauņas Universitātes rektors. No 1924. gada arī Lietuviešu-latviešu tuvināšanās biedrības priekšsēdētājs.

${ }^{10}$ Kārlis Ulmanis (1877-1942), valstsvīrs. 1918. gada 17. novembrī - 1921. gadā Latvijas Pagaidu valdības Ministru prezidents.

${ }^{11}$ Mīkols Gedgauds (Mykolas Gedgaudas; 1885-1942), Lietuvas armijas virsnieks, pulkvežleitnants, vēlāk pulkvedis. 1919. gada janvārī-maijā Zemes apsardzības ministrijas Apgādes daḷas Artilērijas nodaļas priekšnieks, vēlāk pulka komandieris. Miris padomju ieslodzījumā.

12 Jānis Zālītis (1874-1919), advokāts, valstsvīrs. 1912.-1917. gadā Krievijas Valsts domes deputāts. 1918. gada decembrī - 1919. gada jūlijā Latvijas Pagaidu valdības apsardzības ministrs.

${ }^{13}$ Aleksandrs Plensners (1892-1984), virsnieks. 1918. gada 21. novembrī iestājās Latvijas Pagaidu valdības dienestā (kapteinis), no 11. decembra Apsardzības ministrijas Galvenā štāba G̦enerālštāba 1. nodaḷas (Organizācijas nodaḷas) priekšnieks (no 31. decembra G̣enerālštāba priekšnieka vietas izpildītājs).

${ }^{14}$ Ziṇojuma autors neierēḳina skaiț̣os Igaunijas armijas sastāvā esošās Latvijas Pagaidu valdības vienības.

${ }^{15}$ Birğeri - domāti pilsētnieki.

${ }^{16}$ Anatols fon Lĩvens (1873-1937), kṇazs (firsts), Mežotnes muižas īpašnieks, virsnieks. 1919. gada janvārī-jūnijā landesvēra krievu nodaḷas komandieris, pēc 16. aprīḷa apvērsuma atteicās no piedāvātā direktorāta locekḷa amata.

${ }^{17}$ Runa ir par Vācijas armijas 6. rezerves korpusu.

${ }^{18}$ Rīdigers fon der Golcs (Rüdiger von der Goltz; 1865-1946), Vācijas armijas virsnieks, ǵenerālmajors. Pirmā pasaules kara laikā karoja Austrumu un Rietumu frontē. 1918. gadā komandēja vācu 
ekspedīcijas karaspēku Somijā, Somijas Pilsoṇu kara dalībnieks. 1919. gada 1. februārī ieradās Liepājā, uzṇemoties Vācijas armijas 6. rezerves korpusa komandiera un Liepājas gubernatora amatu; oktobrī Vācijas valdība atsauca R. fon der Golcu no Latvijas.

${ }^{19}$ Oskars Kalpaks (arī Kolpaks; 1882-1919), virsnieks, pulkvedis, no 1918. gada decembra Pagaidu valdības brunotajos spēkos; no 31. decembra Latvijas zemessardzes visu latviešu vienību komandieris. No 1919. gada janvāra 1. latviešu atsevišḳā bataljona komandieris. Kritis 1919. gada 6. martā.

${ }^{20}$ Kopā ar O. Kalpaku krita kapteinis Nikolajs Grundmanis, virsleitnants Pēteris Krievs un piekomandētais vācu leitnants Hanss Šrēders.

${ }^{21}$ Mīkols Bažensks (Mykolas Baženskis), agronoms, no 20. gadsimta sākuma Burbišku muižas īpašnieks Radvilišķes apriņkī, pārvērta to par paraugsaimniecību.

22 Jānis Blumbergs (1886-1941), valstsvīrs. Latvijas Pagaidu valdības apgādības (pārtikas) ministra biedrs (1918-1919; 1919), arī apgādības ministrs (1919; 1919-1920).

${ }^{23}$ Domāta Kurzemes guberņa, resp., Kurzeme un Zemgale.

${ }^{24}$ Ierēdṇa Kruka (Krukas) personību pagaidām nav izdevies noskaidrot.

${ }^{25}$ Jādomā, runa ir par piena separatoriem.

${ }^{26}$ 1919. gada pirmajos mēnešos satiksmi starp Stokholmu un Liepāju uzturēja zviedru pasažieru tvaikonis Runeborg.

${ }^{27}$ Britu karakug̣i, ar kuriem ieradās arī Militārā misija, iebrauca Liepājas ostā 6. martā.

${ }^{28}$ Runa ir par Dānijas "Ziemeḷu" telegrāfa sabiedrību. Tās kabelis no Liepājas uz Kopenhāgenu 1919. gada pirmajā pusē faktiski veidoja vienīgo tiešo sakaru iespēju ar Eiropas valstīm.

${ }^{29}$ Tads Šulcs (Tadas Šulcas; 1880-1940), Lietuvas inženieris-konstruktors. Bērnību pavadījis un mācījies Liepājā, studējis Rīgas Politehniskajā institūtā. No 1918. gada Lietuvas valsts dienestā.

${ }^{30}$ Teodors Hermanovskis (1883-1964), inženieris, valstsvīrs. 1918.-1919. gadā Latvijas Pagaidu valdības satiksmes un darba ministrs. 1919. gada janvārī-februārī pildīja arī tieslietu, finanšu, tirdzniecības un rūpniecības un zemkopības ministra pienākumus.

${ }^{31}$ Runa ir nevis par boḷševikiem (lieliniekiem), bet par Latvijas Sociāldemokrātiskās strādnieku partijas biedriem.

${ }^{32}$ Runa ir par Lielbritānijas Militāro misiju Baltijas valstīs.

33 Ostins Kīnens (Austin Keenan; 1887-1957), Lielbritānijas armijas majors, no 1919. gada marta Militārās misijas Baltijas valstīs vadītājs, 1919. gada vasarā - 1920. gadā misijas vadītāja vietnieks.

${ }^{34}$ Rēvele - Tallina.

${ }^{35}$ Helsingforsa - Helsinki. 
Recenzijas

Reviews 



\section{Latvijas diplomāti par mūsu ārpolitikas simtgadi}

Recenzija par grāmatu: Mārtiņš Drēğeris (sast.). Latvijas diplomātijas gadsimts. Latvijas diplomātijas un ārlietu dienesta pirmais gadsimts (1919-2019) diplomātu esejās. Rīga 2020. 606 Ipp. ISBN 978-9934-0-8820-9

Jānis Taurēns

LATSUAS DIPLOMITIJAS UN ARLIETC DIENEST PIRMAIS GADSIMTS (1919-2019) DIPLOJIITU ESEJT̃

Aizvadītā Latvijas neatkarības simtgade radīja pašsaprotamu vēlmi atskatīties uz simts gados paveikto. Ārpolitika vienmēr bijusi nesaraujami saistīta ar Latvijas Republikas likteni laiku lokos. Ne vienmēr mūsu tautai ir izdevies lemt savu likteni pašai, tomēr nu jau vairāk nekā puse gadsimta ir aizvadīta neatkarības apstāklıs.

2020. gadā nāca klajā diplomāta un jurista Mārtina Drēgéra iniciētā un sastādītā 606 lappuses biezā grāmata "Latvijas diplomātijas gadsimts", tā sastāv no M. Drēgera priekšvārda un 26 nodaḷām, kuras drīzāk būtu jāsauc par rakstiem vai, kā izvēlējušies teikt paši autori, - par esejām. Grāmatā ievietoti vairāki vēsturiski pārskati par 
ārpolitikas norisēm pagātnē un diplomātu esejas par valsts mūsdienu ārpolitikas problēmjautājumiem. İsā ievadā ārlietu ministrs Edgars Rinkēvičs īpaši uzsver, ka Latvijas ārpolitiskās koncepcijas pamatā jābūt orientācijai uz Rietumiem: "Latvijai skaidri un neapšaubāmi jāpozicionējas kā Rietumu civilizācijas sastāvdalıi" (17. lpp.).

Grāmatā ievietota arī hronoloǵiska tabula par galvenajiem notikumiem Latvijas ārpolitikā, to sastādījuši Valdis Rūsiņš un Gints Apals. Diemžēl 30 gadus ilgajam periodam kopš neatkarības atjaunošanas veltītas tikai nepilnas trīs lappuses, un, piemēram, laikā no 2008. līdz 2013. gadam nav noticis gluži nekas ievērības cienīgs, lai gan tas neliekas pamatoti.

Pie vēsturiskajiem pārskatiem jāmin Ginta Apala raksts par valsts ārpolitiku starpkaru periodā, Argitas Daudzes pārskats par Latvijas diplomātisko dienestu okupācijas periodā un paša M. Drēgera apcerējums par personībām Latvijas ārlietu dienestā. Grāmata iepriecina vēsturnieka sirdi arī tajā ziṇā, ka vairākkārt uzsver Latvijas Universitātes Vēstures un filozofijas fakultātes mācībspēku un studentu devumu Latvijas ārlietu dienestam pēc neatkarības atjaunošanas (Alberts Sarkanis 147. lpp. un Mārtiņš Drēgeris 535 lpp.). Vispārinot varētu teikt, ka Latvijas ārpolitika un vēsture ir cieši saistītas gan filozofiskā, gan konkrētu personību līmenī. Protams, šī nav vienīgā Ārlietu ministrijas sagatavotā grāmata. Īpaši jāatzīmē diplomātu eseju (atmiṇu) krājums, kas iznāca pirms dažiem gadiem. $^{1}$

Uzmanību piesaista G. Apala pārskats par valsts ārpolitiku pirms Otrā pasaules kara. Autors ḷoti kritiski vērtē valsts ārpolitiku kara priekšvakarā, norādot uz Baltijas Antantes vājumu un nespēju izškirīịi rīkoties kritiskajā pirmskara situācijā. Arī Baltijas valstu neitralitātes politiku G. Apals pamatoti vērtē kā neadekvātu. Vai Latvijai bija kāda ārpolitiska alternatīva
1939.-1940. gada trag̣ēdijai? Katrā gadījumā tā nebija meklējama Krievijā. "Nepietiekama izpratne par komunistiskā režìma totalitāro raksturu deva pamatu ilūzijām par iespēju saglabāt" ierobežotu neatkarību vai zināmu autonomiju (61. lpp.). Vēstures literatūrā ir spilgti izteikts uzskats: "Lai kādi arī nebūtu bijuši Latvijas ārpolitikas un diplomātijas trūkumi vai stiprās puses, diplomātiskā cel̦ā Latvijas drošỉba vispār nebija nodrošināma."

Vēstniece Argita Daudze pievērsusies Latvijas diplomātijas un trimdas organizāciju darbībai okupācijas periodā. Vina atzīmējusi šo diplomātu un organizāciju lomu Baltijā, īpaši uzsverot ASV nostāju, gan būdama pietiekami kritiska pret Rietumu politiku. A. Daudze atzīmē, ka šis periods prasīja "gan pacietibu, gan elastibu no baltiešiem, lai [...] uzturētu spēkā prasību par okupācijas izbeigšanu" (82. lpp.). Mārtinsš Drēgéris apṇēmies portretēt personības Latvijas diplomātiskā dienesta vēsturē. Protams, gan 1919., gan 1991. gadā bija līdzīgas problēmas - Ārlietu ministrija bija jāveido no jauna. Abos gadījumos liela loma bija humanitāro zinātṇu speciālistiem (502., 535. lpp.), un abos gadījumos sākumā trūka atbilstoša atalgojuma. Interesants aspekts esejā ir diplomāšu lomas atspogul,ojums ārpolitiskajā dienestā. Esejā plaši aplūkota atsevišķu diplomātu darbība, reizēm pat pārāk plaši, piemēram, Miķel̦a Valtera ieguldījums apskatīts no 508. līdz 512. lappusei, savukārt, rakstot par mūsdienu diplomātiem, tekstā dominē plašs personu uzskaitījums bez izvērstāka apskata, kas droši vien pamatoti atstāts tagadnes un nākotnes vēsturniekiem.

Apcerējumiem par Latvijas mūsdienu ārpolitiku ir l,oti prominenti autori. Publicistiskajā literatūrā atzīmēta vairāku grāmatas autoru svarīgā loma Latvijas eiroatlantiskajā integrācijā, piemēram, gatavojot NATO samitu. ${ }^{3}$ Vairākiem autoriem ir nenovērtējama nozīme Latvijas neatkarības 
atjaunošanā, tās starptautiskajā atzīšanā un ārlietu dienesta izveidē.

Autoru vidū ir trīs ārlietu ministri (Sandra Kalniete, Māris Riekstiņš un Edgars Rinkēvičs), daudzi vēstnieki un citi ietekmīgi diplomāti. Šo rakstu tematika skar galvenos ārpolitikas virzienus, piemēram, Latvijas integrāciju Eiropas Savienībā (Eduards Stiprais, 185.-208. lpp.), attiecības ar ASV (Ilgvars Kḷava, 241.-268. 1pp.) un attiecības ar Krieviju (Gunda Reire, 287.-306. lpp.).

Ilgvara Kḷavas rakstā par attiecībām ar ASV ir vairāki konceptuāli interesanti aspekti, piemēram, viņš uzsver, ka Latvijas ārpolitika 90. gados bija "stingri sakṇota reālismā”, ko noteica valsts vēsturiskā pieredze, Krievijas armijas izvešanas procesa pieredze, ǵeopolitiskā situācija. Latviju nevarēja glābt "ANO vai EDSO vai Eiropas Padome" (250. lpp.), bet droša izvēle bija tikai "pievienošanās NATO militārajai aliansei, kurā ASV spēlē vadošu lomu" (251. lpp.). Kopumā autors augstu vērtē ASV nozìmi Latvijas drošības nostiprināšanā, norādot uz konkrētiem lēmumiem NATO paplašināšanās procesā 90. gados. No raksta uzzinām, ka īsu brīdi pēc "Krievijas militārās agresijas" sākuma pret Ukrainu ASV gaisa spēku elementi dažu stundu laikā tika pārvietoti atbilstoši jaunajai situācijai (264. lpp.). I. Kḷava tomēr kritiski vērtē atslābumu, kas iestājās Latvijas ārpolitikā pēc uzṇemšanas NATO. Pazīmes, kas liecināja par nepatīkamām pārmaiṇām jau kopš Krievijas un Gruzijas kara 2008. gadā, netika pienācīgi novērtētas.

Gunda Reire analizējusi Latvijas un Krievijas attiecību dinamiku. Izejas punkts, no kura būtu jāsāk Krievijas politikas analīze, pētniecei ir atziṇa, ka Krievijas cel̦š balstīts "uz padomju sentimentu, piepilditu ar imperiālistisku garu un mērḳi atgūt savu superlielvaras statusu, ideologisko dominanci un kontroli ārpus valsts robežām". Savukārt Latvijas uzdevumi ir sarežgīti, tiem raksturīga gan "ciña pret Krievijas ǵeopolitisko ietekmi, gan vēlme veidot noturïgas diplomātiskas attiecỉbas" (290. lpp.).

Šo rindu autoram, savukārt, šḳiet, ka abas vēlmes nav savietojamas, Krievija nepiekritīs "normāli tirgoties", atsakoties no politiskām interesēm un prasībām. Pat pirmskara periodā PSRS ekonomiskā politika pret Latviju bija tikai tās politiskās spēles sastāvdaḷa. ${ }^{4}$ G. Reire norāda, ka Krievijas lēmumiem ekonomiskajā jomā ir "politisks un stratēgisks raksturs" (293. lpp.). Tādos apstākḷıs arī rūpīgi gatavotajām Valsts prezidentu vizītēm Maskavā 2005. un 2010. gadā nebija raksturīgi ekonomiski un politiski ieguvumi. Runājot par nākotni un kopumā, autore secina, ka arī Rietumi ir dzīvojuši zināmā pašapmānā attiecībās ar Krieviju, būdami nepamatoti optimistiski par nākotni (303. lpp.).

Vēstnieks Eduards Stiprais nodaḷā par Eiropas integrāciju atzīmēe, ka tas bijis viņa dzīves lielākais piedzīvojums. Arī viņš noraida citas iespējamās ārpolitiskās izvēles kā nepamatotas, kaut arī Baltijas valstis tika uzskatītas par otrškirīgām salīdzinājumā ar Centrāleiropas valstīm un tās nebija "lielvalstu politikas radaros" (185.-187. lpp.). Tomēr Latvijas ārpolitikas konsekventais kurss, kuram izdevās radīt zināmu iekšpolitisku konsensu un kuru spēcīgi atbalstīja Ziemel̦valstis, nozīmēja lūzumu un pakāpeniskus panākumus. Iestāšanās sarunas Eiropas Savienībā bija nopietns pārbaudījums ārpolitiskā dienesta kapacitātei (kompetence, svešvalodu zināšanas, Eiropas tiesību integrācija), kā arī visas valsts pārvaldes kapacitātei. Zināma nozìme bija arī geopolitiskajiem aspektiem, lai gan to loma varēja būt pat lielāka, kā piesardzīgi atzīst E. Stiprais.

Vairākas esejas veltītas mazāk zināmiem jautājumiem. Ingrīda Levrence raksta par attiecībām ar jaunajām neatkarīgajām valstīm, kas izveidojās pēc PSRS sabrukuma, un Kinnas Tautas Republiku 
(307.-326. lpp.). Varbūt šāds tvērums ir pārāk plašs, n,emot vērā Ķīnas milzīgo nozīmi mūsdienu pasaules politikā. Sandra Kalniete pievērsusies neatkarības starptautiskās atzīšanas unikālajam procesam (101.-115. lpp.), konstatējot, ka tā sauktās lienošās atzišanas process bija unikāls diplomātijas vēsturē. Mārtinš̌ Virsis, rakstot par neatkarības atjaunošanas diplomātiskajiem aspektiem, norāda, ka starptautiskās tiesības, uz kurām balstījās Baltijas valstu neatkarības atjaunošana, ir atkarīgas no valstu "gatavïbas un apñēmības [...] tās aizstāvēt un istenot dzìve" (124. lpp.). Šì principa izpratne kḷuva ippaši svarīga neatkarības atjaunošanas periodā, un par to nevajadzētu aizmirst arī tagad.

Daudzām esejām pievienots literatūras saraksts vai atsauces, kas arī liecina par grāmatas vērtību. Pats par sevi saprotams, ka tās kḷūs par Latvijas diplomātijas vēstures avotiem, kas atspogul,o ne tikai faktus, bet arī konceptuālu izpratni par Latvijas ārpolitikas problēmām. Rezumējot jāatzīmē, ka Ârlietu ministrijas publicistisko darbību būtu vērts turpināt.

\section{ATSAUCES UN SKAIDROJUMI}

${ }^{1}$ KRISTĪNE KOZlOVA (sast.). Atgriešanās Eiropā Latvijas prezidentu, premjerministru, ministru un diplomātu esejās: no starptautiskās atzīšanas līdz pirmajai prezidentūrai Eiropas Savienībā, 1990-2015. Rīga 2016. Pieejams: https://dom.lndb.lv/data/obj/file/305363

${ }^{2}$ Aivars StrangA. Latvijas - padomju Krievijas miera līgums 1920. gada 11. augustā: Latvijas padomju Krievijas attiecības 1919.-1925. gadā. Rīga 2000, 227. lpp.

${ }^{3}$ Sanita Jemberga, Pauls Raudseps, Gunta Sloga. VVF. Prezidentes Vairas Vīkses-Freibergas politiskā biogrāfija. Rīga 2008, 164. lpp.

${ }^{4}$ StRANGA, Latvijas - padomju Krievijas miera līgums 1920. gada 11. augustā, 216.-224. lpp. et al. 


\section{Ziṇas par autoriem}

About Authors 



\section{Ziṇas par autoriem / About Authors}

Dāvis Beitlers (1993) ir vēstures maǵistrs (LU, 2017), Rīgas vēstures un kuǵniecības muzeja Latvijas kuǵniecības vēstures nodaḷas vēsturnieks, vairāku zinātnisku un populārzinātnisku grāmatu autors vai redaktors, Latvijas Universitātes doktorants; izstrādā promocijas darbu par tēmu, kas saistīta ar latviešu tautsaimniecību trimdā. Zinātniskās intereses: latviešu trimdas vēsture, Latvijas jūrniecības vēsture, Latvijas grāmatniecības vēsture, Latvijas ērǵeḷmākslas (instrumenti, mūzika un mūziḳi) vēsture, reǵionālās vēstures izpētes problēmas, historiogrāfija.

Dāvis Beitlers (1993) holds a MA degree in history (University of Latvia, 2017). He is a historian at the Museum of the History of Riga and Navigation (Department of the History of Latvian Navigation), an author or editor of several scientific and popular science books, doctoral student in history at the University of Latvia; working on the $\mathrm{PhD}$ thesis dedicated to Latvian economic activities in exile. Research interests include history of Latvian exile, Latvian navigation, Latvian book production, Latvian organ culture (musical instruments, music, musicians), and the research problems of regional (local) history, historiography.

Raimonds Cerūzis (1972) ir Latvijas Universitātes Vēstures un filozofijas fakultātes Vēstures un arheoloǵijas nodaḷas asociētais profesors, vadošais pētnieks. Vēstures doktora grādu ieguvis 2003. gadā Latvijas Universitātē. Bijis starptautisko norišu komentētājs Latvijas Radio, kā arī galvenais redaktors un autors Latvijas Institūta izdotajiem valsts atpazīstamību ārzemēs veicinošiem informatīviem materiāliem. Daudzu zinātnisku publikāciju autors par vācbaltiešu vēsturi Latvijas teritorijā. Zinātniskās intereses: vācu zemju un Vācijas vēsture, vācu ietekme Latvijas teritorijas vēsturē, nacionālo minoritāšu vēsture, Baltijas vēsture, ideologijiju vēsture 19. un 20. gadsimtā.

Raimonds Cerūzis (1972) is an associate professor at the Department of History and Archaeology, the Faculty of History and Philosophy, University of Latvia. Doctor of history (University of Latvia, 2003). Previously was a columnist of the international affairs at the Latvian Radio (Latvijas Radio), chief editor and author of books and articles at the Latvian Institute - the institution promoting knowledge about Latvia abroad. Author of many publications about the history of Baltic Germans (Deutschbalten). Research interests include the history of Germany, the influence of Germans on the history of Latvia, history of national minorities, history of the Baltic region, history of ideologies in the $19^{\text {th }}$ and $20^{\text {th }}$ centuries.

Ēriks Jēkabsons (1965) ir Latvijas Universitātes Vēstures un filozofijas fakultātes Vēstures un arheolog̣ijas nodaḷas profesors. Vēstures doktors (LU, 1995). Latvijas Zinātṇu akadēmijas īstenais loceklis. 27 grāmatu (piecas no tām izdotas ārvalstīs) un 260 zinātnisku rakstu (apmēram puse no tiem publicēti 13 ārvalstīs) autors. Piedalījies 210 zinātniskās konferencēs. Latvijas Zinātnes padomes eksperts, Polijas un Rumānijas Nacionālās zinātnes padomes 
ārzemju eksperts, piecu Latvijas un 17 ārvalstu zinātnisko žurnālu redkolēgiju loceklis. Viesprofesors Polijas un Ukrainas universitātēs. Apbalvots ar Polijas Zelta Nopelnu krustu un III šķiras Triju Zvaigžņu ordeni. Zinātniskās intereses: Latvijas un reǵiona politiskā un militārā vēsture 20. gadsimta pirmajā pusē.

Ėriks Jēkabsons (1965) is a professor at the Department of History and Archaeology, Faculty of History and Philosophy, University of Latvia. Doctor of History (University of Latvia, 1995). A full member of the LAS. An author of 27 books (5 of these published abroad) and 260 scientific articles (about a half of them published in 13 countries), he has taken part in 210 scientific conferences, served as an expert at the Latvian Scientific Council, a foreign expert of Polish, Romanian National Scientific Councils. He is a member of editorial board of 5 Latvian and 17 foreign scientific journals, a visiting professor at universities in Poland and Ukraine. Decorated with Poland's Gold Merit Cross. A Commander of the Order of the Three Stars. Research interests include political and military history of Latvia and the region in the first half of the $20^{\text {th }}$ century.

Jurijs Sḷozkins (1956) ir Amerikas Mākslu un zinātṇu akadēmijas loceklis, Kalifornijas Universitātes (Bērkli, ASV) profesors, vadošais pētnieks Oksfordas Universitātes Sv. Edmunda koledžā, Krievijas prezidenta Krievijas Tautsaimniecības un valsts dienesta akadēmijas vecākais pētnieks. Vairāku grāmatu autors: "Ebreju gadsimts" (angḷu val.) (Prinstona, 2004), "Valdības māja: Krievu revolūcijas sāga" (angḷu val.) (Prinstona, 2017) u. c.

Yuri Slezkine (1956) is a member of the American Academy of Arts and Sciences; Professor of the Graduate School at the University of California, Berkeley; Senior Research Fellow at St. Edmund Hall, University of Oxford; and Senior Research Associate at the Russian Presidential Academy of National Economy and Public Administration. His books include "The Jewish Century" (Princeton, 2004) and "The House of Government: A Saga of the Russian Revolution" (Princeton, 2017) etc.

Vija Stikāne (1970) ir vēstures doktore (LU, 2012), Turaidas muzejrezervāta direktores vietniece zinātniskajā darbā. Promocijas darbs - "Sieviete Livonijas sabiedrībā viduslaikos un jauno laiku sākumā 13.-16. gs.”. Zinātniskās intereses: Livonijas sociālā vēsture viduslaikos un agro jauno laiku sākumā, Rīgas arhibīskapijas pārvaldes vēsture 13.-16. gadsimtā, Turaidas vēsturiskā centra mantojums, pētnieciskais darbs muzejā.

Vija Stikāne (1970) is a Doctor of History (University of Latvia, 2012), deputy director of scientific work at Turaida Museum Reserve. Her PhD thesis title is "Woman in Medieval and Early Modern Livonia from the $13^{\text {th }}$ to $16^{\text {th }}$ century". Research interests include society of Livonia in the medieval and early modern period, administration of Archbishopric of Riga from the $13^{\text {th }}$ to $16^{\text {th }}$ century, heritage of the historic centre of Turaida, scientific work in museums.

Jānis Taurēns (1969) ir Latvijas Universitātes Vēstures un arheologiijas nodaḷas asociētais profesors. Vēstures doktors (LU, 1999). Žurnāla "Latvijas Universitātes Žurnāls. Vēsture" galvenais redaktors. Monogrāfiju "Latvijas ārpolitika un diplomātija 20. gadsimtā" (Rīga, 
2015-2016) un “15. maija Latvija” (Rīga, 2017) līdzautors. Zinātniskās intereses: Latvijas ārpolitikas vēsture, Latvijas politiskā vēsture kopš neatkarības atjaunošanas, Latvijas vēstures historiogrāfija.

Jānis Taurēns (1969) is an associate professor at the Department of Archaeology, the Faculty of History and Philosophy, the University of Latvia. Doctor of History (University of Latvia, 1999). General editor of the periodical "History. Journal of the University of Latvia". Co-author of the collective monographs "Foreign policy and diplomacy of Latvia in the $20^{\text {th }}$ century" (Rìga, 2015-2016, in Latvian) and Latvia of May 15 (Rìga, 2017, in Latvian). Research interests include history of Latvia's foreign policy, political history of Latvia since restoration of independence, historiography of Latvian history.

Edmunds Trumpa (1968) ir Latvijas Universitātes Humanitāro zinātṇu fakultātes Latvistikas un baltistikas nodaḷas asociētais profesors. LU Lituānistikas centra vadītājs. Humanitāro zinātṇu doktors filolog̣ijā (Lietuviešu valodas institūts, Vītauta Dižā Universitāte, 1995). Divu monogrāfiju un vairāku rakstu autors, četru grāmatu līdzautors. Piedalījies 80 zinātniskās konferencēs. Zinātniskās intereses: baltu valodu fonolog̣ija, dialektolog̣ija, baltu valodu vēsture, lietuviešu literatūras un kultūras vēsture.

Edmundas Trumpa (1968) is an associate professor at the Department of Latvian and Baltic Studies, Faculty of Humanities, University of Latvia. Head of the Lithuanian Studies Center at the UL. PhD degree holder (Institute of the Lithuanian Language, Vytautas Magnus University, 1995). An author of 2 monographs and several articles, co-author of 4 books. He has taken part in 80 scientific conferences. Research interests include phonology and dialectology of the Baltic languages, history of the Baltic languages, history of Lithuanian literature and culture.

Ilze Vaivode (1996) ir vēstures mağistre (LU, 2020). Mağistra darba tēma - "Latvijas tūrisma un ekskursiju pārvaldes (Latvijas republikāniskās tūrisma padomes) darbība 20. gadsimta 60. gados". Pētnieciskās intereses: Latvijas padomju okupācijas perioda vēsture.

Ilze Vaivode (1996) holds a MA degree in history (University of Latvia, 2020). The title of her master's thesis is "The Activity of the Administration of Tourism and Excursions of Latvia (Republican Tourism Council of Latvia) in the 1960s". Research interests include the history of the Soviet occupation period in Latvia.

Eginhards Volāns (1992) ir vēstures mag̣istrs (LU, 2018). Maǵistra darba tēma - "LatvijasKrievijas 1998. gada attiecību krīze: cēloṇi un norise”. Pētnieciskās intereses: Latvijas un Krievijas attiecības un Latvijas politiskie procesi pēc PSRS sabrukuma.

Eginhards Volāns (1992) holds a MA degree in history (University of Latvia, 2018). The title of his master's thesis is "Crisis of 1998 in Latvian-Russian relations: causes and conduct". Research interests include Latvian-Russian relations and political processes in Latvia after the collapse of the USSR. 
Izdevējs: LU Akadēmiskais apgāds

Aspazijas bulv. 5-132, Rīga, LV-1050

www.apgads.lu.lv

Iespiests SIA "Latgales druka" 